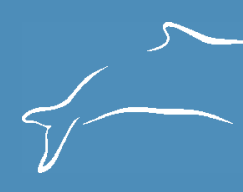

\title{
A review of marine mammal records of Cuba
}

\section{Article Info}

\begin{tabular}{|c|c|}
\hline Manuscript type & Review \\
\hline \multicolumn{2}{|l|}{ Article history } \\
\hline Received & 06 January 2012 \\
\hline Received in revised form & 16 March 2012 \\
\hline Accepted & 02 April 2012 \\
\hline Available online & 27 January 2014 \\
\hline \multicolumn{2}{|c|}{$\begin{array}{l}\text { Keywords: Caribbean Sea, Cuban EEZ, occurrence, } \\
\text { distribution, cetacean, pinniped, sirenian }\end{array}$} \\
\hline \multicolumn{2}{|c|}{ Responsible Editor: Daniel M. Palacios } \\
\hline \multicolumn{2}{|c|}{$\begin{array}{l}\text { Citation: Whitt, A.D., Jefferson, T.A., Blanco, M., Fertl, D., } \\
\text { and Rees, D. (2011) A review of marine mammal records of } \\
\text { Cuba. Latin American Journal of Aquatic Mammals 9(2): 65-122. } \\
\text { http://dx.doi.org/10.5597/lajam00175 }\end{array}$} \\
\hline
\end{tabular}

\section{Amy D. Whitt ${ }^{\dagger,}$, Thomas A. Jefferson ${ }^{\ddagger}$, Miriam Blanco $\$$, Dagmar Fertl ${ }^{\S}$ and Deanna Rees ${ }^{\#}$}

Geo-Marine, Inc., 2201 K. Avenue, Suite A2, Plano, TX 75074, USA ‡Clymene Enterprises, 13037 Yerba Valley Way, Lakeside, CA 92040, USA ${ }^{\S}$ Acuario Nacional de Cuba, Avenida $1^{\text {ra }}$ y 60, Playa, CP 11300, Habana, Cuba

'Ziphius EcoServices, 8112 Springmoss Drive, Plano, TX 75025, USA

${ }^{\#}$ Naval Facilities Engineering Command, Atlantic Division, 6506 Hampton Boulevard, Norfolk, VA 23508-1278, USA

*Corresponding author, e-mail: adwhitt@gmail.com

Abstract: There has been very little research on marine mammals in Cuban waters. Much of the information on marine mammals in this region is buried in historical and gray literature. In order to provide a comprehensive account of marine mammal occurrence in Cuba's Exclusive Economic Zone (EEZ), we reviewed and verified 659 published and unpublished sighting, stranding, capture, and tagging records. Eighteen extant species and four genera have confirmed records for Cuban EEZ waters. This includes 17 species of cetaceans (three baleen whales and 14 toothed whales) and one sirenian species. An additional 11 cetacean species and one extant pinniped species have been reported, but not confirmed, or may have the potential to occur in Cuban waters. Historical records of the Caribbean monk seal (Monachus tropicalis) are documented in Cuba; however, this species is now considered extinct. The only two species that are seen regularly and considered common in Cuban nearshore waters are the common bottlenose dolphin (Tursiops truncatus) and the West Indian manatee (Trichechus manatus).

Resumen: No hay mucha investigación sobre el tema de los mamíferos marinos en aguas cubanas. La mayoría de la información se encuentra enterrada en la literatura histórica y gris. A fin de proporcionar un informe completo de la presencia de mamíferos marinos en la Zona Económica Exclusiva (ZEE) de Cuba, hemos revisado y verificado 659 registros publicados y no publicados de avistamientos, varamientos, capturas y marcajes. Dieciocho especies existentes y cuatro géneros tienen registros confirmados para las aguas de la ZEE cubana. Esto incluye 17 especies de cetáceos (tres ballenas barbadas y 14 odontocetos) y una especie de sirenio. También se han reportado sin confirmar, o tienen el potencial de presentarse en aguas cubanas, 11 especies de cetáceos y una especie de pinnípedo. Existen registros históricos de la foca monje del Caribe (Monachus tropicalis) en Cuba, sin embargo esta especie se considera extinta. Las únicas dos especies que se ven regularmente y se consideran comunes en las aguas costeras de Cuba son el tursión (Tursiops truncatus) y el manatí antillano (Trichechus manatus). 


\section{Introduccion}

Marine mammal occurrence is not well documented for Cuban waters. Although historical accounts are summarized in the older literature (e.g. Cuní, 1918; Aguayo, 1954), no recent comprehensive account of marine mammals of Cuba exists. Most records are based on historical accounts and gray literature; therefore, verification of records is often difficult. Very few surveys of marine mammals have been conducted in this region of the Caribbean Sea. Most of what is known about marine mammals in Cuban waters comes from stranding and/ or capture information from local fishermen. Although these types of records are useful for identifying species presence, they do not provide adequate information on species abundance and distribution which can be estimated from systematic surveys. Abundance information is particularly important for determining population trends. One species that is known to have undergone a decline in Cuban waters is the West Indian manatee (Trichechus manatus). The Cuban manatee population decreased dramatically in the late 1800 s due to a targeted fishery (Cuní, 1918). Captures of manatees are now prohibited in Cuba. However, Cuba maintains a direct livecapture fishery for common bottlenose dolphins (Tursiops truncatus) via annual quotas which are assigned to dolphinaria of various countries within the regulations established by the Convention on the International Trade in Endangered Species of Wild Flora and Fauna (CITES) (Espinosa and Orta 2007). To provide a comprehensive account of marine mammals of Cuba, we reviewed all available records of marine mammals in Cuba's EEZ waters. This paper includes a summary of 659 available records through December 2008 and recommendations for future research efforts.

\section{Materials and Methods \\ Study Area}

The Study Area consists of the EEZ waters surrounding the mainland of Cuba and an archipelago of more than 3,000 small islands or keys (GDAIS 2004) (Figure 1). Cuba is surrounded by deep basins and trenches of the Caribbean Sea, Gulf of Mexico, the Straits of Florida, and The Bahamas (e.g. Old Bahama Channel, Windward Passage, Yucatán Channel, and Cayman Trench) (Figure 1). The Cuban platform can be divided into four wide-shelf areas, two on the north side (Sabana-Camagüey and Los Colorados Archipelagos) and two on the south side (Golfo de Batabanó and the area including Golfo de Ana María and Golfo de Guacanayabo). These wide-shelf areas are separated by narrow shelves (Claro et al., 2002). Cuba has extensive seagrass beds within the coastline's substantial shelf and shallow waters. Where the insular shelf is narrow, deep waters are found within a few kilometers $(\mathrm{km})$ of land.

Cuban waters are directly influenced by the Loop, Yucatán, and Florida Currents. Circulation patterns off northwestern Cuba are highly dependent on prevailing winds due to the shallow depths, while circulation off the north-central coast

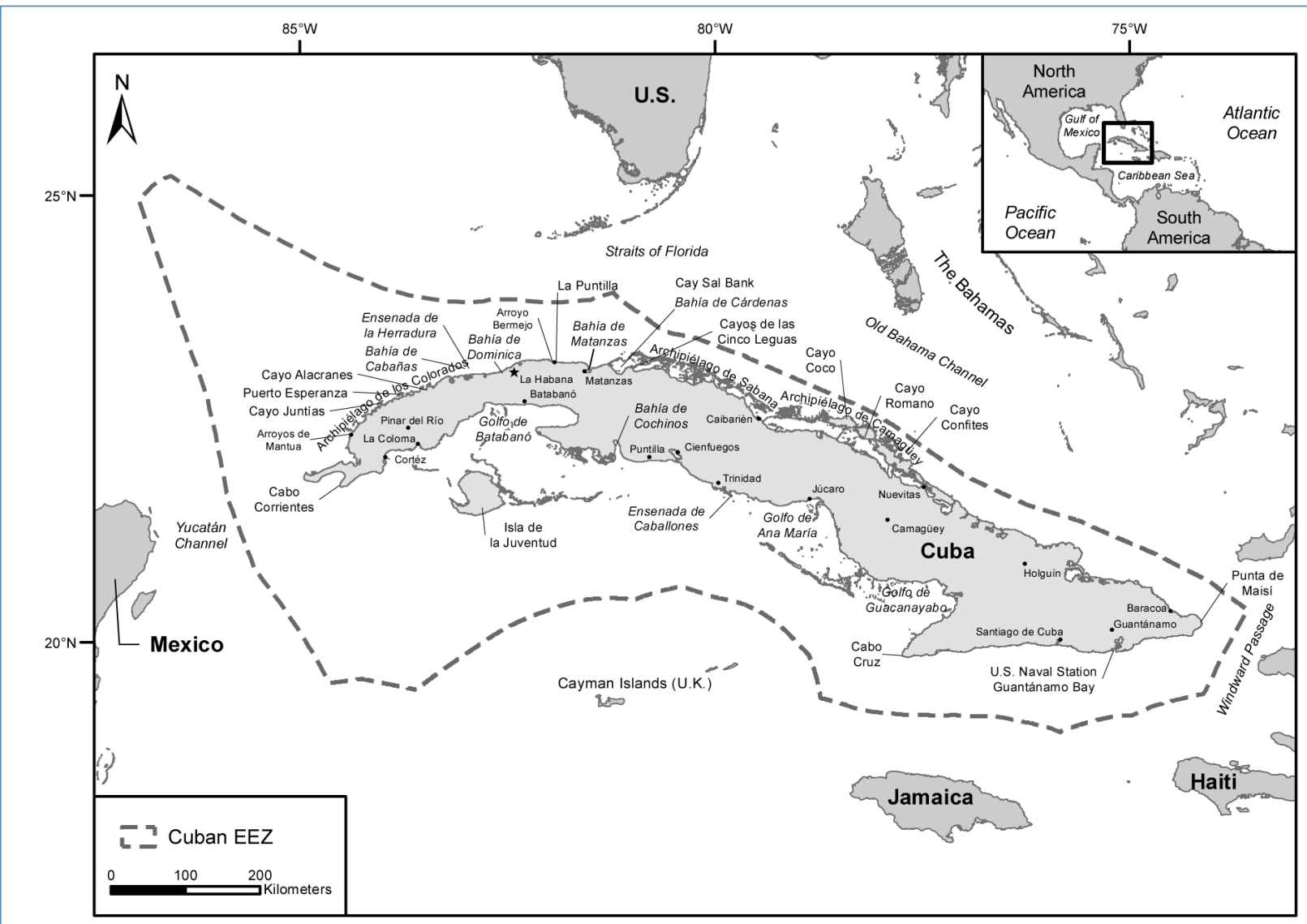

Figure 1. The Study Area which includes waters of the Cuban EEZ. 
is determined mainly by tidal currents. The southern coast of Cuba is influenced by a diverse system of eddies (Claro et al., 2002).

\section{Sources of Data}

We collected and assessed all available published and unpublished sighting, stranding, capture (including direct captures and bycatch records), and tagging records for marine mammals in Cuban EEZ waters through December 2008. In some cases, species' records were only available for waters directly outside of the EEZ. To provide the most complete account of each species, we discuss records in the near vicinity of the Cuban EEZ; however, these records are not included in the figures or appendix. Records located on the border of the EEZ were treated as occurring within the EEZ. A total of 659 records were compiled from a variety of sources. Some of the primary data sources are summarized below.

Published literature - A search of peer-reviewed and nonpeer-reviewed literature uncovered several historical accounts of marine mammal occurrence in Cuban waters. For example, Cuní (1918) provided one of the first reviews about cetaceans captured near the Cuban coast and also included information on cetacean strandings and skeletons found in Cuba. Aguayo (1954) discussed sightings of several cetacean species in Cuban waters and provided general descriptions of other marine mammal species known to occur in Cuban waters. Alayo (1958) listed marine mammal species of Cuba but did not provide specific information on records. Varona (1973) summarized marine mammal records of Cuba but provided general location information instead of specific records of occurrence. Information on historical whaling catches near Cuba is summarized in Townsend (1935) based on whaling logbooks. Historical sighting records of unidentified cetaceans were collected from Coast Guard reports via the Cetacean and Turtle Assessment Program (CETAP 1982) ${ }^{1}$. Some of the most extensive studies of marine mammals in Cuba have been conducted by researchers from the Acuario Nacional de Cuba (e.g. Blanco and Olaechea, 1996; Pérez-Cao, 2004; Perez-Cao et al., 2009; López et al., in press). These studies have focused on collecting morphometric data and relative abundance and distribution information on common bottlenose dolphins along the northern coast of Cuba. Other records of marine mammals in Cuba are scattered throughout the literature.

United States (U.S.) Navy-The U.S. Navy has recorded opportunistic sightings of marine mammals (predominantly West Indian manatees) at U.S. Naval Station Guantánamo Bay (GTMO) since 1996. Base Natural Resources Managers encourage Base residents to report all sightings of this species ${ }^{2}$. Opportunistic sightings are generically provided by pleasure boaters, fishermen, and recreational divers. Aerial, boat, and shore-based surveys were conducted by Base personnel

${ }^{1}$ Kenney, R., University of Rhode Island, pers. comm., 22 July 2009.

${ }^{2}$ Howe, B., U.S. Navy, pers. comm., 24 August 2000. and volunteers from 1999 through 2003 on an irregular basis (approximately five times per year). These surveys were completed using the protocols described in Roca and Sedaghatkish (1998) and the GTMO (1996) for manatees ${ }^{3}$. Survey and opportunistic data collected at GTMO between July 1996 and January 2008 are included in this paper.

National Marine Fisheries Service (NMFS)_The NMFSSoutheast Fisheries Science Center (SEFSC) Pelagic Observer Program (POP), which monitors the mobile U.S. pelagic longline fleet, has collected marine mammal bycatch data for the east coast of Cuba. Most of these records are of unidentified cetacean species (e.g. Garrison and Richards, 2004; NMFS-SEFSC 2004). Several NMFS survey vessels have transited Cuban waters while en route to other areas of the Caribbean but did not collect data on marine mammals due to the lack of Cuban research permits (e.g. Swartz and Burks, 2000; Fulling and Clapham, 2004).

Other opportunistic sources-Several records of marine mammals in Cuban waters were obtained from personal accounts and observations. In addition, unpublished data from Hal Whitehead (Dalhousie University) are included in this paper. No specific survey information was available, but the sperm whale (Physeter macrocephalus) vocalization study for which these data were collected was described in Rendell and Whitehead (2003). Additional opportunistic sightings were recorded on oceanographic surveys in the southern Gulf of Mexico and the Yucatán Channel in March 1998 (OrtegaOrtiz, 2002) and on the U.S. Training Ship Texas Clipper in June 1991 (Jefferson and Lynn, 1994). Satellite-tagging data were obtained from the U.S. Minerals Management Service's Sperm Whale Seismic Study (SWSS) which was conducted during the summers between 2002 and 2005 in the Gulf of Mexico (Jochens et al., 2008). Tracking data were also obtained from post-release monitoring of rough-toothed dolphins (Steno bredanensis) released after a mass stranding in the Florida Keys (Wells et al., 2008).

Museum holdings-The U.S. National MuseumSmithsonian Institution National Museum of Natural History provided records of marine mammals in Cuban waters. None of the authors of this paper were able to travel throughout Cuba to assess local museum holdings of marine mammal specimens. All information on museum holdings was provided from literature or personal communications from colleagues. We were not able to confirm the locations of several specimens that are mentioned throughout this paper; however, we have included the locations of where certain specimens were thought to occur. It is possible that these locations will be able to be verified in the future. The following museums/institutions currently or have previously housed marine mammal specimens: Instituto de Biología, Museo Nacional de Historia Natural (formerly known as the Felipe Poey Museum), Instituto of Oceanología, Colegio de

${ }^{3}$ Howe, B., U.S. Navy, pers. comm., 17 April 2006. 
Belén, Instituto de Ecología y Sistemática, Museo Nacional de Historia Natural de Cuba, Academia de Ciencias Médicas, Físicas y Naturales, Museo Natural de Guanabo, and the Museo de Historia Natural de Santiago de Cuba (Tomás Romay Museum). Several specimens from the Tomás Romay Museum are included in this paper and were verified from photographs. The Felipe Poey collection was transferred to the Universidad de La Habana several years ago. Several whale and manatee specimens are currently on public display in the Science Building . The Colegio de Belén is now the Instituto Técnico Militar (Military Technical Institute) in Habana. The Instituto de Ecología y Sistemática collection contains historical materials from Juan Gundlach and more recent specimens; it is unknown if marine mammal specimens are included in this collection ${ }^{4}$. The Museo Nacional de Historia Natural de Cuba is now in the former U.S. Embassy in Habana Vieja on Calle Obispo and contains several marine mammal specimens which could not be verified at this time ${ }^{4}$.

Unavailable data-With assistance from the Wildlife Trust, the Centro de Investigaciones Marinas has conducted aerial surveys and radio-telemetry studies of West Indian manatees in Cuban waters; however, none of these data have been published or were available for inclusion in this paper ${ }^{5}$. Additional manatee aerial surveys were flown over parts of southern Cuba between the mid-1980s and early 1990s. Results of these studies are discussed in the text of this paper, but the data could not be obtained.

\section{Verification of Records}

The following criteria were used to verify species identification of each record collected: photos or video showing diagnostic characters, drawings or detailed descriptions of diagnostic characters, skull or other voucher specimen showing diagnostic characters, or observations from reliable marine mammal experts. Criteria were not as stringent for easily recognizable species, such as the West Indian manatee, since a relatively inexperienced observer can typically identify this species correctly. Attempts were made to confirm all available records; however, many of the records could not be confirmed due to lack of proper documentation. Historical records, in particular, often did not include enough information to accurately verify the identification of a marine mammal to the species level. A designation of 'possible' or 'doubtful' was assigned to these questionable records based on the quality of available information. Errors in some of the original designations are discussed in the results section of this paper. Records from fishermen were designated as 'possible' instead of 'confirmed' due to the unreliable nature of observations from non-experts. All records found for marine mammals in the Study Area are listed in the appendix.

\footnotetext{
${ }^{4}$ Wiley, J., University of Maryland Eastern Shore, pers. comm., 5 April 2009.

${ }^{5}$ Álvarez Alemán, A., Centro de Investigaciones Marinas, pers. comm., 25 April 2008.
}

Some confirmed records located outside the Study Area are discussed in the appropriate species sections in order to provide a review of pertinent distribution information for those species that do not have any records within the EEZ but which are known to occur nearby. We also discuss species which have unverified records in close proximity to Cuba and assess the potential for their occurrence in the EEZ to help provide an accurate list of species that may be expected in Cuban waters. In addition, possible and doubtful records are discussed for species not thought to occur in the EEZ to provide a thorough assessment, particularly since many of these records are listed as confirmed in the literature.

\section{Mapping of Records}

Marine mammal records were accumulated from every available source; however, it was impossible to obtain every data source in existence for Cuba. To organize and store the available data, a master database was created in Microsoft ${ }^{\oplus}$ Access. The data format was standardized so that all the data could be merged and later used in a Geographic Information System (GIS). A GIS was used to store, manipulate, analyze, and display the spatial data and information of the records collected. Environmental Systems Research Institute, Inc.'s (ESRI) ArcView ${ }^{\bullet}$ version 9.2 GIS software was used to create the map figures. The latitude and longitude of each record was converted to decimal degrees, and the Mercator map projection was used for all figures.

Many records accumulated during our data search and collection process included geographical data points (latitude and longitude). For the records without geographical coordinates, latitude and longitude were estimated from given location descriptions when possible. For instance, many of the records for the Guantánamo Bay region did not include specific locations or coordinates. These records were plotted based on general locations, and the points were shifted on the maps so that each overlapping record is visible. Several records did not include coordinates or specific location descriptions and could not be plotted. Figures of common bottlenose dolphin sightings from PérezCao (2004) and Alvarez Alemán et al. (2009) were digitized and geo-referenced into a GIS.

All sighting, stranding, capture, and tagging records were plotted regardless of their confirmation status. Capture records included bycatch, whaling, and other intentional captures while strandings include live or dead animals as well as osteological records. Group sizes are not depicted in the figures; however, group sizes are included in the appendix when known. Map figures were created for the following species and groups: large whales (Figure 2), Kogiidae (Figure 3), beaked whales (Figure 4), Delphinidae (Figure 5), common bottlenose dolphin (Figure 6), Stenella (Figure 7), West Indian manatee (Figure 8), and Caribbean monk seal (Figure 9). The data sources for the records plotted in these figures are included in the appendix. 


\section{Results}

A total of 659 records of marine mammals were compiled. Eighteen extant species and four genera have confirmed records for Cuban waters. This includes 17 species of cetaceans (three baleen whales and 14 toothed whales), one species of sirenian, and one extinct species of pinniped. An additional 11 cetacean species and one extant pinniped species have been reported, but not confirmed, or may have the potential to occur in Cuban waters based on known distributions of the species in the Caribbean Sea (Table 1). Of the 659 total records, 612 were confirmed, 36 were designated as possible, and 11 were designated as doubtful. All records are listed in the appendix and discussed below in taxonomic order.

\section{LARGE WHALES}

\section{North Atlantic right whale, Eubalaena glacialis}

In the western North Atlantic, North Atlantic right whales are primarily found between Florida and Nova Scotia (Winn et al., 1986). They are distributed on feeding grounds off the northeastern U.S. and Canada during the spring through early summer. During the winter (as early as November and through April), North Atlantic right whales are primarily found in coastal waters off North Carolina, Georgia, and northern Florida (Winn et al., 1986; Kenney, 2001; Firestone et al., 2008) but also occur throughout the mid-Atlantic and northeastern U.S. (Knowlton et al., 2002; Mellinger et al., 2007; NOAA Fisheries Service, 2008).

Right whales are not known to occur in the Caribbean Sea; there are no records of this species in Cuban waters. However, individuals (including cow-calf pairs) are documented on rare occasions during winter and spring in the Gulf of Mexico as far west as Texas. These occurrences are considered outside the normal range of this species (Moore and Clark, 1963; Schmidly et al., 1972; Jefferson and Schiro, 1997; Anonymous, 2006). Sightings are also recorded year-round off the southeastern U.S. Atlantic coast (Winn et al., 1986). Based on the confirmed records of this species in the Gulf of Mexico, extralimital sightings of North Atlantic right whales off the coast of Cuba are possible.

\section{Humpback whale, Megaptera novaeangliae}

In the North Atlantic Ocean, humpback whales are found from spring through fall on feeding grounds south of New England to northern Norway (Whitehead, 1982; Kenney and Winn, 1986; Weinrich et al., 1997; Stevick et al., 2003). During winter, most of the North Atlantic population is believed to migrate south to calving grounds in the West Indies (Winn et al., 1975; Whitehead and Moore, 1982; Stevick et al., 1998; Smith et al., 1999). Most humpbacks are found in this region from January through March, with some animals arriving as early as November and a few remaining in the area until June (Erdman et al., 1973; Winn et al., 1975; Katona and Beard, 1991; Reeves et al., 2001). Humpback whales in the northeastern Caribbean Sea are primarily found off the northern coast of the Dominican Republic on Silver and Navidad Banks (Winn et al., 1975; Mattila et al., 1989) and in Samana Bay (Mattila et al., 1994), as well as on the Virgin and Anguilla Banks of the eastern Leeward Islands (Mattila and Clapham, 1989) and in the Mona Passage off western Puerto Rico (Mignucci-Giannoni, 1998; Sanders et al., 2005).

Townsend (1935) identified the Caribbean as a former humpback whaling ground. Based on logbook records, several humpback whales were taken off the northern coast of Cuba sometime between 1752 and 1902 (Townsend, 1935). Townsend mapped the locations of active whaling ships but did not provide coordinates or additional information for the humpback whale captures. Reeves et al. (2001) noted inconsistencies within logbooks which did not include information on presence or absence of humpbacks in Cuban waters. Schmidly (1981) estimated the coordinates from the Townsend charts; these coordinates place humpback whale captures just north of the Cuban EEZ in the Straits of Florida. No additional information, such as number of whales taken or exact dates of the takes, were provided in Schmidly (1981) or Townsend (1935).

Humpback whales may occur in Cuban waters during the breeding season (particularly November through June) but are not as likely to occur there during summer (July through September) when they are primarily on feeding grounds from south of New England to northern Norway. Humpback whales have been recorded along the coast of Cuba and around the smaller islands of Cuba. One sighting is confirmed during winter; this humpback whale was recorded in January 1999 near Boca de Jaruco, east of Habana, for six days before it died (Figure 2) ${ }^{6,7}$. Bones of this stranded individual are supposedly housed at the Museo Natural de Guanabo $(25 \mathrm{~km}$ east of Habana). Other possible winter records include the following: a sighting along the shoreline of Habana in December 2004 (Blanco, 2008) $^{8}$; a sighting off Punta Seboruco, Matanzas in January 2005 (Blanco, 2008) ${ }^{8}$; a stranding in Cayo Coco on the northern coast of Cuba in February 2000 (Figure 2) (the whale may have been harpooned offshore before it stranded in Cayo Coco) (González et al., 2001); and a sighting 20 miles $(37 \mathrm{~km}$ ) off Habana in December 1932 (Aguayo, 1954) (Figure 2). Würsig et al. (2000) incorrectly recorded this sighting as a stranding 7 nautical miles (NM) $(12.4 \mathrm{~km})$ from Habana.

Other records of this species in Cuban waters during the breeding season include a sighting of two individuals confirmed off Baracoa in March 20089 ; a possible sighting of

\footnotetext{
${ }^{6}$ Humpback whale dies off Cuban coast. Accessed 1 December 2008. http://www.radiohc.org/Distributions/Radio_Havana_English/.1999/99_ jan/rhc-eng-01.20.99.

${ }^{7}$ Blanco, M., pers. obs., 13 January 1999.

${ }^{8}$ Yánez, A., Patrón del Catamarán de Turismo DODY, pers. comm., February 2005 .

${ }^{9}$ Ballenas frente a las costas de Baracoa. 201 Lecturas by Soler Costafreda, A. Accessed 13 March 2008. www.portal.jovenclub.cu.
} 
Table 1. Marine mammal species/groups with confirmed and possible occurrence in Cuban EEZ waters and their status under the International Union for Conservation of Nature (IUCN, 2011). Naming convention of cetaceans follows the approved International Whaling Convention (IWC) listing; naming convention of all other species follows Rice (1998).

\begin{tabular}{|c|c|c|}
\hline Common Name & Scientific Name & IUCN Status \\
\hline \multicolumn{3}{|c|}{ CONFIRMED OCCURRENCE } \\
\hline Humpback whale & Megaptera novaeangliae & Least Concern \\
\hline Fin whale & Balaenoptera physalus & Endangered \\
\hline Bryde's whale & Balaenoptera edeni $i^{\mathrm{a}}$ & Data Deficient \\
\hline Unidentified balaenopterid & Balaenoptera spp. & \\
\hline Sperm whale & Physeter macrocephalus & Vulnerable \\
\hline Pygmy sperm whale & Kogia breviceps & Data Deficient \\
\hline Dwarf sperm whale & Kogia sima & Data Deficient \\
\hline Pygmy or dwarf sperm whale & Kogia spp. & \\
\hline Cuvier's beaked whale & Ziphius cavirostris & Least Concern \\
\hline Gervais' beaked whale & Mesoplodon europeaus & Data Deficient \\
\hline Rough-toothed dolphin & Steno bredanensis & Least Concern \\
\hline Common bottlenose dolphin & Tursiops truncatus & Least Concern \\
\hline Unidentified stenellid & Stenella spp. & \\
\hline Pantropical spotted dolphin & Stenella attenuata & Least Concern \\
\hline Atlantic spotted dolphin & Stenella frontalis & Data Deficient \\
\hline Spinner dolphin & Stenella longirostris & Data Deficient \\
\hline Risso’s dolphin & Grampus griseus & Least Concern \\
\hline False killer whale & Pseudorca crassidens & Data Deficient \\
\hline Killer whale & Orcinus orca & Data Deficient \\
\hline Short-finned pilot whale & Globicephala macrorhynchus & Data Deficient \\
\hline Unidentified pilot whale & Globicephala spp. & \\
\hline West Indian manatee & Trichechus manatus & Vulnerable \\
\hline \multicolumn{3}{|l|}{ POSSIBLE OCCURRENCE } \\
\hline North Atlantic right whale & Eubalaena glacialis & Endangered \\
\hline Blue whale & Balaenoptera musculus & Endangered \\
\hline Sei whale & Balaenoptera borealis & Endangered \\
\hline Common minke whale & Balaenoptera acutorostrata & Least Concern \\
\hline Blainville's beaked whale & Mesoplodon densirostris & Data Deficient \\
\hline Sowerby's beaked whale ${ }^{\mathrm{b}}$ & Mesoplodon bidens & Data Deficient \\
\hline Striped dolphin & Stenella coeruleoalba & Least Concern \\
\hline Clymene dolphin & Stenella clymene & Data Deficient \\
\hline Fraser's dolphin & Lagenodelphis hosei & Least Concern \\
\hline Melon-headed whale & Peponocephala electra & Least Concern \\
\hline Pygmy killer whale & Feresa attenuata & Data Deficient \\
\hline Hooded seal ${ }^{\mathrm{b}}$ & Cystophora cristata & Vulnerable \\
\hline
\end{tabular}

Note that several historical records of the Caribbean monk seal (Monachus tropicalis) have been documented in Cuba; however, this species is now considered extinct (NMFS 2008).

\footnotetext{
${ }^{a}$ Nomenclature still unsettled.

${ }^{\mathrm{b}}$ Indicates species that would be extralimital.
} 


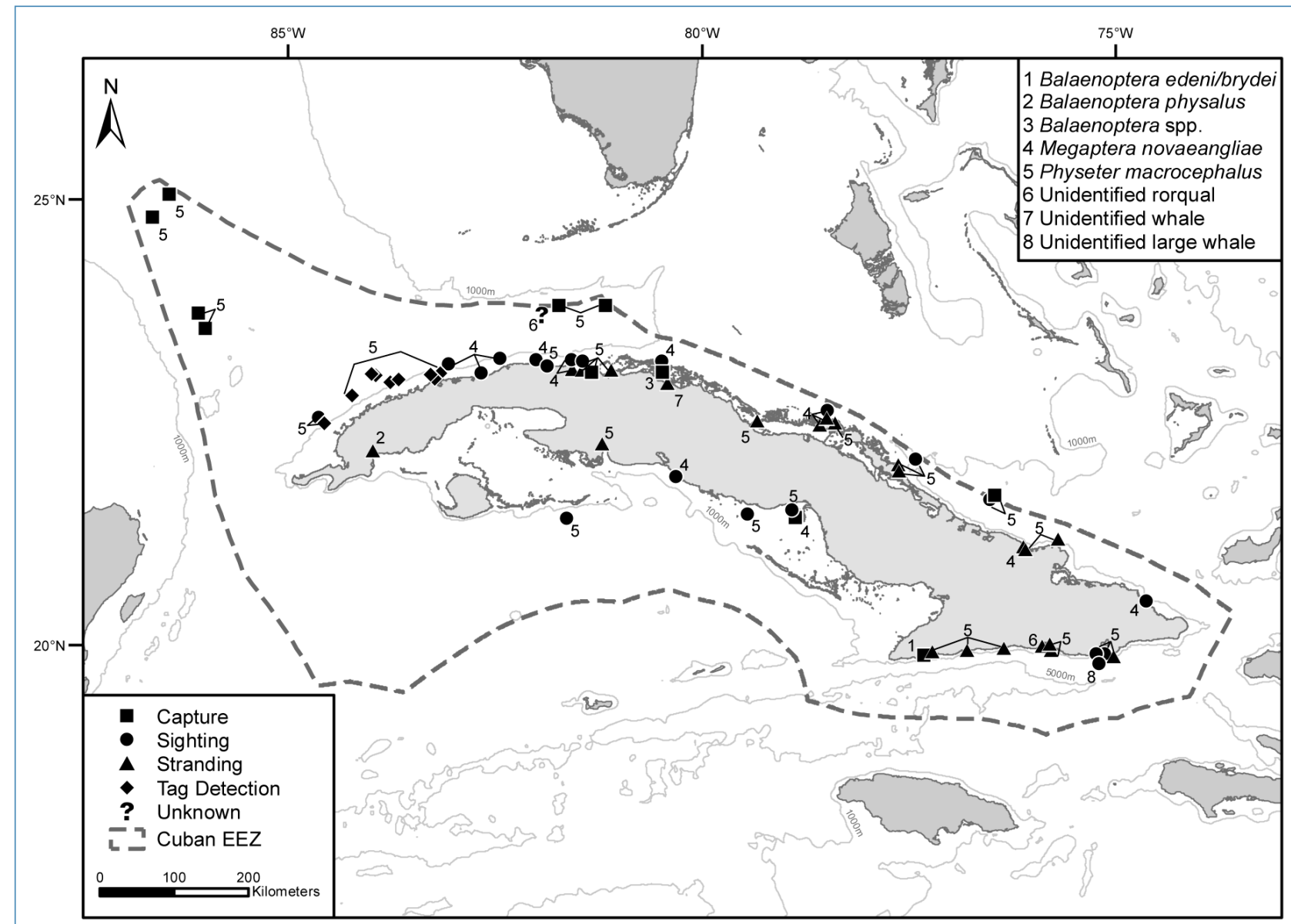

Figure 2. Records of large whales in the Cuban EEZ.

two individuals three miles from Playa Salado (Habana) in April 2006 (Blanco, 2008) ${ }^{10}$; a possible sighting in Bahía de Cádiz, (three miles from Faro, Villa Clara) in June 1997 (Blanco, 2008) ${ }^{11}$; and a possible sighting of 12 individuals recorded off the coast of southern Cienfuegos Province in June 2000. The whales were sighted by tourists diving one mile away from the Guajímico tourist villa (between Cienfuegos and Trinidad) (Figure 2). The tourists supposedly took photographs but an accurate identification could not be made ${ }^{12}$. The only records of humpback whales outside the breeding season include a confirmed stranding near Punta Tiburón, Cayo Coco and a confirmed sighting of two individuals off Cayo Coco (Blanco, $2008)^{13}$. Both records were documented in July 2002.

Seasonality is not known for the other records of humpback whales in Cuban waters. In 1839, a possible humpback whale skeleton was found at Punta de Maya, along the entrance to

\footnotetext{
${ }^{10}$ Moreno, F. and Carvajal, A., Patrón y Maquinista del Yate de Turismo Marlin, pers. comm., April 2006.

${ }^{11}$ Carrillo, E. and Echemendía J., La Cooperativa de Pesca Caibarien Villa Clara, pers. comm., July 1997.

${ }^{12}$ Whales spotted on Cuba's southern coast. Accessed 1 December 2008. http://www.radiohc.org/Distributions/Radio_Havana_English/.2000/2000_jun/Radio_Havana_Cuba-19_June_2000_22:00.

${ }^{13}$ González, O., Ministerio de Ciencia Tecnología y Medio Ambiente de

Cayo Coco, pers. comm., August 2002.
}

Bahía de Mantanzas on the northeastern coast of Cuba (de la Torre, 1907; Cuní, 1918) (Figure 2). De la Torre (1907) listed this specimen as a 'ballenato', a whale calf. Cuní (1918) stated that this was an unidentified 'ballenato' based on the notes from Dr. J. Gundlach. Scaramuzza (1943) mentioned a 1922 capture of a large whale called a 'finback' on the southern coast of Cuba near Golfo de Ana María, close to Cayo Obispo, and to the south of Júcaro (Figure 2). Although Scaramuzza referred to this animal as a 'finback', the footnote in the article specifically stated that this animal was probably a humpback whale. Varona (1973) reported that humpback whales were also historically found near Cayo Bahía de Cádiz north of Las Villas on the northern coast of Cuba. A guidebook about Cuba mentioned a humpback whale specimen that was killed by mistake in 1978 and was housed in the Museo Historia Natural in Gibara (Northern Oriente); however, no location was given for this record (McAuslan et al., 2003). We rejected the identification of this record as a humpback whale due to the lack of supporting details of how it was identified; therefore, this record is not included in the figures or appendix. In 1986, a humpback whale stranded near Jibara, Holguín off the northeastern coast of $\mathrm{Cuba}^{14}$.

${ }^{14}$ Guitart, D., Academia de Ciencias de Cuba, pers. comm., 1998. 


\section{Sei whale, Balaenoptera borealis}

Sei whales are not expected to be common in Cuban waters due to their primary distribution outside tropical waters (Jefferson et al., 2008). Five (considered extralimital) records are documented in the Gulf of Mexico; however, only four of these are reliable records (Jefferson and Schiro, 1997). There is one confirmed (likely extralimital) northeastern Caribbean stranding record from the Dominican Republic in July 1974 (Mead, 1977). Sightings designated as sei whales in the northeastern Caribbean (Erdman, 1970; Erdman et al., 1973; Mignucci-Giannoni, 1989) are not confirmed records. Neither photos nor clear diagnostic features were provided for these unconfirmed records; the species identification was based on behavioral characteristics. Likewise, there are no confirmed records of sei whales in Cuban waters. Varona (1973) reported that sei whales were historically found near Ensenada de Mora (east of Cabo Cruz) along the southwestern coast of Cuba in the 1800s. Varona (1965) reported a sei whale captured in January 1963 near Ensenada de Mora. The skull was taken to the Instituto de Biología. The English summary provided in the paper incorrectly identified the species' common name as fin whale. Mead (1977) reidentified this animal as a juvenile Bryde's whale based on descriptions of the rostrum and close examination of the baleen.

Two strandings of sei whales are listed in Blanco Domínguez (2011). However, one of these is the 1963 Bryde's whale record. The other stranding was recorded on Playa Mar Verde, Santiago de Cuba in February 1975. This is the same record listed as Balaenopteridae in Blanco's 2008 paper (Blanco, 2008). According to Blanco, specialists of the Acuario de Baconao thought that it might be a sei whale, but it was very decomposed so the specialists confirmed it to be a rorqual. The source of this stranding is Antonio Soberats Barreiro (former director of Acuario de Baconao) who believed that the specimen may have been a sei whale. However, we were not able to confirm his identification. Therefore, we list this record as "unidentified rorqual". Due to their similarity in appearance and size, many of the above records may be misidentifications of Bryde's whales which are commonly seen year-round throughout tropical and warm temperate waters (Kato, 2002).

\section{Fin whale, Balaenoptera physalus}

The range of the fin whale in the eastern North Atlantic extends from the Arctic ice edge to the Caribbean Sea and Gulf of Mexico (Gambell, 1985; Jefferson and Schiro, 1997). The fin whale may occur in coastal and oceanic waters near Cuba based on this species' known associations with continental shelf, slope, and oceanic waters throughout its range (e.g. Hain et al., 1992; Weir et al., 2001; Panigada et al., 2005). Alayo (1958) mentioned that this species had been reported from Júcaro off the southern coast of Cuba; however, the only confirmed record of this species is a stranding of an individual near Boca de Galafre, Pinar del Rio in July 1989
(Blanco, 2008; Lima, 1989) (Figure 2). A few false records of fin whales in Cuba have been recorded in the literature. As mentioned previously, a whale was captured near the Golfo de Ana María in 1922 (Scaramuzza, 1943). Scaramuzza (1943) referred to this animal as a 'finback'; however, the footnote in the article stated that this animal was probably a humpback whale. As previously noted, a juvenile fin whale was documented in Ensenada de Mora on the southeastern coast of Cuba in January 1963 (Varona, 1965). However, Mead (1977) later determined that this specimen was actually a Bryde's whale based on descriptions of the rostrum and close examination of the baleen. According to Varona (1965), the skull was taken to the Instituto de Biología.

\section{Blue whale, Balaenoptera musculus}

Blue whales in the North Atlantic range from the subtropics to Baffin Bay and the Greenland Sea (Yochem and Leatherwood, 1985). Stranding and sighting data suggest that the blue whale's original range in the Atlantic extended south to Florida, the Gulf of Mexico, the Cape Verde Islands, and the Caribbean Sea; however, the southern limit of this species' current range is unknown (Yochem and Leatherwood, 1985; Reeves et al., 2004). Researchers using the U.S. Navy's Integrated Undersea Surveillance System (IUSS) resources have been able to detect blue whales throughout the open Atlantic south to at least the same latitude as the Bahamas although several hundred kilometers to the east (Clark, 1995).

There are only two reliable records (both strandings) for blue whales in the Gulf of Mexico (Jefferson and Schiro, 1997). There are two unconfirmed reports of this species in the Gulf of Mexico, and it is possible that unidentified baleen whales from this region could be blue whales (Jefferson and Schiro, 1997). The only Caribbean record for this species is from near the Panama Canal in January 1922 (Harmer, 1923). No records of blue whales are confirmed for Cuban waters. However, based on the records from the Gulf of Mexico and this species' known range, extralimital sightings of blue whales in Cuban waters are considered possible. The species is most likely to be found in the Study Area during the winter months.

\section{Common minke whale, Balaenoptera acutorostrata}

Common minke whales (hereafter referred to as minke whales) are distributed throughout the tropics and subtropics and to the ice edges in both hemispheres (Jefferson et al., 2008). This species is known to occur in the Caribbean during the winter months, particularly between January and February (Winn and Perkins, 1976; Mitchell, 1991). However, minke whales have been reported in the Caribbean as late as May (Mignucci-Giannoni, 1998). Based on detections from U.S. Navy Sound Surveillance System (SOSUS) acoustic arrays, Clark and Gagnon (2004) suggested that minke whales move clockwise through the Caribbean during the winter. No minke whale records have been documented for Cuba; 
however, one probable sighting of three adults and a calf was recorded just north of Cuba in the Old Bahama Channel region in March 1974 (Winn and Perkins, 1976).

\section{Bryde's whale, Balaenoptera edeni/brydei}

Bryde's whales are seen year-round throughout tropical and warm temperate waters (Kato, 2002) and may be resident in the Caribbean (Mead, 1977). There is one record of a Bryde's whale captured near Ensenada de Mora along the southeast coast of Cuba in January 1963 (Varona, 1965; Mead, 1977) (Figure 2). This record was initially reported to be a juvenile sei whale (Varona, 1965) but was corrected later and determined to be a juvenile Bryde's whale based on descriptions of the rostrum and close examination of the baleen (Mead, 1977). Difficulties in distinguishing sei whales from Bryde's whales at sea may result in frequent misidentifications between these two species (Mead, 1977).

\section{Sperm whale, Physeter macrocephalus}

Sperm whales are found in polar to tropical waters in all oceans, from approximately $70^{\circ} \mathrm{N}$ to $70^{\circ} \mathrm{S}$ (Rice, 1998). They are widely distributed in the Caribbean Sea where they are commonly found near the shelf break, along the continental slope, and in passages between islands (Aguayo, 1954; Taruski and Winn, 1976; Roden and Mullin, 2000). Besides the eastern Caribbean, where extensive research has been conducted (e.g. Moore et al., 1993; Watkins et al., 1993; Gordon et al., 1998), not much is known about sperm whales in the rest of the Caribbean. Based on information from whaling logbooks from 1761 through 1920, Townsend (1935) identified the Gulf of Mexico as a main sperm whaling ground. Hunting sperm whales took place in the Gulf of Mexico and West Indies region from February to May. Based on logbook records, the distribution of sperm whales in this region appeared to be concentrated off the northern coast of Cuba, the Straits of Florida, and the southeastern Gulf of Mexico (Townsend, 1935). Townsend mapped the locations of whale ships on the days that whales were taken but did not provide coordinates or additional information for the sperm whale captures. Schmidly (1981) later estimated coordinates from the Townsend charts. No additional information, such as number of whales taken or the exact dates of the takes, were provided in Schmidly (1981) or Townsend (1935). Figure 2 only includes the whaling records of sperm whales that were captured within the Cuban EEZ. A few of Townsend's whaling records are located just outside the EEZ in the Straits of Florida.

Published records in Cuban waters date back to January 1830 when a probable sperm whale was sighted four miles offshore of the northern coast of Cuba between Matanzas and Habana (Cuní, 1918) (Figure 2). Several animals were also sighted with this individual; however, they were of varying, smaller sizes and were not confirmed to be sperm whales (Cuní, 1918). Other sperm whale sightings recorded off the northern coast of Cuba include sightings near Cayo Romano in June 1991 (Jefferson and Lynn, 1994) and off Punta de Maya, Matanzas in March 2008 (Blanco in press) ${ }^{15}$. Sperm whales were detected visually and acoustically in the Straits of Florida and just off the northwestern coast of Cuba in June 1992 (Hal Whitehead unpub. data) (Figure 2). They have been sighted in the Straits of Florida just north of the Cuban EEZ boundary and off the northeast coast according to the bridge log observations from NMFS research vessels; however, these sightings cannot be confirmed and may have been from inexperienced observers (Schmidly, 1981). One sperm whale was detected in the Cuban EEZ off the northwest coast of Cuba in 2003. This male (11m in length) was satellite tagged on 1 July 2002 off the Mississippi River Delta in the Gulf of Mexico and tracked for 607 days (Jochens et al., 2008). He moved through the Straits of Florida into the North Atlantic Ocean for around two months and spent the winter and spring in the Bay of Campeche, Mexico. On return to the Gulf of Mexico, the whale spent at least several days off the northwest coast of Cuba in November and December 2003 (Figure 2) and was detected in waters of depths ranging from 50 to $2,300 \mathrm{~m}$ (Jochens et al., 2008; Bruce Mate unpub. data).

Sightings of sperm whales off the southern coast of Cuba have been recorded off the southwestern coast in November 1995 (Blanco in press) ${ }^{16}$; off Trinidad, Sancti Spiritus in March 2002 (Blanco in press) ${ }^{16}$; near the mouth of Guantánamo Bay in 1999 (GTMO, unpub. data); and offshore of Guantánamo Bay in September 2005 (GTMO, unpub. data) (Figure 2). In February 1943, a sperm whale sighted near Cayo Obispo on the southern coast of Cuba was harpooned and brought to the harbor in Puerto de Júcaro (Scaramuzza, 1943) (Figure 2). Other captures have also been documented in Cuban waters but without exact locations (Cuní, 1918).

Strandings have been recorded along the northern coast of Cuba; specific locations include Bahía de Matanzas in 1897, between Cayo Confites and Cayo Romano in the narrowest part of the Old Bahama Channel in May 1906, and Bahía de Gibara, Holguín in 1940 (de la Torre, 1907; Cuní, 1918; Blanco Domínguez, 2011) (Figure 2). More recent strandings have been recorded near Holguín in March 1986 (Blanco in press) ${ }^{14}$; Cárdenas, Matanzas in 1996 (Blanco in press) ${ }^{14}$; Cayo Francés, Villa Clara in October 2000 (Blanco in press) ${ }^{17}$; and Cayo Coco, Ciego de Ávila in March 2006 (Blanco in press) ${ }^{18}$. Note that this last record is incorrectly listed as December 2006 in Blanco Domínguez (2011). A skeleton of a probable sperm whale was reported between Cayo Confites and Cayo Romano in 1907 and at an unknown location in Cuba in 1909 (Cuní, 1918) (Figure 2). This 1909 record is listed as being from Bahía de Cárdenas, Matanzas in Blanco Domínguez (2011), but we could not confirm this location based on the

\footnotetext{
${ }^{15}$ Blanco, M., López, N., and López, R. pers. obs., 2008.

${ }^{16}$ Cárdenas, J., Patrón del Velero Ying Yang de Puerto Sol, pers. comm., April 2002.

${ }^{17}$ Blanco, M., pers. obs., October 2000.

${ }^{18}$ Blanco, M., Pina, F., and Moré, D. pers. obs., March 2006.
} 


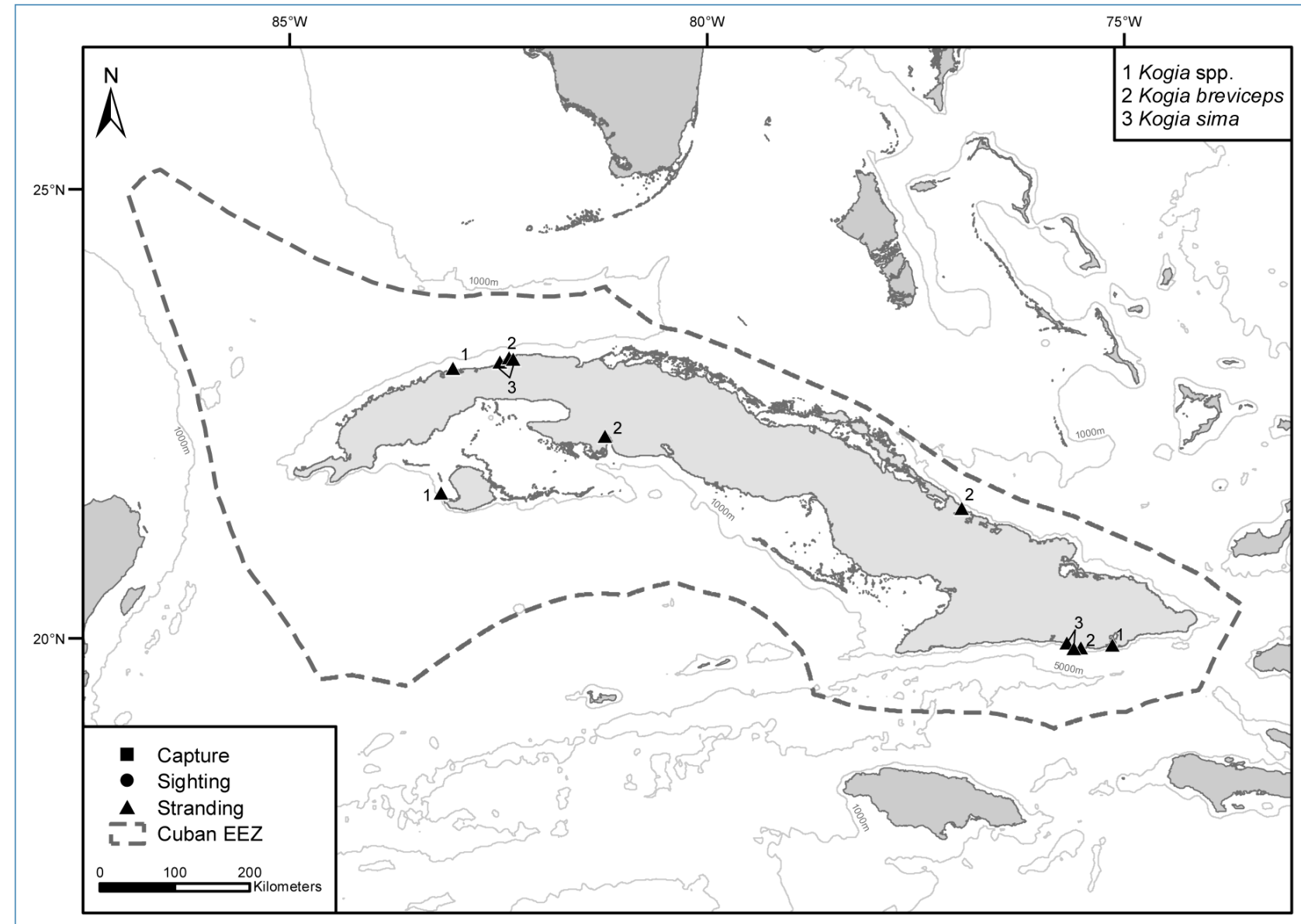

Figure 3. Records of Kogiidae in the Cuban EEZ.

information provided in Cuní (1918). Aguayo (1954) and Varona (1973) included the above-mentioned locations as well as Cayo Cupey, Matanzas in their summaries of sperm whale records in Cuba but did not give specific information on any of the records. A capture of a supposed sperm whale was anonymously reported off the coast of Matanzas in 1898 (Anonymous, 1898); however, we rejected the identification of this specimen due to the lack of information on how it was identified and any supporting documentation.

Stranding records for the southern coast of Cuba include a March 1978 stranding in Guantánamo Bay (incorrectly listed as May in Blanco Domínguez (2011)), a May 2006 stranding near Guamá (Santiago de Cuba), and a February 2008 stranding of a juvenile near Punta Tabacal (Chivirico, Santiago de Cuba) (Blanco in press) ${ }^{18,20}$ (Figure 2). All three of these skeletons are currently on display at the Museo de Historia Natural de Santiago de Cuba (Tomás Romay Museum). Additional strandings along the southern coast have been recorded near El Cuero, Santiago de Cuba in May 1989 and February 2006 (Blanco in press) ${ }^{19,21}$; Cabo Cruz,

${ }^{19}$ Lauranzon Meléndez, B., Museo de Historia Natural de Santiago de Cuba, pers. comm., 29 April 2009.

${ }^{20}$ Soberat, A., Acuario de Baconao, Santiago de Cuba, pers. comm., 1997.

${ }^{21}$ Vińa, N. and Tamayo, J.A., Centro Oriental de Ecosistemas y

Biodiversidad (BIOECO), pers. comm., February 2006.
Granma in November 1989 (Blanco in press) ${ }^{20}$; and Cienaga/ Peninsula de Zapata, Matanzas in February 1996 (Blanco in press) $)^{17}$.

\section{KOGIIDAE}

Pygmy sperm whale, Kogia breviceps, and dwarf sperm whale, Kogia sima

Kogia spp. have a worldwide distribution in deep tropical and temperate waters (Jefferson et al., 2008). Both species have been reported in the Caribbean throughout the year (Cardona-Maldonado and Mignucci-Giannoni, 1999). Dwarf and pygmy sperm whales are difficult for the inexperienced observer to distinguish from one another at sea, and sightings of either species are often categorized as Kogia spp. The difficulty in identifying pygmy and dwarf sperm whales is exacerbated by their avoidance reaction towards ships and change in behavior towards approaching survey aircraft (e.g. Würsig et al., 1998). Based on the cryptic behavior of these species and their small group sizes (much like that of beaked whales), as well as similarity in appearance, it is difficult to accurately distinguish between these species in sightings at sea. Historical records of Kogia spp. in Cuba include a skeleton reported near Ensenada de la Herradura, which is near Bahía de Manatí on Cuba's northwest coast (León and Aquayo, 1945) (Figure 3). A Kogia spp. stranding 
was recorded along the windward side of Guantánamo Bay in December 1999 (GTMO, unpub. data) (Figure 3). This stranding was originally recorded as a dwarf sperm whale; however, identification could not be confirmed to species based on the photographs of the stranded specimen. Therefore, this record was designated as a confirmed Kogia spp. stranding. Another Kogia spp. stranding was recorded near Punta Francés, Isla de la Juventud in December $2006^{22}$.

Both Kogia species have been confirmed in Cuba. Older records of the pygmy sperm whale include a skull found near Bahía de Nuevas Grandes on the northeast coast of Cuba in 1937 (Aguayo, 1954; Varona, 1980). Another record in this same area is listed as occurring in March 1954 in Blanco Domínguez (2011); however, this record is actually the same as the previous one. A stranding was also recorded near Manatí, Matanzas in June 1954 (Blanco Domínguez, 2011) (Figure 3). More recent strandings have been recorded near Playa Larga, Santiago de Cuba in 2002 and near Bahía de La Habana in May 2005 (Figure 3) ${ }^{19,23}$. The 2002 specimen is currently on display at the Tomás Romay Museum ${ }^{19}$.

A dwarf sperm whale recently stranded near the Círculo Social Obrero Los Marinos in Jaimanitas (western Habana) in August 2008 (Montolio Fernández, 2008) (Figure 3). Another dwarf sperm whale stranded near Bahía de La Habana in 1977 (Varona, 1980). Strandings of this species have also been recorded near Santiago de Cuba on the southeast coast of Cuba; one individual was found on Playa Baconao in February 2004 while the other individual was found on Playa Larga in September 2007 (Figure 3) 24,25.

\section{ZIPHIIDAE}

\section{Beaked whales, Family Ziphiidae}

There have been several records of unidentified beaked whales in the Windward Passage east of Cuba, in the Straits of Florida offshore of Habana (just outside the EEZ), and near Caibarién on the northern coast of Cuba (Aguayo, 1954; Jefferson and Lynn, 1994; Garrison and Richards, $2004)^{26}$ (Figure 4). Unidentified beaked whales have also been recorded along the northwest coast of nearby Jamaica (Rosario-Delestre et al., 1999). ${ }^{27}$

In the western North Atlantic, confirmed strandings of True's beaked whales (Mesoplodon mirus) have been recorded from Nova Scotia to Florida and also in Bermuda (MacLeod

\footnotetext{
${ }^{22}$ Anido, T., Academia de Ciencias Tecnología y Medio Ambiente de la Isla de la Juventud, pers. comm., December 2006.

${ }^{23}$ Guitart, D., Academia de Ciencias Tecnología y Medio Ambiente de Cuba, pers. comm., May 2005.

${ }^{24}$ Tamańo, J.A., Centro de Biodivercidad de Ecosistemas Costeros de la zona Oriental de Cuba, pers. comm., February 2004.

${ }^{25}$ Romero, S., Acuario de Baconao, Santiago de Cuba, pers. comm., September 2007.

${ }^{26}$ NMFS-SEFSC (National Marine Fisheries Service-Southeast Fisheries Science Center). 2004. Pelagic Observer Program data: 2000-2004. Accessed 1 December 2008. http://www.sefsc.noaa.gov/observerdata.jsp.

${ }^{27}$ Goreau, T.J., Global Coral Reef Alliance, pers. comm., 27 September 2007.
}

et al., 2006). A possible True's beaked whale stranded on the Gulf coast of Florida; however, this species is not yet confirmed for the Gulf of Mexico (Jefferson and Schiro, 1997). Balcomb (1981) and Mead (1989) reported a stranding record for True's beaked whale from the Bahamas. This record is well south of any other record of True's beaked whale and is not verified $^{28}$. Therefore, available information suggests that the True's beaked whale is not likely to occur in Cuban waters.

Cuvier's beaked whales (Ziphius cavirostris) occupy almost all temperate, subtropical, and tropical waters, as well as subpolar and even polar waters in some areas (MacLeod et al., 2006). They are documented throughout the Caribbean (e.g. Caldwell and Caldwell, 1971a; Caldwell et al., 1971b; van Bree et al., 1973; Mignucci-Giannoni, 1989; MacLeod et al., 2006; Rinaldi et al., 2006). This species was historically captured on occasion by fishermen in Cuba; Cuvier's beaked whales were often found near Caibarién, Bahía de Matanzas, Bahía de Santiago de Cuba, Carapachibey, Habana, and Boca Ciego (Varona, 1964, 1973). Aguayo (1954) reported two specimens from near Caibarién and Bahía de Matanzas on the northern coast of Cuba (Figure 4). The Bahía de Matanzas skeleton was originally housed in the Colegio de Belén in Habana but was later moved to the Museo Nacional de Historia Natural. The skull found near Caibarién was kept in the Museo Nacional de Historia Natural (Aguayo, 1954). In the 1960s, a skull without mandibles was retrieved by fishermen off the southern coast of Isla de Pinos (renamed Isla de la Juventud in 1978) (Varona, 1964). These skulls and the skeleton are the same records listed with the date February 1963 in Blanco Domínguez (2011); however, the primary sources of these records do not include specific dates (see appendix). Strandings have been recorded along the northern coast of Cuba near Habana in October 1971, November 1991, and March 2003 (Varona 1980) (Figure 4) $)^{29,30}$. A mass stranding of 14 individuals was recorded near Bahía de Nipe, Holguín in March 1986 (Figure $4)^{14}$. Strandings along the southern coast of Cuba are mostly centered around Santiago de Cuba and were recorded in August 1974, June 1979, October 1988, August 2006, and May 2007 (Blanco Domínguez, 2011) 20,31 (Figure 4). A stranding was also recorded near Bahía de Cochinos in July 1970 (Figure 4) ${ }^{14}$. A Cuvier's beaked whale skull was found on the southern coast of the Isla de Pinos near Carapachibey (Varona, 1964) (Figure 4). The only known sighting of this species in the Cuban EEZ is a confirmed sighting of four Cuvier's beaked whales recorded offshore of Habana in the Straits of Florida during an opportunistic marine mammal shipboard survey conducted by Texas A\&M University during the summer of 1991 (Jefferson and Lynn, 1994) (Figure 4).

\footnotetext{
${ }^{28}$ MacLeod, C., Beaked Whale Research Project, pers. comm., 11 March 2006.

${ }^{29}$ Blanco, M., pers. obs., November 1991.

${ }^{30}$ López, N. and Blanco, M., pers. obs. March 2003.

${ }^{31}$ Romero, Z., Acuario de Baconao, Santiago de Cuba, pers. comm., 2006 and 2007.
} 


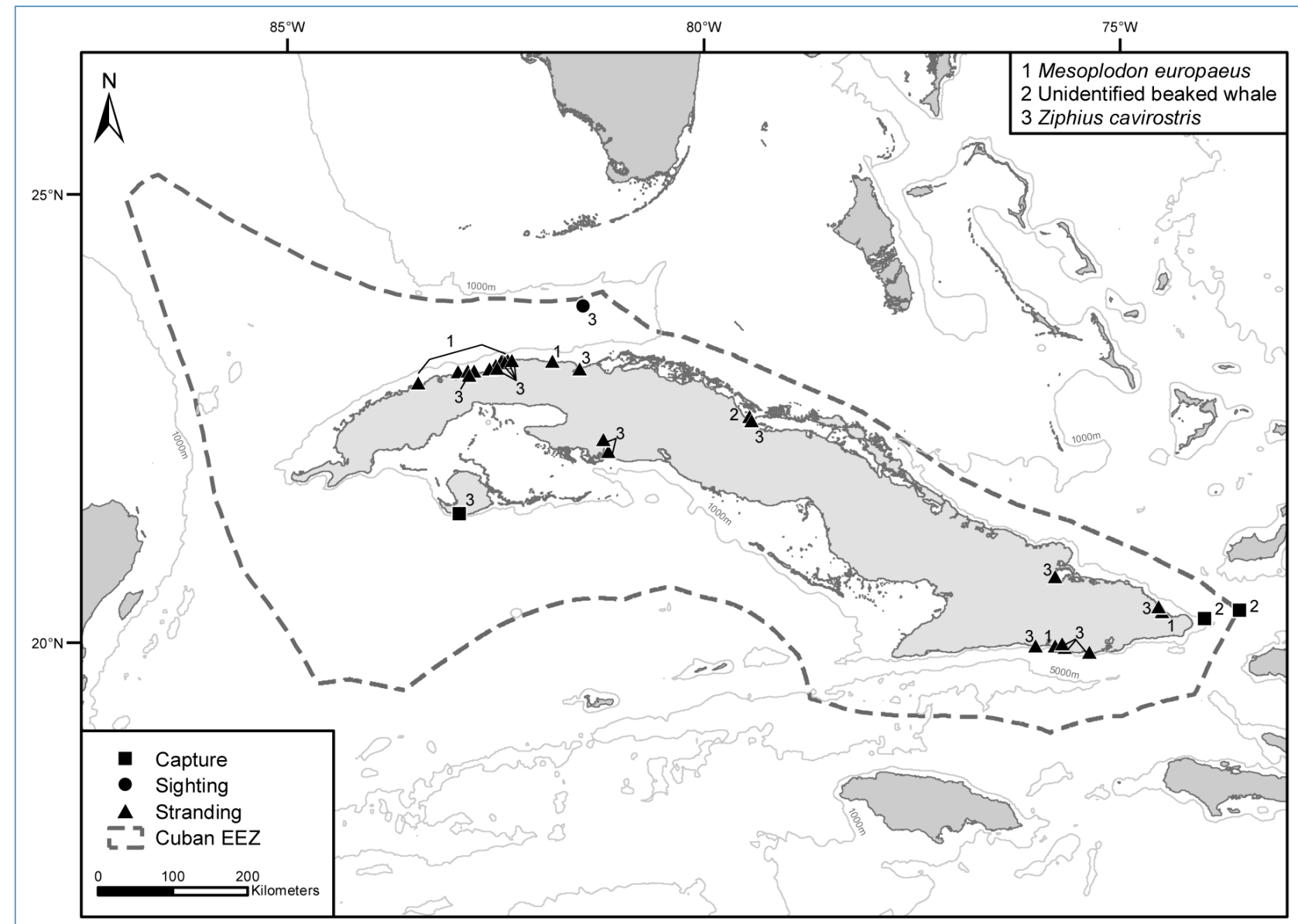

Figure 4. Records of beaked whales in the Cuban EEZ.

The Blainville's beaked whale (Mesoplodon densirostris) is thought to have a continuous distribution throughout the tropical, subtropical, and warm-temperate waters of the world's oceans, with occasional occurrences in cold-temperate areas (MacLeod et al., 2006). There are no documented records of the Blainville's beaked whale in Cuban EEZ waters; however, a stranding of a $640 \mathrm{~cm}$ male was recorded nearby in Gun Bay, Grand Cayman Island (Mead, 1989; RosarioDelestre et al., 1999). The species is regularly sighted in the Bahamas (MacLeod et al., 2004) and has been reported off Puerto Rico (Rosario-Delestre et al., 1999) and Guadeloupe (Rinaldi et al., 2006).

The Gervais' beaked whale (Mesoplodon europaeus) is endemic to the warm-temperate to tropical Atlantic (MacLeod et al., 2006) and may not be as rare in the Caribbean Sea as previously thought (Debrot, 1998). Alayo (1958) described this species as an occasional visitor to Cuba, and Varona (1973) reported that Gervais' beaked whales were often found off Cuba near Cayo Alacranes, Arroyo Bermejo, Cabañas, and Bahía Dominica. Although no sightings of this species have been documented in Cuban EEZ waters, several strandings have been recorded during November through April (Varona, 1985). Strandings have been documented in Arroyo Bermejo (east of Habana) in March 1965; Bahía Dominica in November 1971; La Puntilla in November 1982; and Barlovento, Playita de 16, and Bahía del Mariel near Habana in April 1984 (Varona, 1970, 1985; Jefferson and Schiro, 1997) (Figure 4). The oldest Cuban record of this species is a skull found in Cayo Alacranes in western Cuba (north of the Province of Pinar del Río) in November 1946 (Aguayo, 1954; Varona, 1970) (Figure 4). Rankin (1956) compared this skull to other Gervais' skulls from the Caribbean and North Atlantic and determined that it may be of an adult female. An unconfirmed stranding of this species was recorded in Pinar del Río in July 1954 (Blanco Domínguez, 2011). A complete skeleton of a female Gervais' beaked whale was found in November 1969 near Bahía de Cabañas on the northeast coast of Cuba (Varona, 1985) (Figure 4). Additional strandings have been recorded near Playa Baracoa, Guantánamo in June 1979, Playa Baracoa, Habana in August 1988, and Playa Siboney, Santiago de Cuba in October 1988 (Figure 4) 20,32. Records from nearby islands include strandings documented in Montego and Bull Bays in Jamaica and on Little Cayman in the Cayman Islands (Rankin, 1953; Caldwell, 1964; RosarioDelestre et al., 1999).

${ }^{32}$ Guitart, D. and Blanco, M., pers. obs. 
The Sowerby's beaked whale (Mesoplodon bidens) is endemic to the North Atlantic, and most records are from northern Europe (MacLeod et al., 2006). This is considered to be more of a temperate water species. A Sowerby's beaked whale stranding on the Gulf Coast of Florida has been reported but is considered to be an extralimital record (Jefferson and Schiro, 1997; MacLeod et al., 2006). Several areas of the Caribbean have been identified as key areas for beaked whales. In particular, the northern Gulf of Mexico continental shelf margins is one of these key areas and includes the Gulf of Mexico (north of the U.S./Mexico border) and extends south along the west coast of Florida to the northwest coast of Cuba (MacLeod and Mitchell, 2006). Based on the known range of this species and the record from the Gulf of Mexico, extralimital occurrences of Sowerby's beaked whales in Cuban waters are possible.

\section{DELPHINIDAE}

\section{Rough-toothed dolphin, Steno bredanensis}

Rough-toothed dolphins are found in tropical to warmtemperate waters worldwide and rarely range north of $40^{\circ} \mathrm{N}$ or south of $35^{\circ}$ S (Miyazaki and Perrin, 1994). Records from the western North Atlantic are from Virginia to Florida, the Gulf of Mexico, the West Indies, and the northeastern coast of South America (Würsig et al., 2000). It is possible that the low number of Cuban records may be a reflection of the difficulty of distinguishing the rough-toothed dolphin from other somewhat similar species such as the common bottlenose dolphin (Jefferson et al., 2008). A historical capture of a roughtoothed dolphin was documented near Habana although the date is unknown (Aguayo, 1954; Alayo, 1958) (Figure 5). Varona (1973) also mentioned the presence of rough-toothed dolphins off Habana. Strandings were recorded on Playa Chivirico, Santiago de Cuba in November $2001^{20}$ and near Santa Cruz del Norte, Habana in May $2004^{33}$.

During September 2005, two rough-toothed dolphins rehabilitated by the Marine Mammal Conservancy following a mass stranding in March 2005 were tagged with satellitelinked transmitters and released (Wells et al., 2008). The tracking data demonstrated that these individuals moved south from the Florida Keys through the Santaren Channel and Old Bahama Channel to the coastal waters off Cayo Coco and Cayo Fragoso on the northern coast of Cuba (Wells et al., 2008) (Figure 5). The rough-toothed dolphins were detected in both very shallow, nearshore waters and deep waters of the nearby submarine trench (Wells et al., 2008). Because these dolphins had stranded, had been rehabilitated over six months, and were released separate from the rest of their schoolmates, movement patterns from tracking data may not be representative of typical movement patterns of this species in this area.

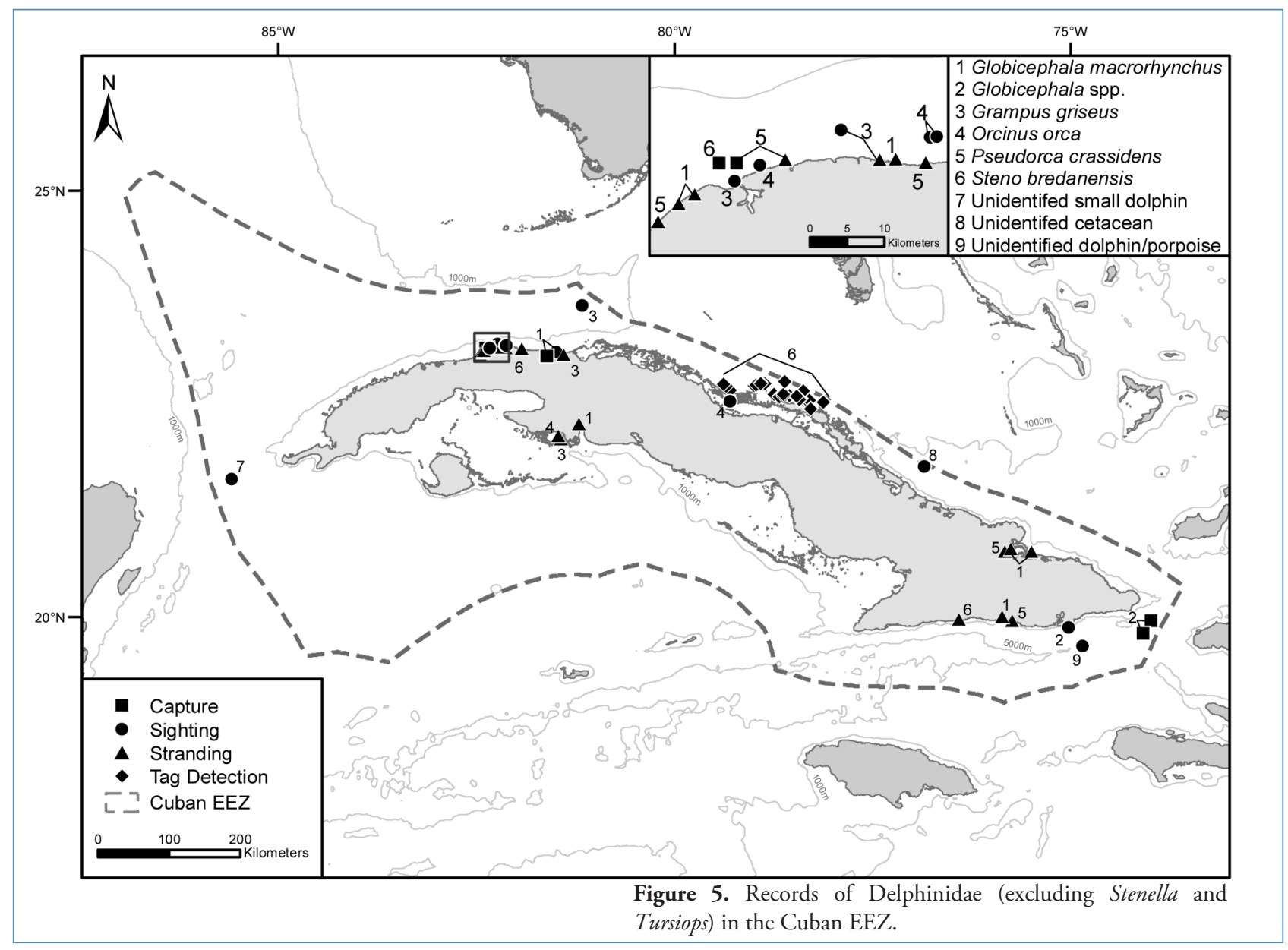




\section{Common bottlenose dolphin, Tursiops truncatus}

In the western North Atlantic, common bottlenose dolphins (hereafter referred to as bottlenose dolphins) occur as far north as Nova Scotia and are most common in coastal waters from New England to Florida, the Gulf of Mexico, the Caribbean, and southward to Venezuela and Brazil (Würsig et al., 2000). Bottlenose dolphins have been reported in all regions of the Wider Caribbean Region (Ward et al., 2001). The bottlenose dolphin is seen throughout the year in the Caribbean, primarily in waters over the shelf, and occasionally near the shelf break and farther offshore (Mignucci-Giannoni, 1989).

Bottlenose dolphins are common on the insular platform and coastal zones of Cuba year-round (López et al., 2010), and sightings have also been recorded from nearby Jamaica (e.g. Fairbairn and Haynes, 1982; Roden and Mullin, 2000). However, despite the known regular occurrence of this species around Cuba, very few studies have been conducted and few documents on the distribution of bottlenose dolphins in this region exist. Historical accounts from Aguayo (1954) and Varona (1973) claimed that bottlenose dolphins were common in Cuban waters but did not provide any specific records of occurrence. According to Pérez-Cao et al. (2009), Silva (1977) was the first publication that focused specifically on bottlenose dolphins in Cuba. This article notes the observations of the nourishing conduct of an individual in the Archipiélago de Los Canarreos in southeast Cuba. Other southeast records include a sighting of over five bottlenose dolphins off Caracoles Point in Guantánamo Bay in September 1999 (GTMO, unpub. data) (Figure 6).

Records of bottlenose dolphins off the northern coast of Cuba are better documented, particularly in the region where dolphin captures are known to occur. The Acuario Nacional de Cuba, with contributions from other Cuban institutions, has conducted numerous studies on the abundance, distribution, social structure, habitat use, genetics, and health of bottlenose dolphins in the Cuban insular platform. Researchers from the Acuario Nacional have conducted dedicated research studies on bottlenose dolphins in the Archipiélago de SabanaCamagüey region to better understand the populations from which dolphins are captured for live display. Their research in this region has focused on morphometric studies and health assessments (Blanco and Olaechea, 1996, 2000) ) $^{34}$. Acuario Nacional researchers have captured, measured, and released bottlenose dolphins off Varadero, Isabela de Sagua, and Caibarién (Blanco and Olaechea, 1996, 2000). The captures and measurements in the Varadero region to the northeast of the Península de Hicacos were conducted between 1983

${ }^{34}$ Pérez-Cao, H. (2004) Population studies on bottlenose dolphins Tursiops truncatus, in the archipelago Sabana-Camagüey, Cuba. Abstracts, Thirty-second Annual Symposium of the European Association for Aquatic Mammals. 5-8 March 2004. Valencia, Spain.

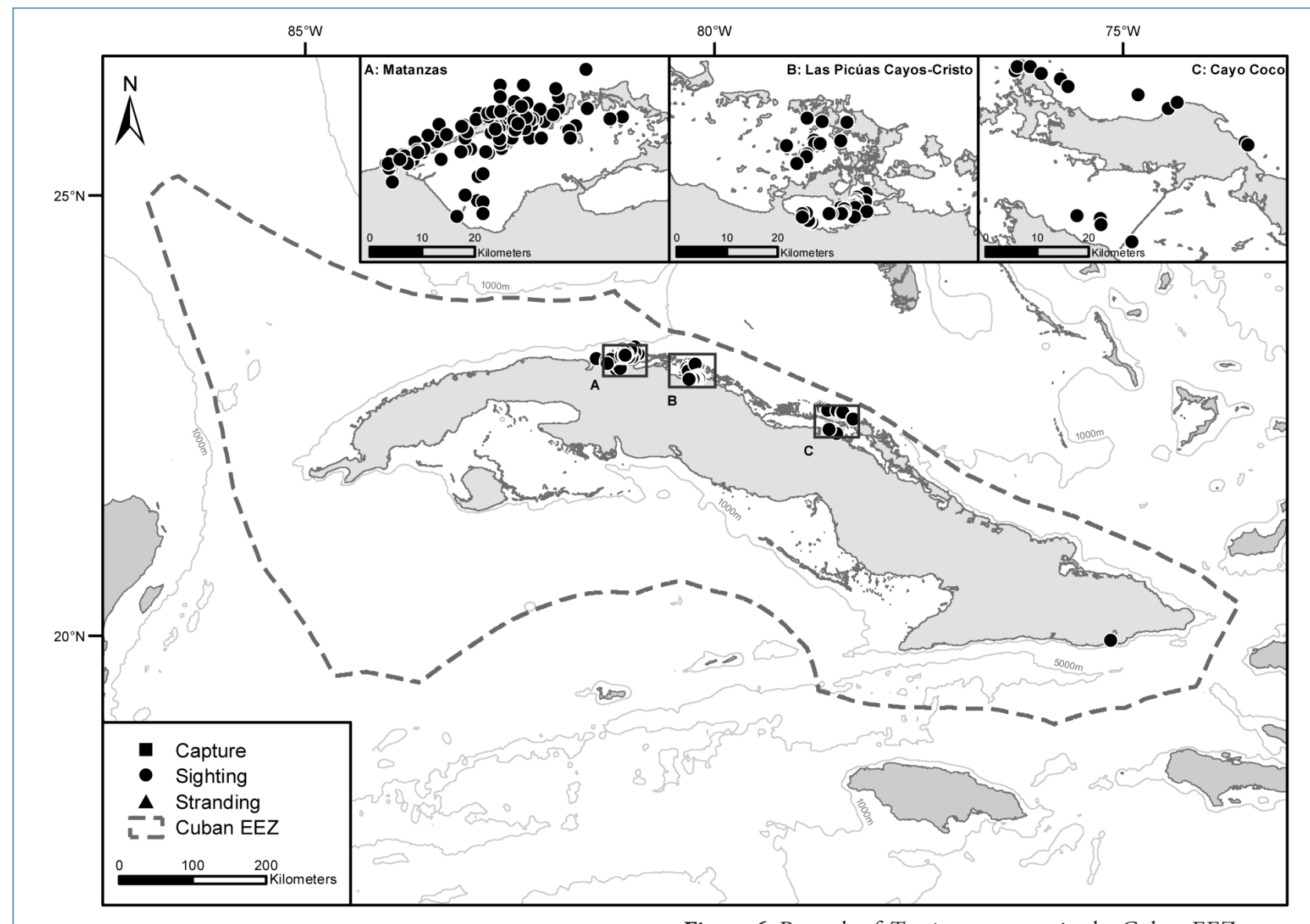

Figure 6. Records of Tursiops truncatus in the Cuban EEZ. 
and 1995 (Blanco and Olaechea, 1996). During this study period, 30 sightings of a total of 100 bottlenose dolphins were recorded (Figure 6).

Acuario Nacional researchers have also used distance sampling, mark-recapture, and photo-identification techniques to obtain information on the relative abundance, distribution, and degree of residence of bottlenose dolphins in the Archipiélago de Sabana-Camagüey region. Surveys conducted in 2000 were focused near Cayo Coco in the provinces of Ciego de Ávila and Camagüey off the Archipiélago de Camagüey (Pérez-Cao, 2004) (Figure 6). A total of 27 sightings were recorded, and 109 bottlenose dolphins were observed during these sightings. No specific geographical coordinates, dates, or group sizes were available for these 27 sightings. The sightings for these surveys included in Figure 6 were geo-referenced from the maps provided in Pérez-Cao (2004). Thirty-two of the dolphins sighted were individually identified through photo-identification; none of these was resighted during the study. The relative density of bottlenose dolphins near Cayo Coco was estimated to be 0.14 dolphins $/ \mathrm{km}^{2}$ (Pérez-Cao, 2004). The relative abundance of bottlenose dolphins was found to be higher in the Las Picúas Cayos-Cristo Marine Protected Area which is part of the Archipiélago de Sabana-Camagüey based on surveys conducted between 2005 and 2006 (Alvarez Alemán et al., 2009). A total of 42 groups of dolphins was recorded; relative abundance was 2.7 dolphins per 10NM. Sightings from these surveys were geo-referenced from figures provided by A. Alvarez Alemán (Figure 6). More detailed information on these sightings was not available.

Survey efforts between 2002 and 2009 were concentrated along the northern coast of the Matanzas Province in the Archipiélago de Sabana. Results from these surveys are discussed in Pérez-Cao (2004), Pérez-Cao et al. (2009), and López et al. (in press). Six surveys were conducted between June 2002 and August 2003 in waters off the northern coast of Matanzas in three areas: Costa Norte, Bahía de Cárdenas, and Cinco Leguas. These surveys resulted in 34 sightings of a total of 253 bottlenose dolphins; 60 individuals were photoidentified (Figure 6). Density of bottlenose dolphins in these three areas was estimated to be 1.28 dolphins $/ \mathrm{km}^{2}$ (PerezCao et al., 2009). Additional surveys from 2004 through 2009 concentrated in Costa Norte and Bahía de Cárdenas and resulted in 117 sightings (López et al., in press) (Figure 6). Relative abundance estimated from mark-recapture data was between approximately 100 and 150 dolphins for this region. Researchers identified 128 dolphins; 71 of these were observed more than once. Results from these studies support the hypothesis of a resident core population of bottlenose dolphins in this region. However, it is also possible that several wide-ranging semi-resident populations exist in this region and have an aggregate abundance of several hundreds of bottlenose dolphins (Van Waerebeek et al., 2006). To date, there are no absolute abundance estimates for bottlenose dolphin populations in Cuba. Long-term photo-identification and genetic studies are needed to determine population structure and abundance of bottlenose dolphins in Cuban waters, particularly in the Sabana-Camagüey Archipelago due to the ongoing live captures in this region.

\section{Pantropical spotted dolphin, Stenella attenuata}

The pantropical spotted dolphin is distributed in tropical and subtropical waters worldwide (Perrin and Hohn, 1994). This species has been reported throughout the Caribbean (e.g. Caldwell et al., 1971a; Taruski and Winn, 1976; Roden and Mullin, 2000; Mignucci-Giannoni et al., 2003; Boisseau et al., 2006; Gero and Whitehead, 2006; Jérémie et al., 2006). Sightings of pantropical spotted dolphins were recorded off the southwestern coast of Cuba in September 1985 and off northwestern Cuba in October 1984 (Perrin et al., 1987; Mignucci-Giannoni et al., 2003) (Figure 7). These records are displayed in the distribution map for this species in Perrin and Hohn (1994). The coordinates for these sightings are included in Perrin et al. (1987), and supplemental information is included in Mignucci-Giannoni et al. (2003). Sightings were recorded in March 1995 off southern Cuba (just outside the EEZ) during the Oregon II survey (NMFS-SEFSC 1995) and in April in the Yucatán Channel off western Cuba during surveys conducted in the late 1990s (Ortega-Ortiz, 2002) (Figure 7). Records of this species along the northern coast of Cuba include an unconfirmed stranding near Habana in July 1954 (Blanco Domínguez, 2011) and an unconfirmed sighting of 50 individuals off Cayo Francés, Villa Clara in June $2006^{35}$. Spotted dolphins, which could not be identified to species, were sighted off the western and northern coasts of Cuba between 1987 and 1992 (Whitehead unpub. data), while a Stenella spp. sighting was recorded off the western coast in 1998 (Ortega-Ortiz, 2002) (Figure 7). Sightings of pantropical spotted dolphins have also been recorded off nearby Haiti (Perrin et al., 1987; Roden and Mullin, 2000).

\section{Atlantic spotted dolphin, Stenella frontalis}

The Atlantic spotted dolphin ranges from New England to southern Brazil in the western North Atlantic (Jefferson et al., 2008). As noted by Perrin et al. (1987), the distribution of the Atlantic spotted dolphin in the Caribbean is poorly known. Sightings of this species have been recorded from Puerto Rico, the Virgin Islands, Columbia, Dominican Republic, St. Vincent, Martinique, Dominica, Guadeloupe, Venezuela, and Panama (Mignucci-Giannoni, 1989, 1998; Gero and Whitehead, 2006; Jérémie et al., 2006; Rinaldi et al., 2006). There are several records of this species in the Cuban EEZ. Varona (1980) includes strandings of Atlantic spotted dolphins in Habana in 1911 and 1967 (Figure 7). Most sightings of this species are documented along the

${ }^{35}$ Echemendía J., La Cooperativa de Pesca Caibarien Villa Clara, pers. comm., 2006. 


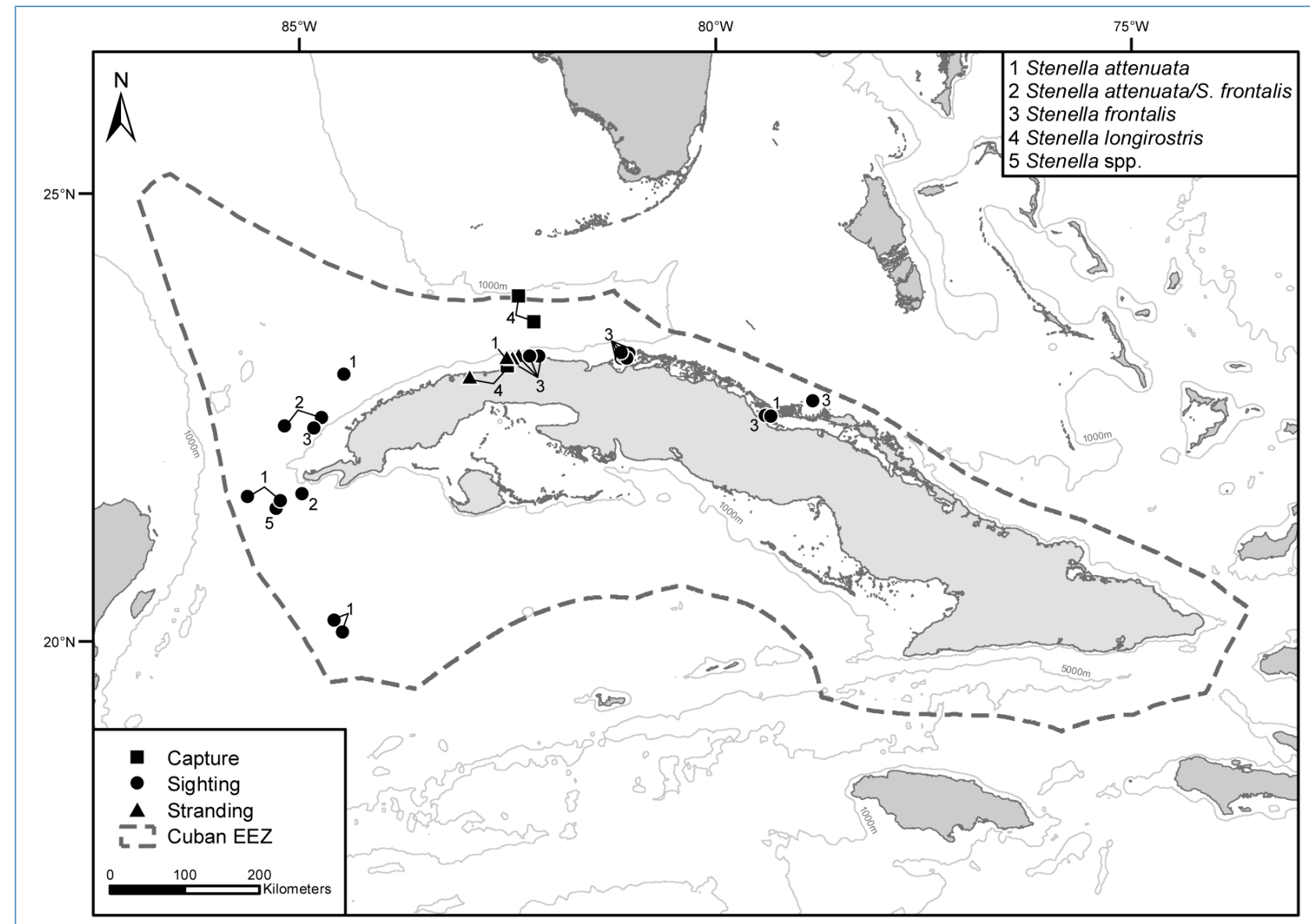

Figure 7. Records of Stenella in the Cuban EEZ.

northern coast of Cuba. Sightings of a few individuals have been recorded off Canal Varadero, Matanzas in 1991 and October 2004 (Figure 7) ${ }^{36}$. Additional sightings in Matanzas were recorded off Varadero in February, March, and August of 2008 (Figure 7) ${ }^{15,37}$. Sightings of around 100 Atlantic spotted dolphins were recorded near Habana in November 2004 and September 2005 (Figure 7) ${ }^{38}$. Several Atlantic spotted dolphins were also sighted off Caibarién, Villa Clara in April 2006 and January 2008 (Figure 7) ${ }^{39}$. The only known record of this species along southern Cuba is a sighting of two individuals off Pinar del Río in 1994 (Figure 7) ${ }^{33}$. There is also one record of this species off the southwestern coast of nearby Haiti (NMFS-SEFSC 1995; Roden and Mullin, 2000). As previously mentioned, spotted dolphins not identified to species have been recorded off the western and northern coasts of Cuba (Whitehead, unpub. data), and a Stenella spp. sighting was recorded off the western coast (Ortega-Ortiz, 2002) (Figure 7).

\footnotetext{
${ }^{36}$ Guevara, C. and Blanco, M., pers. obs.

${ }^{37}$ Rivera, J., Mundo Latino, Habana, pers. comm., 2008.

${ }^{38}$ Martínez, E., Patrón de la embarcacion Veneciana II de la Marina de

Tarara, Habana, pers. comm., 2005.

${ }^{39}$ Isla, V., Acuario Nacional de Cuba, pers. comm., 2008.
}

\section{Striped dolphin, Stenella coeruleoalba}

Striped dolphins are distributed throughout the temperate, subtropical, and tropical waters of the western North Atlantic (Leatherwood et al., 1976). Striped dolphins are not common in most truly tropical areas and are only occasionally reported in the Caribbean. There have been a few sighting and stranding records of this species in the Caribbean (van Bree, 1975; Jefferson and Lynn, 1994; Mignucci-Giannoni, 1996; Debrot et al., 1998; Roden and Mullin, 2000; Gero and Whitehead, 2006; Rinaldi et al., 2006). There are currently no records of this species in Cuban waters. However, this species has been documented from nearby Jamaica. For instance, True (1889) referred to a striped dolphin skull from Jamaica that is preserved in the Royal Victoria Hospital, Netley (museum specimen number RVH179). Wilson et al. (1987) cited this record but wrongly credited Perrin et al. (1981) as the source. Van Bree (1975) stated that a striped dolphin was caught near or stranded on Jamaica and cited True (1889) for this information. 


\section{Spinner dolphin, Stenella longirostris}

The spinner dolphin is found in tropical and subtropical waters worldwide with range limits near $40^{\circ} \mathrm{N}$ and $40^{\circ} \mathrm{S}$ (Jefferson et al., 2008). Spinner dolphins have been reported for various locations in the Caribbean, such as Bequia, the Grenadines, Tobago, St. Vincent, Puerto Rico, the Virgin Islands, Guadeloupe, Dominica, Curacao, and Martinique (Caldwell et al., 1971a; Mignucci-Giannoni, 1989; Jefferson and Lynn, 1994; Mignucci-Giannoni, 1998; Jérémie, 2005; Rinaldi et al., 2006). Only three records have been confirmed for Cuba. Perrin et al. (1981) reported one spinner dolphin captured off Jaimanitas Beach west of Habana in November 1960 (Figure 7). In addition, two bycatch records were documented in the Straits of Florida offshore of Habana in June 2003 (Figure 7) ${ }^{26}$. One unconfirmed spinner dolphin stranded near Bahía Cabaña in the southeastern region of Cuba in March $1989^{20}$.

\section{Clymene dolphin, Stenella clymene}

Clymene dolphins are distributed in tropical and subtropical waters of the Atlantic Ocean, including the Gulf of Mexico and Caribbean Sea (Jefferson et al., 2008). There are currently no known records of this species in Cuban waters. Jefferson et al. (1995) noted that the absence of records for the Clymene dolphin in Cuban waters was probably due to the lack of systematic surveys. Caldwell (1961) reported a Stenella spp. sighting off the southern coast of nearby Jamaica; this record was probably a Clymene dolphin (Jefferson and Curry, 2003). Another Stenella spp. sighting was recorded off the western coast of Cuba (Ortega-Ortiz, 2002) (Figure 7).

\section{Fraser's dolphin, Lagenodelphis hosei}

The Fraser's dolphin is a pantropical species found primarily between $30^{\circ} \mathrm{N}$ and $30^{\circ} \mathrm{S}$ (Jefferson et al., 2008). There are few records from the Atlantic Ocean, in particular, the Caribbean (Leatherwood et al., 1993; Watkins et al., 1994). Published records include a few catches off the Lesser Antillean island of St. Vincent, two strandings on Puerto Rico, sightings off Dominica, a mass stranding in the Florida Keys, sightings off Martinique, and sightings off Guadeloupe (Caldwell et al., 1976; Hersh and Odell, 1986; Watkins et al., 1994; Mignucci-Giannoni et al., 1999a; Gero and Whitehead, 2006; Jérémie et al., 2006; Rinaldi et al., 2006). There are also records of this species from Venezuela (Bolaños and Villarroel-Marin, 2003). There are no records of this species in Cuban EEZ waters.

Common (short-beaked) dolphin, Delphinus delphis, and long-beaked common dolphin, Delphinus capensis

Records of Delphinus spp. have been reported throughout the Caribbean (Roden and Mullin, 2000; Jefferson et al., 2009). According to Cuní (1918), common dolphins were often caught by fishermen in Cuban waters. Both Cuní (1918) and Aguayo (1954) mentioned common dolphins in their general reviews of marine mammals of Cuba but did not provide any specific records or documentation corroborating the presence of Delphinus in this region. Jefferson et al. (2009) rejected these records as Delphinus because of a lack of supporting details; we follow that assessment for this paper.

A recent review of the occurrence of common dolphins and long-beaked common dolphins in the entire western Atlantic Ocean revealed that many reports of these dolphins in the literature are either erroneous or not verifiable (Jefferson et al., 2009). When only the confirmed records were plotted, common dolphin records were absent throughout the Gulf of Mexico, Caribbean Sea, and most of the tropical Atlantic Ocean. The only exception for the Caribbean appears to be a population of long-beaked common dolphins over the continental shelf off Venezuela. These species are most often confused with Clymene and spinner dolphins, and such confusion appears to have resulted in erroneous assumptions about their range in the Atlantic Ocean. Therefore, common dolphins are not expected to occur in Cuban waters.

\section{Risso's dolphin, Grampus griseus}

The Risso's dolphin is distributed worldwide in tropical to warm-temperate waters, roughly between $60^{\circ} \mathrm{N}$ and $60^{\circ} \mathrm{S}$, where surface water temperature is greater than $10^{\circ} \mathrm{C}$ (Kruse et al., 1999). In the western North Atlantic, this species is found from Newfoundland to the Gulf of Mexico and throughout the Caribbean (Jefferson, 2008). There are a few records of this species in Cuban waters, one of which contains conflicting information regarding species identification. In 1971, Risso's dolphins were sighted off the coast of Habana and near the mouth of the Almendares River; some of these individuals were captured by fishermen (de la Osa and Guma, 1971) (Figure 5). The de la Osa and Guma (1971) article title incorrectly refers to pilot whales, while the body of the article discusses 'Grampus griseus'. The reported animal lengths $(6-7 \mathrm{~m})$ and weights $(5,000 \mathrm{lbs})$ are too large for Grampus griseus, and the physical description, which included gray coloration and white spots scattered over the body, is not sufficient to confirm these sightings as Grampus griseus. De la Osa and Guma (1971) stated that 'other cetacea' were sighted off the Santa María del Mar Beach east of Habana on this same day but did not specify the species. However, the article alluded to the fact that these animals were the same species as those sighted near Maceo Park and the mouth of the Almendares River (Figure 5). More than one of the animals sighted around this time was captured. One was supposed to be subjected to the process of taxidermy at the Institute of Oceanography and later exhibited at the Museo Nacional de Historia Natural.

Risso's dolphins were historically reported near Bahía de Matanzas in a general review by Varona (1973). Strandings have been recorded near Bahía de Matanzas in August 1972, 
on Playa Santa María del Mar (Habana) in October 1981, and on Cayo Cobo, Caibarién (Villa Clara) in September 1997 (Varona 1980) ${ }^{40}$ (Figure 5). This 1997 stranding involved four individual Risso's dolphins. This species has also been reported offshore of Cuba in the Straits of Florida (off Cay Sal Bank) (Caldwell and Caldwell, 1977; Fritts et al., 1983; Jefferson and Lynn, 1994) (Figure 5). An adult male Risso's dolphin was tracked (via a satellite-linked Splash time-depth recording tag) just off the northern coast of Cuba (north of the EEZ) after being released offshore of Sarasota, Florida in February 2006, following rehabilitation associated with a mass stranding (Wells et al., 2009). The sighting off Cay Sal Bank in the Straits of Florida is the only confirmed sighting of this species in the Cuban EEZ; however, sightings in deep waters off Cuba are possible year-round.

\section{Melon-headed whale, Peponocephala electra}

Melon-headed whales occur in deep tropical and subtropical waters worldwide (Perryman et al., 1994). Records of this species have been documented in the Gulf of Mexico since 1990 (Barron and Jefferson, 1993; Mullin et al., 1994). Several records have been documented for the Caribbean including captures near St. Vincent, Lesser Antilles (Caldwell et al., 1976; Mead et al., 1986); a stranding in northeast Puerto Rico (Mignucci-Giannoni et al., 1998); sightings near Dominica (Watkins et al., 1997; Gero and Whitehead, 2006); a stranding in Venezuela (Bolaños and Villarroel-Marin, 2003); and strandings and sightings off the Leeward Dutch Antilles (Debrot et al., 1998). There are no confirmed records of melonheaded whales in Cuban waters; however, based on the known range of this species and the above-mentioned records in the Caribbean, melon-headed whales may occur in deep waters off Cuba.

\section{Pygmy killer whale, Feresa attenuata}

Pygmy killer whales have a worldwide distribution in tropical and subtropical waters, generally not ranging north of $40^{\circ} \mathrm{N}$ or south of $35^{\circ} \mathrm{S}$ (Jefferson, 2008). Several strandings of this species have been documented in the Gulf of Mexico (Jefferson and Schiro, 1997). Pygmy killer whales are thought to occur year-round in the Gulf of Mexico in small numbers (Würsig et al., 2000). Only a few records are confirmed for this species in the Caribbean: a skull collected from captures in St. Vincent (Caldwell and Caldwell, 1971b), a mass stranding in the British Virgin Islands (Mignucci-Giannoni et al., 1999b), a stranding on northwest Puerto Rico (Rodríguez-López and Mignucci-Giannoni, 1999), strandings off Venezuela (Bolaños and Villarroel-Marin, 2003), a sighting off Dominica (Gero and Whitehead, 2006), and sightings off Guadeloupe (Rinaldi et al., 2006). There are no records of this species in Cuban waters; however, pygmy killer whales may occur in deep waters off the coast of Cuba.

\footnotetext{
${ }^{40}$ Sánchez, L., Acuario Nacional de Cuba, pers. comm., 1997.
}

\section{False killer whale, Pseudorca crassidens}

False killer whales are found in tropical and temperate waters, generally between $50^{\circ} \mathrm{S}$ and $50^{\circ} \mathrm{N}$ with a few records north of $50^{\circ} \mathrm{N}$ in the Pacific and the Atlantic (Baird et al., 1989; Odell and McClune, 1999). They are widely distributed in the Caribbean (Odell and McClune, 1999) and have specifically been reported off St. Vincent and the Grenadines (Caldwell et al., 1971a; Caldwell and Caldwell, 1975), Tobago (Mörzer Bruyns, 1969), St. John (Mignucci-Giannoni, 1989), St. Lucia (Ward et al., 2001), Dominica (Hoyt, 1999), Guadeloupe (Rinaldi et al., 2006), Grenada (Boisseau et al., 2006), and Venezuela (Romero et al., 2001). There are few published records of this species in Cuban waters. One unconfirmed individual was captured by fishermen near Habana in 1858 (Cuní, 1918) (Figure 5). De la Torre $(1887$; 1907) reported a possible killer whale skeleton found in Cojímar on the northeastern coast (Figure 5). According to Cuní (1918), de la Torre later identified this skeleton as a false killer whale (Aguayo, 1954; Varona, 1973; O'Sullivan and Mullin, 1997). This specimen was supposedly preserved at the Academia de Ciencias Médicas, Físicas y Naturales in Habana (Cuní, 1918). Varona (1973) attempted to confirm the identity of this specimen but could not locate it in the Academia. The only confirmed records of this species are strandings in Guanabo, Habana in July 1972; Holguín in 1973; Playa Justicí (Santiago de Cuba) in March 1973; and Playa Marianao, Habana in December 1981 (Varona, 1980; 2002) ${ }^{20}$. Historically, false killer whales were known to occur near Cojímar, Playa Baracoa, and Guanabo (Varona, 1973). A sighting of five individuals was recorded outside the EEZ off Cayo Romano in 1966 (Mörzer Bruyns, 1969). Schmidly (1981) plotted this record but listed incorrect coordinates. A group of 15 false killer whales was sighted in the Straits of Florida in March 2001 but were outside of the Cuban EEZ (Mullin et al., 2001).

\section{Killer whale, Orcinus orca}

Killer whales are found throughout all oceans and contiguous seas. In the western North Atlantic, killer whales are known from the polar pack ice southward to Florida, the Lesser Antilles, and the Gulf of Mexico where they have been sighted year-round (Leatherwood et al., 1976; Jefferson and Schiro, 1997). In the Caribbean, killer whales have been recorded off Puerto Rico and the Virgin Islands, St. Vincent, Cayman Islands, Dominican Republic, Guadeloupe, Grenada, Trinidad and Tobago, St. Lucia, and Venezuela (Erdman, 1970; Caldwell et al., 1971a; Mignucci-Giannoni, 1989; 1998; Boisseau et al., 2006; Rinaldi et al., 2006; Bolaños-Jiménez et al., 2008). Sightings of this species in the Caribbean have been documented over the continental shelf and farther offshore (e.g. Mignucci-Giannoni, 1989; Bolaños-Jiménez et al., 2008) ${ }^{41}$.

\footnotetext{
${ }^{41}$ Dunn, C.A., D.E. Claridge, and T.L. Pusser (2007) Killer whale (Orcinus orca) occurrence and predation in the Bahamas. Abstracts, 17th Biennial Conference on the Biology of Marine Mammals. 29 November - 3 December 2007. Cape Town, South Africa.
} 
Few records of killer whales have been documented in the Cuban EEZ. Three sightings of this species are documented off La Habana: three individuals were sighted off Baracoa in 1983 while the other two sightings were both off Guanabo (one individual in August 1984 and four individuals in August 1994) (Figure 5) ${ }^{32,36}$. The other known records of this species are off Caibarién in Villa Clara (Figure 5). Four killer whales were sighted in this region in $2005^{35}$ while a stranded individual was found on Cayo Cobo in April 2004 ${ }^{42}$. The following historical records are documented just north of the Cuban EEZ boundary: a March 1948 stranding on Summerland Key (Moore, 1953) and a 1921 capture off the Florida Keys (Katona et al., 1988). Killer whales have also been recorded nearby off the Cayman Islands and Haiti. Katona et al. (1988) reported a sighting of eight or nine killer whales off Grand Cayman Island in October 1986. A sighting of 10 individuals was recorded seven miles off East End, Grand Cayman Island in July 2008 (Cayman Islands Department of Environment unpub. data). Reeves and Mitchell (1988) documented killer whales off the coast of Haiti based on historical whaling records. They also provided coordinates of a killer whale sighting on 29 July 1872 that corresponds to a location about $42 \mathrm{~km}$ inland of Cuba; this sighting is based on the whaling logbook of the schooner Cohannet between 1872 and 1873 (Reeves and Mitchell, 1988). We were unable to locate the Cohannet logbook to find the correct coordinates of this record. Therefore, this record could not be confirmed and is not included in this summary of killer whale records for $\mathrm{Cuba}^{43}$.

There are some erroneous records of killer whales in Cuba. As mentioned previously, the possible killer whale skeleton found in Cojímar in 1886 was actually a false killer whale (de la Torre, 1887; Cuní, 1918). Katona et al. (1988) reported a killer whale sighting off the southern coast of Cuba east of Isla de la Juventud. The coordinates for this sighting correspond to this region of Cuba; however, the location described in the paper is Vero Beach, Florida. Since the coordinates for the location of this sighting were likely mistaken in the Katona paper, this record is not considered to be from Cuban waters in this assessment.

\section{Short-finned pilot whale, Globicephala macrorhynchus}

Short-finned pilot whales are found worldwide in warmtemperate and tropical waters, generally not north of $50^{\circ} \mathrm{N}$ or south of $40^{\circ} \mathrm{S}$ (Jefferson et al., 2008). This species has a wide distribution in the Caribbean and is commonly sighted (e.g. Caldwell and Erdman, 1963; Watkins and Moore, 1982; Mattila and Clapham, 1989; Boisseau et al., 2006; Jérémie et al., 2006). The first known account of pilot whales in Cuban EEZ waters was a sighting of three individuals near Bahía de Matanzas in September 1908 (Cuní, 1918) (Figure 5). One of

\footnotetext{
${ }^{42}$ Blanco, M., pers. obs., April 2004.

${ }^{43}$ Reeves, R., Okapi Wildlife Associates, pers. comm., 25 October 2007.
}

these animals was later captured in the Yumurí River (Figure 5) and identified as a long-finned pilot whale ( $G$. melas) according to Cuní (1918). However, Cuba is well south of the known range of long-finned pilot whales (Jefferson et al., 2008). The photos of the specimen included in Cuní (1918) were of a short-finned pilot whale; therefore, we confirmed these records for this species. Agauyo (1954) verified the identification of this specimen as a short-finned pilot whale and stated that the skeleton of this specimen was preserved at the Institute of Matanzas which does not exist today. Cuní (1918) mentioned short-finned pilot whales in his review of marine mammals of Cuba but did not refer to any specific records of this species. No other sightings or captures of this species are documented in Cuban waters. However, sightings of short-finned pilot whales have been documented in the Straits of Florida (Jefferson and Schiro, 1997). De la Osa and Guma (1971) discussed a record of pilot whales off the coast of Cuba; however, these were actually Risso's dolphins. This paper was cited incorrectly in Mitchell (1975), which refers to the capture record as being of a short-finned pilot whale. Two bycatch records were reported for pilot whales off the eastern edge of Cuba in February 2004 (NMFS-SEFSC 2004) (Figure 5). A probable sighting of pilot whales was recorded about $15 \mathrm{~km}$ south of the mouth of Guantánamo Bay in September 2005 (GTMO, unpub. data) (Figure 5). This sighting and the previous bycatch records could not be confirmed to species; therefore, they are denoted as Globicephala spp. in this assessment. Based on the species' known ranges, these records are most likely of short-finned pilot whales.

Several strandings of short-finned pilot whales have been documented throughout Cuba. Three of the confirmed strandings (all of single whales) were recorded near Habana in 1964, November 1971, and October 1981 (Varona, $1980)^{23}$. An unconfirmed stranding near Bahía de Matanzas was identified as G. macrorhynchus by G. Aguayo in July 1954 (Blanco Domínguez, 2011). In February/March 1986, a group of 14 short-finned pilot whales stranded near Cayo Saetía, Holguín while another group of two whales stranded near this same region ${ }^{23}$. In 1988, one whale stranded near Bahía Santiago de Cuba in September ${ }^{20}$, and two whales stranded near Playa Larga, Matanzas in November ${ }^{32}$.

\section{TRICHECHIDAE}

\section{West Indian manatee, Trichechus manatus}

The West Indian manatee occurs along coastal areas throughout the Gulf of Mexico and Caribbean Sea, the southeastern U.S., and from the northern and eastern waters of South America to northeastern Brazil (Lefebvre et al., 2001; Parente et al., 2004; Fertl et al., 2005) ${ }^{44}$.

\footnotetext{
${ }^{44}$ Mignucci-Giannoni, A.A. and Self-Sullivan, C. (2005) Conservation status of the Antillean manatee (Trichechus manatus manatus) in the wider Caribbean. Sirenian International Symposium: Exploring sirenian related issues. A workshop held in conjunction with the Sixteenth Biennial Conference on the Biology of Marine Mammals. 11 December 2005. San Diego, California, USA.
} 
Manatee occurrence in Cuban waters was noted as early as 1494 when Columbus witnessed large groups of manatees associated with the subterranean freshwater springs that flow into the Bahía de Cochinos (Morison, 1942). In his 1535 book, Historia General y Natural de las Indias: Part 1, Gonzalo Fernández de Oviedo described the hunting of manatees off the coast of Cuba (summarized in Cuní 1918). Cuní (1918) also reported that manatees were historically abundant in Cuba, especially in estuaries, freshwater springs, and river mouths. Particularly important rivers included the Hatiguanico River near Bahía de Cochinos and the Gonzalo, Agabama, and Manatí Rivers of south-central Cuba. The Máximo (in northeastern Cuba) and Guantánamo Rivers are also known primary river habitats for manatees in Cuba (Roca and Sedaghatkish, 1998; Self-Sullivan and MignucciGiannoni, 2005).

The Cuban population of manatees decreased dramatically in the late 1800s due to the local manatee fishery. In 1901, manatee catches were prohibited in Cuba to allow for recovery of the population (Cuní, 1918). Manatees have been legally protected in Cuba since 1936 (Decree 707, Article 39), and the Ministry of Fisheries permanently prohibited the capture of manatees in Cuban territorial waters in 1982 (Lefebvre et al., 2001). However, the Cuban manatee population is thought to be declining (Self-Sullivan and Mignucci-Giannoni, 2005). Hunting, modification of habitat, drowning and entanglement in fishing nets, and underwater explosions related to petroleum extraction are current known causes of mortality for manatees in Cuba (UNEP, 1995; Lefebvre et al., 2001) ${ }^{45}$. Efforts are underway to increase awareness of manatee conservation and to identify causes of mortality in Cuba. Cuban agencies, such as the Empresa Nacional para la Protección de la Flora y la Fauna of the Ministry of Agriculture, have worked to develop manatee conservation actions which include a country-wide manatee conservation plan and an interagency manatee conservation team ${ }^{45}$. This agency is also working to change fishing practices; establish coastal biological stations; train biologists in manatee research; and establish sanctuaries, a manatee sighting and stranding network, and environmental education and outreach opportunities ${ }^{45}$.

Sightings and strandings have been recorded throughout Cuban coastal waters, particularly on the western coast near Arroyos de Mantua and Puerto Esperanza (León and Aquayo, 1945; Estrada and Ferrer, 1987). Based on a survey of fisherman in 1984 and 1985 in western Cuba, occurrences were documented in three main regions: Bahía de Cortés (between La Coloma and Cortés), Bahía de la Broa (near Batabanó), and Bahía de Guanacabibes (Estrada and Ferrer, 1987). The locations of these sightings are estimated in Figure 8. During

\footnotetext{
${ }^{45}$ Powell, J.A., A. Alvarez Alemán, and N. Auil. (2009) Manatee research and conservation in Cuba. Proceedings of the 2009 International Sirenian Conference. 23-24 March. Atlanta, Georgia.
}

the late 1980s, another survey of fishermen was conducted throughout most of Cuba (Lefebvre et al., 2001). Based on these interviews, manatees were thought to occur along both the northern and southern coasts, and the following areas were identified as having the greatest abundances of manatees: Ensenada de Guadiana-Puerto Esperanza, Bahía de Cárdenas, Carahatas-Caibarién, Turiguanó, Nuevitas-Puerto Padre, and Gibara-Cayo Saetía on the northern coast and Siguanea and Punta del Este (Isla de la Juventud), Ensenada de la Broa, Casilda-Tunas de Zaza, Golfo de Ana María, Golfo de Guacanayabo-Ensenada de Mora, and Baitiquirí on the southern coast (Lefebvre et al., 2001).

In addition to the fishermen surveys, aerial surveys conducted along much of the Cuban coastline have provided important information on the distribution of manatees in Cuba. Between 1985 and 1987, Carlos Wotzkow flew surveys over two regions along the southern coast of Cuba (Ensenada de la Broa and the south coast of Sancti Spíritus Province). During these surveys, 59 and 39 manatee sightings were recorded, respectively (Domning, 1990). Between 1986 and 1992, additional surveys were flown over Ensenada de la Broa, the Hatiguanico River, and the Zapata Peninsula. These surveys resulted in 25 sightings in November 1986, 39 sightings in July 1987, and 20 sightings in July 1992 (Lefebvre et al., 2001). A total of 44 sightings were recorded during surveys flown between the mouths of the rivers Jatibonico del Sur and Agabama-Manatí (south of Sancti Spíritus Province) in October 1985 and January 1986 (Lefebvre et al., 2001). Data from these aerial surveys were not available for inclusion in this paper.

In eastern Cuba, manatee records have been documented throughout the Guantánamo Bay region year-round. In July 1996, boat-based, shore-based, and aerial surveys were conducted to assess the abundance of manatees in Guantánamo Bay and to develop a program to monitor the manatee population at GTMO (Roca and Sedaghatkish, 1998). The surveys recorded manatees in several areas of Guantánamo Bay, particularly in the western portion and near Guantánamo River (Roca and Sedaghatkish, 1998) (Figure 8). Specific sighting locations from these surveys included Hospital Cay, near the Casa del Mar barge, and Deer Point (Roca and Sedaghatkish, 1998) (Figure 8). Based on interviews of Guantánamo residents and other anecdotal information, manatees have been sighted in central Guantánamo Bay and near Phillip's Pier and Radio Point (Roca and Sedaghatkish, 1998) (Figure 8). Sightings have also been reported in Guantánamo River and along the coast near Hidden Beach and Cuzco Beach (Howe, 1999) (Figure 8). Manatees likely utilize freshwater sources in the Guantánamo Bay region, such as local marinas (i.e. from freshwater hoses), flow from the Guantánamo River, and the effluent from the main waste water treatment facility on Lizard Island. Manatees in other locales are known to utilize similar freshwater sources for drinking (Lefebvre et al., 2001). For example, manatee 


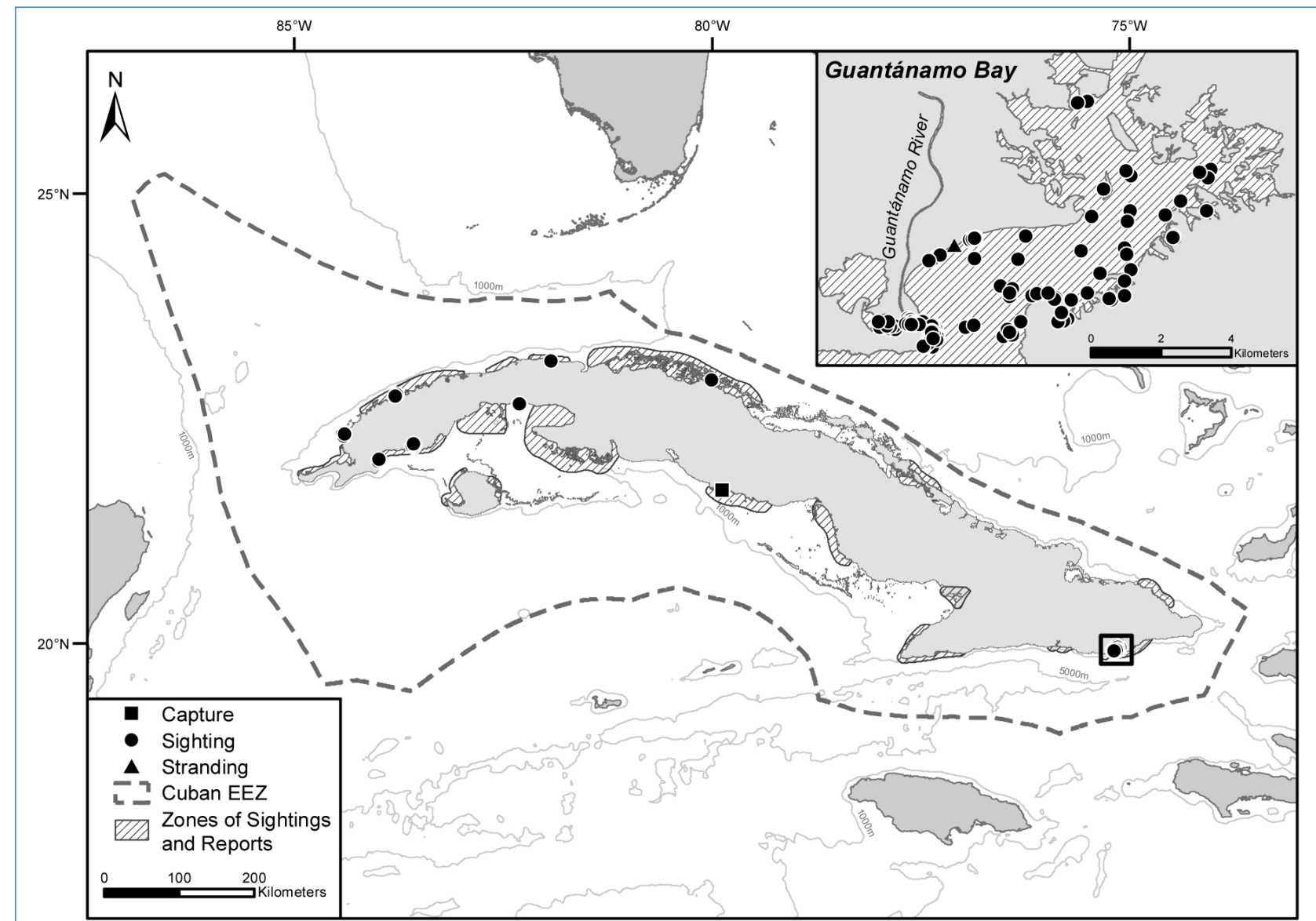

Figure 8. Records and zones of sightings and reports (Álvarez Alemán, 2011) of Trichechus manatus in the Cuban EEZ.

concentration around waste water outfalls has been noted near the Roosevelt Roads Naval Station, Puerto Rico (Powell et al., 1981). Smaller waste water outfalls in Guantánamo Bay are located near Granadillo, Bargo, Radio, Caravella, and Paola Points; Admin Hill; Corinaso Cove; and the area just northeast of Villamar. Manatees may concentrate around any of these areas and have been sighted at Fisherman's Point near the warm water effluent of the desalinization plant (Roca and Sedaghatkish, 1998). Noted areas of high habitat use in the Guantánamo Bay region include the windward channels off the main bay, the designated Manatee Conservation Zone which includes the leeward shoreline out to $137 \mathrm{~m}$ (150yd) offshore, the St. Nicholas Channel, Mahomilla Bay, and the Guantánamo River (Schoenfeld, 2005). There are No Wake Zones designated throughout these high-use areas (Schoenfeld, 2005).

In 2002, the Empresa Nacional para la Protección de la Flora y la Fauna of the Ministry of Agriculture and the Centro de Investigaciones Marinas (CIM) of the Universidad de La Habana developed a research program to determine the status and distribution of manatees in Cuba (Santos Marińo, 2007). Based on interviews with fishermen, habitat studies, and coastal site analyses, manatees are thought to occur along practically the entire coast of Cuba (Santos Mariño, 2007). General zones of sightings and reports are documented in coastal areas throughout the country (Álvarez Alemán, 2011) (Figure 8). With assistance from the Wildlife Trust, the CIM has conducted aerial surveys and radio-tagging studies of manatees in Cuban waters; however, none of these data have been published or were available for inclusion in this assessment ${ }^{46}$. Adequate data do not exist for reliable estimates of the current population of manatees in Cuban waters ${ }^{47}$, although it has been speculated to be less than 100 individuals (Self-Sullivan and Mignucci-Giannoni, 2005).

Manatee distribution in Cuba is likely influenced by the availability of freshwater and seagrass habitat (Estrada and Ferrer, 1987). Both the northern and southern coasts of Cuba contain extensive coastal manatee habitat ${ }^{45}$. Expansive riverine and estuarine areas along the southern coast (e.g. Zapata Peninsula and Golfo de Guacanayabo) provide additional habitat for this species. Manatees are most likely to occur in shallow waters around Cuba since they are associated with freshwater areas and sheltered lagoons dominated by seagrasses ${ }^{45}$. Seagrasses such as Thalassia testudinum, Halodule wrightii, and Syringodium filiform are abundant in Cuba and constitute the main food source of manatees in this region

\footnotetext{
${ }^{46}$ Álvarez Alemán, A., Centro de Investigaciones Marinas, pers. comm., 25 April 2008.

${ }^{47}$ Powell, J.A., Sea to Shore Alliance, pers. comm., 30 January 2010.
} 
(Álvarez Alemán, 2011). Individuals may occasionally be sighted farther offshore based on this species' ability to move over long distances and deep waters (Self-Sullivan and Mignucci-Giannoni, 2005). For instance, a Florida manatee was photo-documented off the northern coast of Cuba near the Camilo Cienfuegos power plant in Santa Cruz del Norte in January, February, and April 2007 (Figure 8) (AlvarezAlemán et al., 2010). The cow, which was accompanied by her calf, was photographed and matched [using the Manatee Individual Photo-identification System (MIPS)] to a known Florida manatee (CR131) that was first photographed in Crystal River, Florida in December 1979 (Alvarez-Alemán et al., 2010). This manatee was previously documented in Florida in the Crystal River in January 2005 and with a calf in the Wakulla River in July 2006. This is assumed to be the same calf that was sighted with CR131 in Cuba (AlvarezAlemán et al., 2010).

\section{PINNIPEDIA}

The only extant pinniped species that could potentially occur in Cuba is the hooded seal (Cystophora cristata) which occasionally wanders into the Caribbean (Mignucci-Giannoni and Odell, 2001; Mignucci-Giannoni and Haddow, 2002). California sea lions (Zalophus californianus) are occasionally sighted in the Caribbean; however, these individuals are feral escapees from zoos and aquaria (Mignucci-Giannoni and Odell, 2001). For example, a male California sea lion escaped from the Acuario Nacional in Habana, Cuba in March 1993 and was later recovered (Mignucci-Giannoni and Odell, 2001). The Caribbean monk seal (Monachus tropicalis) is now considered extinct. The hooded seal and historical records of the Caribbean monk seal are discussed below.

\section{Caribbean monk seal, Monachus tropicalis}

The Caribbean monk seal was present in the Caribbean until the 1950s (Kenyon, 1977). The historical range of this species likely extended from the islands west and north of Yucatán to Jamaica and included the Bay of Honduras, Cuba, the Florida Keys, and the Bahamas (Allen, 1887). The range may have also extended to the Lesser Antilles based on the historical sightings and archeological and paleontological records summarized in Timm et al. (1997).

Several historical records of this species have been documented in Cuba and just to the north near Cay Sal Bank, Bahamas (Allen, 1880; Elliott, 1884; Allen, 1887; Díaz Del Castillo, 1912; Campbell, 1978). A capture of a Caribbean monk seal was recorded near Cay Sal Bank sometime between 1868 and 1869 (Allen, 1880). In the past, it is possible that large numbers of Caribbean monk seals were distributed on some islands between Isla de Pinos, Cuba and Yucatán (Allen, 1887). Captures were recorded on Isla de Pinos during the winter between 1877 and 1878 (Allen, 1880) and near Habana in 1883 (Elliott, 1884; Allen, 1887) (Figure 9). According to Allen (1887), the seal was captured on the

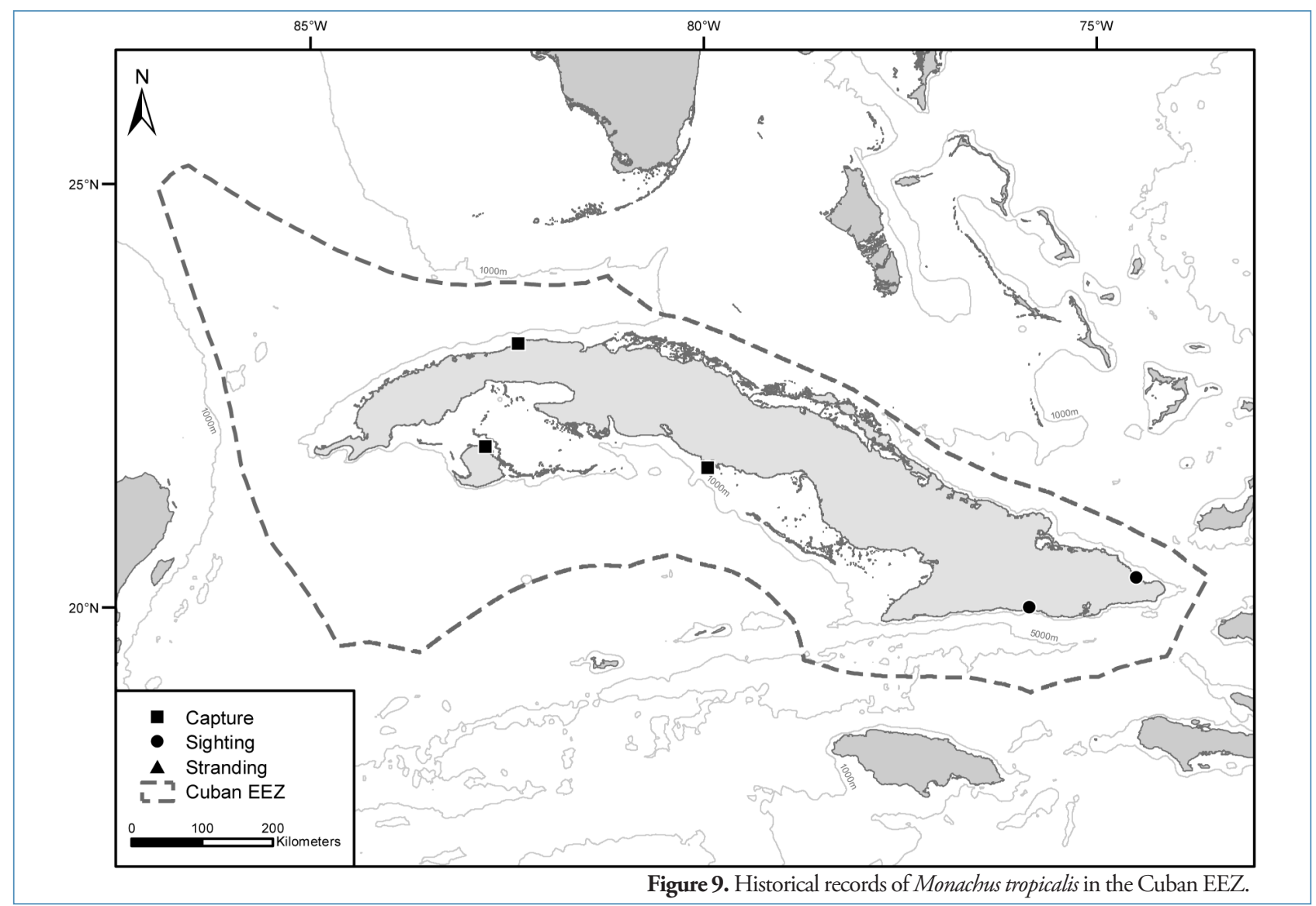


coast of Cuba, and Professor Felipe Poey had it mounted and presented it to the U.S. National Museum in October 1883. This record was mentioned in Cuní (1918) as the first specimen that was suitable for studies. Another capture off northern Cuba was mentioned in Moore (1953) and plotted in Schmidly (1981). This seal was captured by fishermen about five miles off Key West, Florida in February 1906 (Townsend, 1906). Moore (1953) included coordinates (latitude 2333' and longitude $81^{\circ} 48^{\prime}$ ) in the description of this capture, and Schmidly (1981) used these coordinates to plot the capture. However, these coordinates do not correspond to the location description given in Townsend (1906), the original source. Therefore, this record is not considered to be from Cuban waters. Other historical records of this species in Cuba include a capture near Arrecifés Viboras on the southern coast (ca. 1520) (Díaz Del Castillo, 1912) and sightings near Baracoa on the northeastern coast and Santiago on the southeastern coast in the 1930s (Campbell, 1978) (Figure 9). Lobos Cay, Great Bahama Bank off northern Cuba is one of the islets in the Caribbean with a name suggestive of seal occurrence (Timm et al., 1997). The Caribbean monk seal was officially designated as extinct on the IUCN Red List in $1996^{48}$ and was delisted under the ESA in 2008 (NMFS 2008). Therefore, future sightings of pinnipeds in Cuba are not likely to be Caribbean monk seals.

\section{Hooded seal, Cystophora cristata}

Hooded seals are found in the Atlantic region of the Arctic Ocean and in high latitudes of the North Atlantic. Hooded seals, particularly young individuals, are known to wander to locations far from their normal breeding and foraging ranges (e.g. Mignucci-Giannoni and Odell, 2001; MignucciGiannoni and Haddow, 2002). Strandings in Jamaica and the U.S. Virgin Islands represent the southernmost records for this species in the North Atlantic (Mignucci-Giannoni and Odell, 2001). No records of hooded seals have been confirmed for Cuba although Mignucci-Giannoni and Odell (2001) mentioned a sighting of an unidentified pinniped off the southern coast of Cuba in 1987.

\section{Discussion}

Seventeen cetacean species (three baleen whales and 14 toothed whales), one sirenian species, four cetacean genera (Balaenoptera spp., Kogia spp., Globicephala spp., and Stenella spp.), and one extinct pinniped species have a confirmed occurrence for Cuban EEZ waters. The bottlenose dolphin and West Indian manatee are most the common species with a total of 185 and 261 records, respectively. An additional 11 species of cetaceans and one extant pinniped species (hooded seal) have not been confirmed in Cuban waters but could potentially occur in the Study Area based on known

\footnotetext{
${ }^{48}$ Seal Specialist Group. (1996) Monachus tropicalis. In: IUCN 2007. 2007 IUCN Red List of Threatened Species. <www.iucnredlist.org>. Downloaded on 19 October 2007.
}

distributions in the Caribbean Sea. Of these, the Blainville's beaked whale has not been documented in the Study Area, but records of this species are confirmed in the nearby Cayman Islands. In addition, the minke whale is only documented near Cuba in the Old Bahama Channel just north of the EEZ boundary. The common dolphin and True's beaked whale are not documented in the Study Area and are not expected to occur in this region.

Stranding data were considered carefully when determining the distribution of marine mammals in Cuban waters. Strandings are not necessarily indicative of actual distributions since they often involve sick or injured animals which possibly move beyond their normal range. The fin whale, Gervais' beaked whale, pygmy sperm whale, and dwarf sperm whale are confirmed for the Study Area only from strandings. Therefore, it cannot be assumed that these species naturally occur in the Study Area although such occurrences would not be unexpected.

Confirmed marine mammal sightings appear to be concentrated in nearshore waters of Cuba (Figures 2 through 9). These nearshore sightings are dominated by the bottlenose dolphin and West Indian manatee which are the only marine mammal species sighted regularly and considered common, and possibly resident, in Cuban waters. However, the reported distribution of these species may be more likely a function of effort than of actual concentrations, particularly in the GTMO region where U.S. Navy personnel document marine mammal sightings on a regular basis. Bottlenose dolphin sightings are relatively well-documented on the northern coast of Cuba due to the live-capture fishery and the research efforts of the Acuario Nacional researchers in this region (Pérez-Cao, 2004; Perez-Cao et al., 2009; López et al., in press). However, bottlenose dolphin and manatee occurrences in most other areas in the Cuban EEZ are not well-documented and/or data from systematic or opportunistic surveys are not available. For example, manatee surveys and tagging studies have been conducted along the northern coast, but the resulting data were not available for inclusion in this assessment.

Beyond year-round occurrences of bottlenose dolphins and manatees in some locations, little is known about the seasonality of marine mammals in Cuban waters. Most species could occur in the Study Area during any time of the year. However, most baleen whales, such as the humpback whale, migrate between summer feeding grounds in higher latitudes and winter breeding grounds in the Caribbean (Mattila et al., 1989) so they are not as likely to occur in the Study Area during the summer months. Other marine mammals, such as the hooded seal, only occasionally travel into the Caribbean which is far beyond their normal distributional range.

To better understand the occurrence of marine mammals in Cuban waters, systematic aerial and shipboard/boat marine mammal surveys and passive acoustic monitoring are needed throughout the Cuban EEZ. Long-term photo-identification studies would be beneficial for assessing the status, abundance, 
and distribution of two common species, the West Indian manatee and bottlenose dolphin, particularly in the SabanaCamagüey Archipelago where bottlenose dolphins are captured for captive display. Photo-identification studies could help identify movement patterns of marine mammal species throughout Cuban waters and between Cuba and nearby islands of the Caribbean Sea. Genetic sampling and tagging studies are recommended for assessing movement patterns and identifying subpopulations.

Stronger collaboration among international colleagues is also a critical need, particularly for encouraging scientists to publish new findings and participate in scientific symposia and workshops. Also, a centralized database for Cuban marine mammals and support for stranding networks would be beneficial. A better understanding of marine mammal occurrence in Cuban waters is needed to support conservation and management efforts, particularly since individuals cross international boundaries and are subjected to differing levels of legislative protection.

\section{Acknowledgements}

We would like to thank the following people for their help in obtaining literature and/or collecting and verifying records: A. Álvarez Alemán, N. López, R. López, K. Van Waerebeek, R.R. Reeves, J. Mead, B. Mate, W.F. Perrin, C. MacLeod, H. Whitehead, J. Lund, J.A. Powell, T. Pitchford, K. Mullin, C. Beck, C. Taylor, A. Mignucci-Giannoni, T.J. Goreau, B. Howe, J. Wiley, S. Kromann, S. van der Woude, J. Blumenthal, M. Byrne, J. Montalvo, P. Schoenfeld, A. Yánez, F. Moreno, A. Carvajal, E. Carrillo, J. Echemendía, O. González, D. Guitart, J. Cárdenas, F. Pina, D. Moré, A. Soberat, N. Viña, J.A. Tamayo, T. Anido, S. Romero, Z. Romero, C. Guevara, J. Rivera, E. Martínez, V. Isla, L. Sánchez, R. Díaz Fernández, and B. Lauranzon Meléndez. Thanks to K. Deslarzes, J. Bolaños-Jimenez, D. Edwards, D. Antochiw Alonzo, and D. Palacios for help with literature translations, to A. Shapiro and K. Ripley for translating the draft abstract from English to Spanish, and to K. Knight for providing GIS support. A special thanks to following people for providing permission for use of their data: B. Mate (sperm whale tagging data); H. Whitehead (cetacean sighting data); P. Schoenfeld, J. Montalvo, M. Byrne, B. Howe (GTMO data); B. Lauranzon Meléndez (Tomás Romay Museum data); N. López (Acuario Nacional de Cuba bottlenose dolphin data); R. Kenney (CETAP data); J. Mead (USNM data); L. Beerkircher (NMFS-SEFSC POP data); and R. Wells (rough-toothed dolphin tagging data). Thanks to S. Rider, J.A. Powell, and two anonymous reviewers for providing comments on the draft manuscript and to J. Laliberté for reviewing the figures.

\section{References}

Aguayo, C.G. (1954) Notas sobre cetaceos de aguas Cubanas. Circulares del Museo y Biblioteca de Zoología de la Habana 13:1125-1126.

Alayo, D. (1958) Lista de los mamiferos de Cuba (vicientes y extinguidos). Universidad de Oriente, Museo Charles T. Ramsden, Santiago de Cuba.

Allen, J.A. (1880) History of North American pinnipeds: A monograph of the walruses, sea-lions, sea-bears and seals of North America. U.S. Geological and Geographical Survey of the Territories, Miscellaneous Publications 12:1-785.

Allen, J.A. (1887) The West Indian seal (Monachus tropicalis Gray). Bulletin of the American Museum of Natural History 2:1-34.

Álvarez Alemán, A. (2011) Capítulo 4.1 Mamíferos Acuáticos, El manatí. Pages 178-185 in Borroto-Páez, R. and Mancina, C.A. (Eds) Mamíferos en Cuba. Impreso por UPC Print, Vasa, Finlandia.

Alvarez-Alemán, A., Beck, C.A. and Powell, J.A. (2010) First report of a Florida manatee (Trichechus manatus latirostris) in Cuba. Aquatic Mammals 36(2):148-153.

http://dx.doi.org/10.1578/AM.36.2.2010.148

Alvarez Alemán, A., Berovides Alvarez, V., and Collazo López, J.L. (2009) Abundancia y distribución de la tonina (Tursiops truncatus, Montagu, 1821) en el área marina protegida "Las Picúas Cayo Cristo", Villa Clara, Cuba. Revista de Investigaciones Marinas 30(2):117-122.

Anonymous. (1898) A cachalote taken off Cuba: Species of whale weighing 4,000 pounds caught near Matanzas. Press Release. New York: New York Times - 5 February.

Anonymous. (2006) Wayward whales in the Gulf of Mexico. Right Whale News 13(2):8-9.

Baird, R.W., Langelier, K.M. and Stacey, P.J. (1989) First records of false killer whales, Pseudorca crassidens, in Canada. Canadian Field-Naturalist 103:368-371.

Balcomb III, K.C. (1981) Ziphiid whales from the Bahamas. Bahamas Naturalist 5(2):19-22.

Barron, G.L. and Jefferson, T.A. (1993) First records of the melon-headed whale (Peponocephala electra) from the Gulf of Mexico. Southwestern Naturalist 38(1):82-85.

Blanco, M. (2008) Varamientos y avistamientos de ballenas edentadas (Cetacea: Mysticeti) en costas y aguas Cubanas. Revista de Investigaciones Marinas 29(1):81-85.

Blanco, M. (in press) Varamientos y avistamientos de Physeter macrocephalus (Mammalia: Physeteridae) en las costas y aguas de la plataforma cubana. Revista Cubana de Ciencias Biológicas.

Blanco, M. and Olaechea, A. (2000) Morfometría del delfín nariz de botella Tursiops truncatus, en la costa norte de la zona central de Cuba. MarCuba 2000, Congreso de Ciencias del Mar, 5. 4-8 December 2000. La Habana, Cuba. 
Blanco, M. and Olaechea, A. (1996) Morfometría del delfín nariz de botella (Tursiops truncatus), en la zona de Varadero, Cuba. Memorias de la Jornada Científica 35 Aniversario. 21-22 December 1996, Acuario Nacional de Cuba, La Habana, Cuba.

Blanco Domínguez, M. (2011) Ballenas y delfines. Pages 186201 in Borroto-Páez, R. and Mancina, C.A. (Eds) Mamiferos en Cuba. Impreso por UPC Print, Vasa, Finlandia.

Boisseau, O., Leaper, R. and Moscrop, A. (2006) Observations of small cetaceans in the Eastern Caribbean. Paper SC/58/ SM24 presented to the IWC Scientific Committee, St. Kitts \& Nevis. [Available from IWC Secretariat, Cambridge, UK].

Bolaños-Jiménez, J., Fertl, D. and Iñíguez, M. (2008) Killer whale (Orcinus orca) occurrence in Venezuelan waters, 2001-2008. Paper IWC/60/SC/SM8 presented to the IWC, Santiago de Chile, June 2008. [Available from IWC Secretariat, Cambridge, UK].

Bolaños, J. and Villarroel-Marin, A. (2003) Three new records of cetacean species for Venezuelan waters. Caribbean Journal of Science 39(2):230-232.

Caldwell, D.K. (1961) Observations on an unidentified dolphin of the family Delphinidae in Jamaican waters. Caribbean Journal of Science 1(4):133-134.

Caldwell, D.K. (1964) A new record for the beaked whale, Mesoplodon europaeus, from Jamaica. Caribbean Journal of Science 4(4):547.

Caldwell, D.K. and Erdman, D.S. (1963) The pilot whale in the West Indies. Journal of Mammalogy 44(1):113-115.

Caldwell, D.K. and Caldwell, M.C. (1971a) Beaked whales, Ziphius cavirostris, in the Bahamas. Quarterly Journal of the Florida Academy of Sciences 34(2):157-160.

Caldwell, D.K. and Caldwell, M.C. (1971b) The pygmy killer whale, Feresa attenuata, in the western Atlantic, with a summary of world records. Journal of Mammalogy 52(1):206209.

Caldwell, D.K. and Caldwell, M.C. (1975) Dolphin and small whale fisheries of the Caribbean and West Indies: Occurrence, history, and catch statistics - with special reference to the Lesser Antillean Island of St. Vincent. Journal of the Fisheries Research Board of Canada 32(7):1105-1110. http://dx.doi.org/10.1139/f75-132

Caldwell, D.K. and Caldwell, M.C. (1977) The distribution, migrations, and relative abundance of Risso's dolphins, Grampus griseus, in the western North Atlantic. Prepared for Naval Ocean Systems, San Diego, California by Biological Systems, Inc., St. Augustine, Florida.

Caldwell, D.K., Caldwell, M.C. and Walker, R.V. (1976) First records for Fraser's dolphin (Lagenodephis hosei) in the Atlantic and the melon-headed whale (Peponocephala electra) in the western Atlantic. Cetology 25:1-4.

Caldwell, D.K., Rathjen, W.F. and Caldwell, M.C. (1971a) Cuvier's beaked whale, Ziphius cavirostris, from Barbados. Bulletin of the Southern California Academy of Sciences 70(1):52-53.
Caldwell, D.K., Caldwell, M.C., Rathjen, W.F. and Sullivan, J.R. (1971b) Cetaceans from the Lesser Antillean island of St. Vincent. Fishery Bulletin 69(2):303-312.

Campbell, D.G. (1978) The Ephemeral Islands: A Natural History of the Bahamas. Macmillan, London, England.

Cardona-Maldonado, M.A. and Mignucci-Giannoni, A.A. (1999) Pygmy and dwarf sperm whales in Puerto Rico and the Virgin Islands, with a review of Kogia in the Caribbean. Caribbean Journal of Science 35(1-2):29-37.

CETAP (Cetacean and Turtle Assessment Program). (1982) Characterization of marine mammals and turtles in the Midand North Atlantic areas of the U.S. Outer Continental ShelfFinal report of the Cetacean and Turtle Assessment Program. Prepared for U.S. Bureau of Land Management, Washington, D.C. by Cetacean and Turtle Assessment Program, University of Rhode Island, Graduate School of Oceanography, Kingston, Rhode Island. Contract AA551-CT8-48.

Clark, C.W. (1995) Annex M. Matters arising out of the discussion of blue whales: Annex M1. Application of US Navy underwater hydrophone arrays for scientific research on whales. Reports of the International Whaling Commission 45:210-212.

Clark, C.W. and Gagnon, G.J. (2004) Low-frequency vocal behaviors of baleen whales in the North Atlantic: Insights from Integrated Undersea Surveillance System detections, locations, and tracking from 1992 to 1996. U.S. Navy Journal of Underwater Acoustics 52(3).

Claro, R., Reshetnikov, Y.S. and Alcolado, P.M. (2002) Physical attributes of coastal Cuba. Pages 1-20 in Claro, R., Parenti, L.R. and Lindeman, K.C. (Eds) Ecology of the Marine Fishes of Cuba. Smithsonian Institution Press, Washington, D.C., USA.

Cubillas, V. (1970) Una captura insólita en Cuba. Mar y Pesca 65: 32-37.

Cuní, L.A. (1918) Contribución al estudio de mamíferos acuáticos observados en las costas de Cuba. Memorias de la Sociedad Cubana de Historia Natural "Felipe Poey" A:83123.

de la Osa, J.A. and Guma, J.G. (1971) Pilot whales captured off coast of Cuba. Translated in Pages 78-79 in Joint Publications Research Service, ed. Translations on Latin America 634.

de la Torre, C. (1907) El cachalote--Catodon macrocephalus. Anales de la Academia de Ciencias de la Habana 43:368-372.

de la Torre, D.C. (1887) Un cetáceo. Anales de la Academia de Ciencias Médicas, Físicas y Naturales de la Habana 23:431433.

Debrot, A.O. (1998) New cetacean records for Curacao, Netherlands Antilles. Caribbean Journal of Science 34(12):168-170.

Debrot, A.O., De Meyer, J.A. and Dezentjé, P.J.E. (1998) Additional records and a review of the cetacean fauna of the Leeward Dutch Antilles. Caribbean Journal of Science 34(34):204-210. 
Díaz Del Castillo, B. (1912) Works issued by the Hakluyt Society. The conquest of New Spain. Series 2. Volume 3. University of New Mexico Press, Albuquerque, New Mexico, USA.

Domning, D.P. (Ed) (1990) Distribution and status of manatees in Cuba. Sirenews 13.

Domning, D.P. (Ed) (1987) Cuba. SireNews 8.

Elliott, H.W. (1884) The monk seal of the West Indies, Monachus tropicalis Gray. Science 3:752-753. http://dx.doi.org/10.1126/science.ns-3.72.752

Erdman, D.S. (1970) Marine mammals from Puerto Rico to Antigua. Journal of Mammalogy 51(3):636-639.

Erdman, D.S., Harms, J. and Flores, M.M. (1973) Cetacean records from the northeastern Caribbean region. Cetology 17:1-14.

Espinosa, J., and Orta, J. (2007) Biota Marina. Pages 72141 in González, H.A. (Ed) Biodiversidad de Cuba, Ciudad de Guatemala.

Estrada, A.R. and Ferrer, L.T. (1987) Distribución del manatí antillano, Trichechus manatus (Mammalia: Sirenia), en Cuba. I. Región occidental. Poeyana Instituto de Zoología Academia de Ciencias de Cuba 354:1-12.

Fairbairn, P.W. and Haynes, A.M. (1982) Jamaican surveys of the West Indian manatee (Trichechus manatus), dolphin (Tursiops truncatus), sea turtles (families Cheloniidae and Dermochelydae) and booby terns (family Laridae). FAO Fisheries Report 278:289-295.

Fertl, D., Schiro, A.J., Regan, G.T., Beck, C.A., Adimey, N., Price-May, L., Amos, A., Worthy G.A.J. and Crossland, R. (2005) Manatee occurrence in the northern Gulf of Mexico, west of Florida. Gulf and Caribbean Research 17:69-94.

Firestone, J., S. B. Lyons, C. Wang and J. J. Corbett (2008) Statistical modeling of North Atlantic right whale migration along the mid-Atlantic region of the eastern seaboard of the United States. Biological Conservation 141: 221-232. http://dx.doi.org/10.1016/j.biocon.2007.09.024

Fisher, S.J. and Reeves, R.R. (2005) The global trade in live cetaceans: Implications for conservation. Journal of International Wildlife Law and Policy 8:315-340.

Fritts, T.H., Irvine, A.B., Jennings, R.D., Collum, L.A., Hoffman, W. and McGehee, M.A. (1983) Turtles, birds, and mammals in the northern Gulf of Mexico and nearby Atlantic waters. U.S. Fish and Wildlife Service FWS/OBS82/65: 455 pp. [Available from U.S. Fish and Wildlife Service, Washington, D.C., USA].

Fulling, G.L. and Clapham, P. (2004) Cruise report, NOAA Ship Gordon Gunter cruise GU-04-01(26), MONAH project humpback whale survey, Silver Bank. Unpublished cruise report. [Available from NMFS, Pascagoula, Mississippi and Woods Hole, Massachusetts, USA].
Gambell, R. (1985) Fin whale Balaenoptera physalus (Linneaus, 1758). Pages 171-192 in Ridgway, S.H. and Harrison, R. (Eds) Handbook of Marine Mammals. Volume 3: The Sirenians and Baleen Whales. Academic Press, San Diego, California, USA.

Garrison, L.P. and Richards, P.M. (2004) Estimated bycatch of marine mammals and turtles in the U.S. Atlantic pelagic longline fleet during 2003. NOAA Technical Memorandum NMFS-SEFSC-527:1-57. [PDF available from http://www. sefsc.noaa.gov/PDFdocs/PLL bycatchTechMem527.pdf].

GDAIS (General Dynamics Advanced Information Systems) (2004) The global maritime boundaries database: August 2004 Edition. from CD.

Gero, S. and Whitehead, H. (2006) Opportunistic sightings of small cetaceans off the leeward shore of the Commonwealth of Dominica. Report SC/58/SM1 presented to the Small Cetcean Subcommittee at the $58^{\text {th }}$ annual meeting of the International Whaling Commission. St. Kitts and Nevis, 16-20 June 2006. [Available from IWC Secretariat, Cambridge, UK].

González, O., Ortiz, M., Lalana, R. and Varela, C. (2001) Los crustáceos ectoparásitos de una ballena (Cetacea, Mysticeti, Balaenopteridae), encallada en la costa norte de Cuba. Revista de Investigaciones Marinas 23(1):67-68.

Gordon, J., Moscrop, A., Carlson, C., Ingram, S., Leaper, R., Matthews, J. and Young, K. (1998) Distribution, movements and residency of sperm whales off the Commonwealth of Dominica, eastern Caribbean: Implications for the development and regulation of the local whalewatching industry. Reports of the International Whaling Commission 48:551-557.

GTMO (U.S. Naval Station Guantánamo Bay). 1996. Guantanamo Bay manatee population assessment, July 1996. [Available from U.S. Naval Station Guantánamo Bay, Guantánamo, Cuba].

Hain, J.H.W., Ratnaswamy, M.J., Kenney, R.D. and Winn, H.E. (1992) The fin whale, Balaenoptera physalus, in waters of the northeastern United States continental shelf. Reports of the International Whaling Commission 42:653-669.

Harmer, S.F. (1923) Cervical vertebrae of a gigantic blue whale from Panama. Proceedings of the Zoological Society of London 1923:1085-1089.

Hersh, S.L. and Odell, D.K. (1986) Mass stranding of Fraser's dolphin, Lagenodelphis hosei, in the western North Atlantic. Marine Mammal Science 2(1):73-76. http://dx.doi.org/10.1111/j.1748-7692.1986.tb00029.x

Howe, B. (1999) Creature feature: Antillean manatees can be seen here. Guantánamo Bay Gazette (Friday, 23 July):4.

Hoyt, E. (1999) The potential of whale watching in the Caribbean: 1999+. The Whale and Dolphin Conservation Society, Bath, England, UK. [PDF available from http://www.wdcs-de.org/docs/Caribbean.pdf]. 
IUCN (International Union for Conservation of Nature) (2011) IUCN Red List of Threatened Species. Version 2011.2. Downloaded on 20 March 2012.

[Available from www.iucnredlist.org].

Jefferson, T.A. and Lynn, S.K. (1994) Marine mammal sightings in the Caribbean Sea and Gulf of Mexico, summer 1991. Caribbean Journal of Science 30(1-2):83-89.

Jefferson, T.A. and Schiro, A.J. (1997) Distribution of cetaceans in the offshore Gulf of Mexico. Mammal Review 27(1):27-50.

http://dx.doi.org/10.1111/j.1365-2907.1997.tb00371.x

Jefferson, T.A. and Curry, B.E. (2003). Stenella clymene. Mammalian Species 726:1-5.

http://dx.doi.org/10.1644/726

Jefferson, T.A., Odell, D.K. and Prunier, K.T. (1995) Notes on the biology of the Clymene dolphin (Stenella clymene) in the northern Gulf of Mexico. Marine Mammal Science 11(4):564-573.

http://dx.doi.org/10.1111/j.1748-7692.1995.tb00679.x

Jefferson, T.A., Webber, M.A. and Pitman, R.L. (2008) Marine Mammals of the World: A Comprehensive Guide to Their Identification. Academic Press, San Diego, California, USA.

Jefferson, T.A., Fertl, D., Bolaños-Jiménez, J. and Zerbini, A.N. (2009) Distribution of common dolphins (Delphinus spp.) in the western Atlantic Ocean: A critical re-examination. Marine Biology 156:1109-1124. http://dx.doi.org/10.1007/s00227-009-1152-y

Jérémie, S. (2005) Synthesis of cetaceans off the island of Martinique, French West Indies. Reference paper UNEP(DEC)/CAR WG.27/REF.7 presented at the United Nations Environment Programme Regional Workshop of Experts on the Development of the Marine Mammal Action Plan for the Wider Caribbean Region, United Nations Environment Programme, Bridgetown, Barbados, 18-21 July 2005. [PDF available from http://www.cep.unep.org/pubs/meetingreports/MMAP/].

Jérémie, S., Gannier, A., Bourreau, S. and Nicolas, J-C. (2006) Cetaceans of Martinique Island (Lesser Antilles): Occurrence and distribution obtained from a small boat dedicated survey. Paper SC/58/SM23 presented to the Scientific Committee, 58th Annual Meeting of the International Whaling Commission, St. Kitts \& Nevis, 1620 June 2006. [PDF available from http://www.iwcoffice. org/ documents/sci com/SC58docs/SC-58-SM23.pdf].

Jochens, A., Biggs, D., Benoit-Bird, K., Engelhardt, D., Gordon, J., Hu, C., Jaque, N., Johnson, M., Leben, R., Mate, B., Miller, P., Ortega-Ortiz, J., Thode, A., Tyack, P. and Würsig, B. (2008) Sperm whale seismic study in the Gulf of Mexico: Synthesis report. Prepared for U.S. Department of the Interior, Minerals Management Service, Gulf of Mexico OCS Region, New Orleans, Louisiana by Texas A\&M University, Department of Oceanography, College Station, Texas, USA. [Available from Minerals Management Service, New Orleans, LA, USA].
Kato, H. (2002) Bryde's whales Balaenoptera edeni and B. brydei. Pages 171-176 in Perrin, W.F., Würsig, B. and Thewissen, J.G.M. (Eds) Encyclopedia of Marine Mammals. Academic Press, San Diego, California, USA.

Katona, S.K. and Beard, J.A. (1991) Humpback whales (Megaptera novaeangliae) in the western North Atlantic Ocean. Memoirs of the Queensland Museum 30(2):307-321.

Katona, S.K., Beard, J.A., Girton, P.E. and Wenzel, F. (1988). Killer whales (Orcinus orca) from the Bay of Fundy to the Equator, including the Gulf of Mexico. Rit Fiskideildar $\mathrm{XI}: 205-224$

Kenney, R.D. (2001) Anomalous 1992 spring and summer right whale (Eubalaena glacialis) distributions in the Gulf of Maine. Journal of Cetacean Research and Management (Special Issue 2):209-223.

Kenney, R.D. and Winn, H.E. (1986) Cetacean high-use habitats of the northeast United States continental shelf. Fishery Bulletin 84(2):345-357.

Kenyon, K.W. (1977) Caribbean monk seal extinct. Journal of Mammalogy 58(1):97-98. http://dx.doi.org/10.2307/1379738

Knowlton, A.R., Ring, J.B. and Russell, B. (2002) Right whale sightings and survey effort in the Mid Atlantic Region: Migratory corridor, time frame, and proximity to port entrances. Report submitted to the NMFS Ship Strike Working Group, Silver Spring, Maryland. [PDF available from http://www. nero.noaa.gov/shipstrike/ssr/midatanticreportrFINAL.pdf].

Kruse, S., Caldwell, D.K. and Caldwell, M.C. (1999) Risso's dolphin Grampus griseus (G. Cuvier, 1812). Pages 183-212 in Ridgway, S.H. and Harrison, R. (Eds) Handbook of Marine Mammals. Volume 6: The Second Book of Dolphins and the Porpoises. Academic Press, San Diego, California, USA.

Leatherwood, S., Caldwell, D.K. and Winn, H.E. (1976) Whales, dolphins, and porpoises of the western North Atlantic: A guide to their identification. NOAA Technical Report NMFS CIRC-396.

Leatherwood, S., Jefferson, T.A., Norris, J.C., Stevens, W.E., Hansen, L.J. and Mullin, K.D. (1993) Occurrence and sounds of Fraser's dolphins (Lagenodelphis hosei) in the Gulf of Mexico. Texas Journal of Science 45(4):349-354.

Lefebvre, L.W., Marmontel, M., Reid, J.P., Rathbun, G.B. and Domning, D.P. (2001) Status and biogeography of the West Indian manatee. Pages 425-474 in Woods, C.A. and Sergile, F.E. (Eds) Biogeography of the West Indies: Patterns and Perspectives, 2d ed. Boca Raton, Florida: CRC Press.

León, H. and Aquayo, C.G. (1945) Excursión botánica a la bahía de Nuevas Grandes y hallazgo de una especie de cachalote nueva para la Fauna cubana. Contribuciones Ocasionales del Museo de Historia Natural del Colegio "De La Salle" 5:1-7.

Lima, O. 1989. Ballena de Boca de Galafre. Mar y Pesca. 286:17-19. 
López, N., Fernández, G., López, R., Blanco, M., Guevara, C., Sánchez, L., Cruz, D., and Sánchez, L. (2010) Los delfines y los ecosistemas costeros cubanos: perspectiva frente al cambio climático. Pages 168-175 in Hernández-Zanuy, A., and Alcolado, P.M. (Eds) La Biodiversidad en ecosistemas marinos y costeros del litoral de Iberoamérica y el cambio climático: I. Memorias del Primer Taller de la Red CYTED BIODIVMAR. Instituto de Oceanología, La Habana, Cuba.

López, N., Blanco, M., López, R., Guevara, C. and Cruz, D. (in press) Distribución, abundancia y composición etaria de los grupos de Tursiops truncatus (Cetacea: Delphinidae) en la costa norte de la provincia de Matanzas, Cuba. Revista Cubana de Ciencias Biológicas.

MacLeod, C., Perrin, W.F., Pitman, R., Barlow, J., Balance, L., D’Amico, A., Gerrodette, T., Joyce, G., Mullin, K.D., Palka, D.L. and Waring, G.T. (2006) Known and inferred distributions of beaked whale species (Cetacea: Ziphiidae). Journal of Cetacean Research and Management 7(3):271-286.

MacLeod, C.D. and Mitchell, G. (2006) Key areas for beaked whales worldwide. Journal of Cetacean Research and Management 7(3):309-322.

MacLeod, C.D., Hauser, N. and Peckham, H. (2004) Diversity, relative density and structure of the cetacean community in summer months east of Great Abaco, Bahamas. Journal of the Marine Biological Association of the United Kingdom 84:469474. http://dx.doi.org/10.1017/S0025315404009476h

Mattila, D.K. and Clapham, P.J. (1989) Humpback whales, Megaptera novaeangliae, and other cetaceans on Virgin Bank and in the northern Leeward Islands, 1985 and 1986. Canadian Journal of Zoology 67:2201-2211. http://dx.doi.org/10.1139/z89-31

Mattila, D.K., Clapham, P.J., Katona, S.K. and Stone, G.S. (1989) Population composition of humpback whales, Megaptera novaeangliae, on Silver Bank, 1984. Canadian Journal of Zoology 67:281-285.

http://dx.doi.org/10.1139/z89-041

Mattila, D.K., Clapham, P.J., Vásquez, O. and Bowman, R.S. (1994) Occurrence, population composition, and habitat use of humpback whales in Samana Bay, Dominican Republic. Canadian Journal of Zoology 72:1898-1907 http://dx.doi.org/10.1139/z94-258.

McAuslan, F., Norman, M. and Lazarus, S. (2003) The Rough Guide to Cuba. Rough Guides, London, England, UK.

Mead, J.G. (1977) Records of sei and Bryde's whales from the Atlantic coast of the United States, the Gulf of Mexico, and the Caribbean. Reports of the International Whaling Commission (Special Issue 1):113-116.

Mead, J.G. (1989) Beaked whales of the genus-Mesoplodon. Pages 349-430 in Ridgway, S.H. and Harrison, R. (Eds) Handbook of Marine Mammals. Volume 4: River Dolphins and the Larger Toothed Whales. Academic Press, London, England, UK.
Mead, J.G., Walker, W.A., Potter, C.W. and McLellan, W.A. (1986) Further observations on the life history of the melonheaded whale, Peponocephala electra. Unpublished manuscript. National Museum of Natural History, Washington, D.C., USA.

Mellinger, D.K., Nieukirk, S.L., Matsumoto, H., Heimlich, S.L., Dziak, R.P., Haxel, J., Fowler, M., Meinig, C. and Miller, H.V. (2007) Seasonal occurrence of North Atlantic right whale (Eubalaena glacialis) vocalizations at two sites on the Scotian Shelf. Marine Mammal Science 23(4):856-867. http://dx.doi.org/10.1111/j.1748-7692.2007.00144.x

Mignucci-Giannoni, A.A. (1989) Zoogeography of marine mammals in Puerto Rico and the Virgin Islands. Master's thesis. University of Rhode Island. Kingston, Rhode Island. 448 pp.

Mignucci-Giannoni, A.A. (1996) Marine mammal strandings in Puerto Rico and the United States and British Virgin Islands. Ph.D. dissertation. University of Puerto Rico. Mayagüez, Puerto Rico. 247 pp.

Mignucci-Giannoni, A.A. (1998) Zoogeography of cetaceans off Puerto Rico and the Virgin Islands. Caribbean Journal of Science 34(3-4):173-190.

Mignucci-Giannoni, A.A. and Odell, D.K. (2001) Tropical and subtropical records of hooded seals (Cystophora cristata) dispel the myth of extant Caribbean monk seals (Monachus tropicalis). Bulletin of Marine Science 68(1):47-58.

Mignucci-Giannoni, A.A. and Haddow, P. (2002) Wandering hooded seals. Science 295:627-628.

http://dx.doi.org/10.1126/science.295.5555.627

Mignucci-Giannoni, A.A., Rodríguez-López, M.A., PerezZayas, J.J., Montoya-Ospina, R.A. and Williams, Jr., E.H. (1998) First record of the melonhead whale (Peponocephala electra) for Puerto Rico. Mammalia 62(3):452-457.

Mignucci-Giannoni, A.A., Toyos-González, G.M., PérezPadilla, J., Rodríguez-López, M.A. and Overing, J. (1999a) Mass stranding of pygmy killer whales (Feresa attenuata) in the British Virgin Islands. Journal of the Marine Biological Association of the United Kingdom 80:759-760.

Mignucci-Giannoni, A.A., Montoya-Ospina, R.A., PérezZayas, J.J., Rodríguez-López, M.A. and Williams, Jr., E.H. (1999b) New records of Fraser's dolphin (Lagenodelphis hosei) for the Caribbean. Aquatic Mammals 25(1):15-19.

Mignucci-Giannoni, A.A., Swartz, S.L., Martínez, A., Burks, C.M. and Watkins, W.A. (2003) First records of the pantropical spotted dolphin (Stenella attenuata) for the Puerto Rican Bank, with a review of the species in the Caribbean. Caribbean Journal of Science 39(3):381-392.

Mitchell, E. (1975) Porpoise, Dolphin and Small Whale Fisheries of the World: Status and Problems. International Union for Conservation of Nature and Natural Resources, Morges, Switzerland.

Mitchell, E.D., Jr. (1991) Winter records of the minke whale (Balaenoptera acutorostrata acutorostrata Lacépède 1804) in the southern North Atlantic. Reports of the International Whaling Commission 41:455-457. 
Miyazaki, N. and Perrin, W.F. (1994) Rough-toothed dolphin-Steno bredanensis (Lesson, 1828). Pages 1-21 in Ridgway, S.H. and Harrison, R. (Eds) Handbook of Marine Mammals. Volume 5: The First Book of Dolphins. Academic Press, San Diego, California, USA.

Montolio Fernández, M. (2008) Stranding of dwarf sperm whale Kogia sima in Jaimanitas, at the west of Havana City. Reporte del Acuario Nacional de Cuba. La Habana, Cuba. 3 pp. [PDF available from http://www.acuarionacional.cu/ exhibiciones/imagenes/varamientoi.pdf].

Moore, J.C. (1953) Distribution of marine mammals to Florida waters. American Midland Naturalist 49:117-158.

Moore, J.C. and Clark, E. (1963) Discovery of right whales in the Gulf of Mexico. Science 141:269.

http://dx.doi.org/10.1126/science.141.3577.269

Moore, K.E., Watkins, W.A. and Tyack, P.L. (1993) Pattern similarity in shared codas from sperm whales (Physeter catodon). Marine Mammal Science 9(1):1-9.

http://dx.doi.org/10.1111/j.1748-7692.1993.tb00421.x

Morison, S.E. (1942) Chapter XXXII: Cuba and Jamaica. Pages 445-453 in Admiral of the Ocean Sea: A Life of Christopher Columbus. Little, Brown, Boston, Massachusetts, USA.

Mörzer Bruyns, W.F.J. (1969) Sight records and notes on the false killer whale, Pseudorca crassidens (Owen, 1846). Säugetierkundliche Mitteilungen 17(4):351-356.

Mullin, K.D., Jefferson, T.A., Hansen, L.J. and Hoggard, W. (1994) First sightings of melon-headed whales (Peponocephala electra) in the Gulf of Mexico. Marine Mammal Science 10(3):342-348.

http://dx.doi.org/10.1111/j.1748-7692.1994.tb00488.x

Mullin, K.D., Foley, K.M., Martinez, A. and Burks, C. (2001) NOAA Ship Gordon Gunter cruise GU-01-01 (11, Leg 3), 16 March - 3 April 2001: A study of sperm whales in the southeastern Gulf of Mexico. Unpublished cruise report. [Available from NMFS, Pascagoula, Mississippi, USA].

NMFS-SEFSC (National Marine Fisheries Service-Southeast Fisheries Science Center). (1995) Oregon II cruise 215 (9501) 26 January-11 March 1995. Unpublished cruise report. [Available from NMFS, Pascagoula, Mississippi, USA].

NMFS-SEFSC (National Marine Fisheries Service-Southeast Fisheries Science Center). (2004) Pelagic Observer Program data: 2000-2004.

[Available from http://www.sefsc.noaa.gov/observerdata.jsp].

NMFS (National Marine Fisheries Service). (2008) Endangered and threatened species: Final rule to remove the Caribbean monk seal from the federal list of endangered and threatened wildlife. Federal Register 73(209):63901-63907.

NOAA Fisheries Service. (2008) High numbers of right whales seen in Gulf of Maine: NOAA researchers identify wintering ground and potential breeding ground. Press Release. 31 December. Northeast Fisheries Science Center, Woods Hole, Massachusetts, USA. [Available from http://www.eurekalert. org/pub releases/2009-01/nnmf-hno010209.php].
O'Sullivan, S. and Mullin, K.D. (1997) Killer whales (Orcinus orca) in the northern Gulf of Mexico. Marine Mammal Science 13:141-147.

http://dx.doi.org/10.1111/j.1748-7692.1997.tb00618.x

Odell, D.K. and McClune, K.M. (1999) False killer whale Pseudorca crassidens (Owen, 1846). Pages 213-243 in Ridgway, S.H. and Harrison, R. (Eds) Handbook of Marine Mammals. Volume 6: The Second Book of Dolphins and the Porpoises. Academic Press, San Diego, California, USA.

Ortega-Ortiz, J.G. (2002) Multiscale analysis of cetacean distribution in the Gulf of Mexico. Ph.D. dissertation. Texas A\&M University, College Station, Texas, USA. 170 pp.

Ortiz, M. (1984) Hallazgo de un anfípodo ectoparásito en una ballena en aguas Cubanas. Revista de Investigaciones Marinas 5:95-96.

Ortíz, M., Lalana-R, R., and Torres-Fundora, O. (1992) Un nuevo género y una nueva especie de copépodo harpacticoida asociada al manatí Trichechus manatus en aguas Cubanas. Revista de Investigaciones Marinas 13:117-127.

Panigada, S., Notarbartolo di Sciara, G., Panigada, M.Z., Airoldi, S., Borsani, J.F. and Jahoda, M. (2005) Fin whales (Balaenoptera physalus) summering in the Ligurian Sea: Distribution, encounter rate, mean group size and relation to physiographic variables. Journal of Cetacean Research and Management 7(2):137-145.

Parente, C.L., Vergara-Parente, J.E. and Pinto de Lima, R. (2004) Strandings of Antillean manatees, Trichechus manatus manatus, in northeastern Brazil. Latin American Journal of Aquatic Mammals 3(1):69-75.

http://dx.doi.org/10.5597/lajam00050

Pérez-Cao, H. (2004) Abundancia y distribución de la tonina Tursiops truncatus (Montagu, 1821) en dos areas del Archipiélago Sabana-Camagüey, Cuba. Master's thesis. Universidad de La Habana, La Habana, Cuba. 96 pp.

Perez-Cao, H., López, N., Blanco, M., Lio, V. and GonzálezSansón, G. (2009) Abundancia y distribución del delfín (Tursiops truncatus, Montagu, 1821) en la costa norte de la Provincia Matanzas, Cuba. Revista de Investigaciones Marinas 30(1):55-61.

Perrin, W.F. and Hohn, A.A. (1994) Pantropical spotted dolphin--Stenella attenuata. Pages 71-98 in Ridgway, S.H. and Harrison, R. (Eds) Handbook of Marine Mammals. Volume 5: The First Book of Dolphins. Academic Press, San Diego, California, USA.

Perrin, W.F., Mitchell, E.D., Mead, J.G., Caldwell, D.K. and van Bree, P.J.H. (1981) Stenella clymene, a rediscovered tropical dolphin of the Atlantic. Journal of Mammalogy 62(3):583-598. http://dx.doi.org/10.2307/1380405

Perrin, W.F., Mitchell, E.D., Mead, J.G., Caldwell, D.K., Caldwell, M.C., van Bree, P.J.H. and Dawbin, W.H. (1987) Revision of the spotted dolphins, Stenella spp. Marine Mammal Science 3(2):99-170.

http://dx.doi.org/10.1111/j.1748-7692.1987.tb00158.x 
Perryman, W.L., Au, D.W.K., Leatherwood, S. and Jefferson, T.A. (1994) Melon-headed whale--Peponocephala electra (Gray, 1846). Pages 363-386 in Ridgway, S.H. and Harrison, R. (Eds) Handbook of Marine Mammals. Volume 5: The First Book of Dolphins. Academic Press, San Diego, California, USA.

Powell, J.A., Belitsky, D.W. and Rathbun, G.B. (1981) Status of the West Indian manatee (Trichechus manatus) in Puerto Rico. Journal of Mammalogy 62(3):642-646. http://dx.doi.org/10.2307/1380417

Rankin, J.J. (1953) First record of the rare beaked whale, Mesoplodon europaeus, Gervais, from the West Indies. Nature 172:873-874. http://dx.doi.org/10.1038/172873b0.

Rankin, J.J. (1956) The structure of the skull of the beaked whale, Mesoplodon gervaisi Deslongchamps. Journal of Morphology 99(2):329-357. http://dx.doi.org/10.1002/jmor.1050990205

Reeves, R.R. and Mitchell, E. (1988) Killer whale sightings and takes by American pelagic whalers in the North Atlantic. Rit Fiskideildar 11:7-23.

Reeves, R.R., Swartz, S.L., Wetmore, S.E. and Clapham, P.J. (2001) Historical occurrence and distribution of humpback whales in the eastern and southern Caribbean Sea, based on data from American whaling logbooks. Journal of Cetacean Research and Management 3(2):117-129.

Reeves, R.R., Smith, T.D., Josephson, E.A., Clapham, P.J. and Woolmer, G. (2004) Historical observations of humpback and blue whales in the North Atlantic Ocean: Clues to migratory routes and possibly additional feeding grounds. Marine Mammal Science 20(4):774-786. http://dx.doi.org/10.1111/j.1748-7692.2004.tb01192.x

Rendell, L.E. and Whitehead, H. (2003) Vocal clans in sperm whales (Physeter macrocephalus). Proceedings of the Royal Society B: Biological Sciences 270:225-231.

http://dx.doi.org/10.1098/rspb.2002.2239

Rice, D.W. (1998) Marine Mammals of the World: Systematics and Distribution. Society for Marine Mammalogy, Lawrence, Kansas, USA.

Rinaldi, C., Rinaldi R. and Sahagian, P. (2006) Report of surveys conducted on small cetaceans off Guadeloupe 1998 to 2005. Working document SC/58/SM17 presented to the IWC Scientific Committee. St. Kitts and Nevis. [Available from IWC Secretariat, Cambridge, UK].

Roca, E. and Sedaghatkish, G. (Eds) 1998. Rapid ecological assessment U.S. Naval Station Guantanamo Bay, Cuba. The Nature Conservancy, Washington, D.C., USA.

Roden, C.L. and Mullin, K.D. (2000) Sightings of cetaceans in the northern Caribbean Sea and adjacent waters, winter 1995. Caribbean Journal of Science 36(3-4):280-288.

Rodríguez-López, M.A. and Mignucci-Giannoni, A.A. (1999) A stranded pygmy killer whale (Feresa attenuata) in Puerto Rico. Aquatic Mammals 25(2):119-121.
Romero, A., Agudo, A.I., Green, S.M. and Notarbartolo di Sciara, G. (2001) Cetaceans of Venezuela: Their distribution and conservation status. NOAA Technical Report NMFS 151:1-60.

Rosario-Delestre, R.J., Rodríguez-López, M.A., MignucciGiannoni, A.A. and Mead, J.G. (1999) New records of beaked whales (Mesoplodon spp.) for the Caribbean. Caribbean Journal of Science 35(1-2):144-148.

Sanders, I.M., Barrios-Santiago, J.C. and Appeldoorn, R.S. (2005) Distribution and relative abundance of humpback whales off western Puerto Rico during 1995-1997. Caribbean Journal of Science 41(1):101-107.

Santos Mariño, J.A. (2007) Considerations about the status of the Antillean manatee (Trichechus manatus) in Cuba. Sirenews 47:21-22.

Scaramuzza, L.C. (1943) Captura de un cachalote en la costa sur de Cuba. Memorias de la Sociedad Cubana de Historia Natural 17:141-142.

Schmidly, D.J. (1981) Marine mammals of the southeastern United States coast and the Gulf of Mexico. U.S. Department of Interior, U.S. Fish and Wildlife Service Report FWS/OBS80/41: 163 pp. [Available from U.S. Fish and Wildlife Service, Washington, D.C., USA].

Schmidly, D.J., Martin, C.O. and Collins, G.F. (1972) First occurrence of a black right whale (Balaena glacialis) along the Texas coast. Southwestern Naturalist 17(2):214-215. http://dx.doi.org/10.2307/3670386

Schoenfeld, P. (2005). Creature feature: West Indian manatee. Guantánamo Bay Gazette 62(6):5.

Self-Sullivan, C. and Mignucci-Giannoni, A. (2005) Trichechus manatus manatus. IUCN Sirenia Specialist Group assessment, 2005. Report prepared for the IUCN SCC (The World Conservation Union Species Survival Commission) Red List Authority. Geneva, Switzerland.

Silva, A. (1977) Observaciones sobre la conducta alimentaria del delfín Tursiops truncatus. Miscelánea Zoológica 6:1-2.

Smith, T.D., Allen, J., Clapham, P.J., Hammond, P.S., Katona, S., Larsen, F., Lien, J., Mattila, D., Palsbøll, P.J., Sigurjónsson, J., Stevick, P.T. and Øien, N. (1999) An ocean-basin-wide mark-recapture study of the North Atlantic humpback whale (Megaptera novaeangliae). Marine Mammal Science 15(1):1-32. http://dx.doi.org/10.1111/j.1748-7692.1999.tb00779.x

Stevick, P.T., Øien, N. and Mattila, D.K. (1998) Migration of a humpback whale (Megaptera novaeangliae) between Norway and the West Indies. Marine Mammal Science 14(1):162-166. http://dx.doi.org/10.1111/j.1748-7692.1998.tb00701.x

Stevick, P.T., Allen, J., Clapham, P.J., Friday, N., Katona, S.K., Larsen, F., Lien, J., Mattila, D.K., Palsbøll, P.J., Sigurjónsson, J., Smith, T.D., Øien, N. and Hammond, P.S. (2003) North Atlantic humpback whale abundance and rate of increase four decades after protection from whaling. Marine Ecology Progress Series 258:263-273. http://dx.doi.org/10.3354/meps258263 
Swartz, S.L. and Burks, C. (2000) Cruise results: Windwards humpback (Megaptera novaeangliae) survey, NOAA Ship Gordon Gunter cruise GU-00-01 9 February to 3 April 2000. NOAA Technical Memorandum NMFS-SEFSC-438:1-31.

Taruski, A.G. and Winn, H.E. (1976) Winter sightings of odontocetes in the West Indies. Cetology 22:1-12.

Timm, R.M., Salazar, R.M. and Peterson, A.T. (1997) Historical distribution of the extinct tropical seal, Monachus tropicalis (Carnivora: Phocidae). Conservation Biology 11(2):549-551.

http://dx.doi.org/10.1046/j.1523-1739.1997.96035.x

Townsend, C.H. (1906) Capture of the West Indian seal (Monachus tropicalis) at Key West, Florida. Science 23(589):583. http://dx.doi.org/10.1126/science.23.589.583

Townsend, C.H. (1935) The distribution of certain whales as shown by logbook records of American whaleships. Zoologica $19(1): 3-50$.

True, F.W. (1889) Contributions to the natural history of the cetaceans, a review of the family Delphinidae. Bulletin of the United States National Museum 36:1-191. http://dx.doi.org/10.5479/si.03629236.36.1

UNEP (United Nations Environment Programme). (1995) Regional management plan for the West Indian manatee, Trichechus manatus. Caribbean Environment Programme Technical Report No. 35. United Nations Environment Program, Kingston, Jamaica. [PDF available from http:// www.cep.unep.org/pubs/techreports/tr35en/index.html].

van Bree, P.J.H. (1975) Preliminary list of the cetaceans of the southern Caribbean. Studies on the Fauna of Curaçao and Other Caribbean Islands 160:79-87.

van Bree, P.J.H., Creutzberg, F. and Kristensen, I. (1973) On strandings of Cuvier's whale, Ziphius cavirostris G. Cuvier, 1823, on the Lesser Antillean Islands of Sint Maarten and Curacao. Lutra 15:6-8.

van Waerebeek, K., Sequeira, M., Williamson, C., Paulo Sanino, G., Gallego, P. and Carmo, P. (2006) Live-captures of common bottlenose dolphins Tursiops truncatus and unassessed bycatch in Cuban waters: Evidence of sustainability found wanting. Latin American Journal of Aquatic Mammals 5(1):3948. http://dx.doi.org/10.5597/lajam00090

Varona, L.S. (1964) Un cráneo de Ziphius cavirostris del Sur de Isla de Pinos. Poeyana Instituto de Biologia A(4):1-3.

Varona, L.S. (1965) Balaenoptera borealis Lesson (Mammalia:Cetacea) capturada en Cuba. Poeyana Instituto de Biología 7A:1-4.

Varona, L.S. (1970) Morfología externa y caracteres craneales de un macho adulto de Mesoplodon europaeus (Cetacea: Ziphiidae). Poeyana Instituto de Biología A(69):1-17.

Varona, L.S. (1973) Catálogo de los Mamiferos Vivientes y Extinguidos de las Antillas. Academia de Ciencias de Cuba, Habana, Cuba.
Varona, L.S. (1980) Mamiferos de Cuba. Editorial Gente Nueva, Habana, Cuba.

Varona, L.S. (1985) Modificaciones ontogénicas y dimorfismo sexual en Mesoplodon gervaisi (Cetacea; Ziphiidae). Caribbean Journal of Science 21(1-2):27-37.

Varona, L.S. (2002) Mamíferos acuáticos de Cuba. Editorial Gente Nueva, Habana, Cuba.

Ward, N., Moscrop, A. and Carlson, C. (2001) Elements for the development of a marine mammal action plan for the Wider Caribbean: A review of marine mammal distribution. Havana, Cuba: United Nations Environment Programme. 77.

Watkins, W.A. and Moore, K.E. (1982) An underwater acoustic survey for sperm whales (Physeter catodon) and other cetaceans in the southeast Caribbean. Cetology 46:1-7.

Watkins, W.A., Daher, M.A., Fristrup, K. and Notarbartolo di Sciara, G. (1994) Fishing and acoustic behavior of Fraser's dolphin (Lagenodelphis hosei) near Dominica, southeast Caribbean. Caribbean Journal of Science 30(1-2):76-82.

Watkins, W.A., Daher, M.A., Samuels, A. and Gannon, D.P. (1997) Observations of Peponocephala electra, the melonheaded whale, in the southeastern Caribbean. Caribbean Journal of Science 33(1-2):34-40.

Watkins, W.A., Daher, M.A., Fristrup, K.M., Howald, T.J. and Notarbartolo di Sciara, G. (1993) Sperm whales tagged with transponders and tracked underwater by sonar. Marine Mammal Science 9(1):55-67. http://dx.doi.org/10.1111/j.1748-7692.1993.tb00426.x

Weinrich, M., Martin, M., Griffiths, R., Bove, J. and Schilling, M. (1997) A shift in distribution of humpback whales, Megaptera novaeangliae, in response to prey in the southern Gulf of Maine. Fishery Bulletin 95(4):826-836

Weir, C.R., Pollock, C., Cronin, C. and Taylor, S. (2001) Cetaceans of the Atlantic Frontier, north and west of Scotland. Continental Shelf Research 21:1047-1071.

http://dx.doi.org/10.1016/S0278-4343(00)00124-2

Wells, R.S., Early, G.A., Gannon, J.G., Lingenfelser, R.G. and Sweeney, P. (2008) Tagging and tracking of rough-toothed dolphins (Steno bredanensis) from the March 2005 mass stranding in the Florida Keys. NOAA Technical Memorandum NMFS-SEFSC-574:1-44.

Wells, R.S., Manire, C.A., Byrd, L., Smith, D.R., Gannon, J.G., Fauquier, D. and Mullin, K.D. (2009) Movements and dive patterns of a rehabilitated Risso's dolphin, Grampus griseus, in the Gulf of Mexico and Atlantic Ocean. Marine Mammal Science 25(2):420-429.

http://dx.doi.org/10.1111/j.1748-7692.2008.00251.x

Whitehead, H. (1982) Populations of humpback whales in the northwest Atlantic. Reports of the International Whaling Commission 32:345-353. 
Whitehead, H. and Moore, M.J. (1982) Distribution and movements of West Indian humpback whales in winter. Canadian Journal of Zoology 60:2203-2211. http://dx.doi.org/10.1139/z82-282

Wilson, C.E., Perrin, W.F., Gilpatrick, Jr., J.W. and Leatherwood, S. (1987) Summary of worldwide locality records of the striped dolphin, Stenella coeruleoalba. NOAA Technical Memorandum NMFS-SWFC-90:1-65.

Winn, H.E. and Perkins, P.J. (1976) Distribution and sounds of the minke whale, with a review of mysticete sounds. Cetology 19:1-12.

Winn, H.E., Edel, R.K. and Taruski, A.G. (1975) Population estimate of the humpback whale (Megaptera novaeangliae) in the West Indies by visual and acoustic techniques. Journal of the Fisheries Research Board of Canada 32(4):499-506. http://dx.doi.org/10.1139/f75-061
Winn, H.E., Price, C.A. and Sorensen, P.W. (1986) The distributional biology of the right whale (Eubalaena glacialis) in the western North Atlantic. Reports of the International Whaling Commission (Special Issue 10):129-138.

Würsig, B., Jefferson, T.A. and Schmidly, D.J. (2000) The Marine Mammals of the Gulf of Mexico. Texas A\&M University Press, College Station, Texas, USA.

Würsig, B., Lynn, S.K., Jefferson, T.A. and Mullin, K.D. (1998) Behaviour of cetaceans in the northern Gulf of Mexico relative to survey ships and aircraft. Aquatic Mammals 24(1):41-50.

Yochem, P.K. and Leatherwood, S. (1985) Blue whale Balaenoptera musculus (Linnaeus, 1758). Pages 193-240 in Ridgway, S.H. and Harrison, R. (Eds) Handbook of Marine Mammals. Volume 3: The Sirenians and Baleen Whales. San Diego, California: Academic Press. 


\section{Appendix}

Historical and recent records of marine mammals in Cuban EEZ waters through December 2008. Parentheses indicate approximate coordinates when precise ones are not known. Records are listed in order from oldest to most recent and in taxonomic order.

\begin{tabular}{|c|c|c|c|c|c|c|c|}
\hline Species/Date & Location & Position & Status $^{\mathrm{a}}$ & Type $^{\mathrm{b}}$ & $\begin{array}{c}\text { Group } \\
\text { Size }\end{array}$ & Source $^{c}$ & Comments \\
\hline \multicolumn{8}{|c|}{ LARGE WHALES } \\
\hline \multicolumn{8}{|c|}{ Megaptera novaeangliae } \\
\hline 1839 & $\begin{array}{c}\text { Punta de Maya, } \\
\text { near entrance to } \\
\text { Bahía de Mantanzas }\end{array}$ & $\left(23^{\circ} 4.91^{\prime} \mathrm{N}, 81^{\circ} 31.60^{\prime} \mathrm{W}\right)$ & $\mathrm{P}$ & Str & 1 & Cuní (1918) & Skeleton found \\
\hline 1922 & $\begin{array}{l}\text { Near Camagüey } \\
\text { Province, Gulf of } \\
\text { Ana María, close } \\
\text { to Cayo Obispo, to } \\
\text { the south of Júcaro }\end{array}$ & $\left(21^{\circ} 27.51^{\prime} \mathrm{N}, 78^{\circ} 52.15^{\prime} \mathrm{W}\right)$ & $\mathrm{P}$ & Cap & 1 & Scaramuzza (1943) & $\begin{array}{l}\text { Author refers to this animal as a } \\
\text { "Finback", but the footnote in } \\
\text { the article states that this animal } \\
\text { was probably a humpback whale }\end{array}$ \\
\hline Dec 1932 & $\begin{array}{c}20 \text { miles off } \\
\text { Habana }\end{array}$ & $\left(23^{\circ} 10^{\prime} \mathrm{N}, 83^{\circ} 05^{\prime} \mathrm{W}\right)$ & $\mathrm{P}$ & Sig & 1 & Aguayo (1954) & \\
\hline 1986 & Jibara, Holguín & $\left(21^{\circ} 06.58^{\prime} \mathrm{N}, 76^{\circ} 07.09^{\prime} \mathrm{W}\right)$ & $\mathrm{C}$ & Str & 1 & Guitart $^{\mathrm{d}}$ & \\
\hline June 1997 & $\begin{array}{l}\text { Bahía de Cádiz, (3 } \\
\text { miles from Faro) } \\
\text { Villa Clara }\end{array}$ & $\left(23^{\circ} 12^{\prime} \mathrm{N}, 80^{\circ} 29^{\prime} \mathrm{W}\right)$ & $\mathrm{P}$ & Sig & 1 & Blanco $(2008)^{e}$ & \\
\hline 13 Jan 1999 & $\begin{array}{l}\text { Near Boca de } \\
\text { Jaruco, east of } \\
\text { Habana }\end{array}$ & $\left(23^{\circ} 11.30^{\prime} \mathrm{N}, 82^{\circ} 1.28^{\prime} \mathrm{W}\right)$ & $\mathrm{C}$ & Sig & 1 & $\begin{array}{l}\text { Radio Havana } \\
\text { Cuba f,g; Blanco, M., } \\
\text { pers. obs. }\end{array}$ & $\begin{array}{l}\text { Whale was ca. 9m and 19tons } \\
\text { and was sighted for six days } \\
\text { before it stranded; photograph } \\
\text { taken }\end{array}$ \\
\hline 15 Feb 2000 & Cayo Coco & $\left(22^{\circ} 31.55^{\prime} \mathrm{N}, 78^{\circ} 31.30^{\circ} \mathrm{W}\right)$ & $\mathrm{P}$ & Str & 1 & $\begin{array}{l}\text { González et al. } \\
(2001)\end{array}$ & $\begin{array}{c}\text { Whale may have been harpooned } \\
\text { offshore before stranding }\end{array}$ \\
\hline Jun 2000 & $\begin{array}{c}\text { One mile } \\
\text { away from the } \\
\text { Guajímico tourist } \\
\text { villa (between } \\
\text { Cienfuegos and } \\
\text { Trinidad) }\end{array}$ & $\left(21^{\circ} 54.38^{\prime} \mathrm{N}, 80^{\circ} 19.07^{\prime} \mathrm{W}\right)$ & $\mathrm{P}$ & Sig & 12 & $\begin{array}{l}\text { Radio Havana } \\
\text { Cuba }^{\mathrm{h}}\end{array}$ & \\
\hline Jul 2002 & $\begin{array}{l}\text { Punta Tiburón, } \\
\text { Cayo Coco, Ciego } \\
\text { de Ávila Province } \\
\end{array}$ & $\left(22^{\circ} 33^{\prime} \mathrm{N}, 78^{\circ} 27^{\prime} \mathrm{W}\right)$ & $\mathrm{C}$ & Str & 1 & Blanco $(2008)^{\mathrm{i}}$ & \\
\hline $7 \mathrm{Jul} 2002$ & $\begin{array}{l}\text { Cayo Coco, Ciego } \\
\text { de Ávila Province }\end{array}$ & $22^{\circ} 33^{\prime} \mathrm{N}, 78^{\circ} 27^{\prime} \mathrm{W}$ & $\mathrm{C}$ & Sig & 2 & Blanco $(2008)^{\mathrm{i}}$ & \\
\hline 30 Dec 2004 & $\begin{array}{l}\text { Along the shoreline } \\
\text { of Habana }\end{array}$ & $23^{\circ} 13.96^{\prime} \mathrm{N}, 82^{\circ} 26.40^{\circ} \mathrm{W}$ & $\mathrm{P}$ & Sig & 1 & Blanco $(2008)^{j}$ & \\
\hline 1 Jan 2005 & $\begin{array}{l}\text { Punta Seboruco, } \\
\text { Matanzas }\end{array}$ & $\left(23^{\circ} 13.09^{\prime} \mathrm{N}, 81^{\circ} 34.65^{\prime} \mathrm{W}\right)$ & $\mathrm{P}$ & Sig & 1 & Blanco $(2008)^{i}$ & \\
\hline 17 Apr 2006 & $\begin{array}{l}3 \text { miles from Playa } \\
\text { Salado, La Habana }\end{array}$ & $\left(23^{\circ} 04^{\prime} \mathrm{N}, 82^{\circ} 40^{\prime} \mathrm{W}\right)$ & $\mathrm{P}$ & Sig & 2 & Blanco $(2008)^{\mathrm{k}}$ & \\
\hline Mar 2008 & Baracoa & $\left(20^{\circ} 30^{\prime} \mathrm{N}, 74^{\circ} 38^{\prime} \mathrm{W}\right)$ & $\mathrm{C}$ & Sig & 2 & Soler Costafreda ${ }^{1}$ & \\
\hline \multicolumn{8}{|c|}{ Balaenoptera edenilbrydei } \\
\hline 3 Jan 1963 & $\begin{array}{l}\text { Ensenada de Mora, } \\
\text { east of Cabo Cruz, } \\
\text { Oriente Province }\end{array}$ & $\left(19^{\circ} 52.51^{\prime} \mathrm{N}, 77^{\circ} 19^{\prime} \mathrm{W}\right)$ & $\mathrm{C}$ & Cap & 1 & $\begin{array}{l}\text { Varona (1965); } \\
\text { Mead (1977) }\end{array}$ & $10.28 \mathrm{~m}$ juvenile $\mathrm{e}^{\mathrm{m}}$ \\
\hline \multicolumn{8}{|c|}{ Balaenoptera physalus } \\
\hline Jul 1989 & $\begin{array}{l}\text { Boca de Galafre, } \\
\text { Pinar del Rio }\end{array}$ & $\left(22^{\circ} 12^{\prime} \mathrm{N}, 83^{\circ} 59^{\prime} \mathrm{W}\right)$ & $\mathrm{C}$ & Str & 1 & $\begin{array}{l}\text { Lima (1989); } \\
\text { Blanco (2008) }\end{array}$ & $19.80 \mathrm{~m}$; photographs taken \\
\hline \multicolumn{8}{|c|}{ Balaenoptera spp. } \\
\hline Dec 1970 & $\begin{array}{c}\text { Cayo Punta } \\
\text { Mujeres, Villa Clara }\end{array}$ & $\left(23^{\circ} 06^{\prime} \mathrm{N}, 80^{\circ} 27^{\prime} \mathrm{W}\right)$ & $\mathrm{C}$ & Cap & 1 & Cubillas (1970) & $15 \mathrm{~m}$; photographs taken \\
\hline \multicolumn{8}{|c|}{ Unidentified rorqual } \\
\hline Feb 1975 & $\begin{array}{l}\text { Playa Mar Verde, } \\
\text { Santiago de Cuba }\end{array}$ & $\left(19^{\circ} 59^{\prime} \mathrm{N}, 75^{\circ} 49^{\prime} \mathrm{W}\right)$ & $\mathrm{C}$ & Str & 1 & Blanco $(2008)^{\mathrm{n}}$ & $10.27 \mathrm{~m}$ \\
\hline 18 Apr 1989 & $\begin{array}{l}90 \mathrm{~km} \text { south of Key } \\
\text { West, Florida }\end{array}$ & $23^{\circ} 45^{\prime} \mathrm{N}, 81^{\circ} 54^{\prime} \mathrm{W}$ & $\mathrm{C}$ & N/A & 1 & USNM & \\
\hline \multicolumn{8}{|c|}{ Physeter macrocephalus } \\
\hline $\mathrm{N} / \mathrm{A}$ & $\begin{array}{l}\text { Off northeast coast } \\
\text { of Cuba }\end{array}$ & $21^{\circ} 40^{\prime} \mathrm{N}, 76^{\circ} 28^{\prime} \mathrm{W}$ & $\mathrm{P}$ & Sig & N/A & Schmidly (1981) & \\
\hline $\begin{array}{l}\text { Between } 1752 \\
\text { and } 1902\end{array}$ & Straits of Florida & $\left(25^{\circ} 30^{\prime} \mathrm{N}, 86^{\circ} 26^{\prime} \mathrm{W}\right)$ & $\mathrm{P}$ & Cap & $\mathrm{N} / \mathrm{A}$ & $\begin{array}{l}\text { Townsend (1935); } \\
\text { Schmidly (1981) }\end{array}$ & \\
\hline $\begin{array}{l}\text { Between } 1752 \\
\text { and } 1902\end{array}$ & Straits of Florida & $\left(24^{\circ} 48^{\prime} \mathrm{N}, 86^{\circ} 38^{\prime} \mathrm{W}\right)$ & $\mathrm{P}$ & Cap & N/A & $\begin{array}{l}\text { Townsend (1935); } \\
\text { Schmidly (1981) }\end{array}$ & \\
\hline
\end{tabular}




\begin{tabular}{|c|c|c|c|c|c|c|c|}
\hline Species/Date & Location & Position & Status $^{\mathrm{a}}$ & Type $^{b}$ & $\begin{array}{l}\text { Group } \\
\text { Size }\end{array}$ & Source $^{c}$ & Comments \\
\hline $\begin{array}{c}\text { Between } 1752 \\
\text { and } 1902 \\
\end{array}$ & Straits of Florida & $\left(23^{\circ} 44^{\prime} \mathrm{N}, 86^{\circ} 50^{\prime} \mathrm{W}\right)$ & $\mathrm{P}$ & Cap & N/A & $\begin{array}{l}\text { Townsend (1935); } \\
\text { Schmidly (1981) }\end{array}$ & \\
\hline $\begin{array}{c}\text { Between } 1752 \\
\text { and } 1902 \\
\end{array}$ & Straits of Florida & $\left(23^{\circ} 34^{\prime} \mathrm{N}, 86^{\circ} 00^{\prime} \mathrm{W}\right)$ & $\mathrm{P}$ & Cap & N/A & $\begin{array}{l}\text { Townsend (1935); } \\
\text { Schmidly (1981) }\end{array}$ & \\
\hline $\begin{array}{c}\text { Between } 1752 \\
\text { and } 1902 \\
\end{array}$ & Straits of Florida & $\left(23^{\circ} 50^{\prime} \mathrm{N}, 81^{\circ} 47^{\prime} \mathrm{W}\right)$ & $\mathrm{P}$ & Cap & N/A & $\begin{array}{l}\text { Townsend (1935); } \\
\text { Schmidly (1981) }\end{array}$ & \\
\hline $\begin{array}{c}\text { Between } 1752 \\
\text { and } 1902\end{array}$ & Straits of Florida & $\left(23^{\circ} 49^{\prime} \mathrm{N}, 81^{\circ} 10^{\prime} \mathrm{W}\right)$ & $\mathrm{P}$ & Cap & N/A & $\begin{array}{l}\text { Townsend (1935); } \\
\text { Schmidly (1981) }\end{array}$ & \\
\hline $\begin{array}{c}\text { Between } 1752 \\
\text { and } 1902 \\
\end{array}$ & Straits of Florida & $\left(23^{\circ} 70^{\prime} \mathrm{N}, 81^{\circ} 25^{\prime} \mathrm{W}\right)$ & $\mathrm{P}$ & Cap & N/A & $\begin{array}{l}\text { Townsend (1935); } \\
\text { Schmidly (1981) }\end{array}$ & \\
\hline $\begin{array}{c}\text { Between } 1752 \\
\text { and } 1902 \\
\end{array}$ & Straits of Florida & $\left(21^{\circ} 41^{\prime} \mathrm{N}, 76^{\circ} 28^{\prime} \mathrm{W}\right)$ & $\mathrm{P}$ & Cap & N/A & $\begin{array}{l}\text { Townsend (1935); } \\
\text { Schmidly (1981) }\end{array}$ & \\
\hline 3 Jan 1830 & $\begin{array}{l}4 \text { miles offshore of } \\
\text { El Frayle } \\
\text { (Playa El Fraile) }\end{array}$ & $\left(23^{\circ} 09^{\prime} \mathrm{N}, 81^{\circ} 52^{\prime} \mathrm{W}\right)$ & $\mathrm{P}$ & Sig & 1 & Cuní (1918) & \\
\hline 1897 & Bahía de Matanzas & $\left(23^{\circ} 40^{\prime} \mathrm{N}, 81^{\circ} 30^{\prime} \mathrm{W}\right)$ & $\mathrm{P}$ & Str & 1 & de la Torre (1907) & Small whale-ca. $15 \mathrm{~m}$ \\
\hline May 1906 & $\begin{array}{l}\text { Between Cayo } \\
\text { Confites and Cayo } \\
\text { Romano in the } \\
\text { narrowest part of } \\
\text { Canal del Viejo } \\
\text { de Bahamas (Old } \\
\text { Bahama Channel) }\end{array}$ & $\left(22^{\circ} 01^{\prime} \mathrm{N}, 77^{\circ} 39^{\prime} \mathrm{W}\right)$ & $\mathrm{P}$ & Str & 1 & de la Torre (1907) & $\begin{array}{l}25 \mathrm{~m} \text {; complete skeleton taken } \\
\text { to Habana }\end{array}$ \\
\hline 1907 & $\begin{array}{c}\text { Between Cayo } \\
\text { Confites and Cayo } \\
\text { Romano }\end{array}$ & $\left(22^{\circ} 01^{\prime} \mathrm{N}, 77^{\circ} 39^{\prime} \mathrm{W}\right)$ & $\mathrm{P}$ & Str & 1 & Cuní (1918) & Skeleton found on 1 May 1907 \\
\hline ca. 1909 & Cuba & N/A & $\mathrm{P}$ & Str & 1 & Cuní (1918) & Skeleton found in Jun 1909 \\
\hline 1940 & $\begin{array}{l}\text { Bahía de Gibara, } \\
\text { Holguín }\end{array}$ & $\left(21^{\circ} 05.29^{\prime} \mathrm{N}, 76^{\circ} 07.12^{\prime} \mathrm{W}\right)$ & $\mathrm{P}$ & Str & 1 & \begin{tabular}{|c|} 
Blanco \\
Domínguez (2011) \\
(identification by A. \\
Lemus Nicollau) \\
\end{tabular} & $13 \mathrm{~m}$ long \\
\hline 19 Feb 1943 & $\begin{array}{l}\text { Near Camagüey } \\
\text { Province, Gulf of } \\
\text { Ana María, close } \\
\text { to Cayo Obispo, to } \\
\text { the south of Júcaro }\end{array}$ & $\left(21^{\circ} 30.62^{\prime} \mathrm{N}, 78^{\circ} 53.13^{\prime} \mathrm{W}\right)$ & $\mathrm{P}$ & Sig & 1 & Scaramuzza (1943) & $\begin{array}{c}\text { Whale was later captured and } \\
\text { brought to the harbor in Puerto } \\
\text { de Júcaro }\end{array}$ \\
\hline Mar 1978 & Guantánamo Bay & $\left(19^{\circ} 54^{\prime} \mathrm{N}, 75^{\circ} 90^{\prime} \mathrm{W}\right)$ & $\mathrm{C}$ & Str & 1 & Blanco (in press) ${ }^{o, n}$ & $\begin{array}{l}15 \mathrm{~m} \text { male; skeleton currently on } \\
\text { display at the Museo de Historia } \\
\text { Natural de Santiago de Cuba } \\
\text { (Tomás Romay Museum) }\end{array}$ \\
\hline Mar 1986 & Holguín & $\left(21^{\circ} 12^{\prime} \mathrm{N}, 75^{\circ} 42^{\prime} \mathrm{W}\right)$ & $\mathrm{C}$ & Str & 1 & Blanco (in press) ${ }^{\mathrm{d}}$ & \\
\hline May 1989 & $\begin{array}{l}\text { El Cuero, } \\
\text { Santiago de } \\
\text { Cuba }\end{array}$ & $\left(20^{\circ} 01^{\prime} \mathrm{N}, 75^{\circ} 49^{\prime} \mathrm{W}\right)$ & $\mathrm{C}$ & Str & 1 & Blanco (in press) ${ }^{\mathrm{n}}$ & $3.10 \mathrm{~m}$ juvenile female \\
\hline Nov 1989 & $\begin{array}{c}\text { Cabo Cruz, } \\
\text { Granma }\end{array}$ & $\left(19^{\circ} 55^{\prime} \mathrm{N}, 77^{\circ} 13^{\prime} \mathrm{W}\right)$ & $\mathrm{C}$ & Str & 1 & Blanco (in press) ${ }^{\mathrm{n}}$ & \\
\hline 8 Jun 1991 & $\begin{array}{l}\text { Off northern coast } \\
\text { of Cuba }\end{array}$ & $22^{\circ} 06^{\prime} \mathrm{N}, 77^{\circ} 25^{\prime} \mathrm{W}$ & $\mathrm{P}$ & Sig & 4 & $\begin{array}{l}\text { Jefferson and Lynn } \\
\text { (1994) }\end{array}$ & \\
\hline 8 Jun 1992 & $\begin{array}{l}\text { Off northwestern } \\
\text { coast of Cuba }\end{array}$ & $22^{\circ} 34.40^{\prime} \mathrm{N}, 84^{\circ} 38.10^{\prime} \mathrm{W}$ & $\mathrm{C}$ & Sig & $>1$ & $\begin{array}{c}\text { Hal Whitehead } \\
\text { unpub. data }\end{array}$ & Whales also detected acoustically \\
\hline 15 Nov 1995 & $\begin{array}{c}\text { Off southern coast } \\
\text { of Cuba }\end{array}$ & $\left(21^{\circ} 26.15^{\prime} \mathrm{N}, 81^{\circ} 38.10^{\prime} \mathrm{W}\right)$ & $\mathrm{P}$ & Sig & 5 & Blanco (in press) ${ }^{\mathrm{p}}$ & \\
\hline 1996 & $\begin{array}{l}\text { Cárdenas, } \\
\text { Matanzas } \\
\end{array}$ & $\left(23^{\circ} 06^{\circ} \mathrm{N}, 81^{\circ} 06 \mathrm{~W}\right)$ & $\mathrm{C}$ & Str & 1 & Blanco (in press) ${ }^{d}$ & \\
\hline Feb 1996 & $\begin{array}{c}\text { Cienaga/Peninsula } \\
\text { de Zapata, } \\
\text { Matanzas } \\
\end{array}$ & $\left(22^{\circ} 16.35^{\prime} \mathrm{N}, 81^{\circ} 12.55^{\prime} \mathrm{W}\right)$ & $\mathrm{C}$ & Str & 1 & $\begin{array}{c}\text { Blanco, M., pers. } \\
\text { obs.; Blanco (in } \\
\text { press) }\end{array}$ & \\
\hline 1999 & $\begin{array}{l}\text { Near mouth of } \\
\text { Guantánamo Bay }\end{array}$ & $\left(19^{\circ} 53.85^{\prime} \mathrm{N}, 75^{\circ} 10.96^{\prime} \mathrm{W}\right)$ & $\mathrm{P}$ & Sig & $>1$ & GTMO unpub. data & \\
\hline Oct 2000 & $\begin{array}{l}\text { Cayo Francés, } \\
\text { Villa Clara }\end{array}$ & $\left(22^{\circ} 32^{\prime} \mathrm{N}, 79^{\circ} 20^{\prime} \mathrm{W}\right)$ & $\mathrm{C}$ & Str & 1 & $\begin{array}{l}\text { Blanco, M., pers. } \\
\text { obs.; Blanco (in } \\
\text { press) }\end{array}$ & $3.5 \mathrm{~m}$ juvenile female \\
\hline 22 Mar 2002 & $\begin{array}{l}\text { Off Trinidad, } \\
\text { Sancti Spiritus }\end{array}$ & $\left(21^{\circ} 29.08^{\prime} \mathrm{N}, 79^{\circ} 27.10^{\prime} \mathrm{W}\right)$ & $\mathrm{P}$ & Sig & 1 & Blanco (in press) ${ }^{\mathrm{p}}$ & \\
\hline 21 Nov 2003 & $\begin{array}{l}\text { Off northwestern } \\
\text { coast of Cuba }\end{array}$ & $23^{\circ} 4.26^{\prime} \mathrm{N}, 83^{\circ} 9.66^{\prime} \mathrm{W}$ & $\mathrm{C}$ & Det & 1 & $\begin{array}{l}\text { Bruce Mate unpub. } \\
\text { data }\end{array}$ & Tagged individual \#2505725 \\
\hline
\end{tabular}




\begin{tabular}{|c|c|c|c|c|c|c|c|}
\hline Species/Date & Location & Position & Status $^{a}$ & Type $^{\mathrm{b}}$ & $\begin{array}{c}\text { Group } \\
\text { Size }\end{array}$ & Source $^{c}$ & Comments \\
\hline 22 Nov 2003 & $\begin{array}{l}\text { Off northwestern } \\
\text { coast of Cuba }\end{array}$ & $23^{\circ} 0.24^{\prime} \mathrm{N}, 83^{\circ} 13.98^{\prime} \mathrm{W}$ & $\mathrm{C}$ & Det & 1 & $\begin{array}{c}\text { Bruce Mate unpub. } \\
\text { data }\end{array}$ & Tagged individual \#2505725 \\
\hline 25 Nov 2003 & $\begin{array}{l}\text { Off northwestern } \\
\text { coast of Cuba }\end{array}$ & $23^{\circ} 2.94^{\prime} \mathrm{N}, 83^{\circ} 56.64^{\prime} \mathrm{W}$ & C & Det & 1 & $\begin{array}{l}\text { Bruce Mate unpub. } \\
\text { data }\end{array}$ & Tagged individual \#2505725 \\
\hline 25 Nov 2003 & $\begin{array}{l}\text { Off northwestern } \\
\text { coast of Cuba }\end{array}$ & $22^{\circ} 58.14^{\prime} \mathrm{N}, 83^{\circ} 45.96^{\circ} \mathrm{W}$ & $\mathrm{C}$ & Det & 1 & $\begin{array}{l}\text { Bruce Mate unpub. } \\
\text { data }\end{array}$ & Tagged individual $\# 2505725$ \\
\hline 29 Nov 2003 & $\begin{array}{l}\text { Off northwestern } \\
\text { coast of Cuba }\end{array}$ & $22^{\circ} 49.44^{\prime} \mathrm{N}, 84^{\circ} 13.44^{\prime} \mathrm{W}$ & C & Det & 1 & $\begin{array}{c}\text { Bruce Mate unpub. } \\
\text { data }\end{array}$ & Tagged individual \#2505725 \\
\hline 29 Nov 2003 & $\begin{array}{l}\text { Off northwestern } \\
\text { coast of Cuba }\end{array}$ & $22^{\circ} 30.66^{\prime} \mathrm{N}, 84^{\circ} 33.84^{\prime} \mathrm{W}$ & C & Det & 1 & $\begin{array}{c}\text { Bruce Mate unpub. } \\
\text { data }\end{array}$ & Tagged individual \#2505725 \\
\hline 7 Dec 2003 & $\begin{array}{l}\text { Off northwestern } \\
\text { coast of Cuba }\end{array}$ & $23^{\circ} 3.42^{\prime} \mathrm{N}, 83^{\circ} 16.98^{\prime} \mathrm{W}$ & $\mathrm{C}$ & Det & 1 & $\begin{array}{l}\text { Bruce Mate unpub. } \\
\text { data }\end{array}$ & Tagged individual \#2505725 \\
\hline 10 Dec 2003 & $\begin{array}{l}\text { Off northwestern } \\
\text { coast of Cuba }\end{array}$ & $23^{\circ} 3.84^{\prime} \mathrm{N}, 83^{\circ} 59.52^{\prime} \mathrm{W}$ & $\mathrm{C}$ & Det & 1 & $\begin{array}{c}\text { Bruce Mate unpub. } \\
\text { data }\end{array}$ & Tagged individual $\# 2505725$ \\
\hline 11 Dec 2003 & $\begin{array}{l}\text { Off northwestern } \\
\text { coast of Cuba }\end{array}$ & $23^{\circ} 0^{\prime} \mathrm{N}, 83^{\circ} 39.78^{\prime} \mathrm{W}$ & C & Det & 1 & $\begin{array}{l}\text { Bruce Mate unpub. } \\
\text { data }\end{array}$ & Tagged individual \#2505725 \\
\hline 18 Sept 2005 & $\begin{array}{c}\text { ca. } 1 \text { mile offshore } \\
\text { of GTMO } \\
\text { (windward side) }\end{array}$ & $\left(19^{\circ} 52.60^{\prime} \mathrm{N}, 75^{\circ} 8.36^{\prime} \mathrm{W}\right)$ & $\mathrm{C}$ & Sig & $>1$ & $\begin{array}{l}\text { GTMO unpub. } \\
\text { data }\end{array}$ & \\
\hline Feb 2006 & $\begin{array}{c}\text { El Cuero, } \\
\text { Santiago de Cuba }\end{array}$ & $\left(20^{\circ} 01^{\prime} \mathrm{N}, 75^{\circ} 49^{\prime} \mathrm{W}\right)$ & C & Str & 1 & Blanco (in press) ${ }^{9}$ & $15 \mathrm{~m}$ female \\
\hline Mar 2006 & $\begin{array}{c}\text { Cayo Coco, Ciego } \\
\text { de Âvila }\end{array}$ & $\left(22^{\circ} 33^{\prime} \mathrm{N}, 78^{\circ} 27^{\prime} \mathrm{W}\right)$ & $\mathrm{C}$ & Str & 1 & $\begin{array}{l}\text { Blanco, M., Pina, } \\
\text { F., and Moré, D. } \\
\text { pers. obs.; Blanco } \\
\quad \text { (in press) }\end{array}$ & $14.6 \mathrm{~m}$; photographs taken \\
\hline May 2006 & $\begin{array}{l}\text { Playa el Cuero, } \\
\text { Guamá, Santiago } \\
\text { de Cuba }\end{array}$ & $\left(19^{\circ} 56^{\prime} \mathrm{N}, 76^{\circ} 48^{\prime} \mathrm{W}\right)$ & $\mathrm{C}$ & Str & 1 & $\begin{array}{l}\text { Lauranzon } \\
\text { Meléndez }^{\circ}\end{array}$ & $\begin{array}{c}\text { Skeleton currently on display at } \\
\text { the Museo de Historia Natural } \\
\text { de Santiago de Cuba (Tomás } \\
\text { Romay Museum) }\end{array}$ \\
\hline Feb 2008 & $\begin{array}{c}\text { Punta Tabacal, } \\
\text { Chivirico, Santiago } \\
\text { de Cuba }\end{array}$ & $\left(19^{\circ} 57.60^{\prime} \mathrm{N}, 76^{\circ} 21.24^{\prime} \mathrm{W}\right)$ & $\mathrm{C}$ & Str & 1 & $\begin{array}{l}\text { Lauranzon } \\
\text { Meléndez }^{\circ}\end{array}$ & $\begin{array}{c}\text { Skeleton of this juvenile } \\
\text { currently on display at the } \\
\text { Museo de Historia Natural } \\
\text { de Santiago de Cuba (Tomás } \\
\text { Romay Museum) }\end{array}$ \\
\hline 29 Mar 2008 & $\begin{array}{c}\text { Punta de Maya, } \\
\text { Matanzas }\end{array}$ & $\left(23^{\circ} 11.08^{\prime} \mathrm{N}, 81^{\circ} 27.11^{\prime} \mathrm{W}\right)$ & $\mathrm{C}$ & Sig & 1 & $\begin{array}{l}\text { Blanco, M., López, } \\
\text { N., and López, R. } \\
\text { pers. obs.; Blanco } \\
\text { (in press) } \\
\end{array}$ & Photographs taken \\
\hline \multicolumn{8}{|c|}{ Unidentified large whale } \\
\hline 6 May 1970 & $\begin{array}{c}\text { Offshore of } \\
\text { Guantánamo Bay }\end{array}$ & $19^{\circ} 50^{\prime} \mathrm{N}, 75^{\circ} 10^{\prime} \mathrm{W}$ & C & Sig & 2 & CETAP $(1982)^{\mathrm{r}}$ & \\
\hline \multicolumn{8}{|c|}{ Unidentified whale } \\
\hline 1970 & $\begin{array}{l}\text { La Panchita Beach, } \\
\text { northern coast of } \\
\text { the Villa Clara } \\
\text { Province }\end{array}$ & $\left(22^{\circ} 56.99^{\prime} \mathrm{N}, 80^{\circ} 24.92^{\prime} \mathrm{W}\right)$ & C & Str & 1 & Ortiz (1984) & \\
\hline
\end{tabular}




\begin{tabular}{|c|c|c|c|c|c|c|c|}
\hline $\begin{array}{l}\text { Species/Date } \\
\text { KOGIIDAE }\end{array}$ & Location & Position & Status $^{\mathrm{a}}$ & Type $^{b}$ & $\begin{array}{l}\text { Group } \\
\text { Size }\end{array}$ & Source $^{c}$ & Comments \\
\hline \multicolumn{8}{|l|}{ Kogia breviceps } \\
\hline 1937 & $\begin{array}{c}\text { Bahía de Nuevas } \\
\text { Grandes }\end{array}$ & $\left(21^{\circ} 27.36^{\prime} \mathrm{N}, 76^{\circ} 56.96^{\prime} \mathrm{W}\right)$ & $\mathrm{C}$ & Str & 1 & $\begin{array}{l}\text { Aguayo (1954); } \\
\text { Varona (1980) }\end{array}$ & $\begin{array}{l}\text { Skull said to be kept at the } \\
\text { museum at the Colegio de la } \\
\text { Salle }\end{array}$ \\
\hline Jun 1954 & Manatí, Matanzas & $\left(22^{\circ} 16^{\prime} \mathrm{N}, 81^{\circ} 13^{\prime} \mathrm{W}\right)$ & $\mathrm{C}$ & Str & 1 & $\begin{array}{l}\text { Blanco Domínguez } \\
\text { (2011) }\end{array}$ & \\
\hline 2002 & $\begin{array}{c}\text { Playa Larga, } \\
\text { Santiago de Cuba }\end{array}$ & $\left(19^{\circ} 53.39^{\prime} \mathrm{N}, 75^{\circ} 33.35^{\prime} \mathrm{W}\right)$ & $\mathrm{C}$ & Str & 1 & $\begin{array}{l}\text { Lauranzon } \\
\text { Meléndez }^{\circ}\end{array}$ & $\begin{array}{c}\text { Skeleton currently on display at } \\
\text { the Museo de Historia Natural } \\
\text { de Santiago de Cuba (Tomás } \\
\text { Romay Museum) }\end{array}$ \\
\hline May 2005 & Bahía de La Habana & $\left(23^{\circ} 08.53^{\prime} \mathrm{N}, 82^{\circ} 22.30^{\prime} \mathrm{W}\right)$ & $\mathrm{C}$ & Str & 1 & Guitart $^{\mathrm{d}}$ & \\
\hline \multicolumn{8}{|l|}{ Kogia sima } \\
\hline 1977 & $\begin{array}{l}\text { Regla, Bahía de La } \\
\text { Habana, Habana }\end{array}$ & $\left(23^{\circ} 07.90^{\prime} \mathrm{N}, 82^{\circ} 20.20^{\prime} \mathrm{W}\right)$ & $\mathrm{C}$ & Str & 1 & Varona (1980) & $2.5 \mathrm{~m}$ long \\
\hline Feb 2004 & $\begin{array}{c}\text { Playa Baconao, } \\
\text { Santiago de Cuba }\end{array}$ & $\left(19^{\circ} 56.44^{\prime} \mathrm{N}, 75^{\circ} 41.62^{\prime} \mathrm{W}\right)$ & $\mathrm{C}$ & Str & 1 & Tamaños $^{s}$ & $2.5 \mathrm{~m}$ long \\
\hline Sept 2007 & $\begin{array}{c}\text { Playa Larga, } \\
\text { Santiago de Cuba }\end{array}$ & $\left(19^{\circ} 53.47^{\prime} \mathrm{N}, 75^{\circ} 34.14^{\prime} \mathrm{W}\right)$ & $\mathrm{C}$ & Str & 1 & Romero $^{t}$ & \\
\hline 25 Aug 2008 & $\begin{array}{l}\text { Near the Círculo } \\
\text { Social Obrero } \\
\text { Los Marinos en } \\
\text { Jaimanitas, western } \\
\text { Habana }\end{array}$ & $\left(23^{\circ} 05.51^{\prime} \mathrm{N}, 82^{\circ} 28.66^{\prime} \mathrm{W}\right)$ & $\mathrm{C}$ & Str & 1 & $\begin{array}{l}\text { Montolio Fernández } \\
\text { (2008) }\end{array}$ & $1.95 \mathrm{~m}$ long \\
\hline \multicolumn{8}{|l|}{ Kogia spp. } \\
\hline N/A & $\begin{array}{c}\text { Ensenada de la } \\
\text { Herradura }\end{array}$ & $\left(23^{\circ} 1.29^{\prime} \mathrm{N}, 83^{\circ} 2.63^{\prime} \mathrm{W}\right)$ & $\mathrm{C}$ & Str & 1 & $\begin{array}{l}\text { León and Aguayo } \\
\qquad(1945)\end{array}$ & Skeleton recorded \\
\hline 10 Dec 1999 & $\begin{array}{c}\text { Between Piers } \\
\text { Alpha, Cima and } \\
\text { Buckley Landing, } \\
\text { GTMO }\end{array}$ & $\left(19^{\circ} 55.06^{\prime} \mathrm{N}, 75^{\circ} 8.83^{\prime} \mathrm{W}\right)$ & $\mathrm{C}$ & Str & 1 & $\begin{array}{l}\text { GTMO unpub. } \\
\text { data }\end{array}$ & \\
\hline Dec 2006 & $\begin{array}{c}\text { Punta Francés, Isla } \\
\text { de la Juventud }\end{array}$ & $\left(21^{\circ} 37.85^{\prime} \mathrm{N}, 83^{\circ} 11.41^{\prime} \mathrm{W}\right)$ & $\mathrm{C}$ & Str & 1 & Anido $^{u}$ & $1.38 \mathrm{~m}$ long \\
\hline
\end{tabular}

\begin{tabular}{|c|c|c|c|c|c|c|c|}
\hline \multicolumn{8}{|c|}{ ZIPHIIDAE } \\
\hline \multicolumn{8}{|c|}{ Unidentified beaked whale } \\
\hline Before 1955 & Caibarién & $\left(22^{\circ} 32.20^{\prime} \mathrm{N}, 79^{\circ} 26.96^{\prime} \mathrm{W}\right)$ & $\mathrm{C}$ & Str & 1 & Aguayo (1954) & $\begin{array}{l}\text { Skull is said to be in the Felipe } \\
\text { Poey Natural History Museum }\end{array}$ \\
\hline 28 Nov 1998 & $\begin{array}{l}\text { Off eastern coast of } \\
\text { Cuba }\end{array}$ & $20^{\circ} 22^{\prime} \mathrm{N}, 73^{\circ} 34^{\prime} \mathrm{W}$ & $\mathrm{C}$ & Cap & 1 & $\begin{array}{c}\text { NMFS-SEFSC } \\
(2004) \\
\end{array}$ & \\
\hline 12 Feb 2003 & $\begin{array}{l}\text { Off eastern coast of } \\
\text { Cuba }\end{array}$ & $20^{\circ} 16^{\prime} \mathrm{N}, 73^{\circ} 59^{\prime} \mathrm{W}$ & $\mathrm{C}$ & Cap & 1 & $\begin{array}{c}\text { Garrison and } \\
\text { Richards (2004); } \\
\text { NMFS-SEFSC } \\
(2004)\end{array}$ & \\
\hline \multicolumn{8}{|c|}{ Ziphius cavirostris } \\
\hline Before 1955 & Bahía de Matanzas & $\left(23^{\circ} 4.29^{\prime} \mathrm{N}, 81^{\circ} 29.45^{\prime} \mathrm{W}\right)$ & $\mathrm{P}$ & Str & 1 & Aguayo (1954) & $\begin{array}{l}\text { Skeleton said to be in the } \\
\text { Museum of Belén School }\end{array}$ \\
\hline Before 1955 & Caibarién & $\left(22^{\circ} 31^{\prime} \mathrm{N}, 79^{\circ} 26.96^{\prime} \mathrm{W}\right)$ & $\mathrm{P}$ & Str & 1 & Aguayo (1954) & $\begin{array}{l}\text { Skull said to be in the Felipe } \\
\text { Poey Natural History Museum }\end{array}$ \\
\hline 196- & $\begin{array}{l}\text { Off southern coast } \\
\text { of Isla de Pinos } \\
\text { (now Isla de la } \\
\text { Juventud) }\end{array}$ & $\left(21^{\circ} 27^{\prime} \mathrm{N}, 82^{\circ} 56^{\prime} \mathrm{W}\right)$ & $\mathrm{C}$ & Cap & 1 & $\begin{array}{l}\text { Varona }(1964) ; \\
\text { USNM }\end{array}$ & $\begin{array}{l}\text { Skull without mandibles received } \\
\text { from fisherman }\end{array}$ \\
\hline Jul 1970 & $\begin{array}{c}\text { Bahía de Cochinos, } \\
\text { Matanzas } \\
\end{array}$ & $\left(22^{\circ} 09.02^{\prime} \mathrm{N}, 81^{\circ} 09.22^{\prime} \mathrm{W}\right)$ & $\mathrm{C}$ & Str & 1 & Guitart $^{\mathrm{d}}$ & \\
\hline Oct 1971 & $\begin{array}{c}\text { Río Almendares, } \\
\text { Habana }\end{array}$ & $\left(23^{\circ} 9.07^{\prime} \mathrm{N}, 82^{\circ} 21.61^{\prime} \mathrm{W}\right)$ & $\mathrm{C}$ & Str & 1 & Varona (1980) & $5.5 \mathrm{~m}$ long \\
\hline Oct 1971 & Malecón, Habana & $\left(23^{\circ} 08.81^{\prime} \mathrm{N}, 82^{\circ} 23.27^{\prime} \mathrm{W}\right)$ & $\mathrm{C}$ & Str & 1 & Varona (1980) & $5 \mathrm{~m}$ long \\
\hline Oct 1971 & $\begin{array}{c}\text { Playa Boca Ciega, } \\
\text { Habana }\end{array}$ & $\left(23^{\circ} 01.33^{\prime} \mathrm{N}, 82^{\circ} 49.02^{\prime} \mathrm{W}\right)$ & $\mathrm{C}$ & Str & 3 & Varona (1980) & $5 \mathrm{~m}$ long \\
\hline Aug 1974 & $\begin{array}{l}\text { Playa Borracho, } \\
\text { Santiago de Cuba }\end{array}$ & $\left(19^{\circ} 53.10^{\prime} \mathrm{N}, 75^{\circ} 22.42^{\prime} \mathrm{W}\right)$ & $\mathrm{C}$ & Str & 1 & Soberat $^{\mathrm{n}}$ & \\
\hline
\end{tabular}




\begin{tabular}{|c|c|c|c|c|c|c|c|}
\hline Species/Date & Location & Position & Status $^{\mathrm{a}}$ & Type $^{\text {b }}$ & $\begin{array}{l}\text { Group } \\
\text { Size }\end{array}$ & Source $^{c}$ & Comments \\
\hline Jun 1979 & $\begin{array}{l}\text { Playa Siboney, } \\
\text { Santiago de Cuba }\end{array}$ & $\left(19^{\circ} 57.49^{\prime} \mathrm{N}, 75^{\circ} 42.71^{\prime} \mathrm{W}\right)$ & $\mathrm{C}$ & Str & 1 & Soberat $^{\mathrm{n}}$ & $5.15 \mathrm{~m}$ long \\
\hline Jun 1979 & $\begin{array}{c}\text { Playa Baracoa, } \\
\text { Guantánamo }\end{array}$ & $\left(20^{\circ} 21.04^{\prime} \mathrm{N}, 74^{\circ} 29.75^{\prime} \mathrm{W}\right)$ & $\mathrm{C}$ & Str & 1 & Soberat $^{\mathrm{n}}$ & $3.79 \mathrm{~m}$ long \\
\hline Mar 1986 & $\begin{array}{c}\text { Bahía de Nipe, } \\
\text { Holguín }\end{array}$ & $\left(20^{\circ} 44.78^{\prime} \mathrm{N}, 75^{\circ} 46.88^{\prime} \mathrm{W}\right)$ & $\mathrm{C}$ & Str & 14 & Guitart $^{\mathrm{d}}$ & $3.5-6 \mathrm{~m}$ long \\
\hline Oct 1988 & $\begin{array}{c}\text { Playa Siboney, } \\
\text { Santiago de Cuba }\end{array}$ & $\left(19^{\circ} 57.05^{\prime} \mathrm{N}, 75^{\circ} 42.74^{\prime} \mathrm{W}\right)$ & $\mathrm{C}$ & Str & 1 & $\begin{array}{c}\text { Blanco Domínguez } \\
(2011) \\
\end{array}$ & $3.79 \mathrm{~m}$ long \\
\hline 7 Jun 1991 & $\begin{array}{l}\text { Straits of Florida, } \\
\text { offshore of Habana }\end{array}$ & $23^{\circ} 46^{\prime} \mathrm{N}, 81^{\circ} 27^{\prime} \mathrm{W}$ & $\mathrm{C}$ & Sig & 4 & $\begin{array}{l}\text { Jefferson and Lynn } \\
(1994)\end{array}$ & \\
\hline Nov 1991 & $\begin{array}{c}\text { Playa } 1 \text { ra. and } 186, \\
\text { Habana }\end{array}$ & $\left(23^{\circ} 05.53^{\prime} \mathrm{N}, 82^{\circ} 28.86^{\prime} \mathrm{W}\right)$ & $\mathrm{C}$ & Str & 1 & $\begin{array}{l}\text { Blanco, M., pers. } \\
\text { obs. }\end{array}$ & $5 \mathrm{~m}$ long \\
\hline Mar 2003 & $\begin{array}{l}\text { Playa Cojímar, } \\
\text { Habana }\end{array}$ & $\left(23^{\circ} 10.24^{\prime} \mathrm{N}, 82^{\circ} 18.13^{\prime} \mathrm{W}\right)$ & $\mathrm{C}$ & Str & 1 & $\begin{array}{c}\text { López, N. and } \\
\text { Blanco, M., pers. } \\
\text { obs. }\end{array}$ & $4.45 \mathrm{~m}$ long \\
\hline Aug 2006 & $\begin{array}{c}\text { Playa El Cuero, } \\
\text { Santiago de Cuba }\end{array}$ & $\left(19^{\circ} 57.05^{\prime} \mathrm{N}, 76^{\circ} 00.99^{\prime} \mathrm{W}\right)$ & $\mathrm{C}$ & Str & 1 & Romero $^{\mathrm{v}}$ & \\
\hline May 2007 & $\begin{array}{c}\text { Playa Larga, } \\
\text { Santiago de Cuba }\end{array}$ & $\left(22^{\circ} 16.85^{\prime} \mathrm{N}, 81^{\circ} 12.37^{\prime} \mathrm{W}\right)$ & $\mathrm{C}$ & Str & 1 & Romerov $^{v}$ & \\
\hline \multicolumn{8}{|c|}{ Mesoplodon europaeus } \\
\hline Nov 1946 & $\begin{array}{l}\text { Cayo Alacranes, } \\
\text { Pinar del Río }\end{array}$ & $22^{\circ} 55^{\prime} \mathrm{N}, 83^{\circ} 26^{\prime} \mathrm{W}$ & $\mathrm{C}$ & Str & 1 & $\begin{array}{l}\text { Aguayo (1954); } \\
\text { Varona (1985) }\end{array}$ & $\begin{array}{l}\text { Cranium said to be in the Felipe } \\
\text { Poey Natural History Museum; } \\
\text { ca. } 425 \mathrm{~cm} \text { adult; Rankin (1956) } \\
\text { determined the specimen to be } \\
\text { an adult female }\end{array}$ \\
\hline Jul 1954 & Pinar del Río & N/A & $\mathrm{D}$ & Str & 1 & $\begin{array}{c}\text { Blanco Domínguez } \\
\text { (2011) }\end{array}$ & \\
\hline 6 Mar 1965 & $\begin{array}{l}\text { Arroyo Bermejo, } \\
\text { east of Habana }\end{array}$ & $23^{\circ} 9.22^{\prime} \mathrm{N}, 81^{\circ} 49.25^{\prime} \mathrm{W}$ & $\mathrm{C}$ & Str & 1 & $\begin{array}{c}\text { Varona (1970, } \\
1985)\end{array}$ & ca. $415 \mathrm{~cm}$ adult male \\
\hline 9 Nov 1969 & Bahía de Cabańas & $23^{\circ} 01^{\prime} \mathrm{N}, 82^{\circ} 57^{\prime} \mathrm{W}$ & $\mathrm{C}$ & Str & 1 & Varona (1985) & $454 \mathrm{~cm}$ female \\
\hline 23 Nov 1971 & Bahía Dominica & $23^{\circ} 01^{\prime} \mathrm{N}, 82^{\circ} 50^{\prime} \mathrm{W}$ & $\mathrm{C}$ & Str & 2 & Varona (1985) & $\begin{array}{c}\text { One adult female }(460 \mathrm{~cm}) \text { and } \\
\text { one immature male }(252 \mathrm{~cm})\end{array}$ \\
\hline Jun 1979 & $\begin{array}{c}\text { Playa Baracoa, } \\
\text { Guantánamo }\end{array}$ & $\left(20^{\circ} 20.86^{\prime} \mathrm{N}, 74^{\circ} 29.64^{\prime} \mathrm{W}\right)$ & $\mathrm{C}$ & Str & 1 & Soberat $^{\mathrm{n}}$ & $5.15 \mathrm{~m}$ long \\
\hline 4 Nov 1982 & $\begin{array}{l}\text { La Puntilla, near } \\
\text { Río Almendares }\end{array}$ & $23^{\circ} 08^{\prime} \mathrm{N}, 82^{\circ} 25^{\prime} \mathrm{W}$ & $\mathrm{C}$ & Str & 1 & Varona (1985) & $440 \mathrm{~cm}$ adult male \\
\hline Apr 1984 & $\begin{array}{c}\text { Bahía del Mariel, } \\
\text { Habana }\end{array}$ & $\left(23^{\circ} 01.46^{\prime} \mathrm{N}, 82^{\circ} 45.31^{\prime} \mathrm{W}\right)$ & $\mathrm{C}$ & Str & 1 & $\begin{array}{l}\text { Guitart, D. and } \\
\text { Blanco, M., pers. } \\
\text { obs. }\end{array}$ & $4.45 \mathrm{~m}$ long \\
\hline 5 Apr 1984 & $\begin{array}{c}\text { Santa Fe, } \\
\text { Barlovento, Habana }\end{array}$ & $23^{\circ} 06^{\prime} \mathrm{N}, 82^{\circ} 30^{\prime} \mathrm{W}$ & $\mathrm{C}$ & Str & 1 & Varona (1985) & $485 \mathrm{~cm}$ adult female \\
\hline 5 Apr 1984 & $\begin{array}{c}\text { Playita de 16, } \\
\text { Miramar, Habana }\end{array}$ & $23^{\circ} 08^{\prime} \mathrm{N}, 82^{\circ} 25^{\prime} \mathrm{W}$ & $\mathrm{C}$ & Str & 1 & Varona (1985) & $250 \mathrm{~cm}$ immature male \\
\hline Aug 1988 & $\begin{array}{l}\text { Playa Baracoa, } \\
\text { Habana }\end{array}$ & $\left(23^{\circ} 03.03^{\prime} \mathrm{N}, 82^{\circ} 34.65^{\prime} \mathrm{W}\right)$ & $\mathrm{C}$ & Str & 1 & $\begin{array}{c}\text { Guitart, D. and } \\
\text { Blanco, M., pers. } \\
\text { obs. }\end{array}$ & $5 \mathrm{~m}$ long \\
\hline Oct 1988 & $\begin{array}{c}\text { Playa Siboney, } \\
\text { Santiago de Cuba }\end{array}$ & $\left(19^{\circ} 57.55^{\prime} \mathrm{N}, 75^{\circ} 42.15^{\prime} \mathrm{W}\right)$ & $\mathrm{C}$ & Str & 1 & Soberat $^{\mathrm{n}}$ & $3.79 \mathrm{~m}$ long \\
\hline
\end{tabular}




\begin{tabular}{|c|c|c|c|c|c|c|c|}
\hline Species/Date & Location & Position & Status $^{\mathrm{a}}$ & Type $^{\text {b }}$ & $\begin{array}{l}\text { Group } \\
\text { Size }\end{array}$ & Source $^{c}$ & Comments \\
\hline \multicolumn{8}{|c|}{ DELPHINIDAE } \\
\hline \multicolumn{8}{|c|}{ Steno bredanensis } \\
\hline N/A & Near Habana & $\left(23^{\circ} 10.34^{\prime} \mathrm{N}, 82^{\circ} 22.73^{\prime} \mathrm{W}\right)$ & $\mathrm{P}$ & Cap & 1 & Aguayo (1954) & $\begin{array}{l}\text { Skull is said to be in the Poey } \\
\text { Museum }\end{array}$ \\
\hline Nov 2001 & $\begin{array}{l}\text { Playa Chivirico, } \\
\text { Santiago de Cuba }\end{array}$ & $\left(19^{\circ} 58.18^{\prime} \mathrm{N}, 76^{\circ} 24.55^{\prime} \mathrm{W}\right)$ & $\mathrm{C}$ & Str & 1 & Soberat $^{\mathrm{n}}$ & $2.21 \mathrm{~m}$ long \\
\hline May 2004 & $\begin{array}{l}\text { Santa Cruz del } \\
\text { Norte, Habana }\end{array}$ & $\left(23^{\circ} 09.52^{\prime} \mathrm{N}, 81^{\circ} 55.05^{\prime} \mathrm{W}\right)$ & $\mathrm{C}$ & Str & 1 & $\begin{array}{c}\text { Guevara, C. and } \\
\text { Blanco, M., pers. obs. }\end{array}$ & $1.63 \mathrm{~m}$ long \\
\hline 17 Sept 2005 & $\begin{array}{c}\text { Off Cayo Coco } \\
\text { and Cayo Fragoso, } \\
\text { northern coast of } \\
\text { Cuba }\end{array}$ & $22^{\circ} 37.08^{\prime} \mathrm{N}, 78^{\circ} 42.54^{\prime} \mathrm{W}$ & $\mathrm{C}$ & Det & 1 & Wells et al. (2008) & Tagged individual \#42480 \\
\hline 17 Sept 2005 & $\begin{array}{c}\text { Off Cayo Coco } \\
\text { and Cayo Fragoso, } \\
\text { northern coast of } \\
\text { Cuba }\end{array}$ & $22^{\circ} 38.28^{\prime} \mathrm{N}, 78^{\circ} 45.36^{\prime} \mathrm{W}$ & $\mathrm{C}$ & Det & 1 & Wells et al. (2008) & Tagged individual \#42481 \\
\hline 17 Sept 2005 & $\begin{array}{c}\text { Off Cayo Coco } \\
\text { and Cayo Fragoso, } \\
\text { northern coast of } \\
\text { Cuba }\end{array}$ & $22^{\circ} 38.04^{\prime} \mathrm{N}, 78^{\circ} 44.70^{\prime} \mathrm{W}$ & $\mathrm{C}$ & Det & 1 & Wells et al. (2008) & Tagged individual \#42481 \\
\hline 17 Sept 2005 & $\begin{array}{c}\text { Off Cayo Coco } \\
\text { and Cayo Fragoso, } \\
\text { northern coast of } \\
\text { Cuba }\end{array}$ & $22^{\circ} 36.24^{\prime} \mathrm{N}, 78^{\circ} 40.68^{\prime} \mathrm{W}$ & $\mathrm{C}$ & Det & 1 & Wells et al. (2008) & Tagged individual \#42481 \\
\hline 17 Sept 2005 & $\begin{array}{c}\text { Off Cayo Coco } \\
\text { and Cayo Fragoso, } \\
\text { northern coast of } \\
\text { Cuba }\end{array}$ & $22^{\circ} 40.86^{\prime} \mathrm{N}, 79^{\circ} 18.00^{\prime} \mathrm{W}$ & $\mathrm{C}$ & Det & 1 & Wells et al. (2008) & Tagged individual \#42481 \\
\hline 18 Sept 2005 & $\begin{array}{c}\text { Off Cayo Coco } \\
\text { and Cayo Fragoso, } \\
\text { northern coast of } \\
\text { Cuba }\end{array}$ & $22^{\circ} 45.30^{\prime} \mathrm{N}, 78^{\circ} 51.78^{\prime} \mathrm{W}$ & $\mathrm{C}$ & Det & 1 & Wells et al. (2008) & Tagged individual \#42480 \\
\hline 18 Sept 2005 & $\begin{array}{c}\text { Off Cayo Coco } \\
\text { and Cayo Fragoso, } \\
\text { northern coast of } \\
\text { Cuba }\end{array}$ & $22^{\circ} 36.90^{\prime} \mathrm{N}, 78^{\circ} 33.24^{\prime} \mathrm{W}$ & $\mathrm{C}$ & Det & 1 & Wells et al. (2008) & Tagged individual \#42480 \\
\hline 18 Sept 2005 & $\begin{array}{c}\text { Off Cayo Coco } \\
\text { and Cayo Fragoso, } \\
\text { northern coast of } \\
\text { Cuba }\end{array}$ & $22^{\circ} 36.12^{\prime} \mathrm{N}, 78^{\circ} 38.10^{\prime} \mathrm{W}$ & $\mathrm{C}$ & Det & 1 & Wells et al. (2008) & Tagged individual \#42480 \\
\hline 18 Sept 2005 & $\begin{array}{c}\text { Off Cayo Coco } \\
\text { and Cayo Fragoso, } \\
\text { northern coast of } \\
\text { Cuba }\end{array}$ & $22^{\circ} 36.54^{\prime} \mathrm{N}, 78^{\circ} 37.44^{\prime} \mathrm{W}$ & $\mathrm{C}$ & Det & 1 & Wells et al. (2008) & Tagged individual \#42481 \\
\hline 18 Sept 2005 & $\begin{array}{c}\text { Off Cayo Coco } \\
\text { and Cayo Fragoso, } \\
\text { northern coast of } \\
\text { Cuba }\end{array}$ & $22^{\circ} 37.86^{\prime} \mathrm{N}, 78^{\circ} 37.44^{\prime} \mathrm{W}$ & $\mathrm{C}$ & Det & 1 & Wells et al. (2008) & Tagged individual \#42481 \\
\hline 19 Sept 2005 & $\begin{array}{c}\text { Off Cayo Coco } \\
\text { and Cayo Fragoso, } \\
\text { northern coast of } \\
\text { Cuba }\end{array}$ & $22^{\circ} 34.32^{\prime} \mathrm{N}, 78^{\circ} 23.34^{\prime} \mathrm{W}$ & $\mathrm{C}$ & Det & 1 & Wells et al. (2008) & Tagged individual \#42480 \\
\hline 19 Sept 2005 & $\begin{array}{c}\text { Off Cayo Coco } \\
\text { and Cayo Fragoso, } \\
\text { northern coast of } \\
\text { Cuba }\end{array}$ & $22^{\circ} 33.78^{\prime} \mathrm{N}, 78^{\circ} 19.92^{\prime} \mathrm{W}$ & $\mathrm{C}$ & Det & 1 & Wells et al. (2008) & Tagged individual \#42480 \\
\hline 19 Sept 2005 & $\begin{array}{c}\text { Off Cayo Coco } \\
\text { and Cayo Fragoso, } \\
\text { northern coast of } \\
\text { Cuba }\end{array}$ & $22^{\circ} 34.02^{\prime} \mathrm{N}, 78^{\circ} 18.24^{\prime} \mathrm{W}$ & $\mathrm{C}$ & Det & 1 & Wells et al. (2008) & Tagged individual \#42480 \\
\hline 19 Sept 2005 & $\begin{array}{c}\text { Off Cayo Coco } \\
\text { and Cayo Fragoso, } \\
\text { northern coast of } \\
\text { Cuba }\end{array}$ & $22^{\circ} 27.48^{\prime} \mathrm{N}, 78^{\circ} 16.80^{\prime} \mathrm{W}$ & $\mathrm{C}$ & Det & 1 & Wells et al. (2008) & Tagged individual \#42481 \\
\hline 19 Sept 2005 & $\begin{array}{c}\text { Off Cayo Coco } \\
\text { and Cayo Fragoso, } \\
\text { northern coast of } \\
\text { Cuba }\end{array}$ & $22^{\circ} 32.28^{\prime} \mathrm{N}, 78^{\circ} 7.32^{\prime} \mathrm{W}$ & $\mathrm{C}$ & Det & 1 & Wells et al. (2008) & Tagged individual \#42481 \\
\hline
\end{tabular}




\begin{tabular}{|c|c|c|c|c|c|c|c|}
\hline Species/Date & Location & Position & Status $^{a}$ & Type $^{\mathrm{b}}$ & $\begin{array}{l}\text { Group } \\
\text { Size }\end{array}$ & Source $^{c}$ & Comments \\
\hline 21 Sept 2005 & $\begin{array}{c}\text { Off Cayo Coco } \\
\text { and Cayo Fragoso, } \\
\text { northern coast of } \\
\text { Cuba }\end{array}$ & $22^{\circ} 46.86^{\prime} \mathrm{N}, 78^{\circ} 36.66^{\prime} \mathrm{W}$ & $\mathrm{C}$ & Det & 1 & Wells et al. (2008) & Tagged individual \#42481 \\
\hline 22 Sept 2005 & $\begin{array}{c}\text { Off Cayo Coco } \\
\text { and Cayo Fragoso, } \\
\text { northern coast of } \\
\text { Cuba }\end{array}$ & $22^{\circ} 34.98^{\prime} \mathrm{N}, 78^{\circ} 26.64^{\prime} \mathrm{W}$ & $\mathrm{C}$ & Det & 1 & Wells et al. (2008) & Tagged individual \#42480 \\
\hline 22 Sept 2005 & $\begin{array}{c}\text { Off Cayo Coco } \\
\text { and Cayo Fragoso, } \\
\text { northern coast of } \\
\text { Cuba }\end{array}$ & $22^{\circ} 34.98^{\prime} \mathrm{N}, 78^{\circ} 25.56^{\prime} \mathrm{W}$ & $\mathrm{C}$ & Det & 1 & Wells et al. (2008) & Tagged individual \#42480 \\
\hline 22 Sept 2005 & $\begin{array}{c}\text { Off Cayo Coco } \\
\text { and Cayo Fragoso, } \\
\text { northern coast of } \\
\text { Cuba }\end{array}$ & $22^{\circ} 34.74^{\prime} \mathrm{N}, 78^{\circ} 24.36^{\prime} \mathrm{W}$ & $\mathrm{C}$ & Det & 1 & Wells et al. (2008) & Tagged individual \#42480 \\
\hline 22 Sept 2005 & $\begin{array}{c}\text { Off Cayo Coco } \\
\text { and Cayo Fragoso, } \\
\text { northern coast of } \\
\text { Cuba }\end{array}$ & $22^{\circ} 35.88^{\prime} \mathrm{N}, 78^{\circ} 27.84^{\prime} \mathrm{W}$ & $\mathrm{C}$ & Det & 1 & Wells et al. (2008) & Tagged individual \#42480 \\
\hline 22 Sept 2005 & $\begin{array}{c}\text { Off Cayo Coco } \\
\text { and Cayo Fragoso, } \\
\text { northern coast of } \\
\text { Cuba }\end{array}$ & $22^{\circ} 35.10^{\prime} \mathrm{N}, 78^{\circ} 26.46^{\prime} \mathrm{W}$ & $\mathrm{C}$ & Det & 1 & Wells et al. (2008) & Tagged individual \#42481 \\
\hline 22 Sept 2005 & $\begin{array}{c}\text { Off Cayo Coco } \\
\text { and Cayo Fragoso, } \\
\text { northern coast of } \\
\text { Cuba }\end{array}$ & $22^{\circ} 40.38^{\prime} \mathrm{N}, 78^{\circ} 22.68^{\prime} \mathrm{W}$ & $\mathrm{C}$ & Det & 1 & Wells et al. (2008) & Tagged individual \#42481 \\
\hline 22 Sept 2005 & $\begin{array}{c}\text { Off Cayo Coco } \\
\text { and Cayo Fragoso, } \\
\text { northern coast of } \\
\text { Cuba }\end{array}$ & $22^{\circ} 34.38^{\prime} \mathrm{N}, 78^{\circ} 25.68^{\prime} \mathrm{W}$ & $\mathrm{C}$ & Det & 1 & Wells et al. (2008) & Tagged individual \#42481 \\
\hline 22 Sept 2005 & $\begin{array}{c}\text { Off Cayo Coco } \\
\text { and Cayo Fragoso, } \\
\text { northern coast of } \\
\text { Cuba }\end{array}$ & $22^{\circ} 36.48^{\prime} \mathrm{N}, 78^{\circ} 27.78^{\prime} \mathrm{W}$ & $\mathrm{C}$ & Det & 1 & Wells et al. (2008) & Tagged individual \#42481 \\
\hline 23 Sept 2005 & $\begin{array}{c}\text { Off Cayo Coco } \\
\text { and Cayo Fragoso, } \\
\text { northern coast of } \\
\text { Cuba }\end{array}$ & $22^{\circ} 46.02^{\prime} \mathrm{N}, 78^{\circ} 58.92^{\prime} \mathrm{W}$ & $\mathrm{C}$ & Det & 1 & Wells et al. (2008) & Tagged individual \#42480 \\
\hline 23 Sept 2005 & $\begin{array}{c}\text { Off Cayo Coco } \\
\text { and Cayo Fragoso, } \\
\text { northern coast of } \\
\text { Cuba }\end{array}$ & $22^{\circ} 44.70^{\prime} \mathrm{N}, 78^{\circ} 58.62^{\prime} \mathrm{W}$ & $\mathrm{C}$ & Det & 1 & Wells et al. (2008) & Tagged individual \#42480 \\
\hline 23 Sept 2005 & $\begin{array}{c}\text { Off Cayo Coco } \\
\text { and Cayo Fragoso, } \\
\text { northern coast of } \\
\text { Cuba }\end{array}$ & $22^{\circ} 43.56^{\prime} \mathrm{N}, 78^{\circ} 58.32^{\prime} \mathrm{W}$ & $\mathrm{C}$ & Det & 1 & Wells et al. (2008) & Tagged individual \#42480 \\
\hline 23 Sept 2005 & $\begin{array}{c}\text { Off Cayo Coco } \\
\text { and Cayo Fragoso, } \\
\text { northern coast of } \\
\text { Cuba }\end{array}$ & $22^{\circ} 45.24^{\prime} \mathrm{N}, 78^{\circ} 59.16^{\prime} \mathrm{W}$ & $\mathrm{C}$ & Det & 1 & Wells et al. (2008) & Tagged individual \#42481 \\
\hline 23 Sept 2005 & $\begin{array}{c}\text { Off Cayo Coco } \\
\text { and Cayo Fragoso, } \\
\text { northern coast of } \\
\text { Cuba }\end{array}$ & $22^{\circ} 45.30^{\prime} \mathrm{N}, 78^{\circ} 58.08^{\prime} \mathrm{W}$ & $\mathrm{C}$ & Det & 1 & Wells et al. (2008) & Tagged individual \#42481 \\
\hline 23 Sept 2005 & $\begin{array}{c}\text { Off Cayo Coco } \\
\text { and Cayo Fragoso, } \\
\text { northern coast of } \\
\text { Cuba }\end{array}$ & $22^{\circ} 43.86^{\prime} \mathrm{N}, 78^{\circ} 59.88^{\prime} \mathrm{W}$ & $\mathrm{C}$ & Det & 1 & Wells et al. (2008) & Tagged individual \#42481 \\
\hline 23 Sept 2005 & $\begin{array}{c}\text { Off Cayo Coco } \\
\text { and Cayo Fragoso, } \\
\text { northern coast of } \\
\text { Cuba }\end{array}$ & $22^{\circ} 46.20^{\prime} \mathrm{N}, 78^{\circ} 55.20^{\prime} \mathrm{W}$ & $\mathrm{C}$ & Det & 1 & Wells et al. (2008) & Tagged individual \#42481 \\
\hline 24 Sept 2005 & $\begin{array}{c}\text { Off Cayo Coco } \\
\text { and Cayo Fragoso, } \\
\text { northern coast of } \\
\text { Cuba }\end{array}$ & $22^{\circ} 44.64{ }^{\prime} \mathrm{N}, 78^{\circ} 57.96^{\prime} \mathrm{W}$ & $\mathrm{C}$ & Det & 1 & Wells et al. (2008) & Tagged individual \#42481 \\
\hline
\end{tabular}




\begin{tabular}{|c|c|c|c|c|c|c|c|}
\hline Species/Date & Location & Position & Status $^{\mathrm{a}}$ & Type & $\begin{array}{l}\text { Group } \\
\text { Size }\end{array}$ & Source $^{c}$ & Comments \\
\hline 24 Sept 2005 & $\begin{array}{c}\text { Off Cayo Coco } \\
\text { and Cayo Fragoso, } \\
\text { northern coast of } \\
\text { Cuba }\end{array}$ & $22^{\circ} 44.76^{\prime} \mathrm{N}, 78^{\circ} 58.56^{\prime} \mathrm{W}$ & $\mathrm{C}$ & Det & 1 & Wells et al. (2008) & Tagged individual \#42481 \\
\hline 24 Sept 2005 & $\begin{array}{c}\text { Off Cayo Coco } \\
\text { and Cayo Fragoso, } \\
\text { northern coast of } \\
\text { Cuba }\end{array}$ & $22^{\circ} 45.60^{\prime} \mathrm{N}, 78^{\circ} 54.78^{\prime} \mathrm{W}$ & $\mathrm{C}$ & Det & 1 & Wells et al. (2008) & Tagged individual \#42481 \\
\hline 24 Sept 2005 & $\begin{array}{c}\text { Off Cayo Coco } \\
\text { and Cayo Fragoso, } \\
\text { northern coast of } \\
\text { Cuba }\end{array}$ & $22^{\circ} 43.80^{\prime} \mathrm{N}, 79^{\circ} 21.00^{\prime} \mathrm{W}$ & $\mathrm{C}$ & Det & 1 & Wells et al. (2008) & Tagged individual \#42481 \\
\hline 25 Sept 2005 & $\begin{array}{c}\text { Off Cayo Coco } \\
\text { and Cayo Fragoso, } \\
\text { northern coast of } \\
\text { Cuba }\end{array}$ & $22^{\circ} 45.06^{\prime} \mathrm{N}, 79^{\circ} 23.04^{\prime} \mathrm{W}$ & $\mathrm{C}$ & Det & 1 & Wells et al. (2008) & Tagged individual \#42481 \\
\hline \multicolumn{8}{|c|}{ Tursiops truncatus } \\
\hline 10 Dec 1983 & Off Varadero & $23^{\circ} 04^{\prime} \mathrm{N}, 81^{\circ} 09^{\prime} \mathrm{W}$ & $\mathrm{C}$ & Sig & 2 & $\begin{array}{c}\text { Blanco and } \\
\text { Olaechea (1996) }\end{array}$ & $\begin{array}{c}\text { Individuals were captured, } \\
\text { measured, and released }\end{array}$ \\
\hline 11 Dec 1983 & Off Varadero & $23^{\circ} 11^{\prime} \mathrm{N}, 81^{\circ} 04^{\prime} \mathrm{W}$ & $\mathrm{C}$ & Sig & 2 & $\begin{array}{c}\text { Blanco and } \\
\text { Olaechea (1996) }\end{array}$ & $\begin{array}{c}\text { Individuals were captured, } \\
\text { measured, and released }\end{array}$ \\
\hline 12 Dec 1983 & Off Varadero & $23^{\circ} 10^{\prime} \mathrm{N}, 81^{\circ} 07^{\prime} \mathrm{W}$ & $\mathrm{C}$ & Sig & 4 & $\begin{array}{c}\text { Blanco and } \\
\text { Olaechea (1996) }\end{array}$ & $\begin{array}{c}\text { Individuals were captured, } \\
\text { measured, and released }\end{array}$ \\
\hline 13 Dec 1983 & Off Varadero & $23^{\circ} 11^{\prime} \mathrm{N}, 81^{\circ} 03^{\prime} \mathrm{W}$ & $\mathrm{C}$ & Sig & 1 & $\begin{array}{c}\text { Blanco and } \\
\text { Olaechea (1996) }\end{array}$ & $\begin{array}{c}\text { Individuals were captured, } \\
\text { measured, and released }\end{array}$ \\
\hline 15 Dec 1983 & Off Varadero & $23^{\circ} 03^{\prime} \mathrm{N}, 81^{\circ} 09^{\prime} \mathrm{W}$ & $\mathrm{C}$ & Sig & 3 & $\begin{array}{c}\text { Blanco and } \\
\text { Olaechea (1996) }\end{array}$ & $\begin{array}{c}\text { Individuals were captured, } \\
\text { measured, and released }\end{array}$ \\
\hline 20 Dec 1983 & Off Varadero & $23^{\circ} 11^{\prime} \mathrm{N}, 81^{\circ} 06^{\prime} \mathrm{W}$ & $\mathrm{C}$ & Sig & 2 & $\begin{array}{c}\text { Blanco and } \\
\text { Olaechea (1996) }\end{array}$ & $\begin{array}{c}\text { Individuals were captured, } \\
\text { measured, and released }\end{array}$ \\
\hline 22 Dec 1983 & Off Varadero & $23^{\circ} 11^{\prime} \mathrm{N}, 81^{\circ} 06^{\prime} \mathrm{W}$ & $\mathrm{C}$ & Sig & 5 & $\begin{array}{c}\text { Blanco and } \\
\text { Olaechea (1996) }\end{array}$ & $\begin{array}{c}\text { Individuals were captured, } \\
\text { measured, and released }\end{array}$ \\
\hline 8 Mar 1984 & Off Varadero & $23^{\circ} 11^{\prime} \mathrm{N}, 81^{\circ} 04^{\prime} \mathrm{W}$ & $\mathrm{C}$ & Sig & 4 & $\begin{array}{c}\text { Blanco and } \\
\text { Olaechea (1996) }\end{array}$ & $\begin{array}{c}\text { Individuals were captured, } \\
\text { measured, and released }\end{array}$ \\
\hline 12 Jun 1984 & Off Varadero & $23^{\circ} 11^{\prime} \mathrm{N}, 81^{\circ} 06^{\prime} \mathrm{W}$ & $\mathrm{C}$ & Sig & 1 & $\begin{array}{c}\text { Blanco and } \\
\text { Olaechea (1996) }\end{array}$ & $\begin{array}{c}\text { Individuals were captured, } \\
\text { measured, and released }\end{array}$ \\
\hline 5 Mar 1985 & Off Varadero & $23^{\circ} 11^{\prime} \mathrm{N}, 81^{\circ} 07^{\prime} \mathrm{W}$ & $\mathrm{C}$ & Sig & 5 & $\begin{array}{c}\text { Blanco and } \\
\text { Olaechea (1996) }\end{array}$ & $\begin{array}{c}\text { Individuals were captured, } \\
\text { measured, and released }\end{array}$ \\
\hline 25 Apr 1985 & Off Varadero & $23^{\circ} 11^{\prime} \mathrm{N}, 81^{\circ} 06^{\prime} \mathrm{W}$ & $\mathrm{C}$ & Sig & 4 & $\begin{array}{c}\text { Blanco and } \\
\text { Olaechea (1996) }\end{array}$ & $\begin{array}{c}\text { Individuals were captured, } \\
\text { measured, and released }\end{array}$ \\
\hline $11 \mathrm{Jul} 1985$ & Off Varadero & $23^{\circ} 12^{\prime} \mathrm{N}, 81^{\circ} 07^{\prime} \mathrm{W}$ & $\mathrm{C}$ & Sig & 1 & $\begin{array}{c}\text { Blanco and } \\
\text { Olaechea (1996) }\end{array}$ & $\begin{array}{c}\text { Individuals were captured, } \\
\text { measured, and released }\end{array}$ \\
\hline $11 \mathrm{Jul} 1985$ & Off Varadero & $23^{\circ} 13^{\prime} \mathrm{N}, 81^{\circ} 02^{\prime} \mathrm{W}$ & $\mathrm{C}$ & Sig & 3 & $\begin{array}{c}\text { Blanco and } \\
\text { Olaechea (1996) }\end{array}$ & $\begin{array}{c}\text { Individuals were captured, } \\
\text { measured, and released }\end{array}$ \\
\hline $14 \mathrm{Jul} 1985$ & Off Varadero & $23^{\circ} 11^{\prime} \mathrm{N}, 81^{\circ} 07^{\prime} \mathrm{W}$ & $\mathrm{C}$ & Sig & 2 & $\begin{array}{c}\text { Blanco and } \\
\text { Olaechea (1996) }\end{array}$ & $\begin{array}{c}\text { Individuals were captured, } \\
\text { measured, and released }\end{array}$ \\
\hline 16 Jul 1985 & Off Varadero & $23^{\circ} 14^{\prime} \mathrm{N}, 81^{\circ} 01^{\prime} \mathrm{W}$ & $\mathrm{C}$ & Sig & 6 & $\begin{array}{c}\text { Blanco and } \\
\text { Olaechea (1996) }\end{array}$ & $\begin{array}{c}\text { Individuals were captured, } \\
\text { measured, and released }\end{array}$ \\
\hline 26 Mar 1986 & Off Varadero & $23^{\circ} 12^{\prime} \mathrm{N}, 81^{\circ} 07^{\prime} \mathrm{W}$ & $\mathrm{C}$ & Sig & 3 & $\begin{array}{c}\text { Blanco and } \\
\text { Olaechea (1996) }\end{array}$ & $\begin{array}{c}\text { Individuals were captured, } \\
\text { measured, and released }\end{array}$ \\
\hline 8 Apr 1986 & Off Varadero & $23^{\circ} 11^{\prime} \mathrm{N}, 81^{\circ} 11^{\prime} \mathrm{W}$ & $\mathrm{C}$ & Sig & 3 & $\begin{array}{c}\text { Blanco and } \\
\text { Olaechea (1996) }\end{array}$ & $\begin{array}{c}\text { Individuals were captured, } \\
\text { measured, and released }\end{array}$ \\
\hline 22 Apr 1986 & Off Varadero & $23^{\circ} 15^{\prime} \mathrm{N}, 81^{\circ} 01^{\prime} \mathrm{W}$ & $\mathrm{C}$ & Sig & 6 & $\begin{array}{c}\text { Blanco and } \\
\text { Olaechea (1996) }\end{array}$ & $\begin{array}{c}\text { Individuals were captured, } \\
\text { measured, and released }\end{array}$ \\
\hline 2 May 1986 & Off Varadero & $23^{\circ} 13^{\prime} \mathrm{N}, 81^{\circ} 02^{\prime} \mathrm{W}$ & $\mathrm{C}$ & Sig & 5 & $\begin{array}{c}\text { Blanco and } \\
\text { Olaechea (1996) }\end{array}$ & $\begin{array}{c}\text { Individuals were captured, } \\
\text { measured, and released }\end{array}$ \\
\hline 14 Dec 1994 & Off Varadero & $23^{\circ} 16^{\prime} \mathrm{N}, 81^{\circ} 05^{\prime} \mathrm{W}$ & $\mathrm{C}$ & Sig & 5 & $\begin{array}{c}\text { Blanco and } \\
\text { Olaechea (1996) }\end{array}$ & $\begin{array}{c}\text { Individuals were captured, } \\
\text { measured, and released }\end{array}$ \\
\hline 18 Dec 1994 & Off Varadero & $23^{\circ} 16^{\prime} \mathrm{N}, 81^{\circ} 07^{\prime} \mathrm{W}$ & $\mathrm{C}$ & Sig & 5 & $\begin{array}{c}\text { Blanco and } \\
\text { Olaechea (1996) }\end{array}$ & $\begin{array}{c}\text { Individuals were captured, } \\
\text { measured, and released }\end{array}$ \\
\hline 1 Mar 1995 & Off Varadero & $23^{\circ} 11^{\prime} \mathrm{N}, 81^{\circ} 04^{\prime} \mathrm{W}$ & $\mathrm{C}$ & Sig & 2 & $\begin{array}{c}\text { Blanco and } \\
\text { Olaechea (1996) }\end{array}$ & $\begin{array}{c}\text { Individuals were captured, } \\
\text { measured, and released }\end{array}$ \\
\hline 24 Mar 1995 & Off Varadero & $23^{\circ} 14^{\prime} \mathrm{N}, 80^{\circ} 58^{\prime} \mathrm{W}$ & $\mathrm{C}$ & Sig & 5 & $\begin{array}{c}\text { Blanco and } \\
\text { Olaechea (1996) }\end{array}$ & $\begin{array}{c}\text { Individuals were captured, } \\
\text { measured, and released }\end{array}$ \\
\hline 24 Mar 1995 & Off Varadero & $23^{\circ} 11^{\prime} \mathrm{N}, 81^{\circ} 07^{\prime} \mathrm{W}$ & $\mathrm{C}$ & Sig & 2 & $\begin{array}{c}\text { Blanco and } \\
\text { Olaechea (1996) }\end{array}$ & $\begin{array}{c}\text { Individuals were captured, } \\
\text { measured, and released }\end{array}$ \\
\hline 27 Mar 1995 & Off Varadero & $23^{\circ} 11^{\prime} \mathrm{N}, 81^{\circ} 00^{\prime} \mathrm{W}$ & $\mathrm{C}$ & Sig & 3 & $\begin{array}{c}\text { Blanco and } \\
\text { Olaechea (1996) }\end{array}$ & $\begin{array}{c}\text { Individuals were captured, } \\
\text { measured, and released }\end{array}$ \\
\hline
\end{tabular}




\begin{tabular}{|c|c|c|c|c|c|c|c|}
\hline Species/Date & Location & Position & Status $^{\mathrm{a}}$ & Type $^{\text {b }}$ & $\begin{array}{l}\text { Group } \\
\text { Size }\end{array}$ & Source $^{c}$ & Comments \\
\hline 20 Apr 1995 & Off Varadero & $23^{\circ} 12^{\prime} \mathrm{N}, 81^{\circ} 08^{\prime} \mathrm{W}$ & $\mathrm{C}$ & Sig & 4 & $\begin{array}{c}\text { Blanco and } \\
\text { Olaechea (1996) }\end{array}$ & $\begin{array}{c}\text { Individuals were captured, } \\
\text { measured, and released }\end{array}$ \\
\hline 20 Apr 1995 & Off Varadero & $23^{\circ} 13^{\prime} \mathrm{N}, 81^{\circ} 02^{\prime} \mathrm{W}$ & $\mathrm{C}$ & Sig & 3 & $\begin{array}{c}\text { Blanco and } \\
\text { Olaechea (1996) }\end{array}$ & $\begin{array}{c}\text { Individuals were captured, } \\
\text { measured, and released }\end{array}$ \\
\hline 24 May 1995 & Off Varadero & $23^{\circ} 11^{\prime} \mathrm{N}, 81^{\circ} 03^{\prime} \mathrm{W}$ & $\mathrm{C}$ & Sig & 2 & $\begin{array}{c}\text { Blanco and } \\
\text { Olaechea (1996) }\end{array}$ & $\begin{array}{c}\text { Individuals were captured, } \\
\text { measured, and released }\end{array}$ \\
\hline 6 Sept 1995 & Off Varadero & $23^{\circ} 15^{\prime} \mathrm{N}, 81^{\circ} 07^{\prime} \mathrm{W}$ & $\mathrm{C}$ & Sig & 3 & $\begin{array}{c}\text { Blanco and } \\
\text { Olaechea (1996) }\end{array}$ & $\begin{array}{c}\text { Individuals were captured, } \\
\text { measured, and released }\end{array}$ \\
\hline 18 Dec 1995 & Off Varadero & $23^{\circ} 11^{\prime} \mathrm{N}, 81^{\circ} 07^{\prime} \mathrm{W}$ & $\mathrm{C}$ & Sig & 4 & $\begin{array}{c}\text { Blanco and } \\
\text { Olaechea (1996) }\end{array}$ & $\begin{array}{c}\text { Individuals were captured, } \\
\text { measured, and released }\end{array}$ \\
\hline 29 Sept 1999 & $\begin{array}{c}\text { Off Caracoles } \\
\text { Point, GTMO }\end{array}$ & $\left(19^{\circ} 54^{\prime} \mathrm{N}, 75^{\circ} 12^{\prime} \mathrm{W}\right)$ & $\mathrm{C}$ & Sig & $>5$ & $\begin{array}{l}\text { GTMO unpub. } \\
\text { data }\end{array}$ & \\
\hline Feb-Dec 2000 & $\begin{array}{c}\text { Costa Norte, Cayo } \\
\text { Coco } \\
\end{array}$ & $\left(22^{\circ} 36.56^{\prime} \mathrm{N}, 78^{\circ} 42.29^{\prime} \mathrm{W}\right)$ & $\mathrm{C}$ & Sig & N/A & Pérez-Cao $(2004)^{w}$ & \\
\hline Feb-Dec 2000 & $\begin{array}{c}\text { Costa Norte, Cayo } \\
\text { Coco }\end{array}$ & $\left(22^{\circ} 36.97^{\prime} \mathrm{N}, 78^{\circ} 42.12^{\prime} \mathrm{W}\right)$ & $\mathrm{C}$ & Sig & N/A & Pérez-Cao (2004) & \\
\hline Feb-Dec 2000 & $\begin{array}{c}\text { Costa Norte, Cayo } \\
\text { Coco } \\
\end{array}$ & $\left(22^{\circ} 36.97^{\prime} \mathrm{N}, 78^{\circ} 40.70^{\prime} \mathrm{W}\right)$ & $\mathrm{C}$ & Sig & N/A & Pérez-Cao (2004) & \\
\hline Feb-Dec 2000 & $\begin{array}{c}\text { Costa Norte, Cayo } \\
\text { Coco }\end{array}$ & $\left(22^{\circ} 36.27^{\prime} \mathrm{N}, 78^{\circ} 39.60^{\prime} \mathrm{W}\right)$ & $\mathrm{C}$ & Sig & N/A & Pérez-Cao (2004) & \\
\hline Feb-Dec 2000 & $\begin{array}{c}\text { Costa Norte, Cayo } \\
\text { Coco }\end{array}$ & $\left(22^{\circ} 35.72^{\prime} \mathrm{N}, 78^{\circ} 37.57^{\prime} \mathrm{W}\right)$ & $\mathrm{C}$ & Sig & N/A & Pérez-Cao (2004) & \\
\hline Feb-Dec 2000 & $\begin{array}{c}\text { Costa Norte, Cayo } \\
\text { Coco } \\
\end{array}$ & $\left(22^{\circ} 35.72^{\prime} \mathrm{N}, 78^{\circ} 36.77^{\prime} \mathrm{W}\right)$ & $\mathrm{C}$ & Sig & N/A & Pérez-Cao (2004) & \\
\hline Feb-Dec 2000 & $\begin{array}{c}\text { Costa Norte, Cayo } \\
\text { Coco }\end{array}$ & $\left(22^{\circ} 34.04^{\prime} \mathrm{N}, 78^{\circ} 29.49^{\prime} \mathrm{W}\right)$ & $\mathrm{C}$ & Sig & N/A & Pérez-Cao (2004) & \\
\hline Feb-Dec 2000 & $\begin{array}{c}\text { Costa Norte, Cayo } \\
\text { Coco } \\
\end{array}$ & $\left(22^{\circ} 32.61^{\prime} \mathrm{N}, 78^{\circ} 26.29^{\prime} \mathrm{W}\right)$ & $\mathrm{C}$ & Sig & N/A & Pérez-Cao (2004) & \\
\hline Feb-Dec 2000 & $\begin{array}{c}\text { Costa Norte, Cayo } \\
\text { Coco }\end{array}$ & $\left(22^{\circ} 33.29^{\prime} \mathrm{N}, 78^{\circ} 25.37^{\prime} \mathrm{W}\right)$ & $\mathrm{C}$ & Sig & N/A & Pérez-Cao (2004) & \\
\hline Feb-Dec 2000 & $\begin{array}{c}\text { Costa Norte, Cayo } \\
\text { Coco }\end{array}$ & $\left(22^{\circ} 29.13^{\prime} \mathrm{N}, 78^{\circ} 18.27^{\prime} \mathrm{W}\right)$ & $\mathrm{C}$ & Sig & N/A & Pérez-Cao (2004) & \\
\hline Feb-Dec 2000 & $\begin{array}{c}\text { Costa Norte, Cayo } \\
\text { Coco }\end{array}$ & $\left(22^{\circ} 28.83^{\prime} \mathrm{N}, 78^{\circ} 17.99^{\prime} \mathrm{W}\right)$ & $\mathrm{C}$ & Sig & N/A & Pérez-Cao (2004) & \\
\hline Feb-Dec 2000 & $\begin{array}{c}\text { Bahía de Perros, } \\
\text { south of Cayo Coco }\end{array}$ & $\left(22^{\circ} 21.12^{\prime} \mathrm{N}, 78^{\circ} 33.40^{\prime} \mathrm{W}\right)$ & $\mathrm{C}$ & Sig & N/A & Pérez-Cao (2004) & \\
\hline Feb-Dec 2000 & $\begin{array}{c}\text { Bahía de Perros, } \\
\text { south of Cayo Coco }\end{array}$ & $\left(22^{\circ} 20.47^{\prime} \mathrm{N}, 78^{\circ} 33.32^{\prime} \mathrm{W}\right)$ & $\mathrm{C}$ & Sig & N/A & Pérez-Cao (2004) & \\
\hline Feb-Dec 2000 & $\begin{array}{c}\text { Bahía de Perros, } \\
\text { south of Cayo Coco }\end{array}$ & $\left(22^{\circ} 18.70^{\prime} \mathrm{N}, 78^{\circ} 30.07^{\prime} \mathrm{W}\right)$ & $\mathrm{C}$ & Sig & N/A & Pérez-Cao (2004) & \\
\hline Feb-Dec 2000 & $\begin{array}{l}\text { Bahía de Perros, } \\
\text { south of Cayo Coco }\end{array}$ & $\left(22^{\circ} 21.38^{\prime} \mathrm{N}, 78^{\circ} 35.87^{\prime} \mathrm{W}\right)$ & $\mathrm{C}$ & Sig & N/A & Pérez-Cao (2004) & \\
\hline 11 Jun 2002 & $\begin{array}{l}\text { Costa Norte, } \\
\text { Matanzas }\end{array}$ & $23^{\circ} 11.68^{\prime} \mathrm{N}, 81^{\circ} 07.73^{\prime} \mathrm{W}$ & $\mathrm{C}$ & Sig & 25 & $\begin{array}{l}\text { Pérez-Cao (2004; } \\
\text { 2009); López et al. } \\
\text { (in press) }\end{array}$ & \\
\hline 11 Jun 2002 & $\begin{array}{l}\text { Costa Norte, } \\
\text { Matanzas }\end{array}$ & $23^{\circ} 11.65^{\prime} \mathrm{N}, 81^{\circ} 05.68^{\prime} \mathrm{W}$ & $\mathrm{C}$ & Sig & 7 & $\begin{array}{l}\text { Pérez-Cao (2004; } \\
\text { 2009); López et al. } \\
\text { (in press) }\end{array}$ & \\
\hline 14 Jun 2002 & $\begin{array}{l}\text { Costa Norte, } \\
\text { Matanzas }\end{array}$ & $23^{\circ} 06.27^{\prime} \mathrm{N}, 81^{\circ} 18.32^{\prime} \mathrm{W}$ & $\mathrm{C}$ & Sig & 3 & $\begin{array}{l}\text { Pérez-Cao (2004; } \\
\text { 2009); López et al. } \\
\text { (in press) }\end{array}$ & \\
\hline 25 Aug 2002 & $\begin{array}{l}\text { Costa Norte, } \\
\text { Matanzas }\end{array}$ & $23^{\circ} 12.63^{\prime} \mathrm{N}, 81^{\circ} 05.49^{\prime} \mathrm{W}$ & $\mathrm{C}$ & Sig & 30 & $\begin{array}{l}\text { Pérez-Cao (2004; } \\
\text { 2009); López et al. } \\
\text { (in press) }\end{array}$ & \\
\hline 26 Aug 2002 & $\begin{array}{c}\text { Costa Norte, } \\
\text { Matanzas }\end{array}$ & $23^{\circ} 12.27^{\prime} \mathrm{N}, 81^{\circ} 05.37^{\prime} \mathrm{W}$ & $\mathrm{C}$ & Sig & 30 & $\begin{array}{l}\text { Pérez-Cao (2004; } \\
\text { 2009); López et al. } \\
\text { (in press) }\end{array}$ & \\
\hline 27 Aug 2002 & $\begin{array}{c}\text { Bahía de Cárdenas, } \\
\text { Matanzas }\end{array}$ & $23^{\circ} 12.50^{\prime} \mathrm{N}, 81^{\circ} 02.70^{\prime} \mathrm{W}$ & $\mathrm{C}$ & Sig & 10 & $\begin{array}{l}\text { Pérez-Cao (2004; } \\
\text { 2009); López et al. } \\
\text { (in press) }\end{array}$ & \\
\hline 27 Aug 2002 & $\begin{array}{c}\text { Costa Norte, } \\
\text { Matanzas }\end{array}$ & $23^{\circ} 11.88^{\prime} \mathrm{N}, 81^{\circ} 05.05^{\prime} \mathrm{W}$ & $\mathrm{C}$ & Sig & 6 & $\begin{array}{l}\text { Pérez-Cao (2004; } \\
\text { 2009); López et al. } \\
\text { (in press) }\end{array}$ & \\
\hline 27 Aug 2002 & $\begin{array}{c}\text { Costa Norte, } \\
\text { Matanzas }\end{array}$ & $23^{\circ} 11.53^{\prime} \mathrm{N}, 81^{\circ} 6.32^{\prime} \mathrm{W}$ & $\mathrm{C}$ & Sig & 3 & $\begin{array}{l}\text { Pérez-Cao (2004; } \\
\text { 2009); López et al. } \\
\text { (in press) }\end{array}$ & \\
\hline
\end{tabular}




\begin{tabular}{|c|c|c|c|c|c|c|c|}
\hline Species/Date & Location & Position & Status $^{a}$ & Type $^{b}$ & $\begin{array}{c}\text { Group } \\
\text { Size }\end{array}$ & Source $^{c}$ & Comments \\
\hline 28 Aug 2002 & $\begin{array}{l}\text { Cinco Leguas, } \\
\text { Matanzas }\end{array}$ & $23^{\circ} 12.98^{\prime} \mathrm{N}, 80^{\circ} 54.62^{\prime} \mathrm{W}$ & $\mathrm{C}$ & Sig & 1 & $\begin{array}{l}\text { Pérez-Cao (2004; 2009); } \\
\text { López et al. (in press) }\end{array}$ & \\
\hline 3 Dec 2002 & $\begin{array}{l}\text { Cinco Leguas, } \\
\text { Matanzas }\end{array}$ & $23^{\circ} 12.77^{\prime} \mathrm{N}, 80^{\circ} 55.92^{\prime} \mathrm{W}$ & $\mathrm{C}$ & Sig & 3 & $\begin{array}{l}\text { Pérez-Cao (2004; 2009); } \\
\text { López et al. (in press) }\end{array}$ & \\
\hline 5 Dec 2002 & $\begin{array}{l}\text { Cinco Leguas, } \\
\text { Matanzas }\end{array}$ & $23^{\circ} 12.07^{\prime} \mathrm{N}, 80^{\circ} 59.40^{\prime} \mathrm{W}$ & $\mathrm{C}$ & Sig & 3 & $\begin{array}{l}\text { Pérez-Cao (2004; 2009); } \\
\text { López et al. (in press) }\end{array}$ & \\
\hline 5 Dec 2002 & $\begin{array}{l}\text { Costa Norte, } \\
\text { Matanzas }\end{array}$ & $23^{\circ} 12.05^{\prime} \mathrm{N}, 81^{\circ} 60.33^{\prime} \mathrm{W}$ & $\mathrm{C}$ & Sig & 30 & $\begin{array}{c}\text { Pérez-Cao (2004; } \\
\text { 2009); López et al. (in } \\
\text { press) }\end{array}$ & \\
\hline 6 Dec 2002 & $\begin{array}{l}\text { Costa Norte, } \\
\text { Matanzas }\end{array}$ & $23^{\circ} 09.40^{\prime} \mathrm{N}, 81^{\circ} 15.58^{\prime} \mathrm{W}$ & $\mathrm{C}$ & Sig & 1 & $\begin{array}{c}\text { Pérez-Cao (2004; } \\
\text { 2009); López et al. (in } \\
\text { press) }\end{array}$ & \\
\hline 9 Mar 2003 & $\begin{array}{l}\text { Costa Norte, } \\
\text { Matanzas }\end{array}$ & $23^{\circ} 11.33^{\prime} \mathrm{N}, 81^{\circ} 13.62^{\prime} \mathrm{W}$ & $\mathrm{C}$ & Sig & 8 & $\begin{array}{l}\text { Pérez-Cao (2004; } \\
\text { 2009); López et al. (in } \\
\text { press) }\end{array}$ & \\
\hline 9 Mar 2003 & $\begin{array}{l}\text { Costa Norte, } \\
\text { Matanzas }\end{array}$ & $23^{\circ} 10.25^{\prime} \mathrm{N}, 81^{\circ} 13.98^{\prime} \mathrm{W}$ & $\mathrm{C}$ & Sig & 7 & $\begin{array}{l}\text { Pérez-Cao (2004; } \\
\text { 2009); López et al. (in } \\
\text { press) }\end{array}$ & \\
\hline 10 Mar 2003 & $\begin{array}{l}\text { Costa Norte, } \\
\text { Matanzas }\end{array}$ & $23^{\circ} 17.82^{\prime} \mathrm{N}, 80^{\circ} 58.37^{\prime} \mathrm{W}$ & $\mathrm{C}$ & Sig & 1 & $\begin{array}{c}\text { Pérez-Cao (2004; } \\
\text { 2009); López et al. (in } \\
\text { press) }\end{array}$ & \\
\hline 11 Mar 2003 & $\begin{array}{l}\text { Costa Norte, } \\
\text { Matanzas }\end{array}$ & $23^{\circ} 12.72^{\prime} \mathrm{N}, 81^{\circ} 30.52^{\prime} \mathrm{W}$ & $\mathrm{C}$ & Sig & 8 & $\begin{array}{c}\text { Pérez-Cao (2004; } \\
\text { 2009); López et al. (in } \\
\text { press) }\end{array}$ & \\
\hline 13 Mar 2003 & $\begin{array}{c}\text { Bahía de Cárdenas, } \\
\text { Matanzas }\end{array}$ & $23^{\circ} 11.43^{\prime} \mathrm{N}, 81^{\circ} 70.88^{\prime} \mathrm{W}$ & $\mathrm{C}$ & Sig & 6 & $\begin{array}{l}\text { Pérez-Cao (2004; } \\
\text { 2009); López et al. (in } \\
\text { press) }\end{array}$ & \\
\hline 13 Mar 2003 & $\begin{array}{c}\text { Bahía de Cárdenas, } \\
\text { Matanzas }\end{array}$ & $23^{\circ} 02.75^{\prime} \mathrm{N}, 81^{\circ} 11.67^{\prime} \mathrm{W}$ & $\mathrm{C}$ & Sig & 1 & $\begin{array}{c}\text { Pérez-Cao (2004; } \\
\text { 2009); López et al. (in } \\
\text { press) }\end{array}$ & \\
\hline 13 May 2003 & $\begin{array}{l}\text { Costa Norte, } \\
\text { Matanzas }\end{array}$ & $23^{\circ} 11.95^{\prime} \mathrm{N}, 81^{\circ} 40.95^{\prime} \mathrm{W}$ & C & Sig & 6 & $\begin{array}{l}\text { Pérez-Cao (2004; } \\
\text { 2009); López et al. (in } \\
\text { press) }\end{array}$ & \\
\hline 14 May 2003 & $\begin{array}{l}\text { Costa Norte, } \\
\text { Matanzas }\end{array}$ & $23^{\circ} 13.57^{\prime} \mathrm{N}, 81^{\circ} 60.13^{\prime} \mathrm{W}$ & $\mathrm{C}$ & Sig & 3 & $\begin{array}{c}\text { Pérez-Cao (2004; } \\
\text { 2009); López et al. (in } \\
\text { press) }\end{array}$ & \\
\hline $31 \mathrm{Jul} 2003$ & $\begin{array}{c}\text { Bahía de Cárdenas, } \\
\text { Matanzas }\end{array}$ & $23^{\circ} 04.33^{\prime} \mathrm{N}, 81^{\circ} 90.52^{\prime} \mathrm{W}$ & $\mathrm{C}$ & Sig & 6 & $\begin{array}{c}\text { Pérez-Cao (2004; } \\
\text { 2009); López et al. (in } \\
\text { press) }\end{array}$ & \\
\hline 1 Aug 2003 & $\begin{array}{l}\text { Costa Norte, } \\
\text { Matanzas }\end{array}$ & $23^{\circ} 12.90^{\prime} \mathrm{N}, 81^{\circ} 50.45^{\prime} \mathrm{W}$ & $\mathrm{C}$ & Sig & 1 & $\begin{array}{l}\text { Pérez-Cao (2004; } \\
\text { 2009); López et al. (in } \\
\text { press) }\end{array}$ & \\
\hline 1 Aug 2003 & $\begin{array}{l}\text { Costa Norte, } \\
\text { Matanzas }\end{array}$ & $23^{\circ} 12.48^{\prime} \mathrm{N}, 81^{\circ} 60.95^{\prime} \mathrm{W}$ & C & Sig & 12 & $\begin{array}{c}\text { Pérez-Cao (2004; } \\
\text { 2009); López et al. (in } \\
\text { press) }\end{array}$ & \\
\hline 1 Aug 2003 & $\begin{array}{l}\text { Costa Norte, } \\
\text { Matanzas }\end{array}$ & $23^{\circ} 12.15^{\prime} \mathrm{N}, 81^{\circ} 10.93^{\prime} \mathrm{W}$ & $\mathrm{C}$ & Sig & 5 & $\begin{array}{c}\text { Pérez-Cao (2004; } \\
\text { 2009); López et al. (in } \\
\text { press) }\end{array}$ & \\
\hline 1 Aug 2003 & $\begin{array}{l}\text { Costa Norte, } \\
\text { Matanzas }\end{array}$ & $23^{\circ} 12.10^{\prime} \mathrm{N}, 81^{\circ} 30.95^{\prime} \mathrm{W}$ & $\mathrm{C}$ & Sig & 15 & $\begin{array}{c}\text { Pérez-Cao (2004; } \\
\text { 2009); López et al. (in } \\
\text { press) }\end{array}$ & \\
\hline 2 Aug 2003 & $\begin{array}{l}\text { Costa Norte, } \\
\text { Matanzas }\end{array}$ & $23^{\circ} 11.77^{\prime} \mathrm{N}, 81^{\circ} 60.45^{\prime} \mathrm{W}$ & $\mathrm{C}$ & Sig & 8 & $\begin{array}{c}\text { Pérez-Cao (2004; } \\
\text { 2009); López et al. (in } \\
\text { press) }\end{array}$ & \\
\hline 3 Aug 2003 & $\begin{array}{l}\text { Cinco Leguas, } \\
\text { Matanzas }\end{array}$ & $23^{\circ} 11.57^{\prime} \mathrm{N}, 81^{\circ} 00.15^{\prime} \mathrm{W}$ & $\mathrm{C}$ & Sig & 3 & $\begin{array}{c}\text { Pérez-Cao (2004; } \\
\text { 2009); López et al. (in } \\
\text { press) }\end{array}$ & \\
\hline 3 Aug 2003 & $\begin{array}{l}\text { Costa Norte, } \\
\text { Matanzas }\end{array}$ & $23^{\circ} 12.55^{\prime} \mathrm{N}, 81^{\circ} 40.38^{\prime} \mathrm{W}$ & $\mathrm{C}$ & Sig & 2 & $\begin{array}{c}\text { Pérez-Cao (2004; } \\
\text { 2009); López et al. (in } \\
\text { press) }\end{array}$ & \\
\hline 3 Aug 2003 & $\begin{array}{l}\text { Costa Norte, } \\
\text { Matanzas }\end{array}$ & $23^{\circ} 12.78^{\prime} \mathrm{N}, 81^{\circ} 40.52^{\prime} \mathrm{W}$ & $\mathrm{C}$ & Sig & 3 & $\begin{array}{c}\text { Pérez-Cao (2004; } \\
\text { 2009); López et al. (in } \\
\text { press) }\end{array}$ & \\
\hline 3 Aug 2003 & $\begin{array}{l}\text { Costa Norte, } \\
\text { Matanzas }\end{array}$ & $23^{\circ} 13.72^{\prime} \mathrm{N}, 81^{\circ} 30.13^{\prime} \mathrm{W}$ & $\mathrm{C}$ & Sig & 1 & $\begin{array}{c}\text { Pérez-Cao (2004; } \\
\text { 2009); López et al. (in } \\
\text { press) }\end{array}$ & \\
\hline
\end{tabular}




\begin{tabular}{|c|c|c|c|c|c|c|c|}
\hline Species/Date & Location & Position & Status $^{a}$ & Type $^{\mathrm{b}}$ & $\begin{array}{c}\text { Group } \\
\text { Size }\end{array}$ & Source $^{c}$ & Comments \\
\hline 3 Aug 2003 & $\begin{array}{l}\text { Costa Norte, } \\
\text { Matanzas }\end{array}$ & $23^{\circ} 14.37^{\prime} \mathrm{N}, 81^{\circ} 40.47^{\prime} \mathrm{W}$ & C & Sig & 3 & $\begin{array}{l}\text { Pérez-Cao (2004; } \\
\text { 2009); López et al. } \\
\text { (in press) }\end{array}$ & \\
\hline $22 \mathrm{Feb} 2004$ & $\begin{array}{c}\text { Bahía de Cárdenas, } \\
\text { Matanzas }\end{array}$ & $23^{\circ} 06.78^{\prime} \mathrm{N}, 81^{\circ} 90.47^{\prime} \mathrm{W}$ & $\mathrm{C}$ & Sig & 3 & $\begin{array}{l}\text { Pérez-Cao (2004); } \\
\text { López et al. (in } \\
\text { press) }\end{array}$ & \\
\hline 7 Jul 2004 & $\begin{array}{l}\text { Costa Norte, } \\
\text { Matanzas }\end{array}$ & $23^{\circ} 12.78^{\prime} \mathrm{N}, 81^{\circ} 30.88^{\prime} \mathrm{W}$ & $\mathrm{C}$ & Sig & 7 & $\begin{array}{l}\text { Pérez-Cao (2004); } \\
\text { López et al. (in } \\
\text { press) }\end{array}$ & \\
\hline 9 Jul 2004 & $\begin{array}{l}\text { Costa Norte, } \\
\text { Matanzas }\end{array}$ & $23^{\circ} 12.78^{\prime} \mathrm{N}, 81^{\circ} 40.38^{\prime} \mathrm{W}$ & $\mathrm{C}$ & Sig & 15 & $\begin{array}{l}\text { Pérez-Cao (2004); } \\
\text { López et al. } \\
\text { (in press) }\end{array}$ & \\
\hline 23 Sept 2004 & $\begin{array}{l}\text { Costa Norte, } \\
\text { Matanzas }\end{array}$ & $23^{\circ} 10.43^{\prime} \mathrm{N}, 81^{\circ} 13.73^{\prime} \mathrm{W}$ & $\mathrm{C}$ & Sig & 2 & $\begin{array}{l}\text { López et al. } \\
\text { (in press) }\end{array}$ & \\
\hline 23 Sept 2004 & $\begin{array}{l}\text { Costa Norte, } \\
\text { Matanzas }\end{array}$ & $23^{\circ} 08.48^{\prime} \mathrm{N}, 81^{\circ} 16.17^{\prime} \mathrm{W}$ & $\mathrm{C}$ & Sig & 25 & $\begin{array}{l}\text { López et al. } \\
\text { (in press) }\end{array}$ & \\
\hline 25 Sept 2004 & $\begin{array}{c}\text { Costa Norte, } \\
\text { Matanzas }\end{array}$ & $23^{\circ} 08.33^{\prime} \mathrm{N}, 81^{\circ} 18.17^{\prime} \mathrm{W}$ & $\mathrm{C}$ & Sig & 2 & $\begin{array}{l}\text { López et al. } \\
\text { (in press) }\end{array}$ & \\
\hline 26 Aug 2005 & $\begin{array}{c}\text { Bahía de Cárdenas, } \\
\text { Matanzas }\end{array}$ & $23^{\circ} 11.35^{\prime} \mathrm{N}, 81^{\circ} 80.10^{\prime} \mathrm{W}$ & $\mathrm{C}$ & Sig & 15 & $\begin{array}{l}\text { López et al. } \\
\text { (in press) }\end{array}$ & \\
\hline 26 Aug 2005 & $\begin{array}{c}\text { Costa Norte, } \\
\text { Matanzas }\end{array}$ & $23^{\circ} 14.53^{\prime} \mathrm{N}, 81^{\circ} 50.70^{\prime} \mathrm{W}$ & $\mathrm{C}$ & Sig & 2 & $\begin{array}{l}\text { López et al. } \\
\text { (in press) }\end{array}$ & \\
\hline 28 Aug 2005 & $\begin{array}{l}\text { Costa Norte, } \\
\text { Matanzas }\end{array}$ & $23^{\circ} 09.52^{\prime} \mathrm{N}, 81^{\circ} 26.58^{\prime} \mathrm{W}$ & $\mathrm{C}$ & Sig & 7 & $\begin{array}{l}\text { López et al. } \\
\text { (in press) }\end{array}$ & \\
\hline 28 Aug 2005 & $\begin{array}{l}\text { Costa Norte, } \\
\text { Matanzas }\end{array}$ & $23^{\circ} 11.07^{\prime} \mathrm{N}, 81^{\circ} 14.60^{\circ} \mathrm{W}$ & $\mathrm{C}$ & Sig & 5 & $\begin{array}{l}\text { López et al. } \\
\text { (in press) }\end{array}$ & \\
\hline 28 Aug 2005 & $\begin{array}{l}\text { Costa Norte, } \\
\text { Matanzas }\end{array}$ & $23^{\circ} 10.27^{\prime} \mathrm{N}, 81^{\circ} 15.85^{\circ} \mathrm{W}$ & $\mathrm{C}$ & Sig & 1 & $\begin{array}{l}\text { López et al. } \\
\text { (in press) }\end{array}$ & \\
\hline 29 Aug 2005 & $\begin{array}{l}\text { Costa Norte, } \\
\text { Matanzas }\end{array}$ & $23^{\circ} 08.83^{\prime} \mathrm{N}, 81^{\circ} 17.68^{\prime} \mathrm{W}$ & $\mathrm{C}$ & Sig & 12 & $\begin{array}{l}\text { López et al. } \\
\text { (in press) }\end{array}$ & \\
\hline 29 Aug 2005 & $\begin{array}{c}\text { Bahía de Cárdenas, } \\
\text { Matanzas }\end{array}$ & $23^{\circ} 09.63^{\prime} \mathrm{N}, 81^{\circ} 10.27^{\prime} \mathrm{W}$ & $\mathrm{C}$ & Sig & 1 & $\begin{array}{l}\text { López et al. } \\
\text { (in press) }\end{array}$ & \\
\hline 10 Nov 2005 & $\begin{array}{c}\text { Costa Norte, } \\
\text { Matanzas }\end{array}$ & $23^{\circ} 08.18^{\prime} \mathrm{N}, 81^{\circ} 18.93^{\prime} \mathrm{W}$ & $\mathrm{C}$ & Sig & 1 & $\begin{array}{l}\text { López et al. } \\
\text { (in press) }\end{array}$ & \\
\hline 10 Nov 2005 & $\begin{array}{l}\text { Costa Norte, } \\
\text { Matanzas }\end{array}$ & $23^{\circ} 08.58^{\prime} \mathrm{N}, 81^{\circ} 17.77^{\prime} \mathrm{W}$ & $\mathrm{C}$ & Sig & 4 & $\begin{array}{l}\text { López et al. } \\
\text { (in press) }\end{array}$ & \\
\hline 10 Nov 2005 & $\begin{array}{l}\text { Costa Norte, } \\
\text { Matanzas }\end{array}$ & $23^{\circ} 09.10^{\prime} \mathrm{N}, 81^{\circ} 17.18^{\prime} \mathrm{W}$ & $\mathrm{C}$ & Sig & 1 & $\begin{array}{l}\text { López et al. } \\
\text { (in press) }\end{array}$ & \\
\hline 10 Nov 2005 & $\begin{array}{l}\text { Costa Norte, } \\
\text { Matanzas }\end{array}$ & $23^{\circ} 15.87^{\prime} \mathrm{N}, 81^{\circ} 10.50^{\circ} \mathrm{W}$ & $\mathrm{C}$ & Sig & 12 & $\begin{array}{l}\text { López et al. } \\
\text { (in press) }\end{array}$ & \\
\hline 12 Nov 2005 & $\begin{array}{l}\text { Costa Norte, } \\
\text { Matanzas }\end{array}$ & $23^{\circ} 10.38^{\prime} \mathrm{N}, 81^{\circ} 15.95^{\circ} \mathrm{W}$ & $\mathrm{C}$ & Sig & 15 & $\begin{array}{l}\text { López et al. } \\
\text { (in press) }\end{array}$ & \\
\hline 13 Nov 2005 & $\begin{array}{l}\text { Costa Norte, } \\
\text { Matanzas }\end{array}$ & $23^{\circ} 13.35^{\prime} \mathrm{N}, 81^{\circ} 90.40^{\circ} \mathrm{W}$ & $\mathrm{C}$ & Sig & 4 & $\begin{array}{l}\text { López et al. } \\
\text { (in press) }\end{array}$ & \\
\hline 13 Nov 2005 & $\begin{array}{l}\text { Costa Norte, } \\
\text { Matanzas }\end{array}$ & $23^{\circ} 09.05^{\prime} \mathrm{N}, 81^{\circ} 18.32^{\prime} \mathrm{W}$ & $\mathrm{C}$ & Sig & 2 & $\begin{array}{l}\text { López et al. } \\
\text { (in press) }\end{array}$ & \\
\hline $2005-2006$ & $\begin{array}{l}\text { Las Picúas Cayos- } \\
\text { Cristo Marine } \\
\text { Protected Area }\end{array}$ & $\left(23^{\circ} 06.30^{\prime} \mathrm{N}, 80^{\circ} 17.95^{\prime} \mathrm{W}\right)$ & $\mathrm{C}$ & Sig & N/A & $\begin{array}{l}\text { Alvarez Alemán } e t \\
\text { al. }(2009)^{\mathrm{w}}\end{array}$ & \\
\hline $2005-2006$ & $\begin{array}{c}\text { Las Picúas Cayos- } \\
\text { Cristo Marine } \\
\text { Protected Area } \\
\end{array}$ & $\left(23^{\circ} 05.88^{\prime} \mathrm{N}, 80^{\circ} 16.36^{\circ} \mathrm{W}\right)$ & $\mathrm{C}$ & Sig & N/A & $\begin{array}{l}\text { Alvarez Alemán et } \\
\text { al. (2009) }\end{array}$ & \\
\hline $2005-2006$ & $\begin{array}{l}\text { Las Picúas Cayos- } \\
\text { Cristo Marine } \\
\text { Protected Area }\end{array}$ & $\left(23^{\circ} 03.93^{\prime} \mathrm{N}, 80^{\circ} 17.19^{\prime} \mathrm{W}\right)$ & $\mathrm{C}$ & Sig & N/A & $\begin{array}{c}\text { Alvarez Alemán } e t \\
\text { al. (2009) }\end{array}$ & \\
\hline $2005-2006$ & $\begin{array}{l}\text { Las Picúas Cayos- } \\
\text { Cristo Marine } \\
\text { Protected Area }\end{array}$ & $\left(23^{\circ} 03.53^{\prime} \mathrm{N}, 80^{\circ} 17.15^{\prime} \mathrm{W}\right)$ & $\mathrm{C}$ & Sig & N/A & $\begin{array}{l}\text { Alvarez Alemán et } \\
\text { al. (2009) }\end{array}$ & \\
\hline $2005-2006$ & $\begin{array}{l}\text { Las Picúas Cayos- } \\
\text { Cristo Marine } \\
\text { Protected Area }\end{array}$ & $\left(23^{\circ} 03.53^{\prime} \mathrm{N}, 80^{\circ} 16.53^{\prime} \mathrm{W}\right)$ & $\mathrm{C}$ & Sig & N/A & $\begin{array}{l}\text { Alvarez Alemán } e t \\
\text { al. (2009) }\end{array}$ & \\
\hline $2005-2006$ & $\begin{array}{l}\text { Las Picúas Cayos- } \\
\text { Cristo Marine } \\
\text { Protected Area }\end{array}$ & $\left(23^{\circ} 03.84^{\prime} \mathrm{N}, 80^{\circ} 14.36^{\circ} \mathrm{W}\right)$ & $\mathrm{C}$ & Sig & N/A & $\begin{array}{l}\text { Alvarez Alemán et } \\
\text { al. (2009) }\end{array}$ & \\
\hline $2005-2006$ & $\begin{array}{l}\text { Las Picúas Cayos- } \\
\text { Cristo Marine } \\
\text { Protected Area }\end{array}$ & $\left(23^{\circ} 03.33^{\prime} \mathrm{N}, 80^{\circ} 20.19^{\prime} \mathrm{W}\right)$ & $\mathrm{C}$ & Sig & N/A & $\begin{array}{l}\text { Alvarez Alemán et } \\
\text { al. (2009) }\end{array}$ & \\
\hline
\end{tabular}




\begin{tabular}{|c|c|c|c|c|c|c|c|}
\hline Species/Date & Location & Position & Status $^{a}$ & Type $^{b}$ & $\begin{array}{l}\text { Group } \\
\text { Size }\end{array}$ & Source $^{c}$ & Comments \\
\hline $2005-2006$ & $\begin{array}{l}\text { Las Picúas Cayos- } \\
\text { Cristo Marine } \\
\text { Protected Area }\end{array}$ & $\left(23^{\circ} 02.41^{\prime} \mathrm{N}, 80^{\circ} 18.18^{\prime} \mathrm{W}\right)$ & $\mathrm{C}$ & Sig & N/A & $\begin{array}{c}\text { Alvarez Alemán et } \\
\text { al. (2009) }\end{array}$ & \\
\hline $2005-2006$ & $\begin{array}{l}\text { Las Picúas Cayos- } \\
\text { Cristo Marine } \\
\text { Protected Area }\end{array}$ & $\left(23^{\circ} 02.43^{\prime} \mathrm{N}, 80^{\circ} 17.95^{\prime} \mathrm{W}\right)$ & $\mathrm{C}$ & Sig & N/A & $\begin{array}{l}\text { Alvarez Alemán et } \\
\text { al. (2009) }\end{array}$ & \\
\hline $2005-2006$ & $\begin{array}{l}\text { Las Picúas Cayos- } \\
\text { Cristo Marine } \\
\text { Protected Area }\end{array}$ & $\left(23^{\circ} 02.14^{\prime} \mathrm{N}, 80^{\circ} 18.02^{\prime} \mathrm{W}\right)$ & $\mathrm{C}$ & Sig & N/A & $\begin{array}{l}\text { Alvarez Alemán } e t \\
\text { al. (2009) }\end{array}$ & \\
\hline $2005-2006$ & $\begin{array}{l}\text { Las Picúas Cayos- } \\
\text { Cristo Marine } \\
\text { Protected Area }\end{array}$ & $\left(23^{\circ} 01.40^{\prime} \mathrm{N}, 80^{\circ} 19.05^{\prime} \mathrm{W}\right)$ & $\mathrm{C}$ & Sig & N/A & $\begin{array}{l}\text { Alvarez Alemán et } \\
\text { al. (2009) }\end{array}$ & \\
\hline $2005-2006$ & $\begin{array}{l}\text { Las Picúas Cayos- } \\
\text { Cristo Marine } \\
\text { Protected Area }\end{array}$ & $\left(23^{\circ} 05.86^{\prime} \mathrm{N}, 80^{\circ} 13.69^{\prime} \mathrm{W}\right)$ & C & Sig & N/A & $\begin{array}{l}\text { Alvarez Alemán et } \\
\text { al. (2009) }\end{array}$ & \\
\hline $2005-2006$ & $\begin{array}{l}\text { Las Picúas Cayos- } \\
\text { Cristo Marine } \\
\text { Protected Area }\end{array}$ & $\left(22^{\circ} 58.19^{\prime} \mathrm{N}, 80^{\circ} 11.61^{\prime} \mathrm{W}\right)$ & $\mathrm{C}$ & Sig & N/A & $\begin{array}{l}\text { Alvarez Alemán } e t \\
\text { al. (2009) }\end{array}$ & \\
\hline $2005-2006$ & $\begin{array}{c}\text { Las Picúas Cayos- } \\
\text { Cristo Marine } \\
\text { Protected Area }\end{array}$ & $\left(22^{\circ} 57.73^{\prime} \mathrm{N}, 80^{\circ} 12.54^{\prime} \mathrm{W}\right)$ & $\mathrm{C}$ & Sig & N/A & $\begin{array}{l}\text { Alvarez Alemán } e t \\
\text { al. (2009) }\end{array}$ & \\
\hline $2005-2006$ & $\begin{array}{l}\text { Las Picúas Cayos- } \\
\text { Cristo Marine } \\
\text { Protected Area }\end{array}$ & $\left(22^{\circ} 57.30^{\prime} \mathrm{N}, 80^{\circ} 11.64^{\prime} \mathrm{W}\right)$ & $\mathrm{C}$ & Sig & N/A & $\begin{array}{l}\text { Alvarez Alemán et } \\
\text { al. (2009) }\end{array}$ & \\
\hline $2005-2006$ & $\begin{array}{l}\text { Las Picúas Cayos- } \\
\text { Cristo Marine } \\
\text { Protected Area }\end{array}$ & $\left(22^{\circ} 57.43^{\prime} \mathrm{N}, 80^{\circ} 12.72^{\prime} \mathrm{W}\right)$ & $\mathrm{C}$ & Sig & N/A & $\begin{array}{c}\text { Alvarez Alemán } e t \\
\text { al. (2009) }\end{array}$ & \\
\hline $2005-2006$ & $\begin{array}{l}\text { Las Picúas Cayos- } \\
\text { Cristo Marine } \\
\text { Protected Area }\end{array}$ & $\left(22^{\circ} 57.24^{\prime} \mathrm{N}, 80^{\circ} 12.67^{\prime} \mathrm{W}\right)$ & $\mathrm{C}$ & Sig & N/A & $\begin{array}{l}\text { Alvarez Alemán et } \\
\text { al. (2009) }\end{array}$ & \\
\hline $2005-2006$ & $\begin{array}{l}\text { Las Picúas Cayos- } \\
\text { Cristo Marine } \\
\text { Protected Area }\end{array}$ & $\left(22^{\circ} 57.08^{\prime} \mathrm{N}, 80^{\circ} 12.84^{\prime} \mathrm{W}\right)$ & $\mathrm{C}$ & Sig & N/A & $\begin{array}{l}\text { Alvarez Alemán } e t \\
\text { al. (2009) }\end{array}$ & \\
\hline $2005-2006$ & $\begin{array}{l}\text { Las Picúas Cayos- } \\
\text { Cristo Marine } \\
\text { Protected Area }\end{array}$ & $\left(22^{\circ} 57.05^{\prime} \mathrm{N}, 80^{\circ} 12.74^{\prime} \mathrm{W}\right)$ & C & Sig & N/A & $\begin{array}{c}\text { Alvarez Alemán } e t \\
\text { al. (2009) }\end{array}$ & \\
\hline $2005-2006$ & $\begin{array}{l}\text { Las Picúas Cayos- } \\
\text { Cristo Marine } \\
\text { Protected Area }\end{array}$ & $\left(22^{\circ} 56.89^{\prime} \mathrm{N}, 80^{\circ} 12.75^{\prime} \mathrm{W}\right)$ & $\mathrm{C}$ & Sig & N/A & $\begin{array}{l}\text { Alvarez Alemán } e t \\
\text { al. (2009) }\end{array}$ & \\
\hline $2005-2006$ & $\begin{array}{l}\text { Las Picúas Cayos- } \\
\text { Cristo Marine } \\
\text { Protected Area }\end{array}$ & $\left(22^{\circ} 56.76^{\prime} \mathrm{N}, 80^{\circ} 12.48^{\prime} \mathrm{W}\right)$ & $\mathrm{C}$ & Sig & N/A & $\begin{array}{l}\text { Alvarez Alemán } \\
\text { et al. (2009) }\end{array}$ & \\
\hline $2005-2006$ & $\begin{array}{l}\text { Las Picúas Cayos- } \\
\text { Cristo Marine } \\
\text { Protected Area }\end{array}$ & $\left(22^{\circ} 56.67^{\prime} \mathrm{N}, 80^{\circ} 12.80^{\prime} \mathrm{W}\right)$ & $\mathrm{C}$ & Sig & N/A & $\begin{array}{c}\text { Alvarez Alemán } e t \\
\text { al. (2009) }\end{array}$ & \\
\hline $2005-2006$ & $\begin{array}{c}\text { Las Picúas Cayos- } \\
\text { Cristo Marine } \\
\text { Protected Area }\end{array}$ & $\left(22^{\circ} 56.62^{\prime} \mathrm{N}, 80^{\circ} 14.37^{\prime} \mathrm{W}\right)$ & $\mathrm{C}$ & Sig & N/A & $\begin{array}{l}\text { Alvarez Alemán et } \\
\text { al. (2009) }\end{array}$ & \\
\hline $2005-2006$ & $\begin{array}{l}\text { Las Picúas Cayos- } \\
\text { Cristo Marine } \\
\text { Protected Area }\end{array}$ & $\left(22^{\circ} 56.51^{\prime} \mathrm{N}, 80^{\circ} 13.96^{\prime} \mathrm{W}\right)$ & $\mathrm{C}$ & Sig & N/A & $\begin{array}{l}\text { Alvarez Alemán } e t \\
\text { al. (2009) }\end{array}$ & \\
\hline $2005-2006$ & $\begin{array}{l}\text { Las Picúas Cayos- } \\
\text { Cristo Marine } \\
\text { Protected Area }\end{array}$ & $\left(22^{\circ} 56.23^{\prime} \mathrm{N}, 80^{\circ} 11.51^{\prime} \mathrm{W}\right)$ & $\mathrm{C}$ & Sig & $\mathrm{N} / \mathrm{A}$ & $\begin{array}{l}\text { Alvarez Alemán } e t \\
\text { al. (2009) }\end{array}$ & \\
\hline $2005-2006$ & $\begin{array}{l}\text { Las Picúas Cayos- } \\
\text { Cristo Marine } \\
\text { Protected Area }\end{array}$ & $\left(22^{\circ} 55.62^{\prime} \mathrm{N}, 80^{\circ} 12.82^{\prime} \mathrm{W}\right)$ & $\mathrm{C}$ & Sig & N/A & $\begin{array}{l}\text { Alvarez Alemán et } \\
\text { al. (2009) }\end{array}$ & \\
\hline $2005-2006$ & $\begin{array}{l}\text { Las Picúas Cayos- } \\
\text { Cristo Marine } \\
\text { Protected Area }\end{array}$ & $\left(22^{\circ} 56.13^{\prime} \mathrm{N}, 80^{\circ} 13.97^{\prime} \mathrm{W}\right)$ & $\mathrm{C}$ & Sig & N/A & $\begin{array}{l}\text { Alvarez Alemán } e t \\
\text { al. (2009) }\end{array}$ & \\
\hline $2005-2006$ & $\begin{array}{l}\text { Las Picúas Cayos- } \\
\text { Cristo Marine } \\
\text { Protected Area }\end{array}$ & $\left(22^{\circ} 56.00^{\prime} \mathrm{N}, 80^{\circ} 14.13^{\prime} \mathrm{W}\right)$ & $\mathrm{C}$ & Sig & N/A & $\begin{array}{c}\text { Alvarez Alemán } e t \\
\text { al. (2009) }\end{array}$ & \\
\hline $2005-2006$ & $\begin{array}{l}\text { Las Picúas Cayos- } \\
\text { Cristo Marine } \\
\text { Protected Area }\end{array}$ & $\left(22^{\circ} 56.00^{\prime} \mathrm{N}, 80^{\circ} 14.28^{\prime} \mathrm{W}\right)$ & $\mathrm{C}$ & Sig & N/A & $\begin{array}{l}\text { Alvarez Alemán } e t \\
\text { al. (2009) }\end{array}$ & \\
\hline
\end{tabular}




\begin{tabular}{|c|c|c|c|c|c|c|c|}
\hline Species/Date & Location & Position & Status $^{\mathrm{a}}$ & Type $^{b}$ & $\begin{array}{l}\text { Group } \\
\text { Size }\end{array}$ & Source $^{c}$ & Comments \\
\hline 2005-2006 & $\begin{array}{c}\text { Las Picúas Cayos- } \\
\text { Cristo Marine } \\
\text { Protected Area }\end{array}$ & $\left(22^{\circ} 56.01^{\prime} \mathrm{N}, 80^{\circ} 15.37^{\prime} \mathrm{W}\right)$ & $\mathrm{C}$ & Sig & N/A & $\begin{array}{c}\text { Alvarez Alemán et } \\
\text { al. (2009) }\end{array}$ & \\
\hline $2005-2006$ & $\begin{array}{c}\text { Las Picúas Cayos- } \\
\text { Cristo Marine } \\
\text { Protected Area }\end{array}$ & $\left(22^{\circ} 55.97^{\prime} \mathrm{N}, 80^{\circ} 15.58^{\prime} \mathrm{W}\right)$ & $\mathrm{C}$ & Sig & N/A & $\begin{array}{c}\text { Alvarez Alemán et } \\
\text { al. (2009) }\end{array}$ & \\
\hline $2005-2006$ & $\begin{array}{c}\text { Las Picúas Cayos- } \\
\text { Cristo Marine } \\
\text { Protected Area }\end{array}$ & $\left(22^{\circ} 55.02^{\prime} \mathrm{N}, 80^{\circ} 17.48^{\prime} \mathrm{W}\right)$ & $\mathrm{C}$ & Sig & N/A & $\begin{array}{c}\text { Alvarez Alemán et } \\
\text { al. (2009) }\end{array}$ & \\
\hline $2005-2006$ & $\begin{array}{c}\text { Las Picúas Cayos- } \\
\text { Cristo Marine } \\
\text { Protected Area }\end{array}$ & $\left(22^{\circ} 55.17^{\prime} \mathrm{N}, 80^{\circ} 17.77^{\prime} \mathrm{W}\right)$ & $\mathrm{C}$ & Sig & N/A & $\begin{array}{c}\text { Alvarez Alemán et } \\
\text { al. (2009) }\end{array}$ & \\
\hline $2005-2006$ & $\begin{array}{c}\text { Las Picúas Cayos- } \\
\text { Cristo Marine } \\
\text { Protected Area }\end{array}$ & $\left(22^{\circ} 55.27^{\prime} \mathrm{N}, 80^{\circ} 17.82^{\prime} \mathrm{W}\right)$ & $\mathrm{C}$ & Sig & N/A & $\begin{array}{c}\text { Alvarez Alemán et } \\
\text { al. (2009) }\end{array}$ & \\
\hline $2005-2006$ & $\begin{array}{c}\text { Las Picúas Cayos- } \\
\text { Cristo Marine } \\
\text { Protected Area }\end{array}$ & $\left(22^{\circ} 55.98^{\prime} \mathrm{N}, 80^{\circ} 18.13^{\prime} \mathrm{W}\right)$ & $\mathrm{C}$ & Sig & N/A & $\begin{array}{c}\text { Alvarez Alemán } e t \\
\text { al. (2009) }\end{array}$ & \\
\hline $2005-2006$ & $\begin{array}{c}\text { Las Picúas Cayos- } \\
\text { Cristo Marine } \\
\text { Protected Area }\end{array}$ & $\left(22^{\circ} 56.04^{\prime} \mathrm{N}, 80^{\circ} 18.04^{\prime} \mathrm{W}\right)$ & $\mathrm{C}$ & Sig & N/A & $\begin{array}{c}\text { Alvarez Alemán et } \\
\text { al. (2009) }\end{array}$ & \\
\hline $2005-2006$ & $\begin{array}{c}\text { Las Picúas Cayos- } \\
\text { Cristo Marine } \\
\text { Protected Area }\end{array}$ & $\left(22^{\circ} 55.97^{\prime} \mathrm{N}, 80^{\circ} 18.46^{\prime} \mathrm{W}\right)$ & $\mathrm{C}$ & Sig & N/A & $\begin{array}{c}\text { Alvarez Alemán et } \\
\text { al. (2009) }\end{array}$ & \\
\hline $2005-2006$ & $\begin{array}{c}\text { Las Picúas Cayos- } \\
\text { Cristo Marine } \\
\text { Protected Area }\end{array}$ & $\left(22^{\circ} 55.61^{\prime} \mathrm{N}, 80^{\circ} 18.51^{\prime} \mathrm{W}\right)$ & $\mathrm{C}$ & Sig & N/A & $\begin{array}{c}\text { Alvarez Alemán et } \\
\text { al. (2009) }\end{array}$ & \\
\hline $12 \mathrm{Jul} 2006$ & $\begin{array}{c}\text { Costa Norte, } \\
\text { Matanzas }\end{array}$ & $23^{\circ} 12.22^{\prime} \mathrm{N}, 81^{\circ} 13.47^{\prime} \mathrm{W}$ & $\mathrm{C}$ & Sig & 13 & $\begin{array}{l}\text { López et al. } \\
\text { (in press) }\end{array}$ & \\
\hline $12 \mathrm{Jul} 2006$ & $\begin{array}{c}\text { Costa Norte, } \\
\text { Matanzas }\end{array}$ & $23^{\circ} 12.62^{\prime} \mathrm{N}, 81^{\circ} 40.18^{\prime} \mathrm{W}$ & $\mathrm{C}$ & Sig & 5 & $\begin{array}{l}\text { López et al. } \\
\text { (in press) }\end{array}$ & \\
\hline $12 \mathrm{Jul} 2006$ & $\begin{array}{c}\text { Costa Norte, } \\
\text { Matanzas }\end{array}$ & $23^{\circ} 12.85^{\prime} \mathrm{N}, 81^{\circ} 40.73^{\prime} \mathrm{W}$ & $\mathrm{C}$ & Sig & 4 & $\begin{array}{l}\text { López et al. } \\
\text { (in press) }\end{array}$ & \\
\hline $13 \mathrm{Jul} 2006$ & $\begin{array}{c}\text { Bahía de Cárdenas, } \\
\text { Matanzas }\end{array}$ & $23^{\circ} 09.68^{\prime} \mathrm{N}, 81^{\circ} 70.07^{\prime} \mathrm{W}$ & $\mathrm{C}$ & Sig & 4 & $\begin{array}{l}\text { López et al. } \\
\text { (in press) }\end{array}$ & \\
\hline $14 \mathrm{Jul} 2006$ & $\begin{array}{c}\text { Costa Norte, } \\
\text { Matanzas }\end{array}$ & $23^{\circ} 07.65^{\prime} \mathrm{N}, 81^{\circ} 18.63^{\prime} \mathrm{W}$ & $\mathrm{C}$ & Sig & 3 & $\begin{array}{l}\text { López et al. } \\
\text { (in press) }\end{array}$ & \\
\hline $16 \mathrm{Jul} 2006$ & $\begin{array}{c}\text { Costa Norte, } \\
\text { Matanzas }\end{array}$ & $23^{\circ} 07.63^{\prime} \mathrm{N}, 81^{\circ} 18.43^{\prime} \mathrm{W}$ & $\mathrm{C}$ & Sig & 12 & $\begin{array}{l}\text { López et al. } \\
\text { (in press) }\end{array}$ & \\
\hline 16 Jul 2006 & $\begin{array}{c}\text { Costa Norte, } \\
\text { Matanzas }\end{array}$ & $23^{\circ} 09.30^{\prime} \mathrm{N}, 81^{\circ} 15.20^{\prime} \mathrm{W}$ & $\mathrm{C}$ & Sig & 6 & $\begin{array}{l}\text { López et al. } \\
\text { (in press) }\end{array}$ & \\
\hline $17 \mathrm{Jul} 2006$ & $\begin{array}{c}\text { Costa Norte, } \\
\text { Matanzas }\end{array}$ & $23^{\circ} 07.63^{\prime} \mathrm{N}, 81^{\circ} 18.67^{\prime} \mathrm{W}$ & $\mathrm{C}$ & Sig & 12 & $\begin{array}{l}\text { López et al. } \\
\text { (in press) }\end{array}$ & \\
\hline 25 Feb 2007 & $\begin{array}{c}\text { Costa Norte, } \\
\text { Matanzas }\end{array}$ & $23^{\circ} 10.68^{\prime} \mathrm{N}, 81^{\circ} 70.27^{\prime} \mathrm{W}$ & $\mathrm{C}$ & Sig & 1 & $\begin{array}{l}\text { López et al. } \\
\text { (in press) }\end{array}$ & \\
\hline 25 Feb 2007 & $\begin{array}{c}\text { Costa Norte, } \\
\text { Matanzas }\end{array}$ & $23^{\circ} 11.40^{\prime} \mathrm{N}, 81^{\circ} 10.60^{\prime} \mathrm{W}$ & $\mathrm{C}$ & Sig & 4 & $\begin{array}{l}\text { López et al. } \\
\text { (in press) }\end{array}$ & \\
\hline 1 Mar 2007 & $\begin{array}{c}\text { Costa Norte, } \\
\text { Matanzas }\end{array}$ & $23^{\circ} 11.78^{\prime} \mathrm{N}, 81^{\circ} 40.63^{\prime} \mathrm{W}$ & $\mathrm{C}$ & Sig & 3 & $\begin{array}{l}\text { López et al. } \\
\text { (in press) }\end{array}$ & \\
\hline 3 Feb 2008 & $\begin{array}{c}\text { Costa Norte, } \\
\text { Matanzas }\end{array}$ & $23^{\circ} 09.63^{\prime} \mathrm{N}, 81^{\circ} 15.03^{\prime} \mathrm{W}$ & $\mathrm{C}$ & Sig & 15 & $\begin{array}{l}\text { López et al. } \\
\text { (in press) }\end{array}$ & \\
\hline 3 Feb 2008 & $\begin{array}{c}\text { Costa Norte, } \\
\text { Matanzas }\end{array}$ & $23^{\circ} 12.43^{\prime} \mathrm{N}, 81^{\circ} 50.60^{\prime} \mathrm{W}$ & $\mathrm{C}$ & Sig & 6 & $\begin{array}{l}\text { López et al. } \\
\text { (in press) }\end{array}$ & \\
\hline 6 Feb 2008 & $\begin{array}{c}\text { Costa Norte, } \\
\text { Matanzas }\end{array}$ & $23^{\circ} 12.72^{\prime} \mathrm{N}, 81^{\circ} 90.70^{\prime} \mathrm{W}$ & $\mathrm{C}$ & Sig & 20 & $\begin{array}{l}\text { López et al. } \\
\text { (in press) }\end{array}$ & \\
\hline 30 Mar 2008 & $\begin{array}{c}\text { Costa Norte, } \\
\text { Matanzas }\end{array}$ & $23^{\circ} 09.23^{\prime} \mathrm{N}, 81^{\circ} 16.17^{\prime} \mathrm{W}$ & $\mathrm{C}$ & Sig & 4 & $\begin{array}{l}\text { López et al. } \\
\text { (in press) }\end{array}$ & \\
\hline 2 Apr 2008 & $\begin{array}{c}\text { Costa Norte, } \\
\text { Matanzas }\end{array}$ & $23^{\circ} 09.28^{\prime} \mathrm{N}, 81^{\circ} 15.87^{\prime} \mathrm{W}$ & $\mathrm{C}$ & Sig & 7 & $\begin{array}{l}\text { López et al. } \\
\text { (in press) }\end{array}$ & \\
\hline 2 Apr 2008 & $\begin{array}{c}\text { Costa Norte, } \\
\text { Matanzas }\end{array}$ & $23^{\circ} 08.23^{\prime} \mathrm{N}, 81^{\circ} 18.45^{\prime} \mathrm{W}$ & $\mathrm{C}$ & Sig & 2 & $\begin{array}{l}\text { López et al. } \\
\text { (in press) }\end{array}$ & \\
\hline 29 Jun 2008 & $\begin{array}{c}\text { Bahía de Cárdenas, } \\
\text { Matanzas }\end{array}$ & $23^{\circ} 09.20^{\prime} \mathrm{N}, 81^{\circ} 80.38^{\prime} \mathrm{W}$ & $\mathrm{C}$ & Sig & 4 & $\begin{array}{l}\text { López et al. } \\
\text { (in press) }\end{array}$ & \\
\hline 29 Jun 2008 & $\begin{array}{c}\text { Bahía de Cárdenas, } \\
\text { Matanzas }\end{array}$ & $23^{\circ} 09.35^{\prime} \mathrm{N}, 81^{\circ} 80.72^{\prime} \mathrm{W}$ & $\mathrm{C}$ & Sig & 15 & $\begin{array}{l}\text { López et al. } \\
\text { (in press) }\end{array}$ & \\
\hline 30 Jun 2008 & $\begin{array}{l}\text { Costa Norte, } \\
\text { Matanzas }\end{array}$ & $23^{\circ} 12.65^{\prime} \mathrm{N}, 81^{\circ} 60.20^{\prime} \mathrm{W}$ & $\mathrm{C}$ & Sig & 6 & $\begin{array}{l}\text { López et al. } \\
\text { (in press) }\end{array}$ & \\
\hline
\end{tabular}




\begin{tabular}{|c|c|c|c|c|c|c|c|}
\hline Species/Date & Location & Position & Status $^{\mathrm{a}}$ & Type $^{\mathrm{b}}$ & $\begin{array}{l}\text { Group } \\
\text { Size }\end{array}$ & Source $^{c}$ & Comments \\
\hline 30 Jun 2008 & $\begin{array}{l}\text { Costa Norte, } \\
\text { Matanzas }\end{array}$ & $23^{\circ} 13.42^{\prime} \mathrm{N}, 81^{\circ} 50.65^{\prime} \mathrm{W}$ & C & Sig & 17 & $\begin{array}{l}\text { López et al. } \\
\text { (in press) }\end{array}$ & \\
\hline 30 Jun 2008 & $\begin{array}{l}\text { Costa Norte, } \\
\text { Matanzas }\end{array}$ & $23^{\circ} 12.98^{\prime} \mathrm{N}, 81^{\circ} 80.43^{\prime} \mathrm{W}$ & C & Sig & 1 & $\begin{array}{l}\text { López et al. } \\
\text { (in press) }\end{array}$ & \\
\hline $1 \mathrm{Jul} 2008$ & $\begin{array}{l}\text { Costa Norte, } \\
\text { Matanzas }\end{array}$ & $23^{\circ} 08.60^{\prime} \mathrm{N}, 81^{\circ} 17.15^{\prime} \mathrm{W}$ & $\mathrm{C}$ & Sig & 5 & $\begin{array}{l}\text { López et al. } \\
\text { (in press) }\end{array}$ & \\
\hline $1 \mathrm{Jul} 2008$ & $\begin{array}{c}\text { Costa Norte, } \\
\text { Matanzas }\end{array}$ & $23^{\circ} 13.10^{\prime} \mathrm{N}, 81^{\circ} 60.17^{\prime} \mathrm{W}$ & $\mathrm{C}$ & Sig & 1 & $\begin{array}{l}\text { López et al. } \\
\text { (in press) }\end{array}$ & \\
\hline $1 \mathrm{Jul} 2008$ & $\begin{array}{c}\text { Bahía de Cárdenas, } \\
\text { Matanzas }\end{array}$ & $23^{\circ} 07.13^{\prime} \mathrm{N}, 81^{\circ} 80.95^{\prime} \mathrm{W}$ & $\mathrm{C}$ & Sig & 6 & $\begin{array}{l}\text { López et al. } \\
\text { (in press) }\end{array}$ & \\
\hline $1 \mathrm{Jul} 2008$ & $\begin{array}{c}\text { Costa Norte, } \\
\text { Matanzas }\end{array}$ & $23^{\circ} 11.65^{\prime} \mathrm{N}, 81^{\circ} 50.82^{\prime} \mathrm{W}$ & $\mathrm{C}$ & Sig & 1 & $\begin{array}{l}\text { López et al. } \\
\text { (in press) }\end{array}$ & \\
\hline $1 \mathrm{Jul} 2008$ & $\begin{array}{c}\text { Costa Norte, } \\
\text { Matanzas }\end{array}$ & $23^{\circ} 11.83^{\prime} \mathrm{N}, 81^{\circ} 50.85^{\prime} \mathrm{W}$ & $\mathrm{C}$ & Sig & 5 & $\begin{array}{l}\text { López et al. } \\
\text { (in press) }\end{array}$ & \\
\hline $2 \mathrm{Jul} 2008$ & $\begin{array}{c}\text { Bahía de Cárdenas, } \\
\text { Matanzas }\end{array}$ & $23^{\circ} 04.90^{\prime} \mathrm{N}, 81^{\circ} 10.83^{\prime} \mathrm{W}$ & C & Sig & 7 & $\begin{array}{l}\text { López et al. } \\
\text { (in press) }\end{array}$ & \\
\hline 2 Jul 2008 & $\begin{array}{c}\text { Bahía de Cárdenas, } \\
\text { Matanzas }\end{array}$ & $23^{\circ} 08.57^{\prime} \mathrm{N}, 81^{\circ} 13.32^{\prime} \mathrm{W}$ & C & Sig & 8 & $\begin{array}{l}\text { López et al. } \\
\text { (in press) }\end{array}$ & \\
\hline $2 \mathrm{Jul} 2008$ & $\begin{array}{c}\text { Bahía de Cárdenas, } \\
\text { Matanzas }\end{array}$ & $23^{\circ} 09.55^{\prime} \mathrm{N}, 81^{\circ} 10.83^{\prime} \mathrm{W}$ & $\mathrm{C}$ & Sig & 5 & $\begin{array}{l}\text { López et al. } \\
\text { (in press) }\end{array}$ & \\
\hline 3 Jul 2008 & $\begin{array}{c}\text { Bahía de Cárdenas, } \\
\text { Matanzas }\end{array}$ & $23^{\circ} 10.35^{\prime} \mathrm{N}, 81^{\circ} 60.75^{\prime} \mathrm{W}$ & $\mathrm{C}$ & Sig & 10 & $\begin{array}{l}\text { López et al. } \\
\text { (in press) }\end{array}$ & \\
\hline 3 Jul 2008 & $\begin{array}{c}\text { Costa Norte, } \\
\text { Matanzas }\end{array}$ & $23^{\circ} 09.52^{\prime} \mathrm{N}, 81^{\circ} 15.78^{\prime} \mathrm{W}$ & $\mathrm{C}$ & Sig & 2 & $\begin{array}{l}\text { López et al. } \\
\text { (in press) }\end{array}$ & \\
\hline 3 Jul 2008 & $\begin{array}{l}\text { Costa Norte, } \\
\text { Matanzas }\end{array}$ & $23^{\circ} 08.13^{\prime} \mathrm{N}, 81^{\circ} 18.70^{\prime} \mathrm{W}$ & $\mathrm{C}$ & Sig & 1 & $\begin{array}{l}\text { López et al. } \\
\text { (in press) }\end{array}$ & \\
\hline 26 Aug 2008 & $\begin{array}{l}\text { Costa Norte, } \\
\text { Matanzas }\end{array}$ & $23^{\circ} 08.75^{\prime} \mathrm{N}, 81^{\circ} 16.73^{\prime} \mathrm{W}$ & $\mathrm{C}$ & Sig & 2 & $\begin{array}{l}\text { López et al. } \\
\text { (in press) }\end{array}$ & \\
\hline 26 Aug 2008 & $\begin{array}{l}\text { Costa Norte, } \\
\text { Matanzas }\end{array}$ & $23^{\circ} 11.10^{\prime} \mathrm{N}, 81^{\circ} 12.75^{\prime} \mathrm{W}$ & $\mathrm{C}$ & Sig & 2 & $\begin{array}{l}\text { López et al. } \\
\text { (in press) }\end{array}$ & \\
\hline 26 Aug 2008 & $\begin{array}{l}\text { Costa Norte, } \\
\text { Matanzas }\end{array}$ & $23^{\circ} 12.00^{\prime} \mathrm{N}, 81^{\circ} 11.18^{\prime} \mathrm{W}$ & $\mathrm{C}$ & Sig & 2 & $\begin{array}{l}\text { López et al. } \\
\text { (in press) }\end{array}$ & \\
\hline 26 Aug 2008 & $\begin{array}{l}\text { Costa Norte, } \\
\text { Matanzas }\end{array}$ & $23^{\circ} 13.35^{\prime} \mathrm{N}, 81^{\circ} 80.52^{\prime} \mathrm{W}$ & C & Sig & 1 & $\begin{array}{l}\text { López et al. } \\
\text { (in press) }\end{array}$ & \\
\hline 26 Aug 2008 & $\begin{array}{l}\text { Costa Norte, } \\
\text { Matanzas }\end{array}$ & $23^{\circ} 13.48^{\prime} \mathrm{N}, 81^{\circ} 80.00^{\prime} \mathrm{W}$ & $\mathrm{C}$ & Sig & 18 & $\begin{array}{l}\text { López et al. } \\
\text { (in press) }\end{array}$ & \\
\hline 26 Aug 2008 & $\begin{array}{l}\text { Costa Norte, } \\
\text { Matanzas }\end{array}$ & $23^{\circ} 13.52^{\prime} \mathrm{N}, 81^{\circ} 70.13^{\prime} \mathrm{W}$ & $\mathrm{C}$ & Sig & 9 & $\begin{array}{l}\text { López et al. } \\
\text { (in press) }\end{array}$ & \\
\hline 26 Aug 2008 & $\begin{array}{l}\text { Costa Norte, } \\
\text { Matanzas }\end{array}$ & $23^{\circ} 13.07^{\prime} \mathrm{N}, 81^{\circ} 50.72^{\prime} \mathrm{W}$ & $\mathrm{C}$ & Sig & 13 & $\begin{array}{l}\text { López et al. } \\
\text { (in press) }\end{array}$ & \\
\hline 26 Aug 2008 & $\begin{array}{l}\text { Costa Norte, } \\
\text { Matanzas }\end{array}$ & $23^{\circ} 13.17^{\prime} \mathrm{N}, 81^{\circ} 50.42^{\prime} \mathrm{W}$ & $\mathrm{C}$ & Sig & 8 & $\begin{array}{l}\text { López et al. } \\
\text { (in press) }\end{array}$ & \\
\hline 26 Aug 2008 & $\begin{array}{l}\text { Costa Norte, } \\
\text { Matanzas }\end{array}$ & $23^{\circ} 12.97^{\prime} \mathrm{N}, 81^{\circ} 50.13^{\prime} \mathrm{W}$ & $\mathrm{C}$ & Sig & 3 & $\begin{array}{l}\text { López et al. } \\
\text { (in press) }\end{array}$ & \\
\hline 27 Aug 2008 & $\begin{array}{l}\text { Costa Norte, } \\
\text { Matanzas }\end{array}$ & $23^{\circ} 08.93^{\prime} \mathrm{N}, 81^{\circ} 17.00^{\prime} \mathrm{W}$ & $\mathrm{C}$ & Sig & 5 & $\begin{array}{l}\text { López et al. } \\
\text { (in press) }\end{array}$ & \\
\hline 27 Aug 2008 & $\begin{array}{l}\text { Costa Norte, } \\
\text { Matanzas }\end{array}$ & $23^{\circ} 08.15^{\prime} \mathrm{N}, 81^{\circ} 16.77^{\prime} \mathrm{W}$ & $\mathrm{C}$ & Sig & 3 & $\begin{array}{l}\text { López et al. } \\
\text { (in press) }\end{array}$ & \\
\hline 28 Aug 2008 & $\begin{array}{l}\text { Costa Norte, } \\
\text { Matanzas }\end{array}$ & $23^{\circ} 08.55^{\prime} \mathrm{N}, 81^{\circ} 17.55^{\prime} \mathrm{W}$ & $\mathrm{C}$ & Sig & 4 & $\begin{array}{l}\text { López et al. } \\
\text { (in press) }\end{array}$ & \\
\hline 29 Aug 2008 & $\begin{array}{l}\text { Costa Norte, } \\
\text { Matanzas }\end{array}$ & $23^{\circ} 09.32^{\prime} \mathrm{N}, 81^{\circ} 15.72^{\prime} \mathrm{W}$ & $\mathrm{C}$ & Sig & 2 & $\begin{array}{l}\text { López et al. } \\
\text { (in press) }\end{array}$ & \\
\hline 12 Oct 2008 & $\begin{array}{c}\text { Costa Norte, } \\
\text { Matanzas }\end{array}$ & $23^{\circ} 12.92^{\prime} \mathrm{N}, 81^{\circ} 40.52^{\prime} \mathrm{W}$ & $\mathrm{C}$ & Sig & 18 & $\begin{array}{l}\text { López et al. } \\
\text { (in press) }\end{array}$ & \\
\hline 13 Oct 2008 & $\begin{array}{c}\text { Bahía de Cárdenas, } \\
\text { Matanzas }\end{array}$ & $23^{\circ} 09.35^{\prime} \mathrm{N}, 81^{\circ} 11.25^{\prime} \mathrm{W}$ & $\mathrm{C}$ & Sig & 7 & $\begin{array}{l}\text { López et al. } \\
\text { (in press) }\end{array}$ & \\
\hline 14 Oct 2008 & $\begin{array}{c}\text { Costa Norte, } \\
\text { Matanzas }\end{array}$ & $23^{\circ} 14.03^{\prime} \mathrm{N}, 81^{\circ} 50.03^{\prime} \mathrm{W}$ & $\mathrm{C}$ & Sig & 3 & $\begin{array}{l}\text { López et al. } \\
\text { (in press) }\end{array}$ & \\
\hline \multicolumn{8}{|c|}{ Stenella attenuata } \\
\hline Jul 1954 & Habana & $\left(23^{\circ} 11^{\prime} \mathrm{N}, 82^{\circ} 24^{\prime} \mathrm{W}\right)$ & $\mathrm{D}$ & Str & 1 & $\begin{array}{l}\text { Blanco Domínguez } \\
\text { (2011) }\end{array}$ & \\
\hline 18 Sept 1985 & $\begin{array}{l}168 \mathrm{~km} \text { south of } \\
\text { Cabo Corrientes }\end{array}$ & $20^{\circ} 14^{\prime} \mathrm{N}, 84^{\circ} 35^{\prime} \mathrm{W}$ & $\mathrm{C}$ & Sig & 5 & $\begin{array}{l}\text { Perrin } \text { et al. }(1987) ; \\
\text { Mignucci-Giannoni } \\
\text { et al. }(2003)\end{array}$ & \\
\hline 18 Sept 1985 & $\begin{array}{l}183 \mathrm{~km} \text { south of } \\
\text { Cabo Corrientes }\end{array}$ & $20^{\circ} 06^{\prime} \mathrm{N}, 84^{\circ} 29^{\prime} \mathrm{W}$ & $\mathrm{C}$ & Sig & 25 & $\begin{array}{l}\text { Perrin et al. (1987); } \\
\text { Mignucci-Giannoni } \\
\text { et al. } \text { (2003) }\end{array}$ & \\
\hline
\end{tabular}




\begin{tabular}{|c|c|c|c|c|c|c|c|}
\hline Species/Date & Location & Position & Status $^{a}$ & Type $^{b}$ & $\begin{array}{l}\text { Group } \\
\text { Size }\end{array}$ & Source $^{c}$ & Comments \\
\hline 3 Oct 1984 & $\begin{array}{c}52 \mathrm{~km} \text { northwest of } \\
\text { Cayo Jutías }\end{array}$ & $23^{\circ} 00^{\prime} \mathrm{N}, 84^{\circ} 28^{\prime} \mathrm{W}$ & $\mathrm{C}$ & Sig & $12-25$ & $\begin{array}{l}\text { Perrin et al. (1987); } \\
\text { Mignucci-Giannoni } \\
\quad \text { et al. }(2003)\end{array}$ & \\
\hline 3 Apr 1998 & Off western Cuba & $21^{\circ} 32.22^{\prime} \mathrm{N}, 85^{\circ} 14.93^{\prime} \mathrm{W}$ & $\mathrm{C}$ & Sig & 26 & $\begin{array}{c}\text { Ortega-Ortiz } \\
(2002)\end{array}$ & \\
\hline 4 Apr 1998 & Off western Cuba & $21^{\circ} 37.78^{\prime} \mathrm{N}, 85^{\circ} 37.43^{\prime} \mathrm{W}$ & $\mathrm{C}$ & Sig & 34 & $\begin{array}{l}\text { Ortega-Ortiz } \\
\quad(2002)\end{array}$ & \\
\hline Jun 2006 & $\begin{array}{c}\text { Off Cayo Francés, } \\
\text { Villa Clara }\end{array}$ & $22^{\circ} 32^{\prime} \mathrm{N}, 79^{\circ} 20^{\prime} \mathrm{W}$ & $\mathrm{D}$ & Sig & 50 & Echemendía $^{x}$ & \\
\hline \multicolumn{8}{|c|}{ Stenella frontalis } \\
\hline 1911 & Habana & $\left(23^{\circ} 11^{\prime} \mathrm{N}, 82^{\circ} 24^{\prime} \mathrm{W}\right)$ & $\mathrm{D}$ & Str & 1 & Varona (1980) & \\
\hline 1967 & Habana & $\left(23^{\circ} 11^{\prime} \mathrm{N}, 82^{\circ} 24^{\prime} \mathrm{W}\right)$ & $\mathrm{C}$ & Str & 1 & Varona (1980) & \\
\hline 1991 & $\begin{array}{c}\text { Canal Varadero, } \\
\text { Matanzas }\end{array}$ & $23^{\circ} 12.00^{\prime} \mathrm{N}, 81^{\circ} 6.34^{\prime} \mathrm{W}$ & $\mathrm{C}$ & Sig & 2 & $\begin{array}{c}\text { Guevara, C. and } \\
\text { Blanco, M., pers. } \\
\text { obs. }\end{array}$ & \\
\hline 1994 & Off Pinar del Río & $\left(22^{\circ} 24^{\prime} \mathrm{N}, 84^{\circ} 49^{\prime} \mathrm{W}\right)$ & $\mathrm{C}$ & Sig & 2 & Guevara $^{y}$ & \\
\hline Oct 2004 & $\begin{array}{l}\text { Canal Varadero, } \\
\text { Matanzas }\end{array}$ & $23^{\circ} 12.05^{\prime} \mathrm{N}, 81^{\circ} 06.34^{\prime} \mathrm{W}$ & $\mathrm{C}$ & Sig & 2 & $\begin{array}{c}\text { Guevara, C. and } \\
\text { Blanco, M., pers. } \\
\text { obs. }\end{array}$ & \\
\hline Nov 2004 & $\begin{array}{c}\text { Off Guanabo, } \\
\text { Habana }\end{array}$ & $23^{\circ} 12^{\prime} \mathrm{N}, 82^{\circ} 07^{\prime} \mathrm{W}$ & $\mathrm{P}$ & Sig & 100 & Martínez ${ }^{2}$ & \\
\hline Sept 2005 & Off Tarará, Habana & $23^{\circ} 12^{\prime} \mathrm{N}, 82^{\circ} 14^{\prime} \mathrm{W}$ & $\mathrm{P}$ & Sig & 100 & Martínez $^{2}$ & \\
\hline Apr 2006 & $\begin{array}{c}\text { Off Cayo Santa } \\
\text { María, Caibarién, } \\
\text { Villa Clara }\end{array}$ & $22^{\circ} 42^{\prime} \mathrm{N}, 78^{\circ} 50^{\prime} \mathrm{W}$ & $\mathrm{C}$ & Sig & 100 & $\mathrm{Isla}^{\mathrm{al}}$ & \\
\hline Jan 2008 & $\begin{array}{l}\text { Off Cayo Francés, } \\
\text { Caibarién, Villa } \\
\text { Clara }\end{array}$ & $22^{\circ} 31^{\prime} \mathrm{N}, 79^{\circ} 22^{\prime} \mathrm{W}$ & $\mathrm{C}$ & Sig & 2 & $\mathrm{Isla}^{\mathrm{al}}$ & \\
\hline Feb 2008 & $\begin{array}{l}\text { Off Varadero, } \\
\text { Matanzas }\end{array}$ & $23^{\circ} 12.71^{\prime} \mathrm{N}, 81^{\circ} 03.52^{\prime} \mathrm{W}$ & $\mathrm{C}$ & Sig & 2 & Rivera $^{\text {bl }}$ & \\
\hline Mar 2008 & $\begin{array}{l}\text { Off Varadero, } \\
\text { Matanzas }\end{array}$ & $23^{\circ} 11.33^{\prime} \mathrm{N}, 81^{\circ} 03.52^{\prime} \mathrm{W}$ & $\mathrm{C}$ & Sig & 8 & $\begin{array}{c}\text { López, R., López, } \\
\text { N., and Blanco, M., } \\
\text { pers. obs. }\end{array}$ & \\
\hline Aug 2008 & $\begin{array}{l}\text { Off Varadero, } \\
\text { Matanzas }\end{array}$ & $23^{\circ} 13.57^{\prime} \mathrm{N}, 81^{\circ} 06.13^{\prime} \mathrm{W}$ & $\mathrm{C}$ & Sig & 4 & $\begin{array}{c}\text { López, R., López, } \\
\text { N., and Blanco, M., } \\
\text { pers. obs. }\end{array}$ & \\
\hline \multicolumn{8}{|c|}{ S. attenuata/S. frontalis } \\
\hline 24 Jul 1987 & Off western Cuba & $22^{\circ} 25^{\prime} \mathrm{N}, 85^{\circ} 11^{\prime} \mathrm{W}$ & C & Sig & 15 & $\begin{array}{l}\text { Hal Whitehead } \\
\text { unpub. data }\end{array}$ & \\
\hline 8 Jun 1992 & Off western Cuba & $22^{\circ} 31^{\prime} \mathrm{N}, 84^{\circ} 44^{\prime} \mathrm{W}$ & $\mathrm{C}$ & Sig & 20 & $\begin{array}{l}\text { Hal Whitehead } \\
\text { unpub. data }\end{array}$ & \\
\hline 9 Jun 1992 & Off western Cuba & $21^{\circ} 40^{\prime} \mathrm{N}, 84^{\circ} 58^{\prime} \mathrm{W}$ & $\mathrm{C}$ & Sig & 10 & $\begin{array}{l}\text { Hal Whitehead } \\
\text { unpub. data }\end{array}$ & \\
\hline \multicolumn{8}{|c|}{ Stenella longirostris } \\
\hline 16 Nov 1960 & $\begin{array}{l}\text { Jaimanitas Beach } \\
\text { (west of Habana) }\end{array}$ & $22^{\circ} 48^{\prime} \mathrm{N}, 83^{\circ} 30^{\prime} \mathrm{W}$ & $\mathrm{C}$ & Cap & 1 & Perrin et al. (1981) & \\
\hline Mar 1989 & $\begin{array}{l}\text { Bahía Cabańa, } \\
\text { Santiago de Cuba }\end{array}$ & $\left(22^{\circ} 58.87^{\prime} \mathrm{N}, 82^{\circ} 57.25^{\prime} \mathrm{W}\right)$ & $\mathrm{D}$ & Str & 1 & Soberat $^{\mathrm{n}}$ & $1.81 \mathrm{~m}$ long \\
\hline 8 Jun 2003 & $\begin{array}{l}\text { Straits of Florida; } \\
\text { offshore of Habana }\end{array}$ & $23^{\circ} 52^{\prime} \mathrm{N}, 82^{\circ} 22^{\prime} \mathrm{W}$ & $\mathrm{C}$ & Cap & 1 & $\begin{array}{c}\text { NMFS-SEFSC } \\
(2004)\end{array}$ & \\
\hline 9 Jun 2003 & $\begin{array}{l}\text { Straits of Florida; } \\
\text { offshore of Habana }\end{array}$ & $23^{\circ} 35^{\prime} \mathrm{N}, 82^{\circ} 11^{\prime} \mathrm{W}$ & $\mathrm{C}$ & Cap & 1 & $\begin{array}{c}\text { NMFS-SEFSC } \\
(2004)\end{array}$ & \\
\hline \multicolumn{8}{|l|}{ Stenella spp. } \\
\hline 3 Apr 1998 & Off western Cuba & $21^{\circ} 30.11^{\prime} \mathrm{N}, 85^{\circ} 16.61^{\prime} \mathrm{W}$ & $\mathrm{C}$ & Sig & 4 & $\begin{array}{l}\text { Ortega-Ortiz } \\
\quad(2002)\end{array}$ & \\
\hline \multicolumn{8}{|c|}{ Grampus griseus } \\
\hline $\begin{array}{c}\text { ca. } 12 \text { Dec } \\
1967\end{array}$ & $\begin{array}{c}\text { Straits of Florida (50 } \\
\text { miles west of Cay Sal } \\
\text { Bank) }\end{array}$ & $23^{\circ} 40^{\prime} \mathrm{N}, 81^{\circ} 10^{\prime} \mathrm{W}$ & $\mathrm{C}$ & Sig & ca. 20 & $\begin{array}{c}\text { Caldwell and } \\
\text { Caldwell (1977) }\end{array}$ & \\
\hline 31 Oct 1971 & Near Maceo Park & N/A & $\mathrm{D}$ & Sig & 1 & $\begin{array}{l}\text { de la Osa and } \\
\text { Guma }(1971)^{\mathrm{cl}}\end{array}$ & \\
\hline 31 Oct 1971 & $\begin{array}{c}\text { Mouth of } \\
\text { Almendares River }\end{array}$ & $\left(23^{\circ} 9.07^{\prime} \mathrm{N}, 82^{\circ} 21.61^{\prime} \mathrm{W}\right)$ & $\mathrm{D}$ & Sig & 1 & $\begin{array}{l}\text { de la Osa and } \\
\text { Guma }(1971)^{\mathrm{cl}}\end{array}$ & \\
\hline 31 Oct 1971 & $\begin{array}{l}\text { Off Santa María del } \\
\text { Mar Beach, Habana }\end{array}$ & $\left(23^{\circ} 12.76^{\prime} \mathrm{N}, 82^{\circ} 13.98^{\prime} \mathrm{W}\right)$ & $\mathrm{D}$ & Sig & $>1$ & $\begin{array}{l}\text { de la Osa and } \\
\text { Guma }(1971)^{\mathrm{cl}}\end{array}$ & \\
\hline Aug 1972 & Bahía de Matanzas & $\left(23^{\circ} 04.33^{\prime} \mathrm{N}, 81^{\circ} 29.03^{\prime} \mathrm{W}\right)$ & $\mathrm{C}$ & Str & 1 & Varona (1980) & \\
\hline
\end{tabular}




\begin{tabular}{|c|c|c|c|c|c|c|c|}
\hline Species/Date & Location & Position & Status $^{\mathrm{a}}$ & Type $^{b}$ & $\begin{array}{l}\text { Group } \\
\text { Size }\end{array}$ & Source $^{c}$ & Comments \\
\hline Oct 1981 & $\begin{array}{l}\text { Playa Santa María } \\
\text { del Mar, Habana }\end{array}$ & $\left(23^{\circ} 10.59^{\prime} \mathrm{N}, 82^{\circ} 11.02^{\prime} \mathrm{W}\right)$ & $\mathrm{C}$ & Str & 1 & Varona (1980) & \\
\hline Sept 1997 & $\begin{array}{l}\text { Cayo Cobo, } \\
\text { Caibarién, Villa } \\
\text { Clara }\end{array}$ & $\left(22^{\circ} 08.89^{\prime} \mathrm{N}, 81^{\circ} 27.91^{\prime} \mathrm{W}\right)$ & $\mathrm{C}$ & Str & 4 & Sánchez $^{\mathrm{d} 1}$ & $\begin{array}{c}2.85,2.7,2.65 \text {, and } 2.68 \mathrm{~m} \\
\text { long }\end{array}$ \\
\hline \multicolumn{8}{|c|}{ Pseudorca crassidens } \\
\hline 3 Jul 1858 & Near Habana & $\left(23^{\circ} 10.34^{\prime} \mathrm{N}, 82^{\circ} 21.50^{\prime} \mathrm{W}\right)$ & $\mathrm{D}$ & Cap & 1 & Cuní (1918) & $\begin{array}{c}3 \mathrm{~m} \text { long; said to be kept at the } \\
\text { Academia de Ciencias Médicas, } \\
\text { Físicas y Naturales, Habana }\end{array}$ \\
\hline 1886 & Cojímar, Habana & $\left(23^{\circ} 10^{\prime} \mathrm{N}, 82^{\circ} 18^{\prime} \mathrm{W}\right)$ & $\mathrm{D}$ & Str & 1 & $\begin{array}{l}\text { de la Torre (1887); } \\
\text { Cuní (1918) }\end{array}$ & $\begin{array}{c}\text { Skeleton said to be in the } \\
\text { Academia de Ciencias }\end{array}$ \\
\hline Jul 1972 & Guanabo, Habana & $\left(23^{\circ} 10.38^{\prime} \mathrm{N}, 82^{\circ} 07.09^{\prime} \mathrm{W}\right)$ & $\mathrm{C}$ & Str & 1 & Varona (1980) & $3.6 \mathrm{~m}$ long \\
\hline 1973 & Holguín & $\left(20^{\circ} 46.79^{\prime} \mathrm{N}, 75^{\circ} 46.33^{\prime} \mathrm{W}\right)$ & $\mathrm{C}$ & Str & 1 & Varona (1980) & $4.1 \mathrm{~m}$ long \\
\hline Mar 1973 & $\begin{array}{c}\text { Playa Justicí, } \\
\text { Santiago de Cuba }\end{array}$ & $\left(19^{\circ} 57.02^{\prime} \mathrm{N}, 75^{\circ} 44.28^{\prime} \mathrm{W}\right)$ & $\mathrm{C}$ & Str & 1 & Soberat $^{\mathrm{n}}$ & $1.03 \mathrm{~m}$ long \\
\hline Dec 1981 & $\begin{array}{l}\text { Playa Marianao, } \\
\text { Habana }\end{array}$ & $\left(23^{\circ} 06.12^{\prime} \mathrm{N}, 82^{\circ} 27.14^{\prime} \mathrm{W}\right)$ & $\mathrm{C}$ & Str & 1 & Varona (2002) & $2.7 \mathrm{~m}$ long \\
\hline \multicolumn{8}{|l|}{ Orcinus orca } \\
\hline 1983 & $\begin{array}{l}\text { Mariel - Baracoa, } \\
\text { Habana }\end{array}$ & $23^{\circ} 10^{\prime} \mathrm{N}, 82^{\circ} 20^{\prime} \mathrm{W}$ & $\mathrm{C}$ & Sig & 3 & $\begin{array}{l}\text { Guitart, D. and } \\
\text { Blanco, M., pers. } \\
\text { obs. }\end{array}$ & \\
\hline Aug 1984 & Guanabo, Habana & $23^{\circ} 12^{\prime} \mathrm{N}, 82^{\circ} 07^{\prime} \mathrm{W}$ & $\mathrm{C}$ & Sig & 1 & $\begin{array}{l}\text { Guitart, D. and } \\
\text { Blanco, M., pers. } \\
\text { obs. }\end{array}$ & \\
\hline Aug 1994 & Guanabo, Habana & $23^{\circ} 12^{\prime} \mathrm{N}, 82^{\circ} 07^{\prime} \mathrm{W}$ & $\mathrm{C}$ & Sig & 4 & $\begin{array}{l}\text { Guevara, C. and } \\
\text { Blanco, M., pers. } \\
\text { obs. }\end{array}$ & \\
\hline Apr 2004 & $\begin{array}{l}\text { Cayo Cobo, } \\
\text { Caibarién, Villa } \\
\text { Clara }\end{array}$ & $\left(22^{\circ} 08.62^{\prime} \mathrm{N}, 81^{\circ} 28.08^{\prime} \mathrm{W}\right)$ & $\mathrm{C}$ & Str & 1 & $\begin{array}{l}\text { Blanco, M., pers. } \\
\text { obs. }\end{array}$ & $4.65 \mathrm{~m}$ long \\
\hline 2005 & $\begin{array}{l}\text { Cayo Francés, } \\
\text { Caibarién, Villa } \\
\text { Clara }\end{array}$ & $22^{\circ} 33^{\prime} \mathrm{N}, 79^{\circ} 18^{\prime} \mathrm{W}$ & $\mathrm{C}$ & Sig & 4 & Echemendía $^{x}$ & \\
\hline \multicolumn{8}{|c|}{ Globicephala macrorhynchus } \\
\hline 11 Sept 1908 & Bahía de Matanzas & $\left(23^{\circ} 04^{\prime} \mathrm{N}, 81^{\circ} 30^{\prime} \mathrm{W}\right)$ & C & Sig & 3 & $\begin{array}{l}\text { Cuní (1918); } \\
\text { Aguayo (1954) }\end{array}$ & \\
\hline 11 Sept 1908 & $\begin{array}{l}\text { Río Yumurí--near } \\
\text { Bahía de Matanzas }\end{array}$ & $\left(23^{\circ} 3.15^{\prime} \mathrm{N}, 81^{\circ} 32.55^{\prime} \mathrm{W}\right)$ & $\mathrm{C}$ & Cap & 1 & $\begin{array}{l}\text { Cuní (1918); } \\
\text { Aguayo (1954) }\end{array}$ & \\
\hline Jul 1954 & Bahía de Matanzas & N/A & $\mathrm{D}$ & Str & 1 & $\begin{array}{c}\text { Blanco } \\
\text { Domínguez (2011) } \\
\text { (identification by } \\
\text { G. Aguayo) }\end{array}$ & \\
\hline 1964 & $\begin{array}{c}\text { Playa Salado, } \\
\text { Habana }\end{array}$ & $\left(23^{\circ} 07.23^{\prime} \mathrm{N}, 82^{\circ} 25.93^{\prime} \mathrm{W}\right)$ & $\mathrm{C}$ & Str & 1 & Varona (1980) & \\
\hline Nov 1971 & $\begin{array}{l}\text { Río Almendares, } \\
\text { Habana }\end{array}$ & $\left(23^{\circ} 08.12^{\prime} \mathrm{N}, 82^{\circ} 24.51^{\prime} \mathrm{W}\right)$ & $\mathrm{C}$ & Str & 1 & Guitart $^{\mathrm{d}}$ & \\
\hline Oct 1981 & $\begin{array}{l}\text { Playa Santa María } \\
\text { del Mar, Habana }\end{array}$ & $\left(23^{\circ} 10.58^{\prime} \mathrm{N}, 82^{\circ} 11.22^{\prime} \mathrm{W}\right)$ & $\mathrm{C}$ & Str & 1 & Guitart $^{\mathrm{d}}$ & \\
\hline Feb 1986 & $\begin{array}{l}\text { Cayo Saetía, } \\
\text { Holguín }\end{array}$ & $\left(20^{\circ} 46.27^{\prime} \mathrm{N}, 75^{\circ} 29.78^{\prime} \mathrm{W}\right)$ & $\mathrm{C}$ & Str & 14 & Guitart $^{\mathrm{d}}$ & \\
\hline Mar 1986 & Holguín & $\left(20^{\circ} 47.16^{\prime} \mathrm{N}, 75^{\circ} 46.53^{\prime} \mathrm{W}\right)$ & $\mathrm{C}$ & Str & 2 & Guitart $^{\mathrm{d}}$ & \\
\hline Sept 1988 & $\begin{array}{c}\text { Bahía Santiago de } \\
\text { Cuba }\end{array}$ & $\left(19^{\circ} 59.67^{\prime} \mathrm{N}, 75^{\circ} 51.77^{\prime} \mathrm{W}\right)$ & $\mathrm{C}$ & Str & 1 & Soberat $^{\mathrm{n}}$ & $4.13 \mathrm{~m}$ long \\
\hline Nov 1988 & $\begin{array}{c}\text { Playa Larga, } \\
\text { Matanzas }\end{array}$ & $\left(22^{\circ} 16.08^{\prime} \mathrm{N}, 81^{\circ} 12.34^{\prime} \mathrm{W}\right)$ & $\mathrm{C}$ & Str & 2 & $\begin{array}{l}\text { Guitart, D. and } \\
\text { Blanco, M., pers. } \\
\text { obs. }\end{array}$ & 4.46 and $4.31 \mathrm{~m}$ long \\
\hline \multicolumn{8}{|c|}{ Globicephala spp. } \\
\hline 21 Feb 2004 & $\begin{array}{c}\text { Off eastern coast of } \\
\text { Cuba }\end{array}$ & $19^{\circ} 57^{\prime} \mathrm{N}, 73^{\circ} 59^{\prime} \mathrm{W}$ & $\mathrm{C}$ & Cap & 1 & $\begin{array}{l}\text { NMFS-SEFSC } \\
(2004)\end{array}$ & \\
\hline 27 Feb 2004 & $\begin{array}{l}\text { Off eastern coast of } \\
\text { Cuba }\end{array}$ & $19^{\circ} 48^{\prime} \mathrm{N}, 74^{\circ} 05^{\prime} \mathrm{W}$ & $\mathrm{C}$ & Cap & 1 & $\begin{array}{c}\text { NMFS-SEFSC } \\
(2004)\end{array}$ & \\
\hline 18 Sept 2005 & $\begin{array}{l}\text { ca. } 8 \text { miles south of } \\
\text { Guantánamo Bay }\end{array}$ & $\left(19^{\circ} 52.34^{\prime} \mathrm{N}, 75^{\circ} 1.72^{\prime} \mathrm{W}\right)$ & $\mathrm{P}$ & Sig & $>1$ & $\begin{array}{l}\text { GTMO unpub. } \\
\text { data }\end{array}$ & \\
\hline \multicolumn{8}{|c|}{ Unidentified cetacean } \\
\hline 9 Jan 1983 & Off Nuevitas & $21^{\circ} 47^{\prime} \mathrm{N}, 76^{\circ} 51^{\prime} \mathrm{W}$ & $\mathrm{C}$ & Sig & 1 & USNM & \\
\hline
\end{tabular}




\begin{tabular}{|c|c|c|c|c|c|c|c|}
\hline Species/Date & Location & Position & Status $^{\mathrm{a}}$ & Type $^{\text {b }}$ & $\begin{array}{l}\text { Group } \\
\text { Size }\end{array}$ & Source $^{c}$ & Comments \\
\hline \multicolumn{8}{|c|}{ Unidentified dolphin/porpoise } \\
\hline 14 Oct 1975 & $\begin{array}{l}\text { Off southeastern } \\
\text { coast of Cuba }\end{array}$ & $19^{\circ} 39^{\prime} \mathrm{N}, 74^{\circ} 51^{\prime} \mathrm{W}$ & $\mathrm{C}$ & Sig & 8 & CETAP $(1982)^{\mathrm{r}}$ & \\
\hline \multicolumn{8}{|c|}{ Unidentified small dolphin } \\
\hline 4 Apr 1998 & $\begin{array}{c}\text { Off western coast } \\
\text { of Cuba }\end{array}$ & $21^{\circ} 38.15^{\prime} \mathrm{N}, 85^{\circ} 35.33^{\prime} \mathrm{W}$ & $\mathrm{C}$ & Sig & 6 & Ortega-Ortiz (2002) & \\
\hline
\end{tabular}

\begin{tabular}{|c|c|c|c|c|c|c|c|}
\hline \multicolumn{8}{|c|}{ TRICHECHIDAE } \\
\hline \multicolumn{8}{|c|}{ Trichechus manatus } \\
\hline Before 1980 & Puerto Esperanza & $\left(22^{\circ} 46.06^{\prime} \mathrm{N}, 83^{\circ} 47.45^{\prime} \mathrm{W}\right)$ & $\mathrm{C}$ & Sig & N/A & $\begin{array}{c}\text { Estrada and Ferrer } \\
\text { (1987) }\end{array}$ & \\
\hline Before 1980 & Puerto Esperanza & $\left(22^{\circ} 46.06^{\prime} \mathrm{N}, 83^{\circ} 47.91^{\prime} \mathrm{W}\right)$ & $\mathrm{C}$ & Sig & N/A & $\begin{array}{c}\text { Estrada and Ferrer } \\
\text { (1987) }\end{array}$ & \\
\hline Before 1980 & Puerto Esperanza & $\left(22^{\circ} 46.86^{\prime} \mathrm{N}, 83^{\circ} 46.71^{\prime} \mathrm{W}\right)$ & $\mathrm{C}$ & Sig & N/A & $\begin{array}{c}\text { Estrada and Ferrer } \\
(1987)\end{array}$ & \\
\hline Before 1980 & Arroyos de Mantua & $\left(22^{\circ} 21.24^{\prime} \mathrm{N}, 84^{\circ} 23.92^{\prime} \mathrm{W}\right)$ & $\mathrm{C}$ & Sig & N/A & $\begin{array}{l}\text { Estrada and Ferrer } \\
\text { (1987) }\end{array}$ & \\
\hline 1981 & Cortés & $\left(22^{\circ} 3.51^{\prime} \mathrm{N}, 83^{\circ} 59.53^{\prime} \mathrm{W}\right)$ & $\mathrm{C}$ & Sig & N/A & $\begin{array}{c}\text { Estrada and Ferrer } \\
(1987)\end{array}$ & \\
\hline 1981 & Cortés & $\left(22^{\circ} 2.56^{\prime} \mathrm{N}, 83^{\circ} 59.15^{\prime} \mathrm{W}\right)$ & $\mathrm{C}$ & Sig & N/A & $\begin{array}{c}\text { Estrada and Ferrer } \\
(1987)\end{array}$ & \\
\hline 1982 & Arroyos de Mantua & $\left(22^{\circ} 20.75^{\prime} \mathrm{N}, 84^{\circ} 25.08^{\prime} \mathrm{W}\right)$ & $\mathrm{C}$ & Sig & N/A & $\begin{array}{l}\text { Estrada and Ferrer } \\
\qquad(1987)\end{array}$ & \\
\hline 1982 & Cortés & $\left(22^{\circ} 3.49^{\prime} \mathrm{N}, 83^{\circ} 59.05^{\prime} \mathrm{W}\right)$ & $\mathrm{C}$ & Sig & N/A & $\begin{array}{l}\text { Estrada and Ferrer } \\
\qquad(1987)\end{array}$ & \\
\hline 1982 & Puerto Esperanza & $\left(22^{\circ} 46.15^{\prime} \mathrm{N}, 83^{\circ} 47.34^{\prime} \mathrm{W}\right)$ & $\mathrm{C}$ & Sig & N/A & $\begin{array}{l}\text { Estrada and Ferrer } \\
(1987)\end{array}$ & \\
\hline 1983 & Arroyos de Mantua & $\left(22^{\circ} 19.93^{\prime} \mathrm{N}, 84^{\circ} 24.34^{\prime} \mathrm{W}\right)$ & $\mathrm{C}$ & Sig & N/A & $\begin{array}{l}\text { Estrada and Ferrer } \\
\text { (1987) }\end{array}$ & \\
\hline 1983 & Arroyos de Mantua & $\left(22^{\circ} 20.68^{\prime} \mathrm{N}, 84^{\circ} 23.96^{\prime} \mathrm{W}\right)$ & $\mathrm{C}$ & Sig & N/A & $\begin{array}{l}\text { Estrada and Ferrer } \\
\text { (1987) }\end{array}$ & \\
\hline 1983 & Cortés & $\left(22^{\circ} 1.88^{\prime} \mathrm{N}, 83^{\circ} 58.85^{\prime} \mathrm{W}\right)$ & $\mathrm{C}$ & Sig & N/A & $\begin{array}{c}\text { Estrada and Ferrer } \\
\text { (1987) }\end{array}$ & \\
\hline 1983 & Cortés & $\left(22^{\circ} 2.71^{\prime} \mathrm{N}, 83^{\circ} 58.86^{\prime} \mathrm{W}\right)$ & $\mathrm{C}$ & Sig & N/A & $\begin{array}{c}\text { Estrada and Ferrer } \\
(1987)\end{array}$ & \\
\hline 1983 & Cortés & $\left(22^{\circ} 3.01^{\prime} \mathrm{N}, 83^{\circ} 59.72^{\prime} \mathrm{W}\right)$ & $\mathrm{C}$ & Sig & N/A & $\begin{array}{l}\text { Estrada and Ferrer } \\
\text { (1987) }\end{array}$ & \\
\hline 1983 & $\begin{array}{c}\text { Surgidero de } \\
\text { Batabanó }\end{array}$ & $\left(22^{\circ} 40.69^{\prime} \mathrm{N}, 82^{\circ} 18.31^{\prime} \mathrm{W}\right)$ & $\mathrm{C}$ & Sig & N/A & $\begin{array}{c}\text { Estrada and Ferrer } \\
(1987)\end{array}$ & \\
\hline 1983 & $\begin{array}{c}\text { Surgidero de } \\
\text { Batabanó }\end{array}$ & $\left(22^{\circ} 40.80^{\prime} \mathrm{N}, 82^{\circ} 18.41^{\prime} \mathrm{W}\right)$ & $\mathrm{C}$ & Sig & N/A & $\begin{array}{l}\text { Estrada and Ferrer } \\
\qquad(1987)\end{array}$ & \\
\hline 1983 & $\begin{array}{c}\text { Surgidero de } \\
\text { Batabanó }\end{array}$ & $\left(22^{\circ} 40.83^{\prime} \mathrm{N}, 82^{\circ} 17.94^{\prime} \mathrm{W}\right)$ & $\mathrm{C}$ & Sig & N/A & $\begin{array}{l}\text { Estrada and Ferrer } \\
\qquad(1987)\end{array}$ & \\
\hline 1983 & $\begin{array}{l}\text { Surgidero de } \\
\text { Batabanó }\end{array}$ & $\left(22^{\circ} 40.86^{\prime} \mathrm{N}, 82^{\circ} 18.80^{\prime} \mathrm{W}\right)$ & $\mathrm{C}$ & Sig & N/A & $\begin{array}{l}\text { Estrada and Ferrer } \\
\qquad(1987)\end{array}$ & \\
\hline 1984 & Arroyos de Mantua & $\left(22^{\circ} 19.49^{\prime} \mathrm{N}, 84^{\circ} 24.40^{\prime} \mathrm{W}\right)$ & $\mathrm{C}$ & Sig & N/A & $\begin{array}{l}\text { Estrada and Ferrer } \\
(1987)\end{array}$ & \\
\hline 1984 & Cortés & $\left(22^{\circ} 2.08^{\prime} \mathrm{N}, 83^{\circ} 58.38^{\prime} \mathrm{W}\right)$ & $\mathrm{C}$ & Sig & N/A & $\begin{array}{l}\text { Estrada and Ferrer } \\
(1987)\end{array}$ & \\
\hline 1984 & Cortés & $\left(22^{\circ} 2.43^{\prime} \mathrm{N}, 83^{\circ} 59.48^{\prime} \mathrm{W}\right)$ & $\mathrm{C}$ & Sig & N/A & $\begin{array}{c}\text { Estrada and Ferrer } \\
(1987)\end{array}$ & \\
\hline 1984 & Cortés & $\left(22^{\circ} 3.41^{\prime} \mathrm{N}, 83^{\circ} 58.32^{\prime} \mathrm{W}\right)$ & $\mathrm{C}$ & Sig & N/A & $\begin{array}{l}\text { Estrada and Ferrer } \\
\text { (1987) }\end{array}$ & \\
\hline 1984 & Cortés & $\left(22^{\circ} 3.91^{\prime} \mathrm{N}, 83^{\circ} 59.17^{\prime} \mathrm{W}\right)$ & $\mathrm{C}$ & Sig & N/A & $\begin{array}{c}\text { Estrada and Ferrer } \\
(1987)\end{array}$ & \\
\hline 1984 & La Coloma & $\left(22^{\circ} 13.28^{\prime} \mathrm{N}, 83^{\circ} 33.93^{\prime} \mathrm{W}\right)$ & $\mathrm{C}$ & Sig & N/A & $\begin{array}{c}\text { Estrada and Ferrer } \\
(1987)\end{array}$ & \\
\hline 1984 & La Coloma & $\left(22^{\circ} 12.27^{\prime} \mathrm{N}, 83^{\circ} 33.69^{\prime} \mathrm{W}\right)$ & $\mathrm{C}$ & Sig & N/A & $\begin{array}{c}\text { Estrada and Ferrer } \\
(1987)\end{array}$ & \\
\hline 1984 & La Coloma & $\left(22^{\circ} 12.64^{\prime} \mathrm{N}, 83^{\circ} 34.88^{\prime} \mathrm{W}\right)$ & $\mathrm{C}$ & Sig & N/A & $\begin{array}{c}\text { Estrada and Ferrer } \\
(1987)\end{array}$ & \\
\hline 1984 & La Coloma & $\left(22^{\circ} 13.18^{\prime} \mathrm{N}, 83^{\circ} 35.08^{\prime} \mathrm{W}\right)$ & $\mathrm{C}$ & Sig & N/A & $\begin{array}{l}\text { Estrada and Ferrer } \\
(1987)\end{array}$ & \\
\hline 1984 & La Coloma & $\left(22^{\circ} 13.72^{\prime} \mathrm{N}, 83^{\circ} 35.04^{\prime} \mathrm{W}\right)$ & $\mathrm{C}$ & Sig & N/A & $\begin{array}{c}\text { Estrada and Ferrer } \\
\qquad(1987)\end{array}$ & \\
\hline
\end{tabular}




\begin{tabular}{|c|c|c|c|c|c|c|c|}
\hline Species/Date & Location & Position & Status $^{a}$ & Type $^{\mathrm{b}}$ & $\begin{array}{l}\text { Group } \\
\text { Size }\end{array}$ & Source $^{c}$ & Comments \\
\hline 1984 & La Coloma & $\left(22^{\circ} 12.47^{\prime} \mathrm{N}, 83^{\circ} 34.20^{\prime} \mathrm{W}\right)$ & $\mathrm{C}$ & Sig & N/A & $\begin{array}{c}\text { Estrada and Ferrer } \\
\text { (1987) }\end{array}$ & \\
\hline 1984 & La Coloma & $\left(22^{\circ} 13.21^{\prime} \mathrm{N}, 83^{\circ} 34.64^{\prime} \mathrm{W}\right)$ & $\mathrm{C}$ & Sig & N/A & $\begin{array}{l}\text { Estrada and Ferrer } \\
(1987)\end{array}$ & \\
\hline 1984 & La Coloma & $\left(22^{\circ} 12.94^{\prime} \mathrm{N}, 83^{\circ} 35.38^{\prime} \mathrm{W}\right)$ & $\mathrm{C}$ & Sig & N/A & $\begin{array}{l}\text { Estrada and Ferrer } \\
\text { (1987) }\end{array}$ & \\
\hline 1984 & La Coloma & $\left(22^{\circ} 12.81^{\prime} \mathrm{N}, 83^{\circ} 33.96^{\prime} \mathrm{W}\right)$ & $\mathrm{C}$ & Sig & N/A & $\begin{array}{c}\text { Estrada and Ferrer } \\
\text { (1987) }\end{array}$ & \\
\hline 1984 & La Coloma & $\left(22^{\circ} 13.75^{\prime} \mathrm{N}, 83^{\circ} 34.47^{\prime} \mathrm{W}\right)$ & C & Sig & N/A & $\begin{array}{l}\text { Estrada and Ferrer } \\
(1987)\end{array}$ & \\
\hline 1984 & La Coloma & $\left(22^{\circ} 14.12^{\prime} \mathrm{N}, 83^{\circ} 34.57^{\prime} \mathrm{W}\right)$ & $\mathrm{C}$ & Sig & N/A & $\begin{array}{l}\text { Estrada and Ferrer } \\
\text { (1987) }\end{array}$ & \\
\hline 1984 & Puerto Esperanza & $\left(22^{\circ} 46.05^{\prime} \mathrm{N}, 83^{\circ} 47.32^{\prime} \mathrm{W}\right)$ & $\mathrm{C}$ & Sig & N/A & $\begin{array}{c}\text { Estrada and Ferrer } \\
(1987)\end{array}$ & \\
\hline 1984 & Puerto Esperanza & $\left(22^{\circ} 46.09^{\prime} \mathrm{N}, 83^{\circ} 47.53^{\prime} \mathrm{W}\right)$ & C & Sig & N/A & $\begin{array}{c}\text { Estrada and Ferrer } \\
\text { (1987) }\end{array}$ & \\
\hline 1984 & $\begin{array}{l}\text { Surgidero de } \\
\text { Batabanó }\end{array}$ & $\left(22^{\circ} 40.86^{\prime} \mathrm{N}, 82^{\circ} 18.91^{\prime} \mathrm{W}\right)$ & $\mathrm{C}$ & Sig & N/A & $\begin{array}{l}\text { Estrada and Ferrer } \\
\text { (1987) }\end{array}$ & \\
\hline 1984 & $\begin{array}{l}\text { Surgidero de } \\
\text { Batabanó }\end{array}$ & $\left(22^{\circ} 40.80^{\prime} \mathrm{N}, 82^{\circ} 18.13^{\prime} \mathrm{W}\right)$ & $\mathrm{C}$ & Sig & N/A & $\begin{array}{l}\text { Estrada and Ferrer } \\
\text { (1987) }\end{array}$ & \\
\hline 1984 & $\begin{array}{l}\text { Surgidero de } \\
\text { Batabanó }\end{array}$ & $\left(22^{\circ} 40.62^{\prime} \mathrm{N}, 82^{\circ} 18.29^{\prime} \mathrm{W}\right)$ & $\mathrm{C}$ & Sig & N/A & $\begin{array}{l}\text { Estrada and Ferrer } \\
(1987)\end{array}$ & \\
\hline 1984 & $\begin{array}{l}\text { Surgidero de } \\
\text { Batabanó }\end{array}$ & $\left(22^{\circ} 40.69^{\prime} \mathrm{N}, 82^{\circ} 18.10^{\prime} \mathrm{W}\right)$ & $\mathrm{C}$ & Sig & N/A & $\begin{array}{c}\text { Estrada and Ferrer } \\
(1987)\end{array}$ & \\
\hline 1984 & $\begin{array}{l}\text { Surgidero de } \\
\text { Batabanó }\end{array}$ & $\left(22^{\circ} 40.83^{\prime} \mathrm{N}, 82^{\circ} 18.12^{\prime} \mathrm{W}\right)$ & $\mathrm{C}$ & Sig & N/A & $\begin{array}{l}\text { Estrada and Ferrer } \\
\text { (1987) }\end{array}$ & \\
\hline 1984 & $\begin{array}{l}\text { Surgidero de } \\
\text { Batabanó }\end{array}$ & $\left(22^{\circ} 40.67^{\prime} \mathrm{N}, 82^{\circ} 18.41^{\prime} \mathrm{W}\right)$ & $\mathrm{C}$ & Sig & N/A & $\begin{array}{l}\text { Estrada and Ferrer } \\
(1987)\end{array}$ & \\
\hline 1984 & $\begin{array}{l}\text { Surgidero de } \\
\text { Batabanó }\end{array}$ & $\left(22^{\circ} 40.80^{\prime} \mathrm{N}, 82^{\circ} 18.26^{\prime} \mathrm{W}\right)$ & $\mathrm{C}$ & Sig & N/A & $\begin{array}{c}\text { Estrada and Ferrer } \\
\text { (1987) }\end{array}$ & \\
\hline 1984 & $\begin{array}{l}\text { Surgidero de } \\
\text { Batabanó }\end{array}$ & $\left(22^{\circ} 40.81^{\prime} \mathrm{N}, 82^{\circ} 18.15^{\prime} \mathrm{W}\right)$ & $\mathrm{C}$ & Sig & N/A & $\begin{array}{c}\text { Estrada and Ferrer } \\
\text { (1987) }\end{array}$ & \\
\hline 1984 & $\begin{array}{l}\text { Surgidero de } \\
\text { Batabanó }\end{array}$ & $\left(22^{\circ} 40.73^{\prime} \mathrm{N}, 82^{\circ} 18.00^{\prime} \mathrm{W}\right)$ & $\mathrm{C}$ & Sig & N/A & $\begin{array}{l}\text { Estrada and Ferrer } \\
(1987)\end{array}$ & \\
\hline 1984 & $\begin{array}{l}\text { Surgidero de } \\
\text { Batabanó }\end{array}$ & $\left(22^{\circ} 40.66^{\prime} \mathrm{N}, 82^{\circ} 18.20^{\prime} \mathrm{W}\right)$ & $\mathrm{C}$ & Sig & N/A & $\begin{array}{l}\text { Estrada and Ferrer } \\
\text { (1987) }\end{array}$ & \\
\hline 1984 & $\begin{array}{c}\text { Surgidero de } \\
\text { Batabanó }\end{array}$ & $\left(22^{\circ} 40.74^{\prime} \mathrm{N}, 82^{\circ} 18.12^{\prime} \mathrm{W}\right)$ & $\mathrm{C}$ & Sig & N/A & $\begin{array}{l}\text { Estrada and Ferrer } \\
(1987)\end{array}$ & \\
\hline 1985 & Arroyos de Mantua & $\left(22^{\circ} 20.75^{\prime} \mathrm{N}, 84^{\circ} 23.91^{\prime} \mathrm{W}\right)$ & $\mathrm{C}$ & Sig & N/A & $\begin{array}{c}\text { Estrada and Ferrer } \\
\text { (1987) }\end{array}$ & \\
\hline 1985 & Arroyos de Mantua & $\left(22^{\circ} 20.78^{\prime} \mathrm{N}, 84^{\circ} 23.68^{\prime} \mathrm{W}\right)$ & C & Sig & N/A & $\begin{array}{c}\text { Estrada and Ferrer } \\
(1987)\end{array}$ & \\
\hline 1985 & Arroyos de Mantua & $\left(22^{\circ} 20.73^{\prime} \mathrm{N}, 84^{\circ} 23.77^{\prime} \mathrm{W}\right)$ & $\mathrm{C}$ & Sig & N/A & $\begin{array}{c}\text { Estrada and Ferrer } \\
\text { (1987) }\end{array}$ & \\
\hline 1985 & Arroyos de Mantua & $\left(22^{\circ} 20.96^{\prime} \mathrm{N}, 84^{\circ} 23.70^{\prime} \mathrm{W}\right)$ & $\mathrm{C}$ & Sig & N/A & $\begin{array}{c}\text { Estrada and Ferrer } \\
\text { (1987) }\end{array}$ & \\
\hline 1985 & Arroyos de Mantua & $\left(22^{\circ} 20.68^{\prime} \mathrm{N}, 84^{\circ} 23.89^{\prime} \mathrm{W}\right)$ & $\mathrm{C}$ & Sig & N/A & $\begin{array}{c}\text { Estrada and Ferrer } \\
\text { (1987) }\end{array}$ & \\
\hline Jun 1986 & $\begin{array}{l}\text { Mouth of Sagua La } \\
\text { Chica River, Villa } \\
\text { Clara Province }\end{array}$ & $\left(22^{\circ} 56.74^{\prime} \mathrm{N}, 80^{\circ} 0.23^{\prime} \mathrm{W}\right)$ & $\mathrm{C}$ & Sig & 1 & Ortiz et al. (1992) & $\begin{array}{l}\text { Manatee was briefly captured } \\
\text { so researchers could collect a } \\
\text { copepod off its skin }\end{array}$ \\
\hline Before 1988 & $\begin{array}{c}\text { Ensenada de } \\
\text { Caballones, Sancti } \\
\text { Spíritus }\end{array}$ & $\left(21^{\circ} 43.32^{\prime} \mathrm{N}, 79^{\circ} 52.83^{\prime} \mathrm{W}\right)$ & $\mathrm{C}$ & Cap & 1 & Domning (1987) & $\begin{array}{l}\text { Reported by L.T. Ferrer; male; } \\
\qquad 310 \mathrm{~cm} \text { long }\end{array}$ \\
\hline $\begin{array}{l}\text { Between } 18 \\
\text { and } 28 \text { Jul } \\
1996\end{array}$ & $\begin{array}{l}\text { Casa del Mar } \\
\text { Barge, GTMO }\end{array}$ & $\left(19^{\circ} 54.90^{\prime} \mathrm{N}, 75^{\circ} 9.42^{\prime} \mathrm{W}\right)$ & $\mathrm{C}$ & Sig & 1 & $\begin{array}{c}\text { Roca and } \\
\text { Sedaghatkish (1998) }\end{array}$ & \\
\hline $\begin{array}{c}\text { Between } 18 \\
\text { and } 28 \mathrm{Jul} \\
1996\end{array}$ & $\begin{array}{l}\text { Casa del Mar } \\
\text { Barge, GTMO }\end{array}$ & $\left(19^{\circ} 54.90^{\prime} \mathrm{N}, 75^{\circ} 9.42^{\prime} \mathrm{W}\right)$ & $\mathrm{C}$ & Sig & 1 & $\begin{array}{c}\text { Roca and } \\
\text { Sedaghatkish (1998) }\end{array}$ & \\
\hline $\begin{array}{c}\text { Between } 18 \\
\text { and } 28 \mathrm{Jul} \\
1996\end{array}$ & $\begin{array}{l}\text { Casa del Mar } \\
\text { Barge, GTMO }\end{array}$ & $\left(19^{\circ} 54.90^{\prime} \mathrm{N}, 75^{\circ} 9.42^{\prime} \mathrm{W}\right)$ & $\mathrm{C}$ & Sig & 1 & $\begin{array}{c}\text { Roca and } \\
\text { Sedaghatkish (1998) }\end{array}$ & \\
\hline $\begin{array}{c}\text { Between } 18 \\
\text { and } 28 \mathrm{Jul} \\
1996\end{array}$ & $\begin{array}{l}\text { Leeward Pier, } \\
\text { GTMO }\end{array}$ & $\left(19^{\circ} 54.65^{\prime} \mathrm{N}, 75^{\circ} 12.03^{\prime} \mathrm{W}\right)$ & $\mathrm{C}$ & Sig & 1 & $\begin{array}{c}\text { Roca and } \\
\text { Sedaghatkish (1998) }\end{array}$ & \\
\hline
\end{tabular}




\begin{tabular}{|c|c|c|c|c|c|c|c|}
\hline Species/Date & Location & Position & Status $^{a}$ & Type $^{b}$ & $\begin{array}{l}\text { Group } \\
\text { Size }\end{array}$ & Source $^{c}$ & Comments \\
\hline $23 \mathrm{Jul} 1996$ & Deer Point, GTMO & $\left(19^{\circ} 55.42^{\prime} \mathrm{N}, 75^{\circ} 8.70^{\prime} \mathrm{W}\right)$ & C & Sig & 4 & $\begin{array}{c}\text { Roca and } \\
\text { Sedaghatkish (1998) }\end{array}$ & \\
\hline $24 \mathrm{Jul} 1996$ & $\begin{array}{l}\text { Guantánamo River, } \\
\text { GTMO }\end{array}$ & $\left(19^{\circ} 54.75^{\prime} \mathrm{N}, 75^{\circ} 11.72^{\prime} \mathrm{W}\right)$ & $\mathrm{C}$ & Sig & 1 & $\begin{array}{c}\text { Roca and } \\
\text { Sedaghatkish (1998) }\end{array}$ & \\
\hline $24 \mathrm{Jul} 1996$ & $\begin{array}{l}\text { Off Hospital Cay, } \\
\text { GTMO }\end{array}$ & $\left(19^{\circ} 56.77^{\prime} \mathrm{N}, 75^{\circ} 8.67^{\prime} \mathrm{W}\right)$ & $\mathrm{C}$ & Sig & 2 & $\begin{array}{c}\text { Roca and } \\
\text { Sedaghatkish (1998) }\end{array}$ & \\
\hline $25 \mathrm{Jul} 1996$ & $\begin{array}{c}\text { Casa del Mar barge, } \\
\text { GTMO }\end{array}$ & $\left(19^{\circ} 54.90^{\circ} \mathrm{N}, 75^{\circ} 9.42^{\prime} \mathrm{W}\right)$ & $\mathrm{C}$ & Sig & 1 & $\begin{array}{c}\text { Roca and } \\
\text { Sedaghatkish (1998) }\end{array}$ & \\
\hline $26 \mathrm{Jul} 1996$ & $\begin{array}{c}\text { Between Leeward } \\
\text { Channel and } \\
\text { Hicacal Beach, } \\
\text { GTMO }\end{array}$ & $\left(19^{\circ} 56.08^{\prime} \mathrm{N}, 75^{\circ} 9.95^{\circ} \mathrm{W}\right)$ & $\mathrm{C}$ & Sig & 5 & $\begin{array}{c}\text { Roca and } \\
\text { Sedaghatkish (1998) }\end{array}$ & Cow-calf pair \\
\hline 29 Jul 1996 & $\begin{array}{c}\text { Guantánamo River, } \\
\text { GTMO }\end{array}$ & $\left(19^{\circ} 54.76^{\prime} \mathrm{N}, 75^{\circ} 11.71^{\prime} \mathrm{W}\right)$ & $\mathrm{C}$ & Sig & 1 & $\begin{array}{c}\text { Roca and } \\
\text { Sedaghatkish (1998) }\end{array}$ & \\
\hline 17 Jun 1999 & $\begin{array}{l}\text { Caravella Point, } \\
\text { GTMO }\end{array}$ & $\left(19^{\circ} 56.19^{\prime} \mathrm{N}, 75^{\circ} 7.74^{\prime} \mathrm{W}\right)$ & $\mathrm{C}$ & Sig & 1 & GTMO unpub. data & \\
\hline 17 Jun 1999 & $\begin{array}{c}\text { Entrance Channel } \\
\text { at Dock of the Bay, } \\
\text { GTMO }\end{array}$ & $\left(19^{\circ} 56.08^{\prime} \mathrm{N}, 75^{\circ} 7.68^{\prime} \mathrm{W}\right)$ & $\mathrm{C}$ & Sig & 1 & GTMO unpub. data & \\
\hline 17 Jun 1999 & $\begin{array}{l}\text { Granadillo Bay, } \\
\text { GTMO }\end{array}$ & $\left(19^{\circ} 57.22^{\prime} \mathrm{N}, 75^{\circ} 7.01^{\prime} \mathrm{W}\right)$ & $\mathrm{C}$ & Sig & 1 & GTMO unpub. data & \\
\hline 17 Jun 1999 & $\begin{array}{l}\text { Leeward Point, } \\
\text { GTMO }\end{array}$ & $\left(19^{\circ} 54.70^{\prime} \mathrm{N}, 75^{\circ} 11.36^{\prime} \mathrm{W}\right)$ & $\mathrm{C}$ & Sig & 2 & GTMO unpub. data & One calf \\
\hline 17 Jun 1999 & $\begin{array}{l}\text { Salinas Point, } \\
\text { GTMO }\end{array}$ & $\left(19^{\circ} 58.15^{\prime} \mathrm{N}, 75^{\circ} 9.00^{\prime} \mathrm{W}\right)$ & $\mathrm{C}$ & Sig & 1 & GTMO unpub. data & \\
\hline 28 Sept 1999 & $\begin{array}{l}\text { Near Security Boat } \\
\text { Lock, GTMO }\end{array}$ & $\left(19^{\circ} 55.11^{\prime} \mathrm{N}, 75^{\circ} 8.60^{\circ} \mathrm{W}\right)$ & $\mathrm{C}$ & Sig & 2 & GTMO unpub. data & \\
\hline 18 Nov 1999 & $\begin{array}{l}\text { North of Leeward } \\
\text { Point, GTMO }\end{array}$ & $\left(19^{\circ} 12^{\prime} \mathrm{N}, 75^{\circ} 12^{\prime} \mathrm{W}\right)$ & $\mathrm{C}$ & Str & 1 & GTMO unpub. data & \\
\hline 30 Mar 2001 & $\begin{array}{l}\text { Glass Beach, } \\
\text { GTMO }\end{array}$ & $\left(19^{\circ} 54.76^{\prime} \mathrm{N}, 75^{\circ} 10.02^{\prime} \mathrm{W}\right)$ & $\mathrm{C}$ & Sig & 1 & GTMO unpub. data & \\
\hline 26 Apr 2001 & $\begin{array}{l}\text { Hicacal Beach, } \\
\text { GTMO }\end{array}$ & $\left(19^{\circ} 56.02^{\prime} \mathrm{N}, 75^{\circ} 10.76^{\prime} \mathrm{W}\right)$ & $\mathrm{C}$ & Sig & 1 & GTMO unpub. data & \\
\hline 26 Apr 2001 & $\begin{array}{c}\text { Guantánamo River, } \\
\text { GTMO }\end{array}$ & $\left(19^{\circ} 54.78^{\prime} \mathrm{N}, 75^{\circ} 11.73^{\prime} \mathrm{W}\right)$ & $\mathrm{C}$ & Sig & 1 & GTMO unpub. data & \\
\hline 29 Apr 2001 & $\begin{array}{c}\text { Fisherman's Point, } \\
\text { GTMO }\end{array}$ & $\left(19^{\circ} 55.20^{\prime} \mathrm{N}, 75^{\circ} 9.70^{\circ} \mathrm{W}\right)$ & $\mathrm{C}$ & Sig & 1 & GTMO unpub. data & \\
\hline 29 Apr 2001 & $\begin{array}{c}\text { Guantánamo River, } \\
\text { GTMO }\end{array}$ & $\left(19^{\circ} 54.80^{\prime} \mathrm{N}, 75^{\circ} 11.75^{\prime} \mathrm{W}\right)$ & $\mathrm{C}$ & Sig & 1 & GTMO unpub. data & \\
\hline 29 Apr 2001 & $\begin{array}{l}\text { Salinas Point, } \\
\text { GTMO }\end{array}$ & $\left(19^{\circ} 58.15^{\prime} \mathrm{N}, 75^{\circ} 9.12^{\prime} \mathrm{W}\right)$ & $\mathrm{C}$ & Sig & 2 & GTMO unpub. data & One calf \\
\hline 18 Jun 2001 & $\begin{array}{l}\text { Hicacal Beach, } \\
\text { GTMO }\end{array}$ & $\left(19^{\circ} 56.00^{\prime} \mathrm{N}, 75^{\circ} 10.80^{\prime} \mathrm{W}\right)$ & $\mathrm{C}$ & Sig & 5 & GTMO unpub. data & Two calves \\
\hline $20 \mathrm{Jul} 2001$ & $\begin{array}{l}\text { Caracoles Point, } \\
\text { GTMO }\end{array}$ & $\left(19^{\circ} 56.43^{\prime} \mathrm{N}, 75^{\circ} 9.02^{\prime} \mathrm{W}\right)$ & $\mathrm{C}$ & Sig & 2 & GTMO unpub. data & \\
\hline $25 \mathrm{Jul} 2001$ & $\begin{array}{l}\text { Hicacal Beach, } \\
\text { GTMO }\end{array}$ & $\left(19^{\circ} 56.05^{\prime} \mathrm{N}, 75^{\circ} 10.75^{\prime} \mathrm{W}\right)$ & $\mathrm{C}$ & Sig & 3 & GTMO unpub. data & \\
\hline 20 Oct 2001 & $\begin{array}{l}\text { Conde Beach, } \\
\text { GTMO }\end{array}$ & $\left(19^{\circ} 55.10^{\prime} \mathrm{N}, 75^{\circ} 8.63^{\prime} \mathrm{W}\right)$ & $\mathrm{C}$ & Sig & 1 & GTMO unpub. data & \\
\hline 20 Oct 2001 & $\begin{array}{c}\text { Security Boat Shed, } \\
\text { GTMO }\end{array}$ & $\left(19^{\circ} 55.11^{\prime} \mathrm{N}, 75^{\circ} 8.60^{\prime} \mathrm{W}\right)$ & $\mathrm{C}$ & Sig & 1 & GTMO unpub. data & \\
\hline 26 Oct 2001 & $\begin{array}{c}\text { Guantánamo River, } \\
\text { GTMO }\end{array}$ & $\left(19^{\circ} 54.78^{\prime} \mathrm{N}, 75^{\circ} 11.74^{\prime} \mathrm{W}\right)$ & $\mathrm{C}$ & Sig & 1 & GTMO unpub. data & \\
\hline 22 Apr 2002 & $\begin{array}{l}\text { Hicacal Beach, } \\
\text { GTMO }\end{array}$ & $\left(19^{\circ} 56.05^{\prime} \mathrm{N}, 75^{\circ} 10.71^{\prime} \mathrm{W}\right)$ & $\mathrm{C}$ & Sig & 1 & GTMO unpub. data & \\
\hline 22 Apr 2002 & $\begin{array}{l}\text { Hicacal Beach, } \\
\text { GTMO }\end{array}$ & $\left(19^{\circ} 56.02^{\prime} \mathrm{N}, 75^{\circ} 10.81^{\prime} \mathrm{W}\right)$ & $\mathrm{C}$ & Sig & 4 & GTMO unpub. data & One calf \\
\hline 23 May 2002 & $\begin{array}{c}\text { Guantánamo River, } \\
\text { GTMO }\end{array}$ & $\left(19^{\circ} 54.79^{\prime} \mathrm{N}, 75^{\circ} 11.73^{\prime} \mathrm{W}\right)$ & $\mathrm{C}$ & Sig & 1 & GTMO unpub. data & \\
\hline 23 May 2002 & $\begin{array}{l}\text { Corinaso Cove, } \\
\text { GTMO }\end{array}$ & $\left(19^{\circ} 54.80^{\prime} \mathrm{N}, 75^{\circ} 9.31^{\prime} \mathrm{W}\right)$ & $\mathrm{C}$ & Sig & 1 & GTMO unpub. data & \\
\hline 19 Jul 2002 & $\begin{array}{l}\text { Corinaso Cove, } \\
\text { GTMO }\end{array}$ & $\left(19^{\circ} 54.77^{\prime} \mathrm{N}, 75^{\circ} 9.37^{\prime} \mathrm{W}\right)$ & $\mathrm{C}$ & Sig & 4 & GTMO unpub. data & Two calves \\
\hline $28 \mathrm{Jul} 2002$ & $\begin{array}{l}\text { MWR Marina } \\
\text { Ramp, GTMO }\end{array}$ & $\left(19^{\circ} 55.56^{\prime} \mathrm{N}, 75^{\circ} 8.33^{\prime} \mathrm{W}\right)$ & $\mathrm{C}$ & Sig & 3 & GTMO unpub. data & One calf \\
\hline 1 Aug 2002 & $\begin{array}{l}\text { Corinaso Cove, } \\
\text { GTMO }\end{array}$ & $\left(19^{\circ} 54.78^{\prime} \mathrm{N}, 75^{\circ} 9.37^{\prime} \mathrm{W}\right)$ & $\mathrm{C}$ & Sig & 2 & GTMO unpub. data & \\
\hline
\end{tabular}




\begin{tabular}{|c|c|c|c|c|c|c|c|}
\hline Species/Date & Location & Position & Status $^{\mathrm{a}}$ & Type $^{b}$ & $\begin{array}{l}\text { Group } \\
\text { Size }\end{array}$ & Source $^{c}$ & Comments \\
\hline 17 Aug 2002 & $\begin{array}{l}\text { Hicacal Beach, } \\
\text { GTMO }\end{array}$ & $\left(19^{\circ} 56.03^{\prime} \mathrm{N}, 75^{\circ} 10.77^{\prime} \mathrm{W}\right)$ & $\mathrm{C}$ & Sig & 1 & $\begin{array}{l}\text { GTMO unpub. } \\
\text { data }\end{array}$ & \\
\hline 25 Aug 2002 & $\begin{array}{c}\text { Guantánamo River, } \\
\text { GTMO }\end{array}$ & $\left(19^{\circ} 54.78^{\prime} \mathrm{N}, 75^{\circ} 11.72^{\prime} \mathrm{W}\right)$ & $\mathrm{C}$ & Sig & 3 & $\begin{array}{l}\text { GTMO unpub. } \\
\text { data }\end{array}$ & One calf \\
\hline 2003 & $\begin{array}{c}\text { Caravella Point, } \\
\text { GTMO }\end{array}$ & $\left(19^{\circ} 56.19^{\prime} \mathrm{N}, 75^{\circ} 7.74^{\prime} \mathrm{W}\right)$ & $\mathrm{C}$ & Sig & 1 & $\begin{array}{l}\text { GTMO unpub. } \\
\text { data }\end{array}$ & \\
\hline 2003 & $\begin{array}{l}\text { Conde Beach, } \\
\text { GTMO }\end{array}$ & $\left(19^{\circ} 55.71^{\prime} \mathrm{N}, 75^{\circ} 11.40^{\prime} \mathrm{W}\right)$ & $\mathrm{C}$ & Sig & 6 & $\begin{array}{l}\text { GTMO unpub. } \\
\text { data }\end{array}$ & Two calves \\
\hline 2003 & $\begin{array}{l}\text { Conde Beach, } \\
\text { GTMO }\end{array}$ & $\left(19^{\circ} 55.79^{\prime} \mathrm{N}, 75^{\circ} 11.26^{\prime} \mathrm{W}\right)$ & $\mathrm{C}$ & Sig & 1 & $\begin{array}{l}\text { GTMO unpub. } \\
\text { data }\end{array}$ & \\
\hline 2003 & $\begin{array}{l}\text { Desal Plant, } \\
\text { GTMO }\end{array}$ & $\left(19^{\circ} 55.13^{\prime} \mathrm{N}, 75^{\circ} 9.49^{\prime} \mathrm{W}\right)$ & $\mathrm{C}$ & Sig & 2 & $\begin{array}{l}\text { GTMO unpub. } \\
\text { data }\end{array}$ & One calf \\
\hline 2003 & $\begin{array}{c}\text { Desal Plant, } \\
\text { GTMO }\end{array}$ & $\left(19^{\circ} 55.11^{\prime} \mathrm{N}, 75^{\circ} 9.50^{\prime} \mathrm{W}\right)$ & $\mathrm{C}$ & Sig & 2 & $\begin{array}{l}\text { GTMO unpub. } \\
\text { data }\end{array}$ & One calf \\
\hline 2003 & $\begin{array}{c}\text { Fisherman's Point, } \\
\text { GTMO }\end{array}$ & $\left(19^{\circ} 55.16^{\prime} \mathrm{N}, 75^{\circ} 9.85^{\prime} \mathrm{W}\right)$ & $\mathrm{C}$ & Sig & 1 & $\begin{array}{l}\text { GTMO unpub. } \\
\text { data }\end{array}$ & \\
\hline 2003 & $\begin{array}{c}\text { Fisherman's Point, } \\
\text { GTMO }\end{array}$ & $\left(19^{\circ} 55.19^{\prime} \mathrm{N}, 75^{\circ} 9.78^{\prime} \mathrm{W}\right)$ & $\mathrm{C}$ & Sig & 2 & $\begin{array}{l}\text { GTMO unpub. } \\
\text { data }\end{array}$ & One calf \\
\hline 2003 & $\begin{array}{c}\text { Guantánamo River, } \\
\text { GTMO }\end{array}$ & $\left(19^{\circ} 54.80^{\prime} \mathrm{N}, 75^{\circ} 11.74^{\prime} \mathrm{W}\right)$ & $\mathrm{C}$ & Sig & 1 & $\begin{array}{l}\text { GTMO unpub. } \\
\text { data }\end{array}$ & \\
\hline 2003 & $\begin{array}{c}\text { Hicacal Beach, } \\
\text { GTMO }\end{array}$ & $\left(19^{\circ} 56.04^{\prime} \mathrm{N}, 75^{\circ} 10.73^{\prime} \mathrm{W}\right)$ & $\mathrm{C}$ & Sig & 7 & $\begin{array}{c}\text { GTMO unpub. } \\
\text { data }\end{array}$ & Three calves \\
\hline 2003 & $\begin{array}{c}\text { St. Nicholas } \\
\text { Channel, GTMO }\end{array}$ & $\left(19^{\circ} 54.74^{\prime} \mathrm{N}, 75^{\circ} 11.56^{\prime} \mathrm{W}\right)$ & $\mathrm{C}$ & Sig & 1 & $\begin{array}{l}\text { GTMO unpub. } \\
\text { data }\end{array}$ & \\
\hline 2003 & $\begin{array}{c}\text { St. Nicholas } \\
\text { Channel, GTMO }\end{array}$ & $\left(19^{\circ} 54.78^{\prime} \mathrm{N}, 75^{\circ} 11.54^{\prime} \mathrm{W}\right)$ & $\mathrm{C}$ & Sig & 1 & $\begin{array}{l}\text { GTMO unpub. } \\
\text { data }\end{array}$ & \\
\hline 2003 & $\begin{array}{c}\text { St. Nicholas } \\
\text { Channel, GTMO }\end{array}$ & $\left(19^{\circ} 54.73^{\prime} \mathrm{N}, 75^{\circ} 11.58^{\prime} \mathrm{W}\right)$ & $\mathrm{C}$ & Sig & 2 & $\begin{array}{l}\text { GTMO unpub. } \\
\text { data }\end{array}$ & One calf \\
\hline 19 Feb 2003 & $\begin{array}{c}\text { St. Nicholas } \\
\text { Channel, GTMO }\end{array}$ & $\left(19^{\circ} 54.75^{\prime} \mathrm{N}, 75^{\circ} 11.53^{\prime} \mathrm{W}\right)$ & $\mathrm{C}$ & Sig & 3 & $\begin{array}{c}\text { GTMO unpub. } \\
\text { data }\end{array}$ & \\
\hline 23 Mar 2003 & $\begin{array}{l}\text { Conde Beach, } \\
\text { GTMO }\end{array}$ & $\left(19^{\circ} 55.70^{\prime} \mathrm{N}, 75^{\circ} 11.44^{\prime} \mathrm{W}\right)$ & $\mathrm{C}$ & Sig & 4 & $\begin{array}{l}\text { GTMO unpub. } \\
\text { data }\end{array}$ & One calf \\
\hline 31 Mar 2003 & $\begin{array}{c}\text { Granadillo Bay, } \\
\text { GTMO }\end{array}$ & $\left(19^{\circ} 57.22^{\prime} \mathrm{N}, 75^{\circ} 7.01^{\prime} \mathrm{W}\right)$ & $\mathrm{C}$ & Sig & 1 & $\begin{array}{l}\text { GTMO unpub. } \\
\text { data }\end{array}$ & \\
\hline 9 Apr 2003 & $\begin{array}{c}\text { Guantánamo River, } \\
\text { GTMO }\end{array}$ & $\left(19^{\circ} 54.79^{\prime} \mathrm{N}, 75^{\circ} 11.75^{\prime} \mathrm{W}\right)$ & $\mathrm{C}$ & Sig & 1 & $\begin{array}{l}\text { GTMO unpub. } \\
\text { data }\end{array}$ & \\
\hline 21 Apr 2003 & $\begin{array}{l}\text { Conde Beach, } \\
\text { GTMO }\end{array}$ & $\left(19^{\circ} 55.74^{\prime} \mathrm{N}, 75^{\circ} 11.35^{\prime} \mathrm{W}\right)$ & $\mathrm{C}$ & Sig & 4 & $\begin{array}{c}\text { GTMO unpub. } \\
\text { data }\end{array}$ & \\
\hline 22 Apr 2003 & $\begin{array}{l}\text { Conde Beach, } \\
\text { GTMO }\end{array}$ & $\left(19^{\circ} 55.76^{\prime} \mathrm{N}, 75^{\circ} 11.28^{\prime} \mathrm{W}\right)$ & $\mathrm{C}$ & Sig & 2 & $\begin{array}{c}\text { GTMO unpub. } \\
\text { data }\end{array}$ & \\
\hline 22 Apr 2003 & $\begin{array}{c}\text { Guantánamo River, } \\
\text { GTMO }\end{array}$ & $\left(19^{\circ} 54.81^{\prime} \mathrm{N}, 75^{\circ} 11.76^{\prime} \mathrm{W}\right)$ & $\mathrm{C}$ & Sig & 2 & $\begin{array}{c}\text { GTMO unpub. } \\
\text { data }\end{array}$ & \\
\hline 25 Apr 2003 & $\begin{array}{c}\text { St. Nicholas } \\
\text { Channel, GTMO }\end{array}$ & $\left(19^{\circ} 54.73^{\prime} \mathrm{N}, 75^{\circ} 11.53^{\prime} \mathrm{W}\right)$ & $\mathrm{C}$ & Sig & 2 & $\begin{array}{c}\text { GTMO unpub. } \\
\text { data }\end{array}$ & \\
\hline 4 May 2003 & $\begin{array}{c}\text { Fisherman's Point, } \\
\text { GTMO }\end{array}$ & $\left(19^{\circ} 55.21^{\prime} \mathrm{N}, 75^{\circ} 9.63^{\prime} \mathrm{W}\right)$ & $\mathrm{C}$ & Sig & 1 & $\begin{array}{c}\text { GTMO unpub. } \\
\text { data }\end{array}$ & \\
\hline 4 May 2003 & $\begin{array}{c}\text { St. Nicholas } \\
\text { Channel, GTMO }\end{array}$ & $\left(19^{\circ} 54.76^{\prime} \mathrm{N}, 75^{\circ} 11.57^{\prime} \mathrm{W}\right)$ & $\mathrm{C}$ & Sig & 2 & $\begin{array}{c}\text { GTMO unpub. } \\
\text { data }\end{array}$ & \\
\hline 14 Nov 2004 & $\begin{array}{c}\text { Entrance Channel } \\
\text { at Dock of the Bay, } \\
\text { GTMO }\end{array}$ & $\left(19^{\circ} 56.06^{\prime} \mathrm{N}, 75^{\circ} 7.68^{\prime} \mathrm{W}\right)$ & $\mathrm{C}$ & Sig & 1 & $\begin{array}{l}\text { GTMO unpub. } \\
\text { data }\end{array}$ & \\
\hline 25 Sept 2005 & $\begin{array}{c}\text { Guantánamo River, } \\
\text { GTMO }\end{array}$ & $\left(19^{\circ} 54.79^{\prime} \mathrm{N}, 75^{\circ} 11.72^{\prime} \mathrm{W}\right)$ & $\mathrm{C}$ & Sig & 1 & $\begin{array}{l}\text { GTMO unpub. } \\
\text { data }\end{array}$ & \\
\hline 25 Sept 2005 & $\begin{array}{c}\text { St. Nicholas } \\
\text { Channel, GTMO }\end{array}$ & $\left(19^{\circ} 54.76^{\prime} \mathrm{N}, 75^{\circ} 11.54^{\prime} \mathrm{W}\right)$ & $\mathrm{C}$ & Sig & 1 & $\begin{array}{l}\text { GTMO unpub. } \\
\text { data }\end{array}$ & \\
\hline 2 March 2006 & $\begin{array}{l}\text { Near Hospital } \\
\text { Cove, GTMO }\end{array}$ & $\left(19^{\circ} 56.46^{\prime} \mathrm{N}, 75^{\circ} 7.16^{\prime} \mathrm{W}\right)$ & $\mathrm{C}$ & Sig & 1 & $\begin{array}{l}\text { GTMO unpub. } \\
\text { data }\end{array}$ & \\
\hline 11 March 2006 & $\begin{array}{l}\text { Near St. Nicholas } \\
\text { Channel, GTMO }\end{array}$ & $\left(19^{\circ} 54.59^{\prime} \mathrm{N}, 75^{\circ} 11.34^{\prime} \mathrm{W}\right)$ & $\mathrm{C}$ & Sig & 1 & $\begin{array}{l}\text { GTMO unpub. } \\
\text { data }\end{array}$ & \\
\hline 12 March 2006 & $\begin{array}{c}\text { Near Officer } \\
\text { Landing, GTMO }\end{array}$ & $\left(19^{\circ} 55.39^{\prime} \mathrm{N}, 75^{\circ} 8.43^{\prime} \mathrm{W}\right)$ & $\mathrm{C}$ & Sig & 1 & $\begin{array}{l}\text { GTMO unpub. } \\
\text { data }\end{array}$ & \\
\hline 12 March 2006 & $\begin{array}{c}\text { Near Pier 33, } \\
\text { GTMO }\end{array}$ & N/A & $\mathrm{C}$ & Sig & 1 & $\begin{array}{l}\text { GTMO unpub. } \\
\text { data }\end{array}$ & \\
\hline 14 March 2006 & $\begin{array}{c}\text { Near Marker 8, } \\
\text { GTMO }\end{array}$ & $\left(19^{\circ} 56.07^{\prime} \mathrm{N}, 75^{\circ} 8.90^{\prime} \mathrm{W}\right)$ & $\mathrm{C}$ & Sig & 1 & $\begin{array}{l}\text { GTMO unpub. } \\
\text { data }\end{array}$ & \\
\hline 29 March 2006 & $\begin{array}{c}\text { Near Officer } \\
\text { Landing, GTMO }\end{array}$ & $\left(19^{\circ} 55.39^{\prime} \mathrm{N}, 75^{\circ} 8.43^{\prime} \mathrm{W}\right)$ & $\mathrm{C}$ & Sig & 1 & $\begin{array}{l}\text { GTMO unpub. } \\
\text { data }\end{array}$ & \\
\hline
\end{tabular}




\begin{tabular}{|c|c|c|c|c|c|c|c|}
\hline Species/Date & Location & Position & Status $^{\mathrm{a}}$ & Type $^{b}$ & $\begin{array}{l}\text { Group } \\
\text { Size }\end{array}$ & Source $^{c}$ & Comments \\
\hline $\begin{array}{l}31 \text { March } \\
2006\end{array}$ & $\begin{array}{c}\text { Near Officer } \\
\text { Landing, GTMO }\end{array}$ & $\left(19^{\circ} 55.39^{\prime} \mathrm{N}, 75^{\circ} 8.43^{\prime} \mathrm{W}\right)$ & $\mathrm{C}$ & Sig & 1 & $\begin{array}{l}\text { GTMO unpub. } \\
\text { data }\end{array}$ & \\
\hline 4 April 2006 & $\begin{array}{l}\text { Near St. Nicholas } \\
\text { Channel, GTMO }\end{array}$ & $\left(19^{\circ} 54.56^{\prime} \mathrm{N}, 75^{\circ} 11.39^{\prime} \mathrm{W}\right)$ & $\mathrm{C}$ & Sig & 1 & $\begin{array}{c}\text { GTMO unpub. } \\
\text { data }\end{array}$ & \\
\hline 13 April 2006 & $\begin{array}{l}\text { Near Small Craft } \\
\text { Channel, GTMO }\end{array}$ & $\left(19^{\circ} 55.17^{\prime} \mathrm{N}, 75^{\circ} 8.71^{\prime} \mathrm{W}\right)$ & $\mathrm{C}$ & Sig & 1 & $\begin{array}{c}\text { GTMO unpub. } \\
\text { data }\end{array}$ & \\
\hline 13 April 2006 & $\begin{array}{l}\text { Near Boat Shed, } \\
\text { GTMO }\end{array}$ & $\left(19^{\circ} 56.11^{\prime} \mathrm{N}, 75^{\circ} 8.61^{\prime} \mathrm{W}\right)$ & $\mathrm{C}$ & Sig & 1 & $\begin{array}{c}\text { GTMO unpub. } \\
\text { data }\end{array}$ & \\
\hline 16 April 2006 & $\begin{array}{l}\text { Near Buoy 3, } \\
\text { GTMO }\end{array}$ & $\left(19^{\circ} 55.49^{\prime} \mathrm{N}, 75^{\circ} 10.30^{\prime} \mathrm{W}\right)$ & $\mathrm{C}$ & Sig & 1 & $\begin{array}{c}\text { GTMO unpub. } \\
\text { data }\end{array}$ & \\
\hline 18 April 2006 & $\begin{array}{l}\text { Near St. Nicholas } \\
\text { Channel, GTMO }\end{array}$ & $\left(19^{\circ} 54.63^{\prime} \mathrm{N}, 75^{\circ} 11.38^{\prime} \mathrm{W}\right)$ & $\mathrm{C}$ & Sig & 1 & $\begin{array}{l}\text { GTMO unpub. } \\
\text { data }\end{array}$ & \\
\hline 21 April 2006 & $\begin{array}{l}\text { Near Buoy 5, } \\
\text { GTMO }\end{array}$ & $\left(19^{\circ} 55.85^{\prime} \mathrm{N}, 75^{\circ} 10.14^{\prime} \mathrm{W}\right)$ & $\mathrm{C}$ & Sig & 1 & $\begin{array}{c}\text { GTMO unpub. } \\
\text { data }\end{array}$ & \\
\hline 2 May 2006 & $\begin{array}{l}\text { Near St. Nicholas } \\
\text { Channel, GTMO }\end{array}$ & $\left(19^{\circ} 54.59^{\prime} \mathrm{N}, 75^{\circ} 11.37^{\prime} \mathrm{W}\right)$ & $\mathrm{C}$ & Sig & 3 & $\begin{array}{c}\text { GTMO unpub. } \\
\text { data }\end{array}$ & \\
\hline 7 May 2006 & $\begin{array}{l}\text { Near St. Nicholas } \\
\text { Channel, GTMO }\end{array}$ & $\left(19^{\circ} 54.58^{\prime} \mathrm{N}, 75^{\circ} 11.42^{\prime} \mathrm{W}\right)$ & $\mathrm{C}$ & Sig & 2 & $\begin{array}{c}\text { GTMO unpub. } \\
\text { data }\end{array}$ & \\
\hline 10 May 2006 & $\begin{array}{c}\text { St. Nicholas } \\
\text { Channel, GTMO }\end{array}$ & $\left(19^{\circ} 54.61^{\prime} \mathrm{N}, 75^{\circ} 11.39^{\prime} \mathrm{W}\right)$ & $\mathrm{C}$ & Sig & 1 & $\begin{array}{c}\text { GTMO unpub. } \\
\text { data }\end{array}$ & \\
\hline 11 May 2006 & $\begin{array}{c}\text { St. Nicholas } \\
\text { Channel, GTMO }\end{array}$ & $\left(19^{\circ} 54.58^{\prime} \mathrm{N}, 75^{\circ} 11.39^{\prime} \mathrm{W}\right)$ & $\mathrm{C}$ & Sig & 2 & $\begin{array}{c}\text { GTMO unpub. } \\
\text { data }\end{array}$ & \\
\hline 18 May 2006 & $\begin{array}{c}\text { Mouth of St. } \\
\text { Nicholas Channel, } \\
\text { GTMO }\end{array}$ & $\left(19^{\circ} 54.57^{\prime} \mathrm{N}, 75^{\circ} 11.41^{\prime} \mathrm{W}\right)$ & $\mathrm{C}$ & Sig & 2 & $\begin{array}{l}\text { GTMO unpub. } \\
\text { data }\end{array}$ & \\
\hline 18 May 2006 & $\begin{array}{l}\text { Water Gate near } \\
\text { Hospital Cove, } \\
\text { GTMO }\end{array}$ & N/A & $\mathrm{C}$ & Sig & 2 & $\begin{array}{l}\text { GTMO unpub. } \\
\text { data }\end{array}$ & \\
\hline 18 May 2006 & $\begin{array}{c}\text { Mouth of St. } \\
\text { Nicholas Channel, } \\
\text { GTMO }\end{array}$ & $\left(19^{\circ} 54.55^{\prime} \mathrm{N}, 75^{\circ} 11.41^{\prime} \mathrm{W}\right)$ & $\mathrm{C}$ & Sig & 4 & $\begin{array}{l}\text { GTMO unpub. } \\
\text { data }\end{array}$ & \\
\hline 20 May 2006 & $\begin{array}{c}\text { St. Nicholas } \\
\text { Channel, GTMO }\end{array}$ & $\left(19^{\circ} 54.67^{\prime} \mathrm{N}, 75^{\circ} 11.39^{\circ} \mathrm{W}\right)$ & $\mathrm{C}$ & Sig & 1 & $\begin{array}{c}\text { GTMO unpub. } \\
\text { data }\end{array}$ & \\
\hline 24 May 2006 & $\begin{array}{l}\text { Near St. Nicholas } \\
\text { Channel, GTMO }\end{array}$ & $\left(19^{\circ} 54.66^{\prime} \mathrm{N}, 75^{\circ} 11.41^{\prime} \mathrm{W}\right)$ & $\mathrm{C}$ & Sig & 1 & $\begin{array}{l}\text { GTMO unpub. } \\
\text { data }\end{array}$ & \\
\hline 26 May 2006 & $\begin{array}{c}\text { St. Nicholas } \\
\text { Channel, GTMO }\end{array}$ & $\left(19^{\circ} 54.59^{\prime} \mathrm{N}, 75^{\circ} 11.38^{\prime} \mathrm{W}\right)$ & C & Sig & 1 & $\begin{array}{c}\text { GTMO unpub. } \\
\text { data }\end{array}$ & \\
\hline 27 May 2006 & $\begin{array}{c}\text { St. Nicholas } \\
\text { Channel, GTMO }\end{array}$ & $\left(19^{\circ} 54.59^{\prime} \mathrm{N}, 75^{\circ} 11.43^{\prime} \mathrm{W}\right)$ & C & Sig & 1 & $\begin{array}{l}\text { GTMO unpub. } \\
\text { data }\end{array}$ & \\
\hline 30 May 2006 & $\begin{array}{c}\text { St. Nicholas } \\
\text { Channel, GTMO }\end{array}$ & $\left(19^{\circ} 54.56^{\prime} \mathrm{N}, 75^{\circ} 11.43^{\prime} \mathrm{W}\right)$ & $\mathrm{C}$ & Sig & 1 & $\begin{array}{l}\text { GTMO unpub. } \\
\text { data }\end{array}$ & \\
\hline 4 June 2006 & $\begin{array}{l}\text { Near Buoy 1, } \\
\text { GTMO }\end{array}$ & $\left(19^{\circ} 54.76^{\prime} \mathrm{N}, 75^{\circ} 10.35^{\prime} \mathrm{W}\right)$ & $\mathrm{C}$ & Sig & 1 & $\begin{array}{l}\text { GTMO unpub. } \\
\text { data }\end{array}$ & \\
\hline 8 June 2006 & $\begin{array}{l}\text { Near St. Nicholas } \\
\text { Channel, GTMO }\end{array}$ & $\left(19^{\circ} 54.56^{\prime} \mathrm{N}, 75^{\circ} 11.35^{\prime} \mathrm{W}\right)$ & $\mathrm{C}$ & Sig & 1 & $\begin{array}{c}\text { GTMO unpub. } \\
\text { data }\end{array}$ & \\
\hline 11 June 2006 & $\begin{array}{l}\text { Near Corinaso } \\
\text { Point/Cove, } \\
\text { GTMO }\end{array}$ & $\left(19^{\circ} 55.09^{\prime} \mathrm{N}, 75^{\circ} 9.25^{\prime} \mathrm{W}\right)$ & $\mathrm{C}$ & Sig & 2 & $\begin{array}{l}\text { GTMO unpub. } \\
\text { data }\end{array}$ & \\
\hline 11 June 2006 & $\begin{array}{l}\text { Near St. Nicholas } \\
\text { Channel, GTMO }\end{array}$ & $\left(19^{\circ} 54.52^{\prime} \mathrm{N}, 75^{\circ} 11.42^{\prime} \mathrm{W}\right)$ & $\mathrm{C}$ & Sig & 1 & $\begin{array}{c}\text { GTMO unpub. } \\
\text { data }\end{array}$ & \\
\hline 15 June 2006 & $\begin{array}{c}\text { Near Hicacle Beach, } \\
\text { GTMO }\end{array}$ & $\left(19^{\circ} 56.07^{\prime} \mathrm{N}, 75^{\circ} 10.70^{\prime} \mathrm{W}\right)$ & $\mathrm{C}$ & Sig & 1 & $\begin{array}{l}\text { GTMO unpub. } \\
\text { data }\end{array}$ & \\
\hline 17 June 2006 & $\begin{array}{c}\text { St. Nicholas } \\
\text { Channel, GTMO }\end{array}$ & $\left(19^{\circ} 54.52^{\prime} \mathrm{N}, 75^{\circ} 11.38^{\prime} \mathrm{W}\right)$ & $\mathrm{C}$ & Sig & 1 & $\begin{array}{c}\text { GTMO unpub. } \\
\text { data }\end{array}$ & \\
\hline 20 June 2006 & $\begin{array}{l}\text { Near Buoy 2, } \\
\text { GTMO }\end{array}$ & $\left(19^{\circ} 54.61^{\prime} \mathrm{N}, 75^{\circ} 11.38^{\prime} \mathrm{W}\right)$ & $\mathrm{C}$ & Sig & 1 & $\begin{array}{l}\text { GTMO unpub. } \\
\text { data }\end{array}$ & \\
\hline 22 June 2006 & $\begin{array}{l}\text { Near St. Nicholas } \\
\text { Channel, GTMO }\end{array}$ & $\left(19^{\circ} 54.61^{\prime} \mathrm{N}, 75^{\circ} 11.37^{\prime} \mathrm{W}\right)$ & $\mathrm{C}$ & Sig & 1 & $\begin{array}{l}\text { GTMO unpub. } \\
\text { data }\end{array}$ & \\
\hline 22 June 2006 & $\begin{array}{l}\text { Near St. Nicholas } \\
\text { Channel, GTMO }\end{array}$ & $\left(19^{\circ} 54.68^{\prime} \mathrm{N}, 75^{\circ} 11.41^{\prime} \mathrm{W}\right)$ & $\mathrm{C}$ & Sig & 1 & $\begin{array}{l}\text { GTMO unpub. } \\
\text { data }\end{array}$ & \\
\hline 24 June 2006 & $\begin{array}{c}\text { St. Nicholas } \\
\text { Channel, GTMO }\end{array}$ & $\left(19^{\circ} 54.60^{\prime} \mathrm{N}, 75^{\circ} 11.32^{\prime} \mathrm{W}\right)$ & $\mathrm{C}$ & Sig & 1 & $\begin{array}{c}\text { GTMO unpub. } \\
\text { data }\end{array}$ & \\
\hline 24 June 2006 & $\begin{array}{c}\text { St. Nicholas } \\
\text { Channel, GTMO }\end{array}$ & $\left(19^{\circ} 54.64^{\prime} \mathrm{N}, 75^{\circ} 11.34^{\prime} \mathrm{W}\right)$ & $\mathrm{C}$ & Sig & 1 & $\begin{array}{c}\text { GTMO unpub. } \\
\text { data }\end{array}$ & \\
\hline 26 June 2006 & $\begin{array}{c}\text { St. Nicholas } \\
\text { Channel, GTMO }\end{array}$ & $\left(19^{\circ} 54.58^{\prime} \mathrm{N}, 75^{\circ} 11.34^{\prime} \mathrm{W}\right)$ & $\mathrm{C}$ & Sig & 1 & $\begin{array}{c}\text { GTMO unpub. } \\
\text { data }\end{array}$ & \\
\hline 26 June 2006 & $\begin{array}{c}\text { Leeward Ferry } \\
\text { Landing, GTMO }\end{array}$ & $\left(19^{\circ} 54.60^{\prime} \mathrm{N}, 75^{\circ} 11.41^{\prime} \mathrm{W}\right)$ & C & Sig & 1 & $\begin{array}{c}\text { GTMO unpub. } \\
\text { data }\end{array}$ & \\
\hline
\end{tabular}




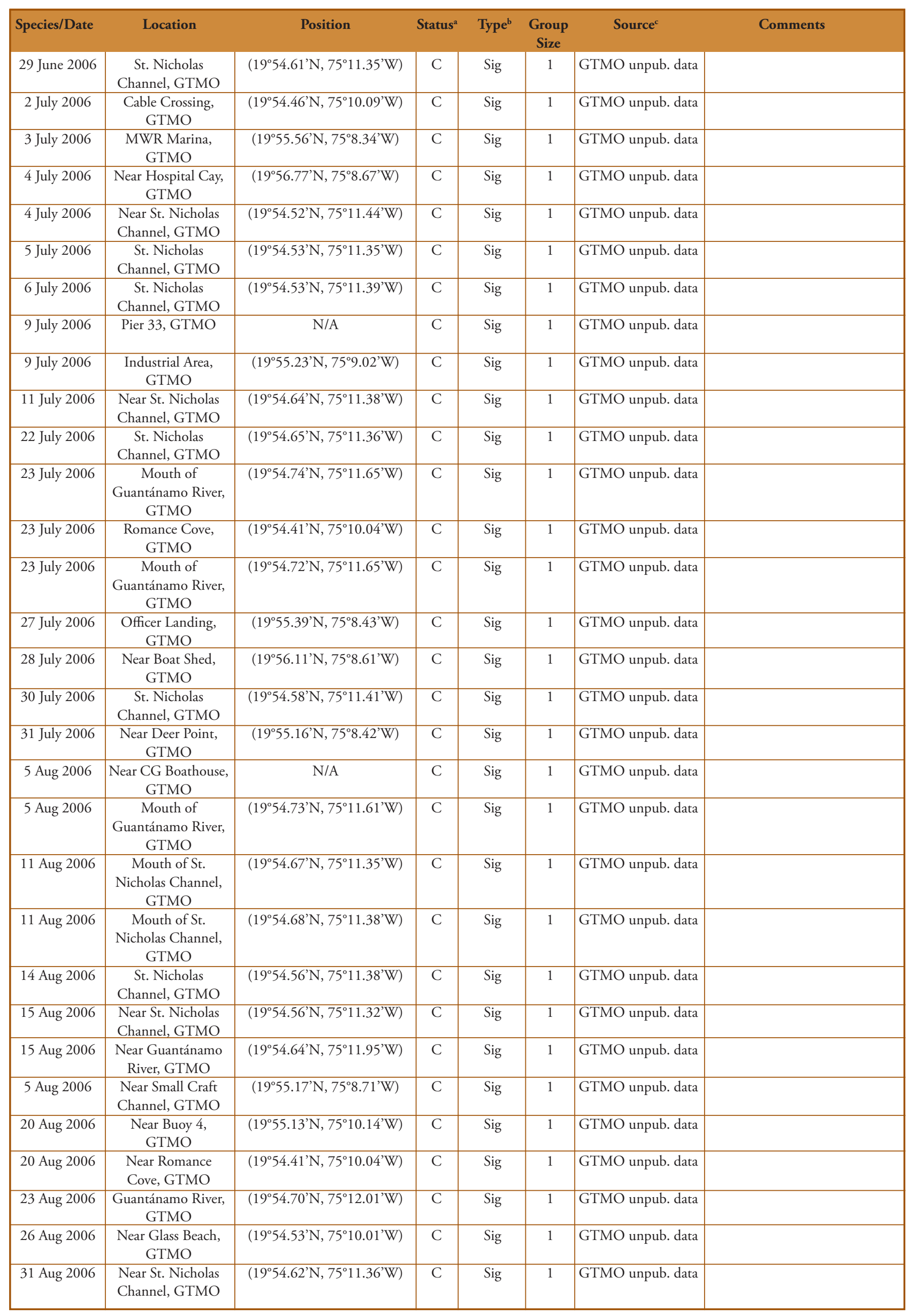




\begin{tabular}{|c|c|c|c|c|c|c|c|}
\hline Species/Date & Location & Position & Status $^{a}$ & Type $^{b}$ & $\begin{array}{l}\text { Group } \\
\text { Size }\end{array}$ & Source $^{c}$ & Comments \\
\hline 4 Sept 2006 & $\begin{array}{c}\text { Guantánamo River, } \\
\text { GTMO }\end{array}$ & $\left(19^{\circ} 54.69^{\prime} \mathrm{N}, 75^{\circ} 11.96^{\prime} \mathrm{W}\right)$ & $\mathrm{C}$ & Sig & 1 & GTMO unpub. data & \\
\hline 5 Sept 2006 & $\begin{array}{c}\text { Mouth of } \\
\text { Guantánamo River, } \\
\text { GTMO }\end{array}$ & $\left(19^{\circ} 54.73^{\prime} \mathrm{N}, 75^{\circ} 11.68^{\prime} \mathrm{W}\right)$ & $\mathrm{C}$ & Sig & 1 & GTMO unpub. data & \\
\hline 7 Sept 2006 & $\begin{array}{c}\text { St. Nicholas } \\
\text { Channel, GTMO }\end{array}$ & $\left(19^{\circ} 54.47^{\prime} \mathrm{N}, 75^{\circ} 11.44^{\prime} \mathrm{W}\right)$ & $\mathrm{C}$ & Sig & 1 & GTMO unpub. data & \\
\hline 9 Sept 2006 & $\begin{array}{c}\text { Near Glass Beach, } \\
\text { GTMO }\end{array}$ & $\left(19^{\circ} 54.53^{\prime} \mathrm{N}, 75^{\circ} 10.01^{\prime} \mathrm{W}\right)$ & $\mathrm{C}$ & Sig & 1 & GTMO unpub. data & \\
\hline 9 Sept 2006 & $\begin{array}{l}\text { Philips Dive Park, } \\
\text { GTMO }\end{array}$ & $\left(19^{\circ} 53.90^{\prime} \mathrm{N}, 75^{\circ} 9.97^{\prime} \mathrm{W}\right)$ & $\mathrm{C}$ & Sig & 1 & GTMO unpub. data & \\
\hline 10 Sept 2006 & $\begin{array}{c}\text { St. Nicholas } \\
\text { Channel, GTMO }\end{array}$ & $\left(19^{\circ} 54.47^{\prime} \mathrm{N}, 75^{\circ} 11.41^{\prime} \mathrm{W}\right)$ & $\mathrm{C}$ & Sig & 1 & GTMO unpub. data & \\
\hline 13 Sept 2006 & $\begin{array}{c}\text { Guantánamo River, } \\
\text { GTMO }\end{array}$ & $\left(19^{\circ} 54.67^{\prime} \mathrm{N}, 75^{\circ} 12.20^{\prime} \mathrm{W}\right)$ & $\mathrm{C}$ & Sig & 1 & GTMO unpub. data & \\
\hline 14 Sept 2006 & $\begin{array}{l}\text { Near Granadillo } \\
\text { Point, GTMO }\end{array}$ & $\left(19^{\circ} 57.08^{\prime} \mathrm{N}, 75^{\circ} 7.08^{\prime} \mathrm{W}\right)$ & $\mathrm{C}$ & Sig & 1 & GTMO unpub. data & \\
\hline 15 Sept 2006 & $\begin{array}{c}\text { St. Nicholas } \\
\text { Channel, GTMO }\end{array}$ & $\left(19^{\circ} 54.49^{\prime} \mathrm{N}, 75^{\circ} 11.39^{\prime} \mathrm{W}\right)$ & C & Sig & 1 & GTMO unpub. data & \\
\hline 16 Sept 2006 & $\begin{array}{c}\text { St. Nicholas } \\
\text { Channel, GTMO }\end{array}$ & $\left(19^{\circ} 54.46^{\prime} \mathrm{N}, 75^{\circ} 11.38^{\prime} \mathrm{W}\right)$ & $\mathrm{C}$ & Sig & 1 & GTMO unpub. data & \\
\hline 21 Sept 2006 & $\begin{array}{c}\text { St. Nicholas } \\
\text { Channel, GTMO }\end{array}$ & $\left(19^{\circ} 54.48^{\prime} \mathrm{N}, 75^{\circ} 11.36^{\prime} \mathrm{W}\right)$ & $\mathrm{C}$ & Sig & 1 & GTMO unpub. data & \\
\hline 21 Sept 2006 & $\begin{array}{l}\text { Fisherman's Point, } \\
\text { GTMO }\end{array}$ & $\left(19^{\circ} 55.11^{\prime} \mathrm{N}, 75^{\circ} 9.51^{\prime} \mathrm{W}\right)$ & $\mathrm{C}$ & Sig & 1 & GTMO unpub. data & \\
\hline 26 Sept 2006 & $\begin{array}{l}\text { MWR Marina, } \\
\text { GTMO }\end{array}$ & $\left(19^{\circ} 55.56^{\prime} \mathrm{N}, 75^{\circ} 8.34^{\prime} \mathrm{W}\right)$ & $\mathrm{C}$ & Sig & 1 & GTMO unpub. data & \\
\hline 28 Sept 2006 & $\begin{array}{l}\text { Near Buoy 3, } \\
\text { GTMO }\end{array}$ & $\left(19^{\circ} 55.49^{\prime} \mathrm{N}, 75^{\circ} 10.30^{\prime} \mathrm{W}\right)$ & $\mathrm{C}$ & Sig & 1 & GTMO unpub. data & \\
\hline 28 Sept 2006 & $\begin{array}{c}\text { Near Pier 33, } \\
\text { GTMO }\end{array}$ & N/A & $\mathrm{C}$ & Sig & 1 & GTMO unpub. data & \\
\hline 30 Sept 2006 & $\begin{array}{l}\text { MWR Marina, } \\
\text { GTMO }\end{array}$ & $\left(19^{\circ} 55.56^{\prime} \mathrm{N}, 75^{\circ} 8.34^{\prime} \mathrm{W}\right)$ & $\mathrm{C}$ & Sig & 1 & GTMO unpub. data & \\
\hline 1 Oct 2006 & $\begin{array}{l}\text { Near Guantánamo } \\
\text { River, GTMO }\end{array}$ & $\left(19^{\circ} 54.68^{\prime} \mathrm{N}, 75^{\circ} 12.04^{\prime} \mathrm{W}\right)$ & $\mathrm{C}$ & Sig & 1 & GTMO unpub. data & \\
\hline 4 Oct 2006 & $\begin{array}{c}\text { Guantánamo River, } \\
\text { GTMO }\end{array}$ & $\left(19^{\circ} 54.69^{\prime} \mathrm{N}, 75^{\circ} 12.08^{\prime} \mathrm{W}\right)$ & $\mathrm{C}$ & Sig & 1 & GTMO unpub. data & \\
\hline 6 Oct 2006 & $\begin{array}{c}\text { St. Nicholas } \\
\text { Channel, GTMO }\end{array}$ & $\left(19^{\circ} 54.44^{\prime} \mathrm{N}, 75^{\circ} 11.43^{\prime} \mathrm{W}\right)$ & $\mathrm{C}$ & Sig & 1 & GTMO unpub. data & \\
\hline 6 Oct 2006 & $\begin{array}{l}\text { Leeward Landing, } \\
\text { GTMO }\end{array}$ & $\left(19^{\circ} 54.59^{\prime} \mathrm{N}, 75^{\circ} 11.42^{\prime} \mathrm{W}\right)$ & $\mathrm{C}$ & Sig & 1 & GTMO unpub. data & \\
\hline 8 Oct 2006 & $\begin{array}{c}\text { Near Buoy 1, } \\
\text { GTMO }\end{array}$ & $\left(19^{\circ} 54.76^{\prime} \mathrm{N}, 75^{\circ} 10.35^{\prime} \mathrm{W}\right)$ & $\mathrm{C}$ & Sig & 1 & GTMO unpub. data & \\
\hline 9 Oct 2006 & $\begin{array}{c}\text { Near Ferry Landing, } \\
\text { GTMO }\end{array}$ & $\left(19^{\circ} 55.16^{\prime} \mathrm{N}, 75^{\circ} 8.42^{\prime} \mathrm{W}\right)$ & $\mathrm{C}$ & Sig & 1 & GTMO unpub. data & \\
\hline 12 Oct 2006 & $\begin{array}{l}\text { Near St. Nicholas } \\
\text { Channel, GTMO }\end{array}$ & $\left(19^{\circ} 54.40^{\prime} \mathrm{N}, 75^{\circ} 11.47^{\prime} \mathrm{W}\right)$ & $\mathrm{C}$ & Sig & 1 & GTMO unpub. data & \\
\hline 14 Oct 2006 & $\begin{array}{c}\text { Between Buoy } 1 \text { and } \\
2, \text { GTMO }\end{array}$ & $\left(19^{\circ} 54.57^{\prime} \mathrm{N}, 75^{\circ} 10.75^{\prime} \mathrm{W}\right)$ & $\mathrm{C}$ & Sig & 1 & GTMO unpub. data & \\
\hline 16 Oct 2006 & $\begin{array}{c}\text { St. Nicholas } \\
\text { Channel, GTMO }\end{array}$ & $\left(19^{\circ} 54.42^{\prime} \mathrm{N}, 75^{\circ} 11.40^{\prime} \mathrm{W}\right)$ & $\mathrm{C}$ & Sig & 1 & GTMO unpub. data & \\
\hline 17 Oct 2006 & $\begin{array}{c}\text { Guantánamo River, } \\
\text { GTMO }\end{array}$ & $\left(19^{\circ} 54.76^{\prime} \mathrm{N}, 75^{\circ} 12.06^{\prime} \mathrm{W}\right)$ & $\mathrm{C}$ & Sig & 1 & GTMO unpub. data & \\
\hline 20 Oct 2006 & $\begin{array}{c}\text { St. Nicholas } \\
\text { Channel, GTMO }\end{array}$ & $\left(19^{\circ} 54.43^{\prime} \mathrm{N}, 75^{\circ} 11.37^{\prime} \mathrm{W}\right)$ & C & Sig & 1 & GTMO unpub. data & \\
\hline 23 Oct 2006 & $\begin{array}{c}\text { St. Nicholas } \\
\text { Channel, GTMO }\end{array}$ & $\left(19^{\circ} 54.39^{\prime} \mathrm{N}, 75^{\circ} 11.43^{\prime} \mathrm{W}\right)$ & $\mathrm{C}$ & Sig & 1 & GTMO unpub. data & \\
\hline 26 Oct 2006 & $\begin{array}{c}\text { St. Nicholas } \\
\text { Channel, GTMO }\end{array}$ & $\left(19^{\circ} 54.40^{\prime} \mathrm{N}, 75^{\circ} 11.39^{\prime} \mathrm{W}\right)$ & $\mathrm{C}$ & Sig & 1 & GTMO unpub. data & \\
\hline 28 Oct 2006 & $\begin{array}{c}\text { St. Nicholas } \\
\text { Channel, GTMO }\end{array}$ & $\left(19^{\circ} 54.45^{\prime} \mathrm{N}, 75^{\circ} 11.35^{\prime} \mathrm{W}\right)$ & $\mathrm{C}$ & Sig & 1 & GTMO unpub. data & \\
\hline 29 Oct 2006 & $\begin{array}{c}\text { Guantánamo River, } \\
\text { GTMO }\end{array}$ & $\left(19^{\circ} 54.76^{\prime} \mathrm{N}, 75^{\circ} 12.21^{\prime} \mathrm{W}\right)$ & $\mathrm{C}$ & Sig & 1 & GTMO unpub. data & \\
\hline 30 Oct 2006 & $\begin{array}{c}\text { Near Mouth } \\
\text { of Evans Point } \\
\text { Channel, GTMO }\end{array}$ & $\left(19^{\circ} 55.16^{\prime} \mathrm{N}, 75^{\circ} 8.42^{\prime} \mathrm{W}\right)$ & $\mathrm{C}$ & Sig & 1 & GTMO unpub. data & \\
\hline
\end{tabular}




\begin{tabular}{|c|c|c|c|c|c|c|c|}
\hline Species/Date & Location & Position & Status ${ }^{\mathrm{a}}$ & Type & $\begin{array}{l}\text { Group } \\
\text { Size }\end{array}$ & Source $^{c}$ & Comments \\
\hline 31 Oct 2006 & $\begin{array}{c}\text { St. Nicholas } \\
\text { Channel, GTMO }\end{array}$ & $\left(19^{\circ} 54.41^{\prime} \mathrm{N}, 75^{\circ} 11.43^{\prime} \mathrm{W}\right)$ & $\mathrm{C}$ & Sig & 1 & GTMO unpub. data & \\
\hline 5 Nov 2006 & $\begin{array}{l}\text { Near Buoy 4, } \\
\text { GTMO }\end{array}$ & $\left(19^{\circ} 55.13^{\prime} \mathrm{N}, 75^{\circ} 10.14^{\prime} \mathrm{W}\right)$ & $\mathrm{C}$ & Sig & 1 & GTMO unpub. data & \\
\hline 5 Nov 2006 & $\begin{array}{c}\text { St. Nicholas } \\
\text { Channel, GTMO }\end{array}$ & $\left(19^{\circ} 54.40^{\prime} \mathrm{N}, 75^{\circ} 11.38^{\prime} \mathrm{W}\right)$ & $\mathrm{C}$ & Sig & 1 & GTMO unpub. data & \\
\hline 9 Nov 2006 & $\begin{array}{c}\text { St. Nicholas } \\
\text { Channel, GTMO }\end{array}$ & $\left(19^{\circ} 54.38^{\prime} \mathrm{N}, 75^{\circ} 11.41^{\prime} \mathrm{W}\right)$ & $\mathrm{C}$ & Sig & 1 & GTMO unpub. data & \\
\hline 15 Nov 2006 & $\begin{array}{c}\text { Near Day Marker 5, } \\
\text { GTMO }\end{array}$ & $\mathrm{N} / \mathrm{A}$ & $\mathrm{C}$ & Sig & 1 & GTMO unpub. data & \\
\hline 19 Nov 2006 & $\begin{array}{l}\text { Near Romance } \\
\text { Cove, GTMO }\end{array}$ & $\left(19^{\circ} 54.41^{\prime} \mathrm{N}, 75^{\circ} 10.04^{\prime} \mathrm{W}\right)$ & $\mathrm{C}$ & Sig & 1 & GTMO unpub. data & \\
\hline 13 Jan 2007 & $\begin{array}{c}\text { St. Nicholas } \\
\text { Channel, GTMO }\end{array}$ & $\left(19^{\circ} 54.39^{\prime} \mathrm{N}, 75^{\circ} 11.48^{\prime} \mathrm{W}\right)$ & $\mathrm{C}$ & Sig & 1 & GTMO unpub. data & \\
\hline 18 Jan 2007 & $\begin{array}{c}\text { Camilo Cienfuegos } \\
\text { Power Plant, Santa } \\
\text { Cruz del Norte } \\
\end{array}$ & $\left(22^{\circ} 13.80^{\prime} \mathrm{N}, 81^{\circ} 55.83^{\prime} \mathrm{W}\right)$ & $\mathrm{C}$ & Sig & 2 & $\begin{array}{l}\text { Alvarez-Alemán et } \\
\text { al. (2010) }\end{array}$ & $\begin{array}{l}\text { Cow-calf pair; photographs } \\
\text { taken; cow identified as CR131 }\end{array}$ \\
\hline 27 Jan 2007 & $\begin{array}{c}\text { Near Industrial Area, } \\
\text { GTMO }\end{array}$ & $\left(19^{\circ} 55.23^{\prime} \mathrm{N}, 75^{\circ} 9.02^{\prime} \mathrm{W}\right)$ & $\mathrm{C}$ & Sig & 2 & GTMO unpub. data & \\
\hline 3 Feb 2007 & $\begin{array}{c}\text { Camilo Cienfuegos } \\
\text { Power Plant, Santa } \\
\text { Cruz del Norte }\end{array}$ & $\left(22^{\circ} 13.80^{\prime} \mathrm{N}, 81^{\circ} 55.83^{\prime} \mathrm{W}\right)$ & $\mathrm{C}$ & Sig & 2 & $\begin{array}{l}\text { Alvarez-Alemán et } \\
\text { al. (2010) }\end{array}$ & $\begin{array}{c}\text { Photo-ID matched to cow-calf } \\
\text { pair from previous Camilo } \\
\text { Cienfuegos record }\end{array}$ \\
\hline 11 Feb 2007 & $\begin{array}{c}\text { Mouth of St. } \\
\text { Nicholas Channel, } \\
\text { GTMO }\end{array}$ & $\left(19^{\circ} 54.37^{\prime} \mathrm{N}, 75^{\circ} 11.44^{\prime} \mathrm{W}\right)$ & $\mathrm{C}$ & Sig & 1 & GTMO unpub. data & \\
\hline 15 Feb 2007 & $\begin{array}{c}\text { Near Hospital } \\
\text { Landing, GTMO }\end{array}$ & N/A & $\mathrm{C}$ & Sig & 1 & GTMO unpub. data & \\
\hline 25 Mar 2007 & $\begin{array}{l}\text { Mouth of } \\
\text { Guantánamo River, } \\
\text { GTMO }\end{array}$ & $\left(19^{\circ} 54.73^{\prime} \mathrm{N}, 75^{\circ} 11.79^{\prime} \mathrm{W}\right)$ & $\mathrm{C}$ & Sig & 1 & GTMO unpub. data & \\
\hline 5 Apr 2007 & $\begin{array}{c}\text { Camilo Cienfuegos } \\
\text { Power Plant, Santa } \\
\text { Cruz del Norte }\end{array}$ & $\left(22^{\circ} 13.80^{\prime} \mathrm{N}, 81^{\circ} 55.83^{\prime} \mathrm{W}\right)$ & $\mathrm{C}$ & Sig & 2 & $\begin{array}{l}\text { Alvarez-Alemán et } \\
\text { al. (2010) }\end{array}$ & $\begin{array}{c}\text { Photo-ID matched to cow-calf } \\
\text { pair from previous Camilo } \\
\text { Cienfuegos record }\end{array}$ \\
\hline 11 Apr 2007 & $\begin{array}{c}\text { St. Nicholas } \\
\text { Channel, GTMO }\end{array}$ & $\left(19^{\circ} 54.37^{\prime} \mathrm{N}, 75^{\circ} 11.38^{\prime} \mathrm{W}\right)$ & $\mathrm{C}$ & Sig & 1 & GTMO unpub. data & \\
\hline 4 May 2007 & $\begin{array}{l}\text { Near Buoy 4, } \\
\text { GTMO }\end{array}$ & $\left(19^{\circ} 55.13^{\prime} \mathrm{N}, 75^{\circ} 10.14^{\prime} \mathrm{W}\right)$ & $\mathrm{C}$ & Sig & 1 & GTMO unpub. data & \\
\hline 27 May 2007 & $\begin{array}{l}\text { Near Buoy 1, } \\
\text { GTMO }\end{array}$ & $\left(19^{\circ} 54.76^{\prime} \mathrm{N}, 75^{\circ} 10.35^{\prime} \mathrm{W}\right)$ & $\mathrm{C}$ & Sig & 1 & GTMO unpub. data & \\
\hline 5 Jun 2007 & $\begin{array}{c}\text { St. Nicholas } \\
\text { Channel, GTMO }\end{array}$ & $\left(19^{\circ} 54.50^{\prime} \mathrm{N}, 75^{\circ} 11.34^{\prime} \mathrm{W}\right)$ & $\mathrm{C}$ & Sig & 1 & GTMO unpub. data & \\
\hline 12 Jun 2007 & $\begin{array}{c}\text { Guantánamo River, } \\
\text { GTMO }\end{array}$ & $\left(19^{\circ} 54.72^{\prime} \mathrm{N}, 75^{\circ} 11.75^{\prime} \mathrm{W}\right)$ & $\mathrm{C}$ & Sig & 1 & GTMO unpub. data & \\
\hline 28 Jun 2007 & $\begin{array}{l}\text { MWR Marina, } \\
\text { GTMO }\end{array}$ & $\left(19^{\circ} 55.56^{\prime} \mathrm{N}, 75^{\circ} 8.34^{\prime} \mathrm{W}\right)$ & $\mathrm{C}$ & Sig & 2 & GTMO unpub. data & \\
\hline $1 \mathrm{Jul} 2007$ & $\begin{array}{c}\text { South of Buoy 6, } \\
\text { GTMO }\end{array}$ & $\left(19^{\circ} 55.29^{\prime} \mathrm{N}, 75^{\circ} 9.65^{\prime} \mathrm{W}\right)$ & $\mathrm{C}$ & Sig & 1 & GTMO unpub. data & \\
\hline 6 Jul 2007 & $\begin{array}{l}\text { Near St. Nicholas } \\
\text { Point, GTMO }\end{array}$ & N/A & $\mathrm{C}$ & Sig & 1 & GTMO unpub. data & \\
\hline 14 Jul 2007 & $\begin{array}{c}\text { Near Hospital Cay, } \\
\text { GTMO }\end{array}$ & $\left(19^{\circ} 56.77^{\prime} \mathrm{N}, 75^{\circ} 8.67^{\prime} \mathrm{W}\right)$ & $\mathrm{C}$ & Sig & 2 & GTMO unpub. data & \\
\hline 17 Jul 2007 & $\begin{array}{c}\text { Outside St. Nicholas } \\
\text { Channel, GTMO }\end{array}$ & N/A & $\mathrm{C}$ & Sig & 1 & GTMO unpub. data & \\
\hline 12 Aug 2007 & $\begin{array}{c}\text { St. Nicholas } \\
\text { Channel, GTMO }\end{array}$ & $\left(19^{\circ} 54.38^{\prime} \mathrm{N}, 75^{\circ} 11.50^{\prime} \mathrm{W}\right)$ & $\mathrm{C}$ & Sig & 1 & GTMO unpub. data & \\
\hline 5 Sept 2007 & $\begin{array}{c}\text { Between Buoy } 3 \text { and } \\
\text { 4, GTMO }\end{array}$ & $\left(19^{\circ} 54.89^{\prime} \mathrm{N}, 75^{\circ} 10.75^{\prime} \mathrm{W}\right)$ & $\mathrm{C}$ & Sig & 1 & GTMO unpub. data & \\
\hline 11 Sept 2007 & $\begin{array}{c}\text { St. Nicholas } \\
\text { Channel, GTMO }\end{array}$ & $\left(19^{\circ} 54.52^{\prime} \mathrm{N}, 75^{\circ} 11.30^{\prime} \mathrm{W}\right)$ & $\mathrm{C}$ & Sig & 1 & GTMO unpub. data & \\
\hline 8 Oct 2007 & $\begin{array}{c}\text { St. Nicholas } \\
\text { Channel, GTMO }\end{array}$ & $\left(19^{\circ} 54.70^{\prime} \mathrm{N}, 75^{\circ} 11.39^{\prime} \mathrm{W}\right)$ & $\mathrm{C}$ & Sig & 1 & GTMO unpub. data & \\
\hline 18 Oct 2007 & $\begin{array}{l}\text { Near St. Nicholas } \\
\text { Point, GTMO }\end{array}$ & $\mathrm{N} / \mathrm{A}$ & $\mathrm{C}$ & Sig & 1 & GTMO unpub. data & \\
\hline 21 Oct 2007 & $\begin{array}{c}\text { St. Nicholas } \\
\text { Channel, GTMO }\end{array}$ & $\left(19^{\circ} 54.47^{\prime} \mathrm{N}, 75^{\circ} 11.32^{\prime} \mathrm{W}\right)$ & $\mathrm{C}$ & Sig & 1 & GTMO unpub. data & \\
\hline 27 Oct 2007 & $\begin{array}{l}\text { Near Leeward Ferry } \\
\text { Landing, GTMO }\end{array}$ & $\left(19^{\circ} 54.62^{\prime} \mathrm{N}, 75^{\circ} 11.39^{\prime} \mathrm{W}\right)$ & $\mathrm{C}$ & Sig & 1 & GTMO unpub. data & \\
\hline
\end{tabular}




\begin{tabular}{|c|c|c|c|c|c|c|c|}
\hline Species/Date & Location & Position & Status $^{a}$ & Type $^{\mathrm{b}}$ & $\begin{array}{l}\text { Group } \\
\text { Size }\end{array}$ & Source $^{c}$ & Comments \\
\hline 27 Oct 2007 & $\begin{array}{c}\text { St. Nicholas } \\
\text { Channel, GTMO }\end{array}$ & $\left(19^{\circ} 54.58^{\prime} \mathrm{N}, 75^{\circ} 11.36^{\prime} \mathrm{W}\right)$ & C & Sig & 1 & GTMO unpub. data & \\
\hline 28 Oct 2007 & $\begin{array}{c}\text { Mouth of } \\
\text { Guantánamo River, } \\
\text { GTMO }\end{array}$ & $\left(19^{\circ} 54.58^{\prime} \mathrm{N}, 75^{\circ} 11.36^{\prime} \mathrm{W}\right)$ & $\mathrm{C}$ & Sig & 1 & GTMO unpub. data & \\
\hline 7 Nov 2007 & $\begin{array}{c}\text { Near Buoy 3, St. } \\
\text { Nicholas Channel, } \\
\text { GTMO }\end{array}$ & $\left(19^{\circ} 54.60^{\prime} \mathrm{N}, 75^{\circ} 11.40^{\prime} \mathrm{W}\right)$ & $\mathrm{C}$ & Sig & 1 & GTMO unpub. data & \\
\hline 24 Nov 2007 & $\begin{array}{c}\text { Santa Bargo, } \\
\text { GTMO }\end{array}$ & N/A & $\mathrm{C}$ & Sig & 1 & GTMO unpub. data & \\
\hline 3 Dec 2007 & $\begin{array}{c}\text { St. Nicholas } \\
\text { Channel, GTMO }\end{array}$ & $\left(19^{\circ} 54.41^{\prime} \mathrm{N}, 75^{\circ} 11.50^{\prime} \mathrm{W}\right)$ & $\mathrm{C}$ & Sig & 1 & GTMO unpub. data & \\
\hline 6 Dec 2007 & $\begin{array}{c}\text { St. Nicholas } \\
\text { Channel, GTMO }\end{array}$ & $\left(19^{\circ} 54.43^{\prime} \mathrm{N}, 75^{\circ} 11.45^{\prime} \mathrm{W}\right)$ & C & Sig & 1 & GTMO unpub. data & \\
\hline 10 Dec 2007 & $\begin{array}{c}\text { St. Nicholas } \\
\text { Channel, GTMO }\end{array}$ & $\left(19^{\circ} 54.38^{\prime} \mathrm{N}, 75^{\circ} 11.53^{\prime} \mathrm{W}\right)$ & $\mathrm{C}$ & Sig & 1 & GTMO unpub. data & \\
\hline 31 Dec 2007 & $\begin{array}{c}\text { MWR Marina, } \\
\text { GTMO }\end{array}$ & $\left(19^{\circ} 55.56^{\prime} \mathrm{N}, 75^{\circ} 8.34^{\prime} \mathrm{W}\right)$ & $\mathrm{C}$ & Sig & 1 & GTMO unpub. data & \\
\hline $6 \operatorname{Jan} 2008$ & HD9, GTMO & N/A & $\mathrm{C}$ & Sig & 1 & GTMO unpub. data & \\
\hline 9 Jan 2008 & $\begin{array}{c}\text { Fisherman's Point, } \\
\text { GTMO }\end{array}$ & $\left(19^{\circ} 55.10^{\prime} \mathrm{N}, 75^{\circ} 9.44^{\prime} \mathrm{W}\right)$ & $\mathrm{C}$ & Sig & 1 & GTMO unpub. data & \\
\hline 9 Jan 2008 & $\begin{array}{c}\text { Mouth of } \\
\text { Guantánamo River, } \\
\text { GTMO }\end{array}$ & $\left(19^{\circ} 54.71^{\prime} \mathrm{N}, 75^{\circ} 11.71^{\prime} \mathrm{W}\right)$ & $\mathrm{C}$ & Sig & 1 & GTMO unpub. data & \\
\hline 13 Jan 2008 & $\begin{array}{c}\text { St. Nicholas } \\
\text { Channel, GTMO }\end{array}$ & $\left(19^{\circ} 54.50^{\prime} \mathrm{N}, 75^{\circ} 11.37^{\prime} \mathrm{W}\right)$ & $\mathrm{C}$ & Sig & 1 & GTMO unpub. data & \\
\hline
\end{tabular}

\begin{tabular}{|c|c|c|c|c|c|c|c|}
\hline \multicolumn{8}{|c|}{ PINNIPEDIA } \\
\hline \multicolumn{8}{|c|}{ Monachus tropicalis } \\
\hline ca. 1520 & Arrecifés Viboras & $\left(21^{\circ} 40^{\prime} \mathrm{N}, 79^{\circ} 57^{\prime} \mathrm{W}\right)$ & $P$ & Cap & N/A & $\begin{array}{l}\text { Díaz Del Castillo } \\
\text { (1912) }\end{array}$ & \\
\hline $\begin{array}{c}1877-1878 \\
\text { (winter) }\end{array}$ & Isla de Juventud & $\left(22^{\circ} 08^{\prime} \mathrm{N}, 82^{\circ} 29^{\prime} \mathrm{W}\right)$ & $\mathrm{C}$ & Cap & N/A & Allen (1880) & \\
\hline 1883 & Habana & $\left(23^{\circ} 08^{\prime} \mathrm{N}, 82^{\circ} 22^{\prime} \mathrm{W}\right)$ & $\mathrm{C}$ & Cap & 1 & $\begin{array}{c}\text { Allen (1887); Elliott } \\
\text { (1884) }\end{array}$ & \\
\hline 1930s & Baracoa & $\left(20^{\circ} 21^{\prime} \mathrm{N}, 74^{\circ} 30^{\prime} \mathrm{W}\right)$ & $\mathrm{C}$ & Sig & N/A & Campbell (1978) & \\
\hline $1930 \mathrm{~s}$ & Santiago & $\left(20^{\circ} 00^{\prime} \mathrm{N}, 75^{\circ} 51^{\prime} \mathrm{W}\right)$ & $\mathrm{C}$ & Sig & N/A & Campbell (1978) & \\
\hline \multicolumn{8}{|c|}{ Unidentified pinniped } \\
\hline 1987 & $\begin{array}{l}\text { Off southern coast } \\
\text { of Cuba }\end{array}$ & N/A & $\mathrm{C}$ & Sig & 1 & $\begin{array}{l}\text { Mignucci-Giannoni } \\
\text { and Odell (2001) }\end{array}$ & Possible hooded seal \\
\hline
\end{tabular}

\section{Units are abbreviated:}

meter $(\mathrm{m})$, centimeter $(\mathrm{cm})$, circa $(\mathrm{ca}$.

\section{Other abbreviations}

N/A - information not available;

POP - Pelagic Observer Program;

GTMO - U.S. Naval Station Guantánamo Bay;

USNM - Smithsonian Institution National Museum of Natural History

(United States National Museum), Washington, D.C.

astatus/verification of record: $\mathrm{C}=$ Confirmed; $\mathrm{P}=$ Possible; $\mathrm{D}=$ Doubtful

${ }^{\text {b}}$ Type of record: Sig=Sighting; Str=Stranding; Cap=Capture; Det=Tagging Detection. Note that all osteological records are listed as strandings, and captures include bycatch and whaling records.

'Only primary sources are listed for each record. Secondary sources are also included if they contain specific information that was not included in the primary source or if the primary source could not be found.

${ }^{\mathrm{d} G u i t a r t, ~ D ., ~ A c a d e m i a ~ d e ~ C i e n c i a s ~ T e c n o l o g i ́ a ~ y ~ M e d i o ~ A m b i e n t e ~ d e ~ C u b a, ~}$ pers. comm., 1998 and May 2005.

${ }^{e}$ Carrillo, E. and Echemendía J., La Cooperativa de Pesca Caibarien Villa Clara, pers. comm., July 1997.

${ }^{f}$ Cuba news from Radio Havana Cuba. Humpback whale dies off Cuban coast. Accessed 26 April 2008. http://www.radiohc.org/Distributions/ Radio_Havana_English/.1999/99_jan/rhc-eng-01.20.99.

${ }^{g}$ Díaz Fernández, R., Centro de Investigaciones Marinas, Universidad de la Habana, pers. comm., 7 August 2006.
hCuba news from Radio Havana Cuba. Whales spotted on Cuba's southern coast. Accessed 8 November 2008. http://www.radiohc.org/

Distributions/Radio_Havana_English/.2000/2000_jun/Radio_Havana_ Cuba-19_June_2000_22:00.

'González, O., Ministerio de Ciencia Tecnología y Medio Ambiente (CITMA) de Cayo Coco, pers. comm., August 2002.

iYánez, A., Patrón del Catamarán de Turismo DODY, pers. comm., February 2005.

${ }^{k}$ Moreno, F. and Carvajal, A., Patrón y Maquinista del Yate de Turismo Marlin, pers. comm., April 2006.

'Ballenas frente a las costas de Baracoa. 201 Lecturas by Soler Costafreda, A. Accessed 13 March 2008. www.portal.jovenclub.cu.

${ }^{\mathrm{m}}$ Varona (1965) initially reported this specimen as a sei whale; Mead (1977) later determined it to be a Bryde's whale based on descriptions of the rostrum and close examination of the baleen.

"Soberat, A., Acuario de Baconao, Santiago de Cuba, pers. comm., 1997.

'Lauranzon Meléndez, B., Museo de Historia Natural de Santiago de Cuba, pers. comm., 29 April 2009.

PCárdenas, J., Patrón del Velero Ying Yang de Puerto Sol, pers. comm., April 2002.

qViña, N. and Tamayo, J.A., Centro Oriental de Ecosistemas y Biodiversidad (BIOECO), pers. comm., February 2006.

'Kenney, R., University of Rhode Island, pers. comm., 22 July 2009.

sTamaño, J.A., Centro de Biodivercidad de Ecosistemas Costeros de la zona Oriental de Cuba, pers. comm., February 2004. 
'Romero, S., Acuario de Baconao, Santiago de Cuba, pers. comm., September 2007

"Anido, T., Academia de Ciencias Tecnología y Medio Ambiente de la Isla de la Juventud, pers. comm., December 2006.

"Romero, Z., Acuario de Baconao, Santiago de Cuba, pers. comm., 2006 and 2007.

"Data were geo-referenced from the discernible sightings in the figures included in Pérez-Cao (2004) and Alvarez Alemán et al. (2009) since exact coordinates of these records were not available. No exact dates or group sizes could be matched to these records.
Echemendía J., La Cooperativa de Pesca Caibarien Villa Clara, pers. comm., 2006.

${ }^{y}$ Guevara, C., Acuario Nacional de Cuba, pers. comm., 2004.

${ }^{z}$ Martínez, E., Patrón de la embarcacion Veneciana II de la Marina de Tarara, Habana, pers. comm., 2005.

${ }^{a 1}$ Isla, V., Acuario Nacional de Cuba, pers. comm., 2008

${ }^{b 1}$ Rivera, J., Mundo Latino, Habana, pers. comm., 2008.

${ }^{\mathrm{c}}$ Title of article incorrectly refers to pilot whales but the body of the article discusses "Grampus griseus". This record is discussed further in the text.

d1Sánchez, L., Acuario Nacional de Cuba, pers. comm., 1997. 